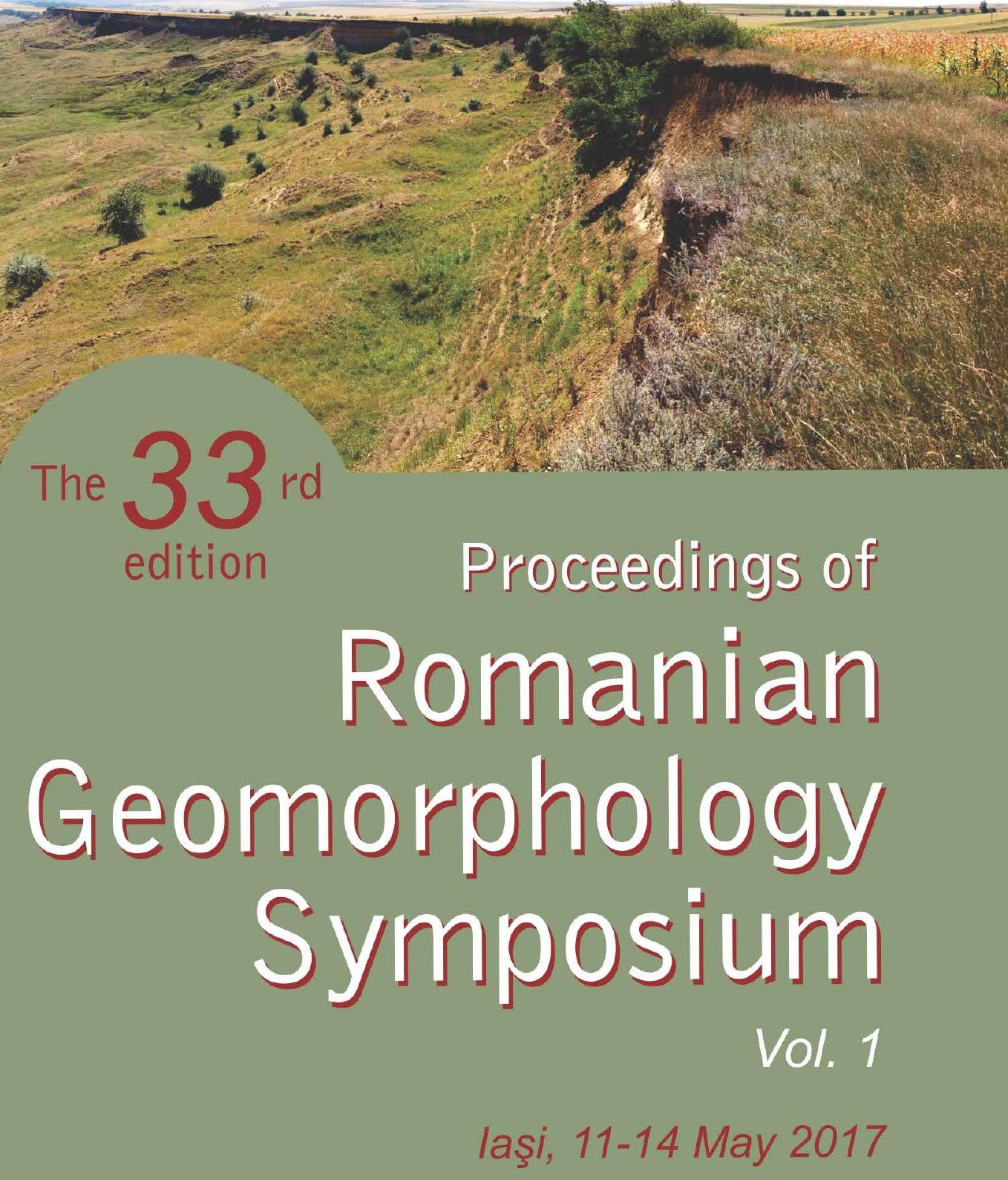

Edited by:

MIHAI NICULITǍ

MIHAI CIPRIAN MǍRGĂRINT

EDITURA UNIVERSITĂTII „ALEXANDRU IOAN CUZA” DIN IAŞI 


\title{
Proceedings of the Romanian Geomorphology Symposium
}

33rd edition, Iaşi, 11-14 May 2017

\author{
Edited by: \\ Mihai NICULIȚĂ \\ Mihai Ciprian MĂRGĂRINT
}

EDITURA UNIVERSITĂȚII “ALEXANDRU IOAN CUZA” DIN IAȘI 
Scientific committee:

Maria RĂDOANE, ,Ştefan cel Mare” University of Suceava;

Petru URDEA, West University of Timişoara; Alfred VESPREMEANU-STROE, University of Bucharest;

Dan DUMITRIU, „Alexandru Ioan Cuza” University of Iaşi;

Mihai MICU, Institute of Geography, Romanian Academy, Bucharest;

Olimpiu POP, „Babeş-Bolyai” University, Cluj-Napoca;

Sandu BOENGIU, University of Craiova;

Francisca CHIRILOAEI, „Ştefan cel Mare” University of Suceava;

Mircea VOICULESCU, West University of Timişoara;

Marta JURCHESCU, Institute of Geography, Romanian Academy, Bucharest;

Nicolae CRUCERU, „Spiru Haret” University, Institute of Speology "Emil Racoviță", Bucharest;

Robert DOBRE, University of Bucharest;

Mihai Ciprian MĂRGĂRINT, „Alexandru Ioan Cuza” University of Iaşi;

Mihai NICULIȚă, „Alexandru Ioan Cuza” University of Iaşi.

\section{Organizing committee:}

Mihai Ciprian MĂRGĂRINT, „Alexandru Ioan Cuza” University of Iaşi;

Mihai NICULIȚĂ, „Alexandru Ioan Cuza” University of Iaşi;

Corneliu IAȚU, „Alexandru Ioan Cuza” University of Iaşi;

Adrian GROZAVU, „Alexandru Ioan Cuza” University of Iaşi;

Doru Toader JURAVLE, „Alexandru Ioan Cuza” University of Iaşi;

Silviu DORU, „Alexandru Ioan Cuza” University of Iaşi; Ioana DICU, „Alexandru Ioan Cuza” University of Iaşi; Nicuşor NECULA, „Alexandru Ioan Cuza” University of Iaşi;

Denisa Cecilia NICU, „Alexandru Ioan Cuza” University of Iaşi. 


\section{Contents}

\section{Part I: Introduction, Peoples and Places}

Romanian Association of Geomorphologists - evolution of an idea

Maria Rădoane

“Mihai Eminescu” Central University Library of Iași - short presentation

Alina Frunză

Part II: Papers

Geomorphological facilities and constraints in urban expansion of Craiova city

Claudia-Daniela Albă, Oana Mititelu-Ionuş and Sandu Boengiu

Identifying ground displacement trends in Bucharest using InSAR

Iuliana Armaş, Diana Mendes, Răzvan-Gabriel Popa, Mihaela Gheorghe and Diana Popovici

Geomorphic services for landslide risk evaluation in the RO-RISK Project

Dan Bălteanu, Marta Jurchescu, Mihaela Sima, Mihai Micu and Gheorghe Kucsicsa

Landslide inventory of the Crasna catchment, Moldavian Plateau, Romania

Alina Bejenaru and Mihai Niculiţă

The Oprăneşti landslide (Mehedinţi County) - evaluation, impact, solutions

Sandu Boengiu, Daniel Simulescu, Oana Mititelu-Ionuş and Claudia Albă

Monitoring and segmentation of 10 caves from the Pădurea Craiului Mountains in order to ensure

conservative management. Case study: Ciur Ponor Cave

Nicolae Cruceru, Alexandru Petculescu, Rodica Plăiașu, Ioana Meleg, Augustin Nae, Cristian-Mihai Munteanu, Luchiana Faur, Daniela Cociuba (Borda), Eugen Nițu, Marius Vlaicu and Marius Robu

Relief suitability for Ploiești - Pașcani fast road construction

Robert Dobre

Early warning intelligent system for road transportation risks

Robert Dobre, Laurențiu Ilie, Ionuț Săvulescu and Mădălina Teodor

The role of human activities in streambank stability: Lower Sakarya River (NW Turkey)

Umit Duru

The glacial buzzsaw and its limitations: mountain glaciation in British Columbia and in Britain

Ian Evans

Karstification in the mountains Durmitor (Montenegro) and Pirin (Bulgaria) and its

expression in surface landforms

Emil Gachev and Ilia Mitkov

Spatial distribution and controlling factors of snow avalanche

and debris flow in Parâng Mountains .53

Ionela Gavrilă, Olimpiu Pop, Csaba Horvath, Flaviu Meseșan and Iulian Holobâcă 
The dynamics of the Danube channel over the last 150 years (Giurgiu - Călărași sector. Preliminary data) ........56 Florina Grecu, Ştefania Grigorie, Gabriela Ioana-Toroimac and Cristina Ghiță

Burial dating of fluvial terraces using cosmogenic nuclides, Arieş River

Maria Hosu, Delia M. Gheorghiu and Sheng $\mathrm{Xu}$

Sediment dynamics and channel adjustments following a torrential flood in a small catchment:

Gemenea, Eastern Carpathians

Florentina Livarciuc, Maria Rădoane and Adrian Chelariu Moroșan

Effective development by relief suitability and transport infrastructure of the Obârșia Lotrului ski area

Laurenţiu Ilie, Laura Comănescu, Robert Dobre and Mădălina Teodor

Geomorphologic regionalising of the Romanian territory in the space-chronologic system context

Octavian Mândruț

The use of satellite images in the morphological analysis of the Siret riverbed between

Cosmești and Galați

Diana Alexandra Marola and Laura Comănescu

Dendrogeomorphogical assessment of snow avalanche activity in Parâng Mountains .75

Flaviu Meseșan, Olimpiu Pop, Ionela Gavrilă and Cosmin Timofte

Certain and potential earthquake-induced landslides in Vrancea seismic region

Mihai Micu, Hans-Balder Havenith, Dan Bălteanu, Alexandru Onaca, Anne-Sophie Mreyen and Carmen Cioflan

The landslide database of North-Eastern Romania

Mihai Niculiţă, Andrei Adrian and Cristina Lupu

InSAR analysis of Sentinel-1 data for monitoring landslide displacement of the north-eastern Copou hillslope, Iaşi city, Romania

Nicuşor Necula, Mihai Niculiţă, Mario Floris and Giulia Tessari

Tree-ring based reconstruction of snow avalanche frequency in Şureanu Mountains

(Southern Carpathians, Romania)

Olimpiu Traian Pop, Flaviu Mesesan, Ionela-Georgiana Gavrila and Cosmin Timofte

History of Holocene fluvial activity in Romania: evidences based

on absolute dating

Maria Rădoane, Ioana Perșoiu, Francisca Chiriloaei, Constantin Nechita, Delia Robu and Nicolae Rădoane

The evolution of the area between Valea Chinteni and Valea Calda after the works done so as to prevent the soil erosion

Violeta-Elena Retegan

Coastal storms risk assessment for Mamaia and Eforie barriers

Mădălina Ristea and Florin Tătui

Geomorphological evolution of coastal landslides in Malta: integration of terrestrial and marine datasets

Mauro Soldati, Mariacristina Prampolini and Vittoria Vandelli

The geomorphology of humanity

Paolo Tarolli

Danube Delta coastline dynamics in the last 160 years

Florin Tătui, Alfred Vespremeanu-Stroe, Florin Zăinescu and Ștefan Constantinescu

Creating an analysis model in order to identify solutions for sustainable development of ski areas in Romania ...110 
Mădălina Teodor, Robert Dobre, Laurențiu Ilie and Gabriel Stănoiu

Cave morphology provides evidence of polyphase tectonics - an example from the

Isverna karst system, South Carpathians

Laura Tîrlă, Virgil Drăguşin, Marius Vlaicu, Ionuț Mirea, Daniela Dimofte and Relu-Dumitru Roban

Considerations regarding the dynamic of the present geomorphological processes developed

on the sector of subsequent valley of the Prut river between the localities Horodiştea (Romania)

and Criva (Republic of Moldova)

Georgiana Văculişteanu and Alin Prisacariu

An approach to investigate the effects of climate change on landslide hazard at a national scale (Romania)

Marta Jurchescu, Dana Micu, Mihaela Sima, Dan Bălteanu, Roxana Bojariu, Alexandru Dumitrescu, Carmen Dragotă, Mihai Micu and Francisc Senzaconi

\section{Part III: Fieldtrips}

Hadâmbu sector of Iași cuesta escarpment - recent mass movement processes and deforestation

Mihai Ciprian Mărgărint, Mihai Niculiță and Silviu Doru

Relict landslides, fluvial landforms and threatened geoheritage - Costești village

Mihai Niculiță, Mihai Ciprian Mărgărint and Ionuț Cristea

Relict landslides, gullies and geoheritage sites -Băiceni village

Mihai Niculiță, Mihai Ciprian Mărgărint and Ionuț Cristea

Old anthropic dams, lacustrine deposits, and gullies from Șoldănești village

Mihai Ciprian Mărgărint, Mihai Niculiță, Silviu Doru, Nicuşor Necula and Ionuț Cristea

Degraded agricultural terraces, landslides and gullies from Libertatea village ...

Mihai Niculiță and Mihai Ciprian Mărgărint

Berza - Santa Mare complex landslide

Mihai Niculiță and Mihai Ciprian Mărgărint

Annex: Fieldtrips map 

Part I - Introduction: Peoples and Places 



\title{
Romanian Association of Geomorphologists - evolution of an idea
}

\author{
Maria Rădoane \\ President of Romanian Association of Geomorphologists \\ Ştefan cel Mare University of Suceava \\ Suceava, Romania \\ radoane@usm.ro
}

Well-known geographers such as T. Morariu, V. Mihăilescu, V. Tufescu, N. Al. Rădulescu, P. Coteț, C. Martiniuc, V. Băcăoanu, N. Popp have marked the evolution of geomorphology in Romania and are the ones that gave rise to the idea of forming a group with common preoccupations for the landform study since 1967 [1]. More than fifty years have passed since the publication of the monumental work, "Monografia geografică” (1960), coordinated by two geomorphologists (P. Cotet and C. Martiniuc). The exchange of ideas and information with European geomorphology leaders has become increasingly active after 1965, and so, the desire to focus the efforts of the geomorphology experts on common objectives was shaped more pronouncedly. Grigore Posea, supported by colleagues was the one who put this idea in practice, at the first National Symposium of Geomorphology held in Brassov, in June 1972. The topic of symposium was "Romania's achievements in the landscape study over the last 25 years" which spurred further research on the large relief units. Nor well past a year, that in 1973 no further than a year later, in 1973, the volume "Realizări în geografia românească”, a collection of valuable theoretical studies, synthesizing the issue of relief in Romania, was published. Still today remains a reference work for the relief of Romania.

This brief evocation of the early organization of geomorphology as working group, draws attention on the strong influence of the scientific personalities and on the geomorphology schools of that time, responsible, in my opinion, also, for the prolificacy of publications and ideas, many of them still valid today. No wonder that the geomorphology symposia organized yearly, without interruptions, were real events with debates and confrontations (sometimes bluntly) among opinion leaders on: glaciation problem in Carpathians, periglacial in Romania, river valleys evolution, fluvial terraces, denudation surfaces, etc. Sharp confrontations, reaching even enmity, took place on issues that today seem irrelevant, like the boundaries between major relief units.

Political freedoms obtained after December 1989 brought the legal foundation of the Romanian Association of Geomorphologists, who gain its legal status on 6 April, 1990. The founders (universitarians, researchers, geography teachers, experts from other domains, interested in landform knowing) gathered at the Faculty of Geography, Bucharest and the first president in the person of Professor Grigore Posea was elected. On that occasion, the leadership, the first president and vice-presidents: Ioan Mac, Dan Bălteanu, Ioniţă Ichim were designated. In the same year, the association obtained legal personality (foundation documents were published in Revista de Geomorfologie, no.1, 1997) [2].

We appreciate that the moment of RAG constitution took place less than one year after the foundation of International Association of Geomorphologists (IAG/AIG), respectively, 1989, when the second International Conference on Geomorphology (Frankfurt/Main, Germany) was organized. Romanian Association of Geomorphology (RAG) adhered at IAG/AIG in 1997, joining 61 geomorphology professional associations from the same number of countries.

Yearly and sometimes biannual, the Romanian geomorphologists (RAG affiliated or no) have gathered during Symposia. Two pictures are suggestive to portray the geomorphologist group that marked those early decades of our association (Figs 1 and 2).

During their annual and biannual Symposium meetings the Romanian geomorphologist discussed key issues of the relief in Romania, concepts and research methods and even challenges from other domains with interest on landforms. The list of Symposiums that took place over time is presented on www.geomorfologie.ro. The map (Fig. 3) shows the spatial distribution of localities were the RAG symposia were organized and at the same time illustrates the development, the tradition and the strength of the group of geomorphologists in Romania. As detailed information is not available (for example, the programs of all these manifestations) we weren't able to perform an analysis regarding the evolution of the addressed subjects. One of the oldest programs found in the archives of colleagues was the one from the 1993 symposium. By comparing the topics with the ones from 2013 (20 years later) we have found a pretty broad change regarding the dynamic of topics and of framing in the big domains of geomorphology, historicist (preoccupied by palaeoevolution) and functional (preoccupied by understanding the modeling processes). 


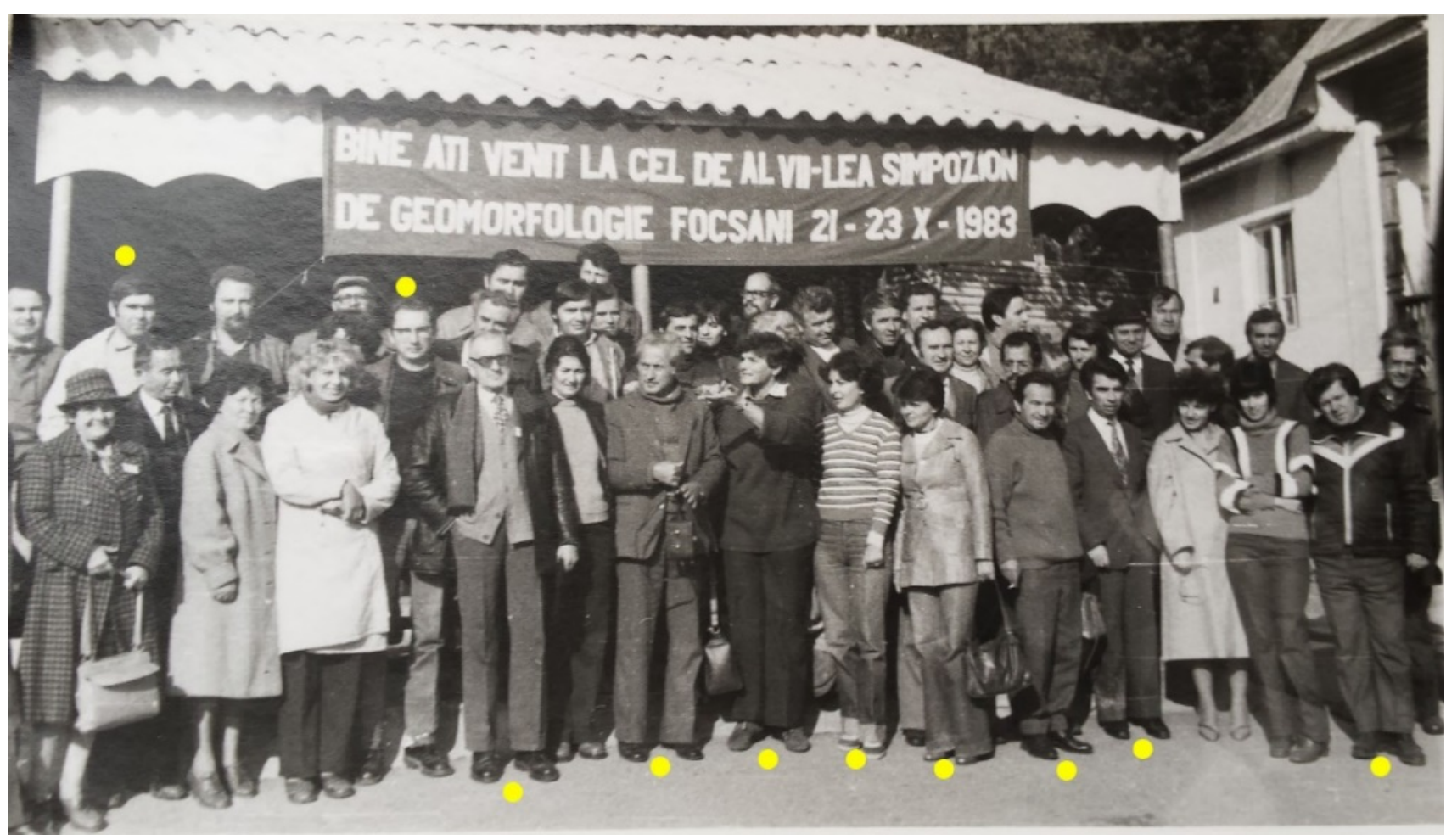

Fig. 1. Participants to the Seventh National Symposium of Geomorphology, Focșani, 1983. From left to right following the yellow dot: Dan Bălteanu, Emil Vespremeanu, Nicolae Popp, Grigore Posea, Maria Pătroescu, Mihaela Dinu, Maria Sandu, Nicolae Popescu, Ioniță Ichim, Mihai Ielenicz.

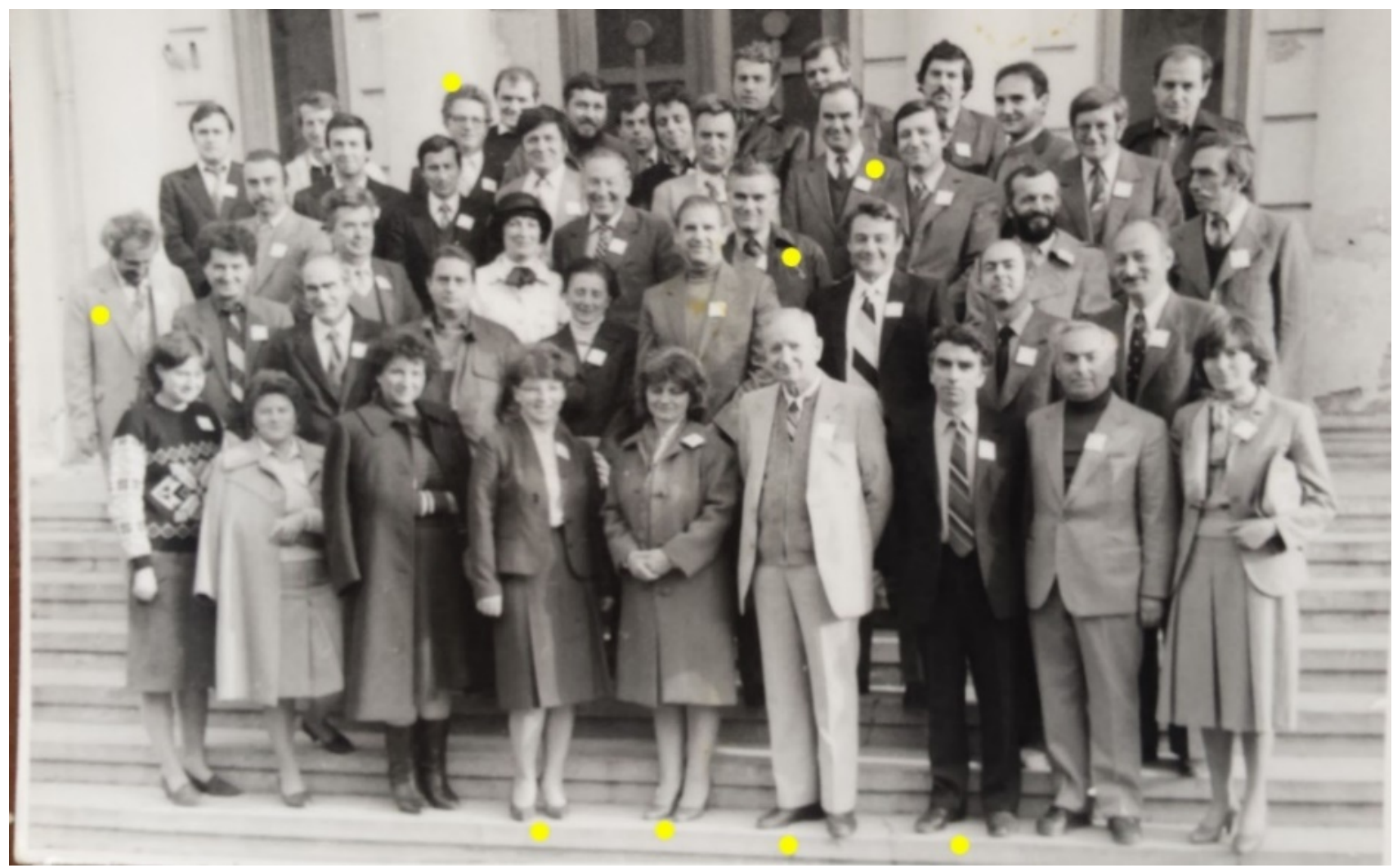

Fig. 2. Participants to the Provenance and sediment delivery symposium, Piatra Neamț, 1986. From left to right by following the yellow dot, above: Virgil Surdeanu, Nicolae Rădoane, Ioan Mac, Ion Zăvoianu. Idem, down: Maria Rădoane, Florina Grecu, Constantin Martiniuc, Ioniță Ichim

In 1993 the historicist subjects counted about $70 \%$ of the geomorphologists preoccupation, while in 2013, only about 5\%. As we will show below, it was a natural phenomenon, in perfect sync with international trends in geomorphology evolution. 
After year 1990, 9 presidents have succeeded, in the lead of RAG: Grigore Posea (University of București); Ioan Mac (University Babeș-Bolyai Cluj-Napoca), Nicolae Popescu (University of București), Emil Vespremeanu (University of București), Nicolae Josan (University of Oradea), Virgil Surdeanu (University Babeș-Bolyai ClujNapoca), Petru Urdea (West University of Timişoara), Maria Rădoane (University Ștefan cel Mare of Suceava). From this presentation can be noted an interesting spatial distribution, sign that the geomorphological research centers have claimed both large universities and also the medium size ones.

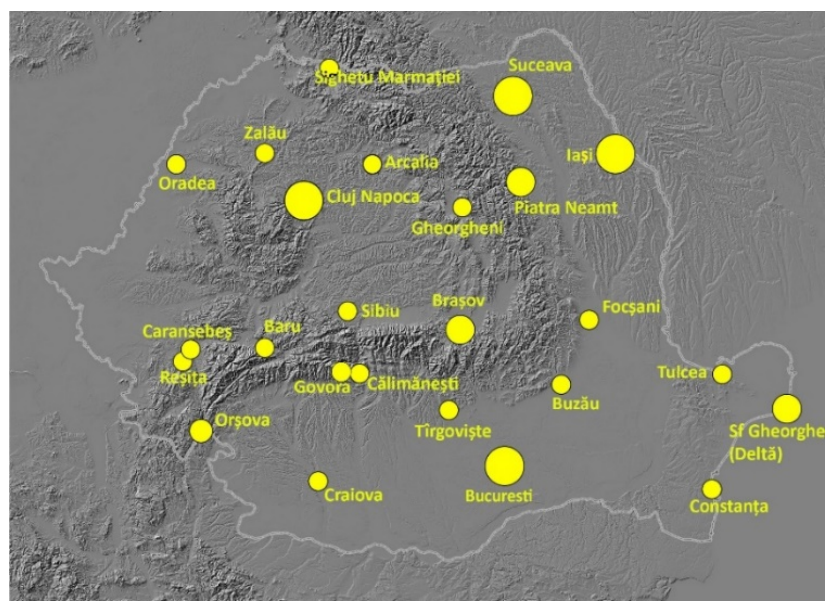

Fig. 3. Spatial distribution of the localities where the National Symposium of Geomorphology was organized, from 1972 until present. At Iași, Cluj, București and Suceava were organized at least 3 symposia, at Brașov, Piatra Neamț, Orşova and Sf.Gheorghe (Danube Delta) 2 symposia, in the rest of the localities on the map, 1 symposium.

From 1990, RAG is editing the Revista de Geomorfologie Journal (www.revistadegeomorfologie.ro) which reached no. 18. Following the same line as the research topics presented at the symposia, the content of Revista de Geomorfologie Journal from 1990 until present reflects the perfect synchronization of the theoretical concepts and research methods with those manifested at international context [3]. It seems very relevant to recall a passage from an article by [4] to illustrate the importance of contacts and relations at international level, the connection of Romanian geomorphology to the trends and preoccupations presented in international context needed to elaborate our own analysis models in the landform domain. Despite many difficulties to direct access the international scientific events before 1990, Romanian presence at the high meetings of the international geomorphological community (as it was the first International Conference of Geomorphologists, Manchester, 1985) was reported, and some evidences of this are impressive. We present below a passage of the article mentioned above, published in Terra Journal, from which we conclude that Romanian geomorphologists had the same scientific concerns as their international counterparts, but less support in what regards the logistical aspects of their work:

" Because the title of this article (Geomorphology in the 3rd Millennium threshold, n.n.) it may seem strange to most, I want to start with the confession that it plagued me for nearly a decade. Not only expression itself, but rather, the actual coverage of the history of our science and its path. It has happened that after my participation at the first International Geomorphology Conference (Manchester, 1985) when I saw the largest exhibition of books and journals from world in the domain, and numerous exhibitions of equipment and technology work, included those presented by NASA have constituted without any doubt, unimaginable performances. And as a corollary of these unique premieres for the most of geomorphologists, to works developed under NASA management were discussed by all audience, before being published in a final form: Geomorphology from space - A global overview of regional landforms (eds. N. M. Short and R.W. Blair Jr) and Global Mega-Geomorphology (ed. R.S. Hayden). The fact that NASA «entered» on the land of geomorphology was undoubtedly a sigh that our domain is located at a turning point". The same feeling somewhat overwhelming I had myself when I met the way in which EGU General Assembly is organized, back in 2008.

Not all the topics of geomorphology enjoyed the same trend overtime. For example, the domain of hillslopes frequently draw attention of the Romanian geomorphologists before 1989 who wanted to understand the relation between slope, deposits and processes. Before 1990, the hillslope morphological category passed in the background, and the hillslope processes under the name of hazards have become the focus of geomorphological investigations. Other domains (fluvial, coastal, periglacial, soil erosion) have experienced a remarkable transformation in terms of research methodology, with substantial conclusions based on measured and quantified data. Noteworthy is the increased preoccupation after year 2000 in geomorphological palaeoenvironments reconstruction from Early Quaternary by developing the absolute dating techniques. In addition, new domains like geomorphometry, have developed in Romania, due to the development of information technology.

In conclusion, the main qualitative thresholds in landform knowledge were crossed also by the Romanian geomorphologists due to: "the quantitative revolution", the focus on the study of the geomorphological processes and landform dynamics at medium and small scales, the access to the latest technologies needed for observations and measurements on processes and landforms, and to the access to absolute dating which allows the reinterpretation of the landform evolution on a larger temporal scale. All these have supported the affirmation of a group of young geomorphologists with interdisciplinary education and excellent analytical skills which forms today the most prolific part of our association in what regards scientific results. An illustration of this is the recent publication of the Landform Dynamics and Evolution in Romania (edited by M. Rădoane and A. Vespremeanu-Stroe), Springer, 2016.

\section{REFERENCES}

[1] E. Vespremeanu, “40 ani de geomorfologie organizată în România”, Revista de Geomorfologie, vol. 7, pp. 5-7, 2005. (in Romanian)

[2] G. Posea, "Cuvânt inainte”, Revista de Geomorfologie, vol. 1, no. pp. 1-2, 1997. (in Romanian) 
[3] M. Rădoane, A. Vespremeanu-Stroe, "Introduction” in Landform Dynamics and Evolution in Romania, M. Rădoane, A. Vespremeanu-Stroe, Eds. Springer, 2017, pp. 1-11.
[4] I. Ichim, "Geomorfologia in pragul Mileniului III”, Terra, vol. 25, no. 1-4, pp. 83-90, 1993. (in Romanian) 


\title{
“Mihai Eminescu” Central University Library of Iaşi - short presentation
}

\author{
Alina Frunză \\ Faculty of History \\ Alexandru Ioan Cuza University of Iaşi \\ Iaşi, Romania \\ frunza_alina7@yahoo.com
}

\begin{abstract}
Mihai Eminescu” Central University Library of Iași is the oldest institution of its kind in the country and one of the most important Romanian academic and research libraries. In the present times, it is both an encyclopedic academic library and a research encyclopedic one offering to our readers (in home lending or only in a reading room consultation, depending on the case) its entire stock. Also, as an institution of national level importance, it contributes to the enrichment of the national heritage and ensures the preservation of the cultural memory in order to be known and make a capital out of it by the next generations.
\end{abstract}

Summing funds that were part of the former libraries of the Princely Academies (the oldest from 1640 and functioning at the Trei Ierarhi Monastery), the nowadays "Mihai Eminescu" Central University Library of Iași enjoys continuity and stability since 1835 as Library of the Mihăileană Academy, in time having changed only its name: University Library, "Ulpia” Library, Central Library. In 1860, with the foundation of the first university in the country at Iași, from library of the Mihăileana Academy it becomes a University Library, then Central and Public Library in 1864 and again a University one in 1916 [1]. It worked in the Mihăileană Academy building (today destroyed, between 1835 and 1860), in the old University (current University of Medicine and Pharmacy, until 1897), in the new University (now the study room of the "Gh. Asachi" Technical University Library), only to move after the 2nd World War (September 1st, 1945) in the building of the "King Ferdinand 1" Foundation Library, whose funds it includes.

The Iaşi University Library was a historical witness with an exceptional testimony vocation, as evidenced by the central edifice, which owes its existence to an exemplary initiative.

The central building is built according to the plans of the architect Constantin Iotzu [2], under the guidance of the engineered Emil Prager (who also raised the Royal Palace in Bucharest), being an outstanding architectural ensemble through the concept of space exploitation in accordance with the requirements of a reference cultural center in the architectural landscape of Iași. The interior of this edifice is finished with Carrara marble and Venetian mosaic and the exterior is adorned with impressive columns of ionic style, non-rustic pillars, small triangular fronts and medallions with remarkable personalities of national culture.
The founding act of the former "King Ferdinand I" Foundation dates back to February 27 1927, expressing the will of His Majesty King Ferdinand, at the request of the "University Foundation King Ferdinand I", through the voice of I. C. Brătianu, at the time the President of the Council of Ministers [2]. The Palace of the Foundation is King Ferdinand's wish to equip his war capital, Iași, with an edifice similar to the one his uncle initiated in the country's great capital, in memory of the hard times of the war for national unity, when the royal family took refuge in Iaşi. The actual construction works began in 1930, three years after the death of King Ferdinand, and their completion was due to the successor to the throne, King Carol II.

At present, the "Mihai Eminescu" Central University Library represents an important component of the cultural life of Iași and houses over 2.5 million bibliographic units, including books, periodicals, musical scores, manuscripts, cartographic materials, electronic resources, and so on. The inestimable manuscripts, incunabula, old and rare books, some of which bear illustrious signatures (B.P. Haşdeu, Mihai Eminescu - who were also directors of the institurion, Ion Creangă, Ștefan Procopiu, etc.) come mainly from monasteries and private libraries (C. Hurmuzachi, B. P. Hasdeu, Mihail Sturdza, L. Steege, V. Adamachi, Titu Maiorescu, Paul Gore, Iorgu Iordan, etc.), which came into our patrimony according to the law through donations or purchases. Among the documents of great value for the collections of the library are the Byzantine manuscript "Evangelion" or "Evangelical Lectionary", dating back to the tenth century, "The Gospel of Learning", printed by Coresi at Brașov in 1580-1581, "Romanian Book of Learning” or "Varlaam's Homiliary" (the first rule of law of Moldova, printed in the time of Vasile Lupu), Iași, 1643, "The Handbook of Law" (rule of law of Matei Basarab), Târgoviște, 1652, "Lives of the Saints" of Dosoftei, Iași, 1682 [3].

The encyclopedic collections of the "Mihai Eminescu" Central University Library are kept in the warehouses of the central unit and in the 12 subsidiaries organized in the Service of the Exact Sciences Library (Physics and Chemistry Library, Geography-Geology Library, Biology Library, Mathematics Library, Mathematics Seminar Library, Computer Science Library), Service of Social Sciences Library (Library of Economic Sciences, Pedagogy - Psychology and Physical Education - Sport Library, Philosophy Library) and Humanities Library 
(Library of law, History Library and Letters Library). The library branches operate in the faculties of the "Alexandru Ioan Cuza" University of Iași, the material base and the human resource belonging to the CUL.

The activity of this institution is based on three main directions: collections, document processing and public access to the national/international info-documentary system, and the main missions of the library are the organization, processing, preservation and development of collections, offering diverse, consistent and quality services for readers, as well as the development of technical and material support necessary for the didactic and research activity of the Iaşi University community, with an extension to the national and international one. Mainly addressed to the academic community, the services provided by the "Mihai Eminescu" Central University Library include several reading and information areas: the Karl Kurt Klein European Documentation Center, multimedia center, the documentation center for special collections, reading rooms for students, researchers and teachers, German reading room, periodicals room, reading rooms in branch libraries.

Among the services provided to users, we include: consulting of publications, loans of publications, accessing our catalogs/databases, consulting the RoLiNeST catalog and scientific databases purchased by the library, online order/extension, reference services on demand, bibliographic research on demand, editing of bibliographic information and documentation tools, information assistance in bibliographic research, national and international interlibrary lending, user education for information culture, printing, scanning and photography of documents, individual study rooms, open reading room (the first of its kind in the national network of Central University Libraries), book exhibitions, hosting of cultural and scientific events in the library aula, guided visits to the CUL [4].

Scientific activity has been influenced over time by the momentary needs of the library. Currently, the CUL Iași is distinguished by an active participation in the national scientific life by organizing various professional meetings, communication sessions, Library Days, an opportunity to contribute both to the valorization of information from the collections of the library and to the implementation of some library science theories. Since 1993, the magazine "Biblos" appears on paper and then on electronic support, where librarians from the country and from the country, irrespective of the type of library in which they work, come with library and cultural information. Librarians participate with communications at national or international symposia and conferences, publish studies and articles in cultural, literary and specialized journals, participate in online or printed collective works, and in the editing of bibliographic instruments. The "Mihai Eminescu” Central University Library carries out research and development activities, according to Government Decision no. 551/2007.

In addition to specific and research activities, the "Mihai Eminescu" Central University Library organizes openings of visual arts exhibitions, conferences and other scientific events, book launces, cultural meetings, film screenings, charity activities and concerts performed by soloists of the "Moldova" Philharmonic of Iași, of the "George Enescu" National University of Arts and of the Iaşi National Romanian Opera.

The "Mihai Eminescu" Central University Library means tradition and continuity, an active information center, multilateral education and capitalization of a priceless documentary thesaurus. An important component of the Iași university life, the emblematic institution is integrated into European structures as a true information provider and mediator.

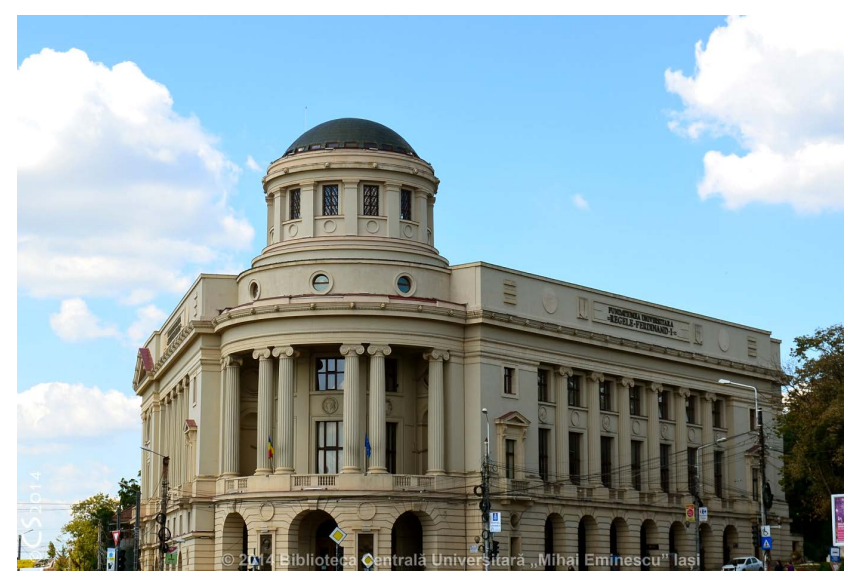

Fig. 1. The frontispiece of the CUL building seen from Mihai Eminescu Square.

\section{REFERENCES}

[1] Reveca Vitcu, Biblioteca Centrală Universitarădin Iași - repere ale continuității, în Biblioteca Universitară între tradiție și devenire, B.C.U. „Mihai Eminescu” Iași, 1988, p. 85. (in Romanian)

[2] Ioana Gafton, Înfiintarea Fundatiei Universitare Regele Ferdinand I și rolul ei în viața B.C.U. „Mihai Eminescu” Iași, „Almanahul Convorbiri Literare”, 2002, p. 88. (in Romanian)

[3] Nicoleta Popescu, Liviu Papuc, Radu Tătărucă, Biblioteca Centrală Universitară „Mihai Eminescu” - Iași. Monografie, Iași, 1989, p. 35. (in Romanian)

[4] http://www.bcu-iasi.ro/ - „,Services” branch. 
Part II - Papers 



\title{
Geomorphological facilities and constraints in urban expansion of Craiova city
}

\author{
Claudia-Daniela Albă, Oana Mititelu-Ionuş, Sandu Boengiu \\ Department of Geography \\ University of Craiova \\ Craiova, Romania
}

\begin{abstract}
Since the appearance of the first cities, the landforms have represented a prime determinant in urban establishment and expansion, materializing either in a favourable element (river valleys, depressions), or in a restrictive one (mountain slopes, lands affected by landslides, floods or earthquakes). The urban planning and expansion involve the use of urban geomorphology, thus requiring geological and geomorphological analyses of the land and the dynamics monitoring of natural and anthropic processes that occur.
\end{abstract}

This study presents the territorial expansion of the Craiova city area in the geomorphological context induced by the river Jiu land form, in the period $1977-2017$. The visual perspective of the territorial expansion dynamic is performed with ArcGIS10, using multi-temporal satellite images from databases such as Landsat, CLC Europe, Google and topographical maps. There are also presented the morphometric and morphographic analyses of territory synthesized in indicators and specific maps (hypsometry, declivity, aspect).

The review of the territorial expansion of the last 40 years, correlated with the study of propitious geomorphological elements, the constraints generated by nature and the interpretation of the geomorphological indicators, transposes in tools necessary for a more efficient development and planning of Craiova's urban space.

Keywords- urban geomorphology; urban expansion; Craiova

\section{INTRODUCTION}

"An understanding of geomorphology, the science of landforms and earth surface processes, is essential to urban development. People need to know the ground they build on and to be aware of risk of flooding, subsidence, landslide, volcanic activity, earthquakes and erosion” [1]. In 1976, R.U. Cooke considered that the two important ways in which urban geomorphology could be useful for the management and development of urban areas were: the assessing of the potential resources and the suitability of land use in urban development and the monitoring geomorphological process - systems response during and after the urban development, the aim being to establish a theoretical framework and values used in management strategies and the involvement in making some projections that may occur in connection with urban expansion [2] "Urban geomorphology examines the geomorphic constraints on urban development and the suitability of different landforms for specific urban uses; the impact of urban activities on earth surface process, especially during construction; the landforms created by urbanization, including land reclamation and waste disposal; and the geomorphic consequences of the extractive industries in and around urban areas" [3, 4]. "Local landforms have played a central role throughout history in the choice of sites for settlements and their further development has often been influenced by regional geomorphology [5].

\section{THE STUDY AREA}

Situated in the south of Romania (Fig.1), in the centralsouth area of South West Oltenia Development Region, the City of Craiova is bordered by the folowing geographical coordinates: $44^{\circ} 16^{\prime} 05^{\prime \prime}$ and $44^{\circ} 22^{\prime} 43^{\prime \prime}$, north latitude and meridians $23^{\circ} 42^{\prime} 28^{\prime \prime}$ and $23^{\circ} 54^{\prime} 20^{\prime \prime}$ east longitude. The intersection of the European roads E70 (Spain - Georgia), E79 (Hungary - Greece) and E574 (Craiova - Bacău) mark the center of the city.

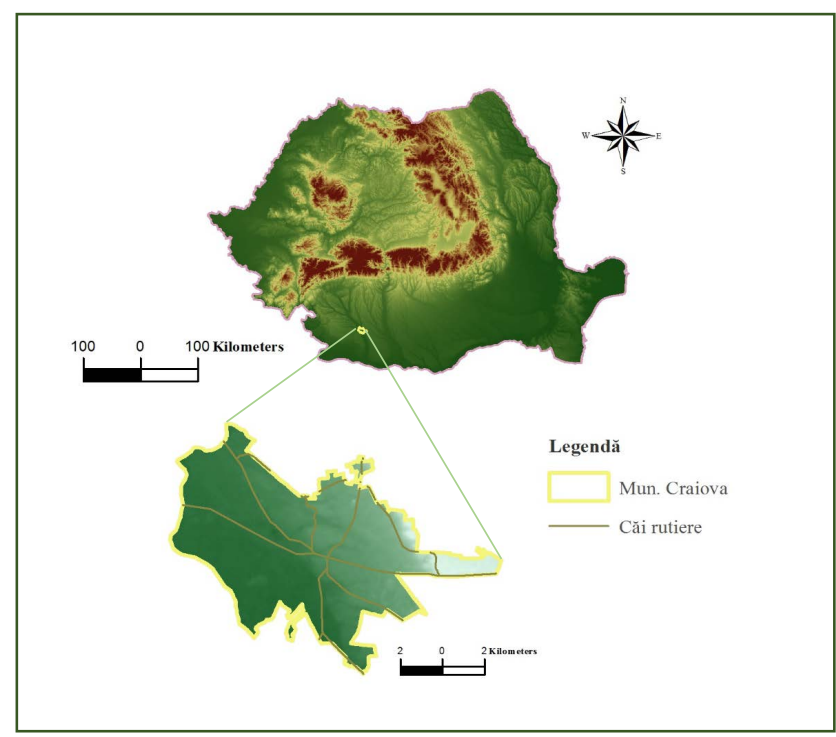

Fig. 1. The localization of the study area on Romania map

The administrative territory has a maximum extension on the west - east direction of $15.7 \mathrm{~km}$, the most part of it on the Jiu terraces and a minimum extension on the northsouth direction, of $5.2 \mathrm{~km}$, covering a surface of $81.96 \mathrm{~km}^{2}$.

Within the borders of the city are included natural limits such as the Jiu river (western border) and its tributary Amaradia, which forms the northern border. The settlement was developed at the contact between Getic Piedmont and Romania Plain, benefitting from the fertility of the Jiu valley and protected by the hills from the west 
(Bucovăt hill) and a swampy area in southern-east side. The landscape resulted behind the movement of the Jiu river towards west (five steps of terraces) influenced both the location and the further extension of the settlement.

The first human communities in the area of the current city are associated with the Neolithic Age (6000-2500 B.C.), then there is evidence of permanence of the settlement like village, then regional fair that included in its perimeter the villages from surroundings, too and since 1582 Craiova has been called a city [6].

\section{THE MORPHOMETRY AND GEOMORPHOGRAPHY OF THE STUDY AREA}

In addition to the analysis of the territory, the study of topographic maps (topographic military map 1: 25.000, published in 1975; topographic military map 1: 100.000, published in 1996) and the written materials about the natural aspects of the area, we used for this study the ArcGIS 10.5 software, for the interpretation of data provided by the COPERNICUS programme, which is managed by the European Commission. The Digital Elevation Model over Europe (EU-DEM) represents a hybrid product based on SRTM and ASTER GDEM data. The dataset which covers Europe was published on 20 April 2016, offering 1992 tiles at 4000 x 4000 pixel realized at a $25 \mathrm{~m}$ resolution.

Regarding altitude, the city of Craiova appears like an amphitheater that starts at $70 \mathrm{~m}$ altitude, on the west side and extends gradually until $199 \mathrm{~m}$ in east side. The minimum elevation, $69 \mathrm{~m}$ is recorded in the south-west extremity, in the flood-plain terrace of Jiu, at the contact with the village Balta Verde. Between these extremities (east north-eastern side and west south-west side) there results a difference of $129 \mathrm{~m}$. Approximately $40 \%$ of the city surface is underneath $85 \mathrm{~m}$ contour, beyond the hypsometric step of $180 \mathrm{~m}$ being only a very small area the airport area (the east extremity).

The lower terraces are covered with surfaces with a very low declivity (under $3^{\circ}$ ), the only exception being the Tineretului Park, located in the flood-plain terrace, where there are registered slopes between $3^{\circ}-5^{\circ}$. At the linkage with the medium terraces, the slope increases to $8^{\circ}$, and the superior terrace presents predominant surfaces with a $10^{\circ}-$ $11^{\circ}$ slope.

In contrast with the left bank, with terraces on which the city extended, the right bank of Jiu, without terraces, includes areas with $10^{\circ}-33^{\circ}$ slope, presenting a low pretability for urban expansion.

In the northern half of the medium terraces there can be distinguished a succession in the slopes' aspect: southsouth-west, then north-northeast-east, the southern side of medium terraces being characterized by the homogeneity in the exhibition of slopes. In the upper terrace the most slopes have a pitch towards north (shadowed slopes), north-west (semidarkness) and south-west.

The five terraces formed by Jiu in its movements towards west are covered by sand dunes which give it a slightly wavy aspect. The lithological substrate is differentiated according to the level of the terraces: the flood plain terrace and the lower terrace - clays, silts, sandy silts, gravels, in medium terraces predominant sands with gravel, partially covered with loess powder [7]. The western slope of the Jiu, with a more pronounced slope, is composed of the loess-like deposits, sands, gravels and reddish clays, favoring linear erosion and mass movement [7].

\section{THE URBAN EXPANSION OF CRAIOVA}

The visual perspective of the expansion dynamic for urban constructions was realized using ArcGIS 10.5, by the interpolation of multitemporal satellite images. To compare expansion of the built areas in different moments there were used the data mentioned in Table 1, but the graphical representation of results (Fig. 2) was simplified for an easy view.

TABLE I. DATA USED FOR THE VISUAL PERSPECTIVE OF THE EXPANSION DYNAMIC

\begin{tabular}{|l|l|l|}
\hline \multicolumn{1}{|c|}{ SATELLITE IMAGES } & \multicolumn{1}{c|}{$\begin{array}{c}\text { Date of } \\
\text { acquisition }\end{array}$} & \multicolumn{1}{|c|}{ Source } \\
\hline Landsat 2, MSS1-5 (100 m) & 09. sep.1977 & USGS \\
\hline Landsat / Copernicus & $31 . d e c .1984$ & Google Earth \\
\hline Landsat / Copernicus & 31. dec.1987 & Google Earth \\
\hline Landsat 5, TM (50 m) & 01. aug.1992 & USGS \\
\hline Landsat / Copernicus & 31.dec.2001 & Google Earth \\
\hline CLC2006 (100m) & Version 13 & EEA \\
\hline Landsat / Copernicus & 31.dec.2009 & Google Earth \\
\hline Digital Globe / CNES / Astrium & 01.feb.2017 & Google Earth \\
\hline
\end{tabular}

Since the establishment of the hearth settlement, the place geomorphology was an important factor, the settlement being established on the left bank of the Jiu, characterized by terraces, in total opposition to the right bank, which is steep and with frequently occurring processes of undermining and collapse [7].

Before the period to which this study is focused on (1977 - 2017), the expansion of the settlement was an asymmetric one, as shown in Map of Specht (1791) with an tentacular extension only on the east side (on medium terraces of Jiu), the western side of the main road along which it was formed, leaving only with a linear expansion. Lack of the corresponding extension on the west side was determined by the swamp flood plain, a remnant of the former meanders and abandoned courses of the Jiu, results of its movement westward. The swamp areas from the western and southern part of the city (lower terraces) represented not only a restriction in urban development, but also an unhealthy environment and a source of and epidemics, which determined the drainage and sewerage slough and marshes in the late nineteenth century and early twentieth century. But even after the draining slough and sewage water, in the period considered particularly since 1977, the expansion of urban construction is significant on upper terraces, in the detriment of the flood plain terrace.

From the constructed surface point of view, the dynamic in the mentioned period had a permanent expansion, from $27.16 \mathrm{~km}^{2}$ in $1977,42.45 \mathrm{~km}^{2}$ in 1987 , $61.31 \mathrm{~km}^{2}$ in 2009 , currently the constructed surface being of $73.02 \mathrm{~km}^{2}$. Compared with 1977, when the built area covered mainly terraces II and III, and was situated between altitudes of 75 and $120 \mathrm{~m}$, currently expanding urban housing has extended between altitudes 70 and 195 $\mathrm{m}$. In the floodplain terrace the expansion of construction 
is straighter along the road, but on the terraces IV and V the expansion of buildings is uniformous and pronounced.

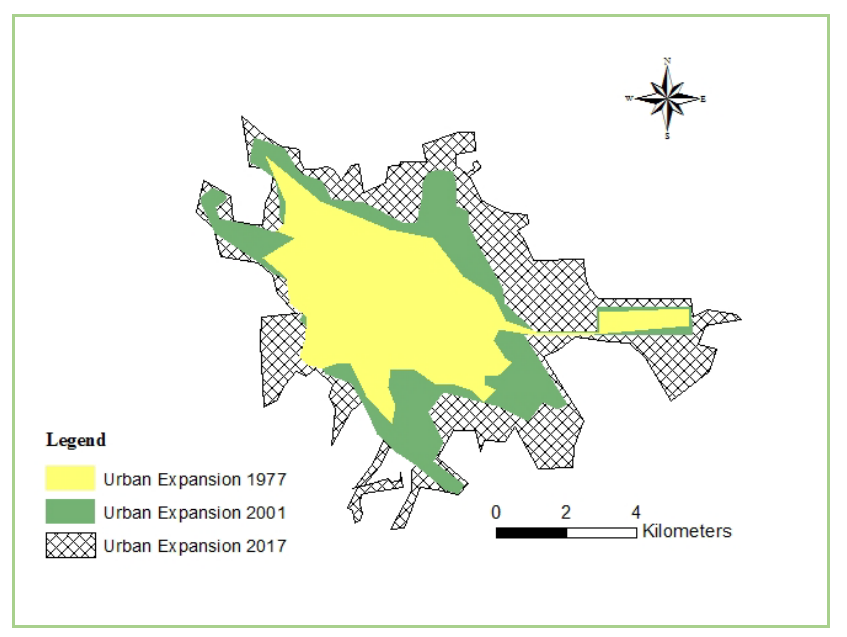

Fig. 2. The expansion of the built environment

\section{CONCLUSIONS}

The area situated on the left bank of the Jiu, between the Getic Piedmont and Romanian Plain, defined by an altitudinal gradually progress from 70 to $190 \mathrm{~m}$, on W-E direction, with a very low slope, has facilitated the extension of the settlement. The right Jiu bank, with a slope between $10^{\circ}-33^{\circ}$, and with a potential risk of land slide was not an attractive factor in the urban expansion. The development on the west - east direction was also conditioned by the potential hydrological risk from the south.

The areas that have extensive urban construction during 1977 - 2017 consist predominantly of the upper terraces of the Jiu with a reduced average slope, under $5^{\circ}$, and less on the flood-plain terrace, which presents an unfavorable lithological composition.
The result of this study shows a predominantly expansion on the eastern direction, the largest expansion was recorded in the last period (2009 - 2017), with a trend of expansion of the area to the east in the future, too.

The disproportionate urban sprawl, predominantly on one side of the city, required the focus of administrative efforts, too, in achieving the general infrastructure and public utilities in the area of where constructions have been developed.

The correlation of a geomorphic study with a historical perspective on the expansion, is an important tool in the anticipation of future needs, having the aim to increase the quality of living and life in general, but also directing the urban expansion towards the balanced used of the land.

\section{REFERENCES}

[1] I. Douglas, and P. James, Urban Ecology: An Introduction. Taylor \& Francis, 2014

[2] R.U. Cooke, “Urban Geomorphology”, The Geographical Journal, 142(1), pp. 59-65, 1976.

[3] I. Douglas, Cities: An Environmental History. I.B. Tauris, 2013.

[4] I. Douglas, D. Goode, M. Houck, and R. Wang (Eds.), The Routledge Handbook of Urban Ecology. Routledge, 688 p., 2010.

[5] G.D. Bathrellos, "An overview in urban geology and urban geomorphology”, Bulletin of the Geological Society of Greece, vol. 40, pp. 1354 -1364, 2007.

[6] T. Georgescu, C. Barbacioru, and F. Florea, Istoria Craiovei. Craiova: Editura Scrisul Românesc, 289 p., 1977. (in Romanian)

[7] I. Irimus, and S. Boengiu, "Substratul morfo-litologic" în "Strategi de dezvoltare urbană. Municipul Craiova”, P. Cocean, Ed. 2011. Presa Universitară Clujeană: Cluj Napoca, 2011, pp. 9-13. (in Romanian) 


\title{
Identifying ground displacement trends in Bucharest using InSAR
}

\author{
(summarizing of research findings at CRMD)
}

\author{
Iuliana Armaş \\ Department of Geomorphology-Pedology-Geomatics \\ University of Bucharest, Faculty of Geography \\ Bucharest, Romania \\ iulia_armas@geo.unibuc.ro
}

Diana A. Mendes

Department of Quantitative Methods for Management and Economics

ISCTE-IUL and BRU-IUL

Lisbon, Portugal

diana.mendes@iscte.pt

\author{
Răzvan-Gabriel Popa \\ Institute of Geochemistry and Petrology \\ ETH Zürich \\ Zürich, Switzerland \\ razvan.popa@erdw.ethz.ch
}

\author{
Mihaela Gheorghe \\ Faculty of Geodesy \\ Technical University of Civil Engineering of Bucharest \\ Bucharest, Romania \\ mihaela.gheorghe@utcb.ro
}

\author{
Diana Popovici \\ Department of Geomorphology-Pedology-Geomatics \\ University of Bucharest, Faculty of Geography \\ Bucharest, Romania \\ diana_popovici@geo.unibuc.ro
}

\begin{abstract}
Some of the most popular multi-temporal interferometric techniques used in monitoring surface movements have been applied for capturing the spatial evolution patterns of Bucharest. Three sets of $C$ and $X$-band single polarized SAR images (Envisat, ERS and TSX) were processed using the PS (Persistent Scatterers) and SBAS (Small BAseline Subset) techniques. The processing results consisted of deformation maps offering an image of the line of sight displacement rates in the past. In both PS and SBAS cases, displacement rates values are of the orders of millimetres. The analysis of possible trends is focused on relevant areas with a potentially interesting historical evolution, such as former clay pits, landfill excavation sites and industrial platforms. The InSAR techniques made it possible for the first time to investigate movements over large urban areas in combination with results derived from classical methodologies (diachronic cartography, geology, geomorphology) and thorough statistical analysis. The analyses lead to a new hypothesis regarding the geological processes that affect the surface evolution patterns in Bucharest.
\end{abstract}

Keywords- Bucharest; PS InSAR; SBAS InSAR; deformation maps; ground displacement trends; transpressional system

\section{INTRODUCTION}

Captured the space-time evolution of Bucharest, was a constant research goal at the CRMD center of the University of Bucharest, Faculty of Geography (www.geodinamic.ro). Early research focused mainly on different vulnerabilities of the urban environment, and more recent issues addressed explicitly instabilities occurred from ground behavior and displacement trends based on multi-temporal InSAR methodologies (applied to ERS, ENVISAT and TerraSAR-X satellite data). The radar displacement products were validated using Global Navigation Satellite Systems (GNSS), leveling geodetic measurements, and by conventional geological and geomorphological methods. The present paper summarizes the main outcomes of our research effort, aiming to draw a more concise image of ground evolution patterns in Bucharest.

\section{MethodOLOGY}

For analyzing ground deformation in Bucharest, we processed 79 SAR images acquired by the European Space Agency (ESA) ERS -1/-2 and ENVISAT satellites and by the German Aerospace Centre (DLR) TerraSAR-X (TSX) satellite. The images covered a time span of almost 20 years, with the historical satellite data consisting of 28 ERS-1/-2 images, acquired between 1992 and 1999, 24 
ENVISAT images, acquired between 2003 and 2010 and 27 high resolution images acquired by the TSX satellite between 2011 and 2014. Because the interferometric phase is influenced by a series of factors like the signal strength, the satellite-target relative position or temporal changes in the scene or atmospheric fluctuations, these images were selected from a larger pool of SAR data by eliminating those acquired under poor weather conditions or datasets with large perpendicular.

Two of the most known InSAR techniques were used to process the data stacks: The Persistent Scatterer technique and the Small Baseline Subset technique.

The Persistent Scatterer technique was introduced by [1] to overcome some limitations of the SAR interferometry, often affected by temporal, atmospheric or geometrical decorrelation. The method is applied for ground monitoring and it is based on identifying stable reflectors in the SAR scenes of the same area. The stable reflectors are known as persistent scatterers and are represented by natural and mostly man-made objects that are usually coherent to the radar signal (buildings, infrastructure, light poles, rocks, etc). The scatterers are useful in identifying crust deformations with millimeter accuracy and to improve DEM accuracies (submeter level) over large areas. In the PS interferometric process, one master file is defined for each data stack (i.e., ERS, ENVISAT and TSX), and the interferograms are formed relative to the defined master image.

The basic principle of the SBAS technique consists in a suitable combination of multiple interferograms with corresponding small baselines [2]. Instead of a single master file, this technique generated small baseline interferograms that result from coupling SAR images with suitable temporal and spatial baseline. The resulted small baseline interferograms are implemented in a linear model where the combination of small baseline depends on the vector containing values of the unwrapped differential interferometric phase. By solving the linear model, the sampling rate of the method is increased, while phase noise is reduced and backscatter preserved by choosing a coherence threshold. Like in the case of the PS method, only coherent pixels are exploited, but in this case, the values of the coherent pixels are interpolated over larger areas using Delaunay triangulation as described by [3].

The PS processing chain has been applied to all 3 stacks of SAR images, while the SBAS was only used to process the TSX database. SARMAP's SARscape software was employed for carrying out the processing. The InSAR pairs selected for the PS algorithm were referenced to a master acquisition from 26th of June, 2012. For the SBAS algorithm, a perpendicular base of less than $500 \mathrm{~m}$ and a temporal baseline of less than 2 years were set as parameters. With these considerations we obtained a number of 26 interferograms for the PS algorithm and 178 for the SBAS algorithm. The influence of topography was removed by using an external Digital Elevation Model (DEM), a level 4 SRTM-X, available from DLR.

\section{Results AND Discussions}

\section{A. InSAR}

The results of the processing techniques consisted of deformation maps over Bucharest (Fig. 1). The techniques applied can measure very small deformations (e.g., 1 $\mathrm{mm} /$ year) allowing a synoptic view of Bucharest ground deformations. Over the urban and peri-urban areas, PS InSAR analysis resulted in approximately 30,000 PS points from ERS data, more than 60,000 for ENVISAT and almost 600,000 points for TSX. The SBAS analysis on TSX data returned over $1,000,000$ points. In each of the represented point, the algorithms determined yearly displacement rates ranging between -8 to $2 \mathrm{~mm} / \mathrm{yr}$ and displacement values from an acquisition date to another. The estimated velocity precisions were $\sim 0.3 \mathrm{~mm} / \mathrm{yr}$ for ERS and ENVISAT and $\sim 0.2 \mathrm{~mm} / \mathrm{yr}$ for TSX.

The resulted velocity values were validated by means of GNSS technology. We found a good agreement between displacement rates resulted from InSAR data and terrestrial measurements [4].

\section{B. Tested areas: Historical Clay Pits and Excavation Sites}

During an urban area's development, there is a rising demand for construction materials. The main local construction material in Bucharest was clay for bricks. Diachronic analysis of historical clay pits and excavation sites in Bucharest was based on archived cartographic materials (Table 1). In total, 67 historical pits were identified. The clay pits were located at the periphery of the city, and their surfaces would vary up to almost 20 square meters. The pits with the largest surface were: Cerchez and Tonola in the North, Vergului in the East, and Cuţarida and Ouatu in North-West. From a geomorphological point of view, most of the pits are found on the interfluve between the Dâmboviţa and Colentina Rivers; only a few of them are found in the Dâmboviţa River's corridor (Fig. 2).

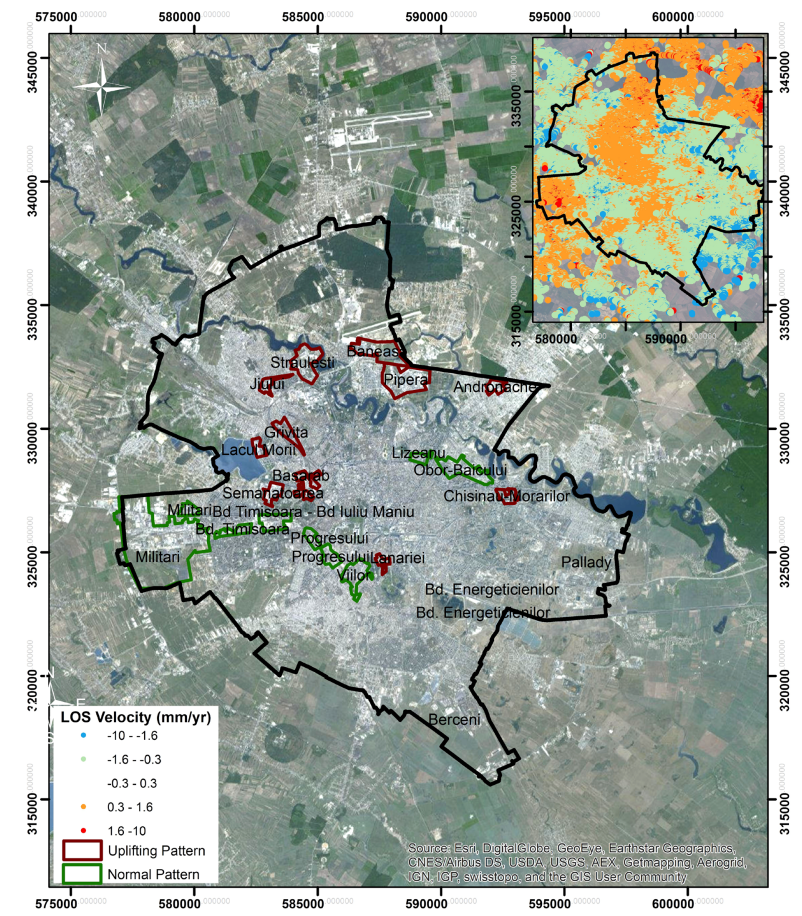

Fig. 1. Ground deformations over industrial parks. Right corner: SBAS deformation map 
TABLE 1. AREA OF EXCAVATION SITES

\begin{tabular}{|c|c|c|c|}
\hline \multirow{2}{*}{$\begin{array}{c}\text { Maps and } \\
\text { cartographic planes } \\
\text { (Year) }\end{array}$} & $\begin{array}{c}\text { Number } \\
\text { of } \\
\text { excavations }\end{array}$ & \multicolumn{2}{|c|}{ Area (ha) } \\
\cline { 3 - 4 } & 17 & 19.3 & $\begin{array}{c}\text { Maximum } \\
\text { area of an } \\
\text { excavation }\end{array}$ \\
\hline $\begin{array}{c}1854 \\
\text { (Borroczyn Plane) }\end{array}$ & 19 & 15.3 & 12.4 \\
\hline $\begin{array}{c}1871 \\
\text { (Pappasoglu Plane) }\end{array}$ & 39 & 91.2 & 2.8 \\
\hline 1914 & 3 & 5.6 & 16.8 \\
\hline 1940 & & & 3.1 \\
\hline
\end{tabular}

Between 1854 and 1871, the number of excavations increased, while their areal extent decreased. This is mainly because the number of large excavations was reduced in favour of constructing new buildings. During this period, many brick factories (e.g. Tonola, Cerchez) were established, together with small outdoor workshops; the periphery of the city contained many pits. Between 1917 and 1940, a significant decrease in this type of activity could be observed, most of the former clay pits and excavation sites being upgraded to different land use categories, and integrated into the urban landscape. After 1940, excavation sites from outside the city ceased to be marked on maps.

An uplift trend can be identified for the former excavation areas that are on the interfluves between Dâmboviţa and Colentina (Witing Street, the Ştefan Cel Mare-Dinu Vintilă Boulevards in Fig. 2).

The general uplifting trend of excavations found on interfluves aligns with the regional uplift movement (although 10 of the excavations show subsidence in the period 1992-2000, which we link to the fluctuations of the groundwater table, as explained later).

The subsidence trend was detected at a historical excavation site located around the current Bucharest Autonomous Transport Company (RATB) car shed Dudeşti, found on the Dâmboviţa terrace, as a consequence of tectonic conditions, discussed later in the paper.

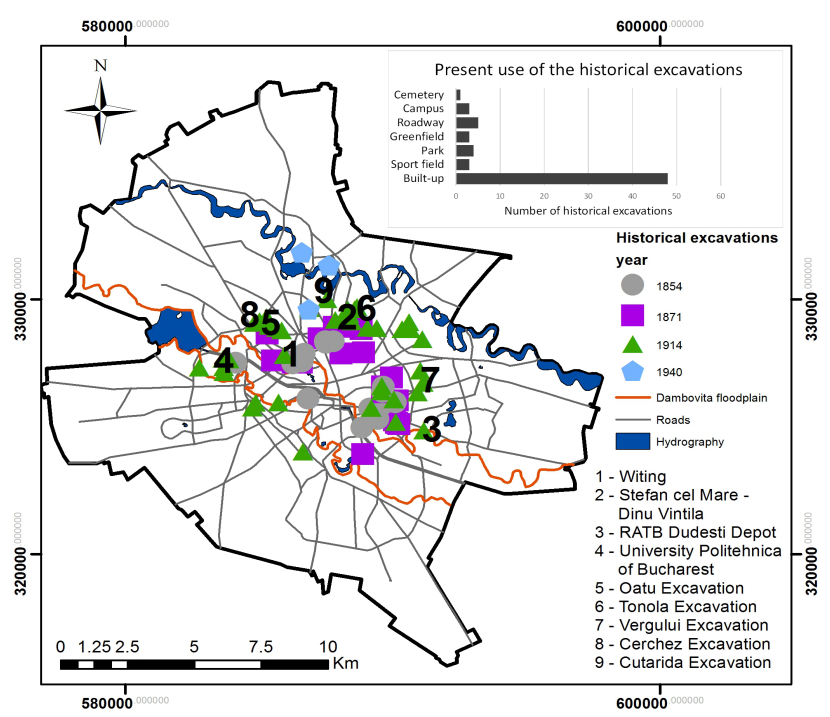

Figure 2. Historical clay pit excavations

\section{Tested areas: Industrial parks}

We concentrated our analysis on large areas that were most affected by human influence. We calculated the mean deformation rates in each period for 20 important industrial parks.

Movement trends over each of the study areas were analyzed through manual recognition and classification. The behavior of the areas, translated in movement trends, were interpreted considering geomorphologic characteristics, groundwater level changes over time, and historical evolution of the area [5]. We have discovered three main dynamic trends of the industrial areas. In this paper we will focus only on the expected (or normal) pattern with subsidence until 1999 followed by uplift after 2003, and the pattern characterized by continuous uplift. The third pattern, a subsident one, was detailed in previous research and will not be developed in this paper [5] [6]

The selection of the study areas was made especially considering criteria of human impact, in order to identify the long-term dynamic pattern, with natural causes, disturbed by medium-term human impact. The analysis of the industrial areas described in a former study [5] represented a basis for a more detailed investigation in a paper published in Scientific Reports [6]. Different industrial parks in Bucharest represent suitable test sites for identifying long-term dynamic patterns through comparative analysis with their neighboring areas. The main hypothesis of our research was that areas affected by human impact are recovering after shutting down most of the industry in Bucharest and are tending towards the normal long-term trend of ground evolution. The long-term trends are emphasized by contrast with the short- or medium-term trends of the human impacted areas within the city. Complex statistical analyses were carried out and the results were presented on different occasions [4] [5] [6].

\section{Ground displacement patterns}

After applying statistical and numerical tests, we have identified a persistent long memory behavior in each of the analyzed displacement time series.

The long-term behavior describes three quasi-parallel NW-SE uplift domains separated by 2 subsidence corridors. The main uplift area corresponds to the interfluve between Dâmbovița and Colentina rivers. Interestingly, this area hosts most of the buildings that are catalogued as class I, II and III of seismic risk, and most of the buildings that have collapsed during the 1977 earthquake.

Investigating the ground deformations caused by the identified uplift is hindered by the geological substrate of Bucharest, made of unconsolidated or plastic rocks that do not easily retain visible deformation or movement markers. To overcome this issue, our working hypothesis considered that taller buildings with deep foundation are better coupled with the geological substrate and might react similarly. The buildings however, have the ability to record movement or deformation markers via fractures or fissures in their structures.

A classical geological methodology has been applied in an unconventional way: the azimuth of the discontinuities that could be traced in more than 1 structural plane of the 
investigated buildings has been measured with the geological compass. The distribution of fissures in the man-made structures are indicated of dissociated stresses induced by a NW-SE strain field. Thus, the connection between the NW-SE uplift domain and the compromising of the buildings structures is a potential conclusion. Bucharest is located just $40 \mathrm{~km}$ west of the Intra-Moesian Fault Line, and it seems likely that the city was built on a peripheral section of this fault system. Differentiated movement (different velocities) on the main faults or on the secondary adjustment faults can create transpressional fields that result in shortening and uplift.

\section{CONCLUSIONS}

The main challenges we had to face in our attempt to identify ground displacement trends in Bucharest were a low backscattered radar signal in the absence of a validated neotectonic model, and the lack of permanent GNSS stations within the city to test our InSAR results. We overcome these aspects by selecting only highly reliable imagery from a larger pool of data, and installing throughout the city centering systems at ground level for GNSS receivers. Therefore, we were able to obtain and validate deformation maps that describe Bucharest's ground surface movement patterns. We then carried out complex statistical analysis on the resulted data that pointed out to a nonlinear periodic process caused by possible attractors, possible explained by an active transpressional system that Bucharest is built on.

\section{ACKNOWLEDGMENT}

This research was financed by grant 78/29.11.2013 of the Romanian Space Agency. ERS-1/-2 and ENVISAT data were provided by ESA under the ESA AO CAT-1 proposal (i.e., Project 12793), PI's M. Necșoiu and I. Armaș. TSX data were provided via DLR Proposal LAN 1444, PI's I. Armaş and M. Necşoiu. We would like to thank Dr. Eng. Marius Necșoiu for support in processing InSAR data.

\section{REFERENCES}

[1] A. Ferretti, C. Prati, and F. Rocca, "Permanent scatterers in SAR interferometry," IEEE Transactions on geoscience and remote sensing, vol. 39, no. 1, pp. 8-20, 2001.

[2] P. Berardino, G. Fornaro, R. Lanari, and E. Sansosti, "A new algorithm for surface deformation monitoring based on small baseline differential SAR interferograms”, IEEE Transactions on Geoscience and Remote Sensing, vol. 40, no. 11, pp. 2375-2383, 2002.

[3] M. Costantini, and P.A. Rosen, “A generalized phase unwrapping approach for sparse data”, Geoscience and Remote Sensing Symposium. IGARSS'99 Proceedings. IEEE 1999 International, vol. 1, pp. 267-269, 1999.

[4] I. Armaș, M. Gheorghe, A.M. Lendvai, P.D. Dumitru, O. Bădescu, and A. Călin, "InSAR validation based on GNSS measurements in Bucharest,” International Journal of Remote Sensing, vol. 37, no. 23, pp. 5565-5580, 2016.

[5] I. Armaș, M. Necsoiu, D.A. Mendes, M. Gheorghe, D. Gheorghe, "Ground Displacement Trends in an Urban Environment Using Multi-Temporal InSAR Analysis and Two Decades of MultiSensor Satellite-Based SAR Imagery,” In Proceedings of ESA 9th International Workshop Fringe 2015 Advances in the Science and Applications of SAR Interferometry and Sentinel-1 InSAR Workshop, ESA SP, Vol. 731, May 2015.

[6] I. Armaş, D. Mendes, R.-G. Popa, M. Gheorghe, D. Popovici, "Long-term ground deformation patterns of Bucharest using multitemporal InSAR and multivariate dynamic analyses: a possible transpressional system?”, Sci. Rep. 7, 43762, 2017. doi: 10.1038/srep43762 


\title{
Geomorphic services for landslide risk evaluation in the RO-RISK Project
}

\author{
Dan Bălteanu, Marta Jurchescu, Mihaela Sima, Mihai Micu, Gheorghe Kucsicsa \\ Institute of Geography \\ Romanian Academy \\ Bucharest, Romania \\ igar@geoinst.ro,marta_jurchescu@yahoo.com
}

\begin{abstract}
The paper presents the steps undertaken within the RO-RISK (Disaster Risk Evaluation at National Level) project with the aim of achieving landslide hazard and risk evaluation at the national level, as well as the close interand transdisciplinary collaboration through the involvement of specialists and stakeholders during the whole research process, the results of which can be assigned to geomorphic services. A common methodology to analyze all the selected risks has been followed within the project, mainly focusing on hazard and impact analyses. At the end, three national and two local scale landslide scenarios have been analyzed into detail in order to provide risk figures as estimations on the location and magnitude of possible physical impacts on the population, the built-up environment and the transportation network, as well as economic and sociopsychological impacts, all of which were needed to finally estimate risk acceptability.
\end{abstract}

Keywords - landslides; risk assessment; geomorphic services; environmental changes; RO-RISK; Romania

\section{INTRODUCTION}

By engaging more and more in different projects, Geomorphology provides scientific services to decision makers and other relevant institutions in diverse fields such us civil protection, territorial planning and land management etc. These services are differentiated considering the spatial scale as well as the quality of the data and include geomorphological mapping and zoning, laboratory and field experiments, geomorphologic assessment using qualitative and quantitative methods and modeling.

The geomorphic services, together with climatic and ecosystem services, may provide support to increasing the resilience of society to extreme events, being suitable for economic assessment and for undertaking disaster management measures. The scientific services are based on a close inter- and transdisciplinary collaboration along with the involvement of specialists and stakeholders during the whole research process and include several steps: co-design (project structure, identification of the main issues), co-production (research stages followed by common analysis of the results and uncertainties) and results dissemination [1].

This study was developed in the framework of the RO-RISK project (2016) coordinated by the Romanian General Inspectorate for

Emergency Situations (GIES) and co-financed by the European Social Fund through the Operational Programme for Administrative Capacity (POCA).
In this context, through the geomorphological research on landslides undertaken within the RO-RISK project, synthesis data on landslide hazard and risk at national level have been produced as a support for the decisions undertaken by civil protection in managing this risk.

\section{THE RO-RISK PROJECT}

National risk assessment is considered by the European Commission a topic of highly importance and therefore became a conditionality for accessing European Funds in the 2014-2020 time period. In order to comply with this conditionality, the RO-RISK (Disaster Risk Evaluation at National Level) project was undertaken in 2016, being coordinated by the General Inspectorate for Emergency Situations (GIES, at the same time the main stakeholder) and co-financed by the UE through the European Social Fund in the frame of the Operational Program Administrative Capacity 2014 - 2020.

Developed as such, the project aimed to provide a framework for the risk assessment process in Romania, thus contributing to strengthening risk prevention and management in the country. It focused on assessing the specific hazards and risks occurring on the Romanian territory. In order to ensure a proper identification of risks having major impact at national level and their integrated management, research and consultation activities have been undertaken, before the start of the actual assessments, to set out a common language base and a coherent and unitary frame for the analyses. The resulting methodology for risk evaluations and integration of individual risk assessments [2] was constantly subject to improvements during the projects' implementation as risk assessment activities were advancing.

The project identified 10 types of hazards and risks significant for the national security. Therefore, scientific evaluations performed in the frame of the project, by research institutes as well as central administration institutions, have been concentrated on: floods, drought, forest fires, landslides (slides), earthquakes, nuclear and radiological accidents, Seveso accidents, major accidents involving dangerous substances, epidemics, animal epidemics and zoonosis. Besides research, the project also 
included consultation activities with various stakeholders involved in risk management and assessment [3].

\section{THE PROCESS OF LANDSLIDE RISK ASSESSMENT AND MANAGEMENT}

The majority of landslide studies are conducted with the final goal of providing risk estimation, i.e. a measure of the expected losses due to landslide hazard. Estimated levels of risk can subsequently be subjected to evaluation through a cost-benefit analysis which would differentiate among intolerable, tolerable and acceptable risks. The risk treatment phase requires comparisons with other risks, discussions and evaluation of treatment options, also including cost-benefit analyses of proposed risk treatment measures. This entire process, comprising the abovementioned successive phases and concluding with the implementation of policies and measures for risk reduction, is known as risk management.

The landslide risk component of the RO-RISK project, as was the case for every project component dedicated to the evaluation of one individual risk, was overall structured according to the main stages making up the risk management process. The landslide (slide) risk estimation is based on integrating two major factors referring to the probability patterns (hazard analysis), the identification of the elements at risk and their vulnerability (impact analysis), according to the well-known formula [4]:

\section{Risk $=$ hazard $\times$ vulnerability $\times$ elements at risk}

In the initial, scoping phase of the co-design process, numerous discussions among experts and the main stakeholder took place, concerning the selection of the optimal methodology to be employed throughout the project, the resources needed as well as the level of detail for the analysis. Following these and aiming to provide scientific assessments for the main components of the landslide risk management process, framing methodologies were adopted, respecting international recommendations in the field, and adapted, on the one hand, to the specific morpho-structural, climatic and socio-economic environment and, on the other hand, to the available resources. This was the first complete approach of this kind to be undertaken at a national scale in Romania, after the elaboration of the country's landslide susceptibility map [5].

As required, an important stage was dedicated to analyzing the hazard, i.e. the probability of occurrence of a damaging landslide of a given magnitude. Research focused on separately assessing the spatial probability, given by the terrain predisposing conditions, the temporal frequency and the magnitude of such processes.

Landslides respond either fast or delayed to triggers like precipitation, earthquakes, fluvial erosion or human interventions in the environment. During the last two centuries, several events were responsible for initiating a large numbers of landslide processes, e.g. the large earthquakes of 1809 and $1838(\mathrm{M}=7.5-7.9)$, the moderntime earthquakes of 1940 (M 7.7) and 1977 (M 7.4), the rainy period of 1968-1974, the wet seasons of 2004, 2005, 2006 and 2010 [3, 6, 7]. As for the relationship between landslide typology and major triggers (precipitation, earthquakes), there's a rather incomplete correlation of parallel inventories, which cannot support, for the moment, typological specifically-addressed susceptibility/hazard maps. However, the available information allows some empiric correlations: low magnitude earthquakes $\left(M_{w} 4-5\right)$ are likely to trigger rock falls, disrupted debris and earth slides, while an increase of magnitude (above $\mathrm{M}_{\mathrm{w}}$ 6-7) can lead to a shift towards rock slumps, rock block slides and earth flows [8,9]. The spring showers are triggering both shallow earth slides and medium-to-deep seated (when overlapping snowmelt) complex/compound landslides, while torrential summer precipitation are responsible for earth/debris flow pulsations.

A large number of landslide hazards scenarios (40) were constructed based on the previous analysis of spatiotemporal relationships among the most relevant predisposing, preparatory and triggering factors. As part of the climatic factors, precipitation was selected as having the most important landslide triggering role, which lead to elaborating 34 rainfall-induced scenarios. Relevant climatic parameters were considered and statistically computed: maximum seasonal rainfall, maximum $72 \mathrm{~h}-$ rainfall and extreme length of wet intervals with different return periods [10]. Earthquakes are widely considered another important landslide triggering factors. Among the numerous seismic regions of Romania, Vrancea intermediate acts as the most active one, with documented effects for several earthquakes. Based on these considerations, 4 earthquake-induced landslides hazards were also evaluated through deterministic (reproducing the Vrancea intermediate recent major earthquakes of 1940 and 1977) and probabilistic approaches. The trigger indicators' maps, displaying the distribution of either extreme precipitation amounts or peak ground acceleration (PGA) values, were overlaid with the susceptibility map following an expert-judgment approach, producing hazard classifications.

Not only current conditions but also possible future environmental changes were considered in obtaining the various hazard scenarios. In case of the climatic factors, possible future evolutions were accounted for on the basis of climatic projections for the periods 2021-2050 according to IPCC climate change scenarios (RCPs 4.5 and 8.5) and selected EURO-CORDEX regional climate models [10]. In the construction of landslide hazard scenarios, spatial data on future dynamics of land use/land cover (year 2050) were also considered, being modeled by CLUE-S (the Conversion of Land Use and its Effects at Small regional extent), a model that allows to simulate land use/land cover changes using diverse development scenarios [11]. In the RO-RISK project, the Corine Land Cover database together with physiographic and socioeconomic data have been used to generate 31 causal factors for change, grouped within the main land use/land cover simulation categories.

The further in-depth analysis required a selection of three national-coverage scenarios based on pre-imposed prioritization criteria of likelihood and severe potential impacts. These were described into more detail with the purpose of identifying information on the environment, the population and the human and economic assets existing in the hazard-threatened areas. Additionally, two local-scale scenarios basing on different methodologies 
have been designed and subsequently analyzed into detail, following the project's methodological flow.

The analysis of elements at risk was undertaken at the level of LAU2 units for several indicators as: demography (total population and population density); number of residential buildings; main land use/land cover categories; protected areas; transport infrastructure (lengths of roads and railways); public utility network (water and heating supplies). Hazard exposure has been assessed by quantifying the elements at risk for the high and very high hazard classes in case of the selected 10-year and 100-year national scenarios.

Three impact types and 17 impact criteria were investigated within the project for each individual risk, in order to allow for subsequent comparisons among risks: physical (loss of life, persons injured, evacuated and without access to essential services, affected buildings, transportation networks, lifelines, response means, protected areas and other affected areas), economical (costs associated to human losses, material and environmental damages, emergency response forces, indirect costs), social and psychological impacts (interruption of daily life, societal psychological impact). The same descriptors were used to express these impacts for the various risks, being preimposed through the established methodology [2]. Estimation of vulnerability was therefore subordinated to the requested impact assessments. Landslide vulnerability was addressed through integrating the approaches used in social and climate-change related sciences as well as in natural sciences. This allowed to develop several assessment steps: i) estimation of an intrinsic vulnerability; ii) identification of a hazard-specific vulnerability and, finally, iii) quantification of the expected degree of loss using recent historical information on landslides-induced damages [12]. The latter step enabled to compute first estimations on the location and magnitude of possible physical impacts on population, the built-up environment and the transportation network.

Collaborations with other institutions in the field of economics and social sciences permitted data sharing and transfer, the physical impact estimates forming the input to further evaluations regarding the economic and the social and psychological impacts. Finally, all impact criteria were combined in order to derive a global impact for each selected scenario.

\section{GEOMORPHIC SERVICES PROVIDED BY RO-RISK}

Scientific services are increasingly recognized as a way to transfer knowledge to end-users, constituting the necessary link between science and practitioners.

The work, aimed at evaluating the landslide risk in the framework of the RO-RISK project, proposes several scientific services in each stage of the analysis.

Landslide zonation maps were elaborated, allowing the identification, across the national territory, of hotspot areas in terms of terrain susceptibility, hazard, elements at risk, exposure, vulnerability, impact and risk, and being associated to different present-day or future conditions.

As mentioned above, in the course of the assessment process also future environmental evolutions were taken into account. Consequently, trends in the spatial distribution and levels of landslide hazard and risk could be identified for different time horizons (up to 2050) as a response to land-use and climate changes.

Evaluation and calibration/validation of results is considered essential prior to delivering the outcomes in the form of scientific services. In the landslide component of the RO-RISK project, this was achieved by means of expert knowledge. In this sense, a strong collaboration was undertaken with specialists from the Babeş-Bolyai University in Cluj-Napoca and the "Alexandru Ioan Cuza" University of Iaşi, who provided the necessary knowledge on regional aspects.

Computed impacts and likelihoods values associated to the priority landslide scenarios were synthesized and placed on risk matrices designed to allow for comparisons with the other natural and technological risk scenarios.

The shaping of geomorphic services was based on a strong collaboration with the main beneficiary of the project, GIES. In this respect the main results were continuously tailored to its specific needs and requirements. As an example, one requirement for risk evaluation was to identify the degree of risk tolerance based on a standard scale proposed by the beneficiary and based on thresholds for impact and likelihood.

One major outcome of the project, namely the evaluation maps, have been disseminated though a webplatform where all individual risk assessment results were brought together and put into a standard format in order to be comparable.

\section{CONCLUSIONS}

Slope instability in Romania is believed to have increased in the recent period due to a general degradation of management works (after 1990), climate change and human pressure on the environment (e.g. deforestation).

The RO-RISK project provided a first scientific basis for the national level assessment of natural and technological risks including landslides and is intended to be continued and improved. Such an assessment should be meant to function as a support for proposing risk treatment options and plans and providing capacity building for national and local authorities. Results achieved in the field of landslides are expected to serve a national integrated disaster management planning, at the same time indicating where more detailed assessments would be needed. Given the scale at which the evaluations were conceived, attention is drawn to the fact that outcomes are not meant to be used for regional development or local land planning, management of existing or proposed transportation or utility infrastructures, the development of engineering works etc.

In spite of the several calibrations and corrections provided by the inclusion of expert judgment during the different stages involved in the risk evaluation, several uncertainties were recognized as affecting the outcomes. The most significant ones emerge from the degree of data availability and access and the very limited time allocated to the project. The main aspects which could contribute to reducing uncertainties in future assessments include: improving databases and existing landslide inventories as well as harmonizing these and establishing observational 
and monitoring sites for different landslides types in various natural and human-affected environments.

For a proper functioning, scientific services require a stronger connection with the stakeholders from the very start of the project idea, to better understand the beneficiary needs, the practical utility and the expectations regarding the final products. This might be more time consuming but it finally ensures a better quality and applicability of the results. A stronger communication from both sides would enable stakeholders to gain experience in being involved in scientific projects and be aware of the research particularities, and scientists to gain more insights into the real needs and the practical use of their outputs.

\section{ACKNOWLEDGMENT}

The authors wish to thank the coordinating institution and main beneficiary of the project, GIES, and particularly Col. Dr. Francisc Senzaconi, for the good collaboration and the continuous support throughout the project's development, as well as the partner institutions involved in the landslide research: the Technical University of Civil Engineering (UTCB), the National Institute for Research and Development in Constructions, Urban Planning and Sustainable Spatial Development (URBAN-INCERC), the National Institute for Earth's Physics (NIEP) and the National Meteorological Administration (ANM). The study also benefitted from the scientific inputs of Prof. Dănuţ Petrea, Dr. Ştefan Bilaşco (Babeş-Bolyai University, Cluj-Napoca) and Dr. Ciprian Mărgărint ("Alexandru Ioan Cuza" University of Iaşi). The authors appreciate the fruitful collaborations with the Institute of Sociology and the Institute for Economic Forecasting of the Romanian Academy. The entire team of personnel involved in the different parts of the project's assessment is also thanked.

\section{REFERENCES}

[1] W. Mauser, G. Klepper, M. Rice, B.S. Schmalzbauer, H. Hackmann, R. Leemans, and H. Moore, "Transdisciplinary global change research: the co-creation of knowledge for sustainability", Curr. Opin. in Environ. Sustain., vol. 5, no. 3-4, pp. 420-43, 2013.

[2] GIES, "Methodology for risk evaluation and integration of individual risk assessments" ("Metodologia de evaluare a riscurilor si de integrare a evaluărilor de risc sectoriale”),
https://www.igsu.ro/documente/RORISK/Metodologia\%20de\%20evaluare\%20unitara\%20a\%20riscuri lor\%20-\%20versiune\%20finala.pdf, 2016, last accessed April 2017.

[3] GIES, “Country report 5.1 Conditionality. Romania 2016”, https://www.igsu.ro/documente/RORISK/Raport_Final_de_tara.pdf”, 2016, last accessed April 2017.

[4] M.J. Crozier and T. Glade "Landslide hazard and risk: issues, concepts and approach” in Landslide hazard and risk, vol. III, T. Glade, M. Anderson and M.J. Crozier, Eds. Chichester: John Wiley \& Sons, 2005, pp. 1-40.

[5] D. Bălteanu, V. Chendes, M. Sima, and P. Enciu "A country-wide spatial assessment of landslide susceptibility in Romania", Geomorph., vol. 124, no. 3-4, pp. 102-112, 2010.

[6] NIEP, "ROMPLUS Catalogue” (“Catalog ROMPLUS”), http://www.infp.ro/romplus/, 2017, last accessed April 2017

[7] C.S. Dragotă, Precipitațiile excedentare în România. București: Edit. Academiei Române, 2006. (in Romanian)

[8] D.K. Keefer, "Investigating landslides caused by earthquakes - a historical review”, Surv. Geophys., vol. 23, pp. 473-510, 2011.

[9] V. Del Gaudio and J. Wasowski, “Advances and problems in understanding the seismic response of potentially unstable slopes”, Eng. Geol., vol. 122, pp. 73-83, 2011.

[10] M. Jurchescu, D. Micu, M. Sima, D. Bălteanu, C. Dragotă, M. Micu, "An approach to investigate the effects of climate change on landslide hazard at national scale (Romania)”, in Proceedings of the Romanian Geomorphology Symposium, 33d ed., 11-14 May, 2017, Iași, M. Niculiță and M.C. Mărgărint, eds., pp. 121-124.

[11] P.H. Verburg, W. Soepboer, R. Limpiador, M.V.O. Espaldon, M. Sharifa, and A. Veldkamp, "Land use change modelling at the regional scale: the CLUE-S model”, Environ. Manag., vol. 30, pp. 391-405, 2002.

[12] M. Jurchescu et al., unpublished. 


\title{
Landslide inventory of the Crasna catchment, Moldavian Plateau, Romania
}

\author{
Alina Bejenaru, Mihai Niculiţă \\ Department of Geography, Geography and Geology Faculty \\ Alexandru Ioan Cuza University of Iaşi \\ Iaşi, Romania \\ bejenarualina96@yahoo.com, mihai.niculita@uaic.ro
}

\begin{abstract}
Spatial landslide inventories are fundamental elements for landslide spatial susceptibility and landslide hazard modelling. These are digital spatial databases which indicate the spatial presence and the spatial extent of the landslide events or complexes. In the present study we describe the creation and the statistical validation of a landslide inventory for the Crasna catchment, left tributary of the Bârlad river, Moldavian Plateau. In this catchment, with an area of $185.2 \mathrm{~km}^{2}, 1619$ polygons were delineated, representing landslides which have a clear and distinct morphological signature on high resolution DEMs. Beside the DEMs, high resolution imagery from the Google Earth and Bing Maps archives and old and recent aerial images were used to supplement the morphological information. The obtained inventory is a geomorphological one and a historical one because it contains all the landslides, relict, old and recent, that are recognizable in the actual geomorphological context. The criteria for landslide delineation was mainly the morphological one, respectively the presence of any of the following landslide elements: principal and secondary scarps, landslide body with rough topography, bedding traces, landslide foot, tip, toe and flanks. Beside the landslide delineation, the landslide inventory contains data about the typology of the landslide (using the Cruden, Varnes \& Hungr classifications), inferred from the morphology, the landslide age inferred from the geomorphological and topological information of the remote sensing data. The validity of the inventory was tested and argued using the Malamud et al., 2004 landslide area distribution frequency. This shows that the magnitudes of the landslides from the Lohan catchment are distributed in a similar way as landslide magnitude is distributed in other areas of the globe.
\end{abstract}

Keywords- landslide inventory; Crasna catchment; Moldavian Plateau

\section{INTRODUCTION}

Landslides represent a common geomorphologic hazard in the Moldavian Plateau and in the Crasna catchment, landslide being an important geomorphologic process that shapes the landforms. While the area is characterized mainly by rural settlements, many of these settlements are located on hillslopes, where there is protection against the winter winds and floods, but where relict and old landslides are present. Beside the settlements, vulnerable infrastructure is situated in the Lohan catchment: the European 581 road from Huşi to Bârlad and the Huşi-Bârlad railway. While the European road is situated along the floodplain and at the base of the right hillslope, and is not so vulnerable to landslides, the railway runs through the right hillslope of the Lohan valley, being very vulnerable to landslides.

Landslides inventories are the main sources for landslide analysis [1], either for landslide analysis or landslide hazards. Knowing the repartition and the main causes of landslides, has an important role in the risk assessment which is needed for spatial planning in the Crasna catchment.

\section{STUDY AREA}

The Crasna catchment is located in the eastern part of the Central Moldavian Plateau, North-Eastern Romania (Fig. 1).

\section{A. Geology}

The monoclinic strata which has a NW to SE dip and various strikes is of Middle to Upper Miocene age [2]. The majority of the study area has Upper Sarmatian (Kersonian) bedrock, only the upper part of the hillslopes which have altitude beyond $350 \mathrm{~m}$ a.s.l., in the central, north-western and eastern part of the catchment being developed on Meotian rocks. The Kersonian rocks have in the northern and the middle part of the catchment a sandy deltaic facies, while in the lower part of the catchment have a sandy brackish facies. The Meotian rocks have an andesitic cineritic tuff with cineritic sands intercalation base, which is covered by sands, clays and silts. The hillslopes which have at the base and median part the Kersonian sands and the cineritic tuff at the upper part have altitude range over $100 \mathrm{~m}$, and develop a specific morphology, with an upper steep escarpment, where the bedding is visible, and a medium and lower par which is not so steep and is covered by thick landslide deposits and hillslope deposits. Usually these hillslopes are developed as NE to SW alignments, which are not fragmented by valleys.

\section{B. Landforms}

The channel network has a pronounced asymmetry, the tributaries from the right side (Cetăţuia, Gănești, Blăneşti, 


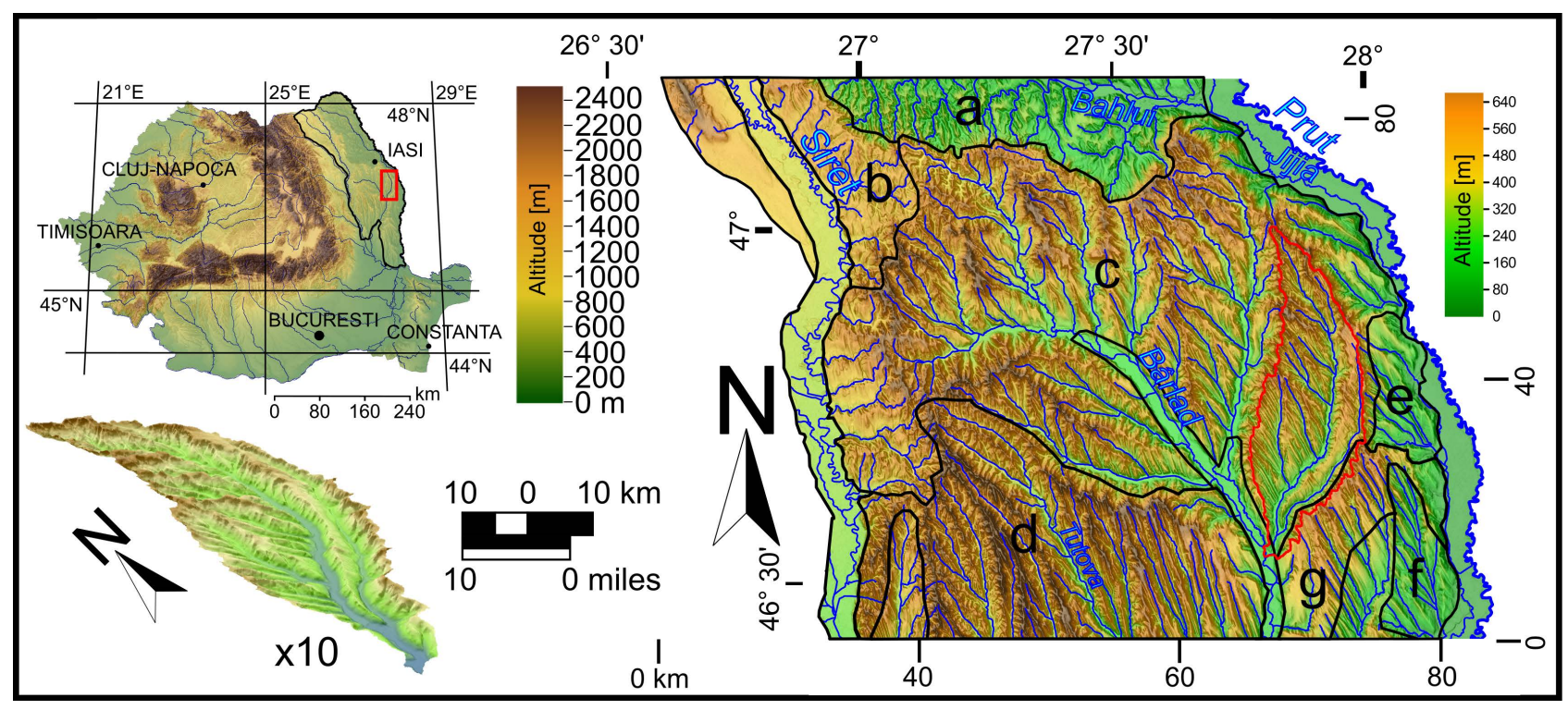

Fig. 1. The geographic position of the Crasna catchment in Romania and in the Moldavian Plateau: a) Jijia Hills, b) Suceava Plateau, c) Central Moldavian Plateau, d) Tutovei Hills, e) Huşi Depression, f) Sărata Depression, g) Fălciu Hills; in the lower left part a tridimensional view of the study area.

Bălţaţi, Burghina - Fig. 3a) being much longer than those form the left side.

This situation happens also for the Lohan catchment, the main tributary of Crasna. This predictive patterns is due to the monoclinic geological structure, which has a NW to SE dip, the main channel network with a NE to SE flow direction suffering a homoclinal shifting toward SE (Fig. 3a).

The floodplains are generally flat, from 200 to $1000 \mathrm{~m}$ wide, and have narrow and not so deep channels (1-2 m). The landforms also present a predictive patterns of asymmetry: hills have usually the NW hillslope steeper and shorter, than the SE hillslope which is gentle and long.

The altitude ranges between $82 \mathrm{~m}$ a.s.l. in south, at the confluence with Bârlad river, to $424 \mathrm{~m}$ a.s.l. in NW. The mean altitude is $221 \mathrm{~m}$ a.s.l., with a standard deviation of $63 \mathrm{~m}$. The altitude range between local valleys and ridges is under $100 \mathrm{~m}$, only along Lohan valley and in the middle sector of Crasna valley this range going up to $150 \mathrm{~m}$, because on the left side of these valleys massive cuesta escarpments appear.

\section{MAterials AND METHODS}

The main source for landslide delineation was a LiDAR DEM with $0.5 \mathrm{~m}$ resolution. Geomorphometric variables (shading, slope, curvatures, slope edge detection) were derived from this DEM and used in the visualization were the landslide delineation was performed. The delineation was performed in Google Earth, in 3D mode, in order to correctly assess the geomorphological situation. Beside the geomorphometric data, Google Earth imagery archive was used to evaluate the landslide elements. Various image acquisition times during the day (morning time images, which have good shades are better than midday time images when the shades are minimal) or during the year (winter, spring and autumn times images, when vegetation is not yet developed and snow might occur in shaded areas are better than summer time, when the vegetation is fully developed) can supplement the morphometric data, in order to assess the presence of escarpments and the roughness of the landslide body. Topographic profiles were also used in order to understand the landslide flow mechanism.

A landslide polygon was delineated (Fig. 2) when at least three of the following landslide elements [3, 4] were found:

- $\quad$ Landslide crown or main scarp;

- Landslide body with secondary scarps and roughness different from the non-slided hillslope;

- $\quad$ Landslide flanks and landslide toe and tip.

For every landslide polygon, after the delineation the following attributes were assigned:

- Landslide type, translational slide, rotational slide, earth flow, spreads and complex;

- $\quad$ Landslide age, relict, old and recent [5].

\section{RESULTS}

In total 1619 landslide polygons were delineated (Fig. 3b). The majority of the landslides are relict or old complex landslides, with translational/rotational reactivations on the scarp and on the landslide body. These complex landslides, beside the complex typology of the movement are not the result of a single event, but are the result of multiple events, which usually generated the extension of the landslide processes along the entire hillslopes, bot laterally and along the slope [2, 6]. These complex landslides can be characterized either by or by big dep seated events, followed by scarp reactivations.

The majority of the individual landslides (which are not reactivations) are old or recent age translational landslides. Rotational and earth flows having old or recent age represent under $20 \%$ of individual landslides.

The spatial distribution of the landslides, revealed by the landslide index (Fig. 3c) [7] show a spatial clustering of the complex and individual landslides along the steep cuesta escarpments along the main rivers. 


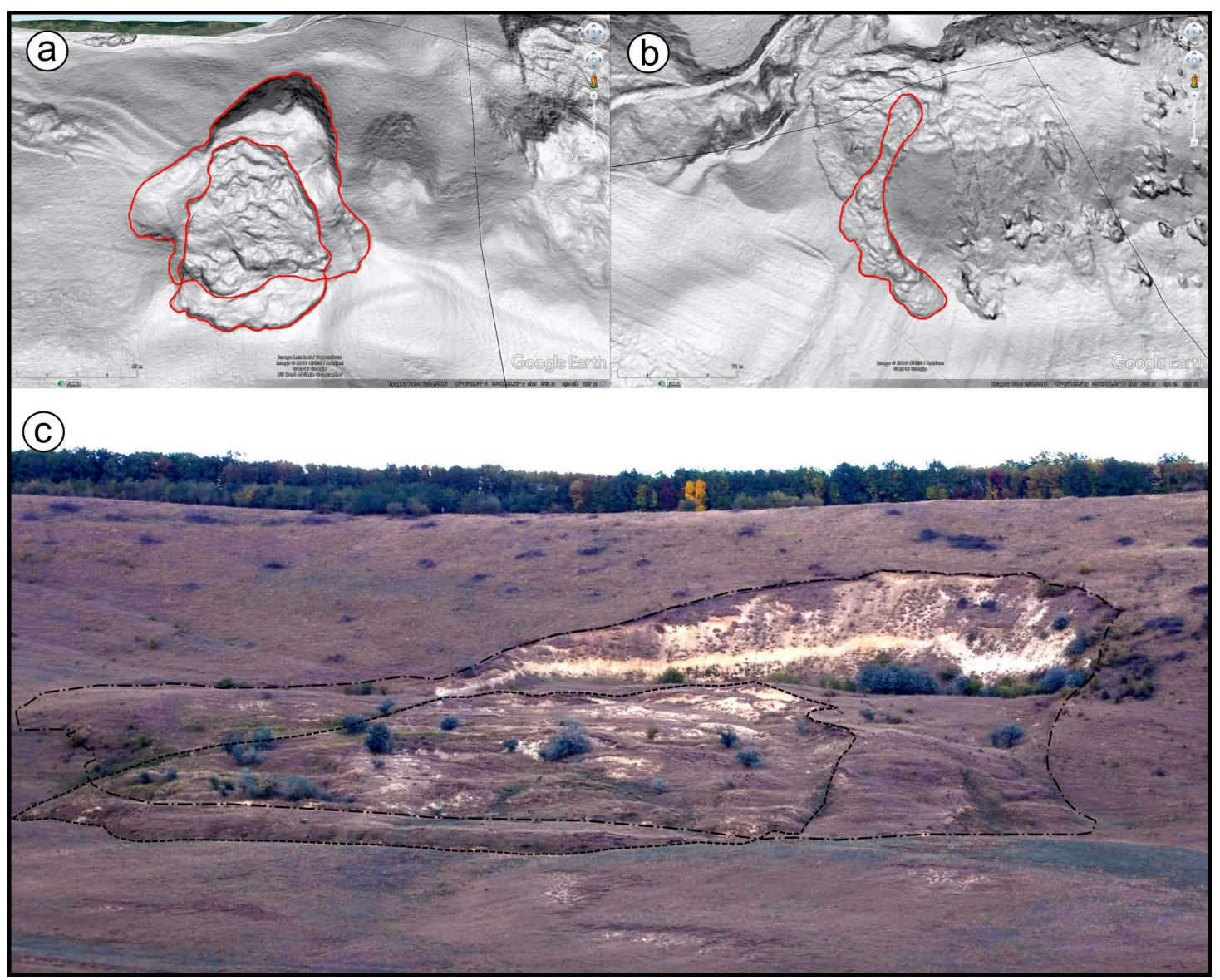

Fig. 2. Examples of delineated landslides: a - shaded view of a rotational landslide affected by a translational landslide, b - shaded view of an earth flow, c - field situation with the landslides from a.

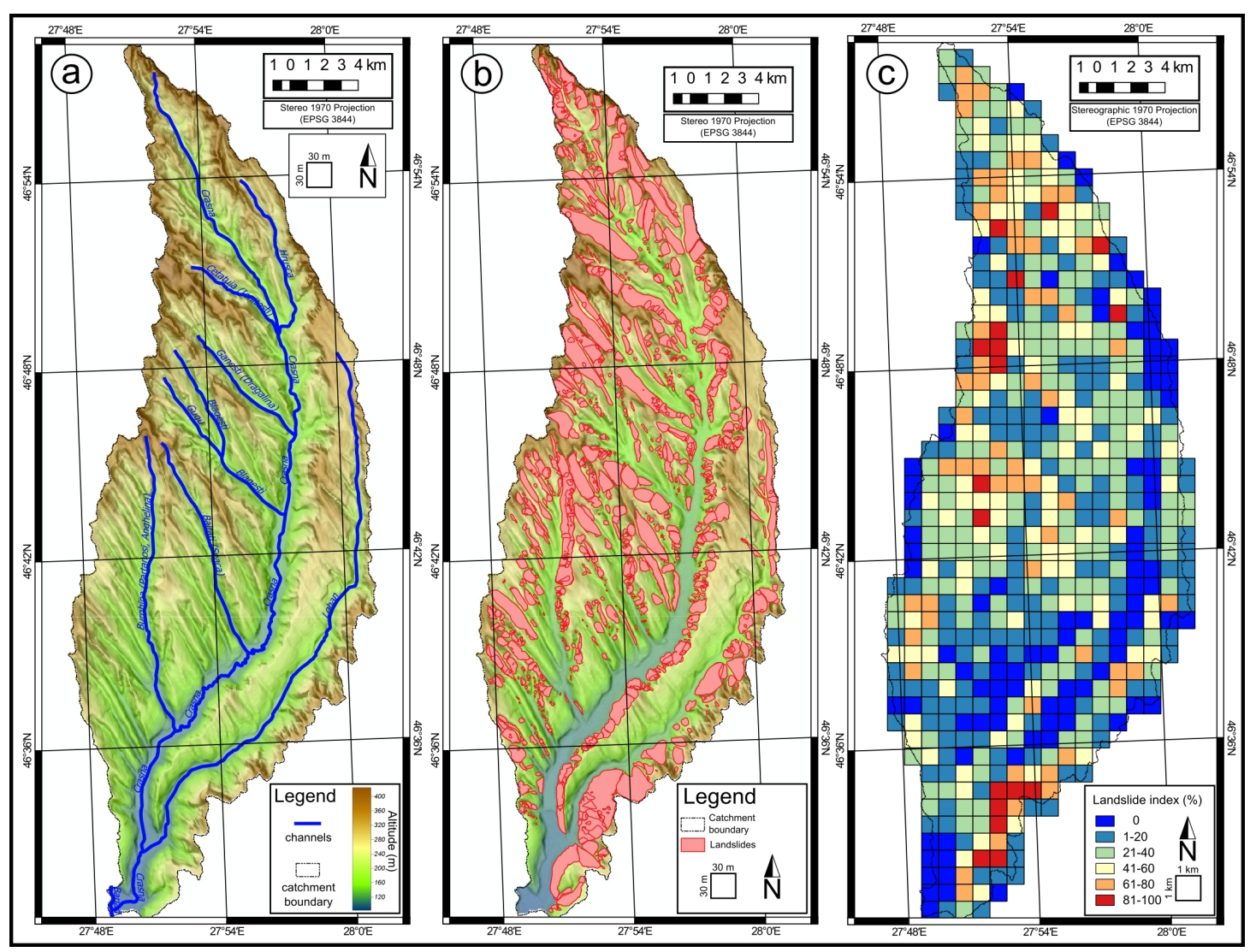

Fig. 3. Hipsometry (a), landslide inventory (b) and landslide index (c) of Crasna catchment. 
The biggest clusters of landslides are located where the amplitude of the altitude is highest along these steep slopes: the left hillslope in the lower part of Lohan catchment and the upper part of Găgești catchment, showing that the fluvial incision controlled the landsliding.

Gentle cuesta dip slopes are affected by landslides, only where the drainage network is incised. The landslides from these areas are also complex landslides, fact that we believe that argue a quick incision.

In the upper part of the Crasna valley, because of the symmetry of the valley profile, the landslide density increase on both hillslopes, which is believe is also generated by the river incision.

\section{Discussions}

To check the validity and the completeness of the inventory we have analyzed the frequency distribution of the landslide area (Fig. 4) [8, 9, 10]. Although the distribution has an inverse gamma shape, it is different than other historical landslide inventories, by the slope of the tail, mainly because the use of LiDAR data allowed us to delineate every complex landslide. These complex landslide have big surface, which spans two orders of magnitude. In this part of the curve, the landslide magnitude is overestimated. In the same time in the smaller landslides part of the curve, compared with previous results in the Moldavian Plateau [2,5] the inventory is complete. This result show that when LiDAR data is used in conjunction with high resolution aerial imagery for landslide delineation, a higher number of landslide events can be delineated.

\section{CONCLUSIONS}

The landslide inventory of the Crasna catchment represent a first crucial step toward landslide hazard and risk assessment. The analysis of the typology and spatial distribution of landslides form the inventory show the control of landforms and river incision on landslide development. The area distribution analysis show that while the LiDAR data is useful for complete characterization of small and mean magnitude individual landslides, the complex landslides are a feature which characterize the Moldavian Plateau, which need further study in order to assess the characteristic size of the biggest magnitudes.

\section{ACKNOWLEDGMENT}

We are grateful to Prut-Bârlad Water Administration who provided us with the LIDAR data. We have used the computational facilities given by the infrastructure provided through the POSCCE-O 2.2.1, SMIS-CSNR 13984-901, No. 257/28.09.2010 Project, CERNESIM (L4).

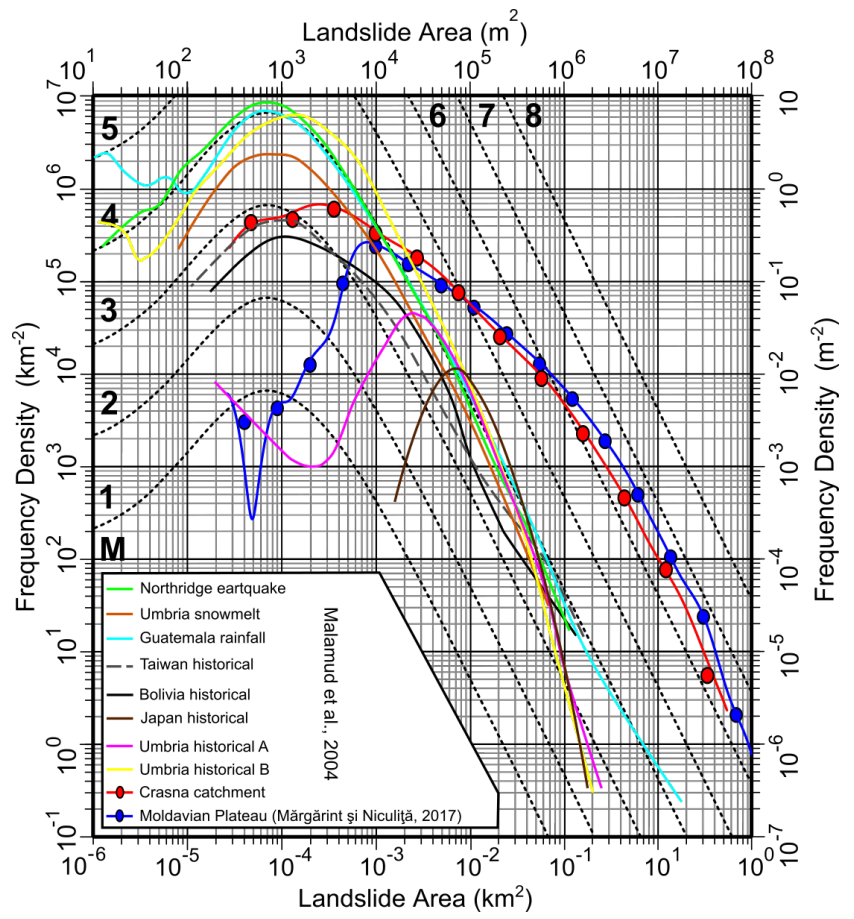

Fig. 4. The landslide frequency density curve for the Crasna catchment, for the Moldavian Plateau [2], and for other areas in the world [8, 9]

\section{REFERENCES}

[1] F. Guzzetti, A.C. Mondini, M. Cardinali, F. Fiorucci, M. Santangelo, and K.-T. Chang, "Landslide inventory maps: New tools for an old problem,” Earth-Science Reviews, vol. 112, pp. 4266, 2012.

[2] M.C. Mărgărint and M. Niculiță "Landslide type and pattern in Moldavian Plateau, NE Romania,” in M. Rădoane and A. Vespremeanu (eds.) Landform Dynamics and Evolution in Romania, Springer, 2017, pp. 271-304.

[3] D.M. Cruden and D.J. Varnes, "Landslide types and processes" in Landslides investigation and mitigation, Transportation Research Borad, US National Council, Special Report 247, A.K. Turner and R.L. Schuster, Eds. Washington DC: 1996, pp. 36-75.

[4] O. Hungr, S. Leroueil, and L. Picarelli, "The Varnes classification of landslide types, an update”, Landslides, vol. 11, no. 2, pp. 167194, 2014.

[5] M. Niculiţă, M.C. Mărgărint, and M. Santangelo, “Archaeological evidence for Holocene landslide activity in the Eastern Carpathian lowland,” Quaternary International, vol. 415, pp. 175-189, 2016.

[6] M. Niculiţă and M.C. Mărgărint, "Landslide inventory for the Moldavian Plateau," in Proceedings of the international conference Analysis and management of changing risks for Natural Hazards, 18-19 Nov. 2014, Padua, Italy, http://www.changesitn.eu/Portals/0/Content/2014/Final\% 20conference/ abstracts/AP3_Abstract_Niculita.pdf.

[7] A. Trigila, C. Iadanza, and D. Spizzichino, "Quality assessment of the Italian Landslide Inventory using GIS processing” Landslides, vol. 7, pp. 455-470, 2010.

[8] B.D. Malamud, D.L. Turcotte, F. Guzzetti, and P. Reichenbach, "Landslide, earthquakes, and erosion," Earth Planet Sci Lett, vol. 229, pp. 45-59, 2004.

[9] B.D. Malamud, D.L. Turcotte, F. Guzzetti, and P. Reichenbach, "Landslide inventories and their statistical properties," Earth Surf Proc Landf, vol. 29, pp. 687-711, 2004.

[10] M. Rossi, M. Cardinali, F. Fiorucci, I. Marchesini, A.C. Mondini, M. Santangelo, S. Gosh, D.E.L. Riguer, T. Lahousse, and K. Chang, F. Guzzetti "A tool for the estimation of the distribution of landslide area in R,” Geophysical Research Abstracts, Vol. 14, EGU2012-9438-1, 2012. 


\section{The Oprăneşti landslide (Mehedinţi county) - evaluation, impact, solutions}

\author{
Sandu Boengiu, Oana Mititelu-Ionuş, Claudia Albă \\ Geography Department \\ University of Craiova \\ Craiova, Romania
}

\author{
Daniel Simulescu \\ Institute of Geography \\ Romanian Academy \\ Bucharest, Romania
}

\begin{abstract}
On May 24, 2016, in Husnicioara commune (Mehedinţi county) the county road 607A (Cerneţi-Prunişor), communal road 17A (which connects to Oprăneşti village) and the electricity transport network were affected by landslides. Because of the landslide and the associated processes there were damaged both roads, embankments and all other previously built elements for the slope's stabilization, taking off the water from rainfall, combat and mitigate erosion (cassettes, supporting walls, concrete ditches, tailboards etc.). The damage to the road network consisted in the destruction of some sectors from county road 607A on a length of $443 \mathrm{~m}$ and communal road 17A on a length of $131 \mathrm{~m}$. The terrain reconfiguration which occurred because of the horizontal and vertical movements, locally destroyed the electricity transport network by collapse the supporting pillars of electric cables. Field measurements carried out from 2 to 16 June 2016 with GPS South S-82T were processed using GIS techniques and obtaining the numerical model of the landslide. After corroborating field analysis with the thematic maps resulted from the overlapping of the layers specific to the relief, lithology, land use/cover, it was established that the whole sectors affected by the landslide (DJ 607A and DC 17A) were destroyed, and that is impossible to restore them on the current emplacement. Taking into account the physical, geographical and territorial distribution of human settlements, for the reopening of DJ 607A there were identified and proposed as solutions two different routes with low risk and vulnerability to landslides.
\end{abstract}

Keywords - landslide; road network; GIS; vulnerability; Oprăneşti village

\section{INTRODUCTION}

Much of the world's road and railway network is built on embankments or in cuttings, thus, being susceptible to disruptions caused by landslides. The blockage of one or more roads by landslides can cause extensive detours and the delay of rescue and recovery operations, in those regions [1].

Although the modern civil engineering capabilities can rapidly repair the damages produced by landslides, the economic consequences of severing a major transport artery for even a short period can far outweigh the remedial costs [2].
The accurate evaluation of topographic attributes acquired with geo-referencing is an important element for the delineation and characterization of landslides [3, 4]. Positioning based on GPS satellites allows a faster localization of the attributes required for geomorphologic studies, unpublished $[5,6]$. Also, field surveys are focused to estimate qualitatively damages along these roads [7]

\section{STUDY AREA}

In Husnicioara commune, the county road 607A (Cerneţi - Prunişor), the communal road 17A (which connects to Oprăneşti village) and the electricity network were affected by mass movements in the spring of 2016. The county road 607A was affected by a landslide and other associated processes, on a length of $443 \mathrm{~m}$ (Fig. 1).

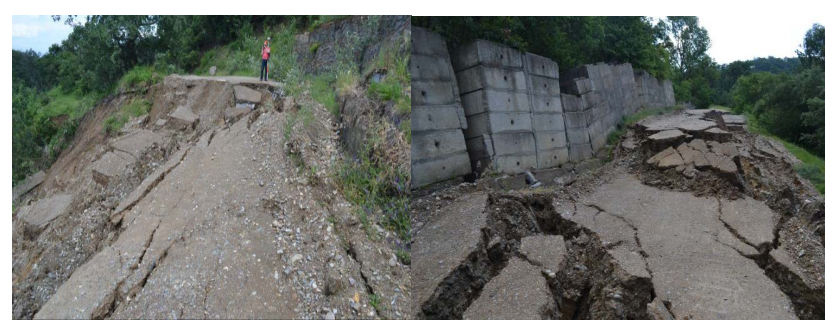

Fig. 1. DJ 607A: 1-3 m vertical displacement (left); random deformation of the road, embankments and rockfill supporting cassettes, displacement in the plane of $150 \mathrm{~m}$ (right) (Photo by Boengiu S., 16.06.2016)

The associated processes to the landslide are areas of compaction with high amplitude, collapse of large masses of material, the tilting of the packages of lithological layers left undisturbed or strongly disturbed as against their sequence and original position, the appearance of fissures and cracks with variable depths and openings, the destruction of the vegetation layer.

The communal road 17A was affected by the same landslide of a length of $131 \mathrm{~m}$, bearing the same types of processes.

The electricity network, which crossed the slided mass, was affected by the topographical reconfiguration occurred due to the horizontal and vertical movements. These led to the collapse of the pillars which supported the electric cables. 


\section{DATA AND METHODS}

Field measurements were made between 2 and 17 June 2016 using GPS South S82-T. Measurements carried out on 02.06.2016 were repeated on 16.06.2016, ascertaining the changes both horizontally and vertically. After completing the field stage it was passed to transfer the points measured with GPS in ArcCatalog.

Corrections of the field measurements were made using orthophotos, scale 1:5,000, and topographic map, scale 1:25.000, and then transposed the vector basis tot raster using 3D Analist toolbox (Features to Raster and Raster to TIN).

On the basis of a $5 \times 5 \mathrm{~m}$ network grid the numeric model of the landslide was made [8], which was then visualized in 3D using ArcScene (Fig. 2).

The digital numeric model was made using field measurements (297 points).

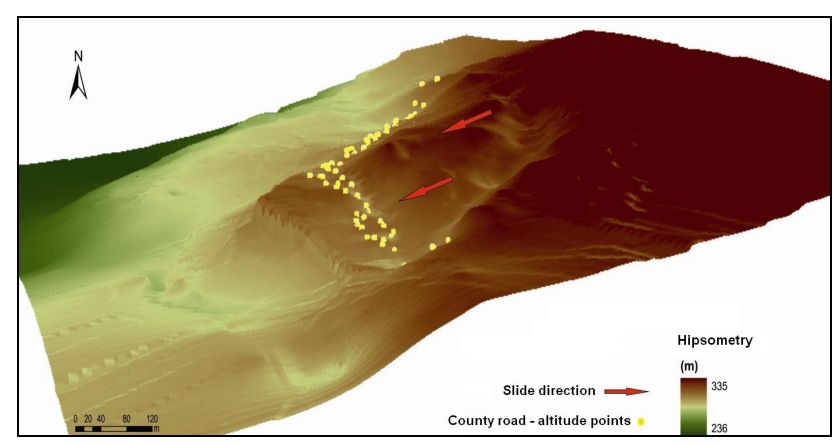

Fig. 2. The numeric model of the study area emphasizing DJ 607A (measurements and processing - June 2016).

In order to obtain the slope and slope orientation maps it was used the Spatial Analyst toolbox (Contour, Slope and Aspect) from ArcMap, with its help being achieved the landslide susceptibility map [9].

\section{RESULTS}

Changes caught between the two stages of measurements (02 and 16 June 2016), present an evolving situation. In the first stage there was a detachment with predominance of vertical movements which led to subsidence and tilting of the prism but not disturbing the lithological suite, and subsequently the movement became rotational, leading to differences in the prism's mass, its cracking and breaking in different directions, mostly to the neighboring torrential body.

For deciphering the mechanisms that contributed to occurrence of landslides and their associated processes, there were analyzed the geological (structure, lithology), geographical (relief, climate, hydrography, vegetation and soils) and anthropic components (underground exploitation of lignite) [10].

Obtaining the specific relief maps using the GPS measured point in the field confirm the vulnerability of the area (the area between Oprănești - Marmanu - Dudovița Veche - Valea Copcii localities) to landslides.

Thus, according to the hypsometry map, altitudes decrease from east to west, registering a maximum altitude of $375 \mathrm{~m}$ and a minimum of $157 \mathrm{~m}$, resulting a maximum amplitude of $218 \mathrm{~m}$; the slope map outlines geodeclivity values between 0 and 1.27, areas with higher geodeclivities are distributed mainly in the west and north, and in the east the common values are close to 0 .

The susceptibility map to landslides was drawn by overlapping slope map, slope orientation map, soils map and land use/cover map.

The landslide susceptibility values were classified on a scale from 0 (which represents a low susceptibility to landslides), to 9 (which is a high susceptibility to landslides).

A triggering component of these landslides is the undermining of the slope in the southern part by some torrential bodies that have deepened their thalweg and regressively advanced due to higher amounts of precipitation and friability of the deposits. This fact is suggested by the higher amount of material mobilized in this area, the direction of the glided materials being different from the orientation of the slope.

In conclusion, from the field observations and analysis of lithology sequence, the sand and gravels layers with thickness over $100 \mathrm{~m}$ allowed the easy infiltration of waters coming from rain and the successive moistening of clay layers at depths of approximately $40 \mathrm{~m}$. This moistening was made due to the permeability of the sands found above the clays and the above average rainfall recorded in the autumn of 2015 and in January (snow) and March-April 2016.

\section{CONCLUSIONS}

Following the complex analysis performed, taking into account the morphology of the landslide from the spring of 2016 and knowing the general behavior of gravitational processes and local conditions, we can issue the following conclusions of the road sector affected by the landslide and even anticipate further development:

- the terrain surface was strongly modified, the vertical amplitudes recording over $24 \mathrm{~m}$ while the horizontal ones 4-6 m ;

- the morphology and functionality of the slope has been changed, increasing the vulnerability to mass movements ;

- the road sectors that belong to DJ 607A and DC 17A are completely destroyed ;

- restoring the roads on the current location is no longer possible, given the risks to gravitational and old hydric processes that were greatly accentuated by recent events ;

- the temporary road towards Oprăneşti village is in the area with high landslide susceptibility and will face the same processes which led to the destruction of DJ 607A and DC 17A;

- this landslide will continue to evolve and expand until the slope will mitigate and the thresholds specific to the local lithology will not be exceeded.

As a solution to ensure and establish the connection between localities, the mitigation and stopping the gravitational processes, it was identified and proposed a new route to reopen DJ 607A which, even it is longer, it presents low risks and vulnerabilities: Oprănești Marmanu - Dedovița Veche - Valea Copcii. Another 
advantage of the new route is that it facilitates access of Marmanu and Dedoviţa Veche localities to a modernized road.

The sectors with higher slope of this road are already functional as communal paved roads, and the new part of the road which must be built crosses a quasi-horizontal plateau, without natural or anthrophic obstacles.

\section{REFERENCES}

[1] F.E. Taylor, B.D. Malamud, M. Santangelo, I. Marchesini, and F. Guzzetti, "Statistical Patterns of Triggered Landslide Events and their Application to Road Networks", in EGU General Assembly Conference Abstracts, vol. 17, p. 9992, April 2015.

[2] D.M. Lloyd, M.G. Anderson, A.N. Hussein, A. Jamaludin, and P.L. Wilkinson, P. L., "Preventing landslides on roads and railways: a new risk-based approach", in Proceedings of the Institution of Civil Engineers-Civil Engineering, Thomas Telford Ltd, vol. 144, no. 3, pp. 129-134, August 2001.

[3] C.M. Feo, L.M. Martinez, and N.C. Munoz, Accuracy and Spatial Variability in GPS Surveying for Landslide Mapping on Road Inventories at a Semi-Detailed Scale: the Case in Colombia, 2016.

[4] M. Popescu, R.D. Serban, P. Urdea, and A. Onaca, "Conventional geophysical surveys for landslide investigations: two case studies from Romania”, Carpathian Journal of Earth and Environmental Sciences, vol. 11, no. 1, pp. 281-292, 2016.
[5] S. Boengiu, D. Simulescu, and O. Ionuș, "The evolution of Breasta landslide (The Getic Piedmont, Romania). The GPS monitoring of landslide and induced risks”, The 15th Joint Geomorphological Meeting (JGM) „Fluvial and coastal systems in tectonic active areas”, 1-4 June 2011, Athens, Greece (unpublished).

[6] F. Fiorucci, M. Cardinali, R. Carl, M. Rossi, A.C. Mondini, L. Santurri, and F. Guzzetti, "Seasonal landslide mapping and estimation of landslide mobilization rates using aerial and satellite images”, Geomorphology, vol. 129, no. 1-2, pp. 59-70, 2016.

[7] P. Salvati, M. Donnini, F. Guzzetti, F. Ardizzone, M. Cardinali, F. Bucci, F. Fiorucci, M. Alvioli, and M. Santangelo, "Impact of landslides along road network and direct cost estimation: A case study in Marche Region, Central Italy", in AGU Fall Meeting Abstracts, vol. 1, p. 08, December 2014.

[8] I. Armaş, F. Vartolomei, F. Stroia, and L. Braşoveanu, "Landslide susceptibility deterministic approach using geographic information systems: application to Breaza town, Romania”, Natural Hazards, vol. 70, no. 2, pp. 995-1017, 2014.

[9] O. Ionuş, M. Licurici, S. Boengiu, D. Simulescu, and E. Marinescu, "Landslide-susceptibility analysis, mapping and validation in the Bălăcița Piedmont (South-West Romania)", The 32nd International Geographical Congress, 26-30 August 2012, Cologne Germany (unpublished).

[10] S. Boengiu, O. Ionuş, and E. Marinescu, "Man-made changes of the relief due to the mining activities within Husnicioara open pit (Mehedinţi County, Romania)", Procedia Environmental Sciences, vol. 32, pp. 256 - 263, 2016. 


\section{Monitoring and segmentation of 10 caves from the Pădurea Craiului Mountains in order to ensure conservative management. Case study: Ciur Ponor Cave}

\author{
Nicolae Cruceru \\ Department of Informatics - Geography, \\ „Spiru Haret“ University, \\ Bucharest, Romania
}

\author{
Nicolae Cruceru, Alexandru Petculescu, Rodica \\ Plăiașu, Ioana Meleg, Augustin Nae, Cristian- \\ Mihai Munteanu, Luchiana Faur, Daniela Cociuba \\ (Borda), Eugen Nițu, Marius Vlaicu, Marius Robu \\ Emil Racoviță Institute of Speleology \\ Romanian Academy \\ Bucharest, Romania
}

\begin{abstract}
The selected caves were monitored to establish management plan for speo-tourism. Several aspects were taken in consideration, among these the biology, geology, climatology, geo-morphology, paleontology and archeology of each cave. Our study is the result of several monitoring stages and it evaluates the thermic characteristics of air, carbon dioxide content, water temperature, quantity of oxygen dissolved in water, evaluation of biodiversity, evaluation of fossil bones deposits and monitoring of underground risk factors. We made propositions for sectors with integral conservation and sectors where speleo-tourist activities are allowed. The selected caves were monitored to establish their sections and finishing the management plan for speo-tourism. Several aspects were taken in consideration, among these the biology, geology, climatology, geomorphology, paleontology and archeology of each cave.
\end{abstract} class

Keywords - cave; monitoring; sectorization; protection

\section{INTRODUCTION}

The karstic environments represent complex organized systems, distinguished through the endo- and exokarstic landscape and their capacity to archive information about paleoclimate, archeo-paleontology, sedimentology, morphology etc. Environmental conditions, lithological typology, drainage mode, generate a type of relief which can be valued in various ways. The underground environments represent real "data bases" for science and this is why some caves or caves sectors are destined only for conservation and systematic scientific research and are restricted to the public. On the other hand, caves with local importance, without unique elements, can be used for activities such as cave tourism or mass tourism.

\section{STUDY AREA}

Pădurea Craiului Mountains have a high speleological potential, a number of 1300 caves being reported from this area. From these, we studied 10 caves (Craiului, Gruețului, Hârtopul Bonchii, Ciur Ponor - Toplița de Roșia, Doboș, Osoi, Bătrânului, Vântului, Gălășeni) using a multidisciplinary approach.

Ciur Ponor Cave lies in the karstic complex which includes Ciur Izbuc cave-Ciuc Ponor Cave- Izbucul Toplita localized in Pădurea Craiului Monutains, Natura 2000 Site Defileul Padurea Craiului, respectively.

The site is under the administration of Bihor`s Center for Protected Areas and Sustainable Development, and is included in a category of Reservations and nature Monuments under the Law No.5/2000, with modifications. The cave lies in tectonic limestones, its position is accessible and the morphological variation of the karstic system, determined by the local tectonics which generated the development in big part on diaclase. It has two levels, one active, the other, hydrogeological inactive which resembles a dendritic underground network, rich with erosion and corrosion forms.

\section{Methods and Results}

Our study is the result of several monitoring stages and it evaluates the thermic characteristics of air (Fig. 1), carbon dioxide content (2830 ppm in Vestiarul 1), water temperature, quantity of oxygen dissolved in water (Tab. 1), evaluation of biodiversity (terrestrial and aquatic), evaluation of fossil bones deposits and monitoring of underground risk factors. Also, an inventory of the bat species was made, along with determination of numerous invertebrate species, part of them endemic for the area. In Ciur Ponor Cave the pollution has low levels (the cave does not shelter a large colony of bats, only five species, 
found occasionally, have a communitary importance and they do not form birth or hibernation colonies). We, also, evaluated the characteristics of fissile bone deposits of Ursus spelaeus, found on Tributary 1 .
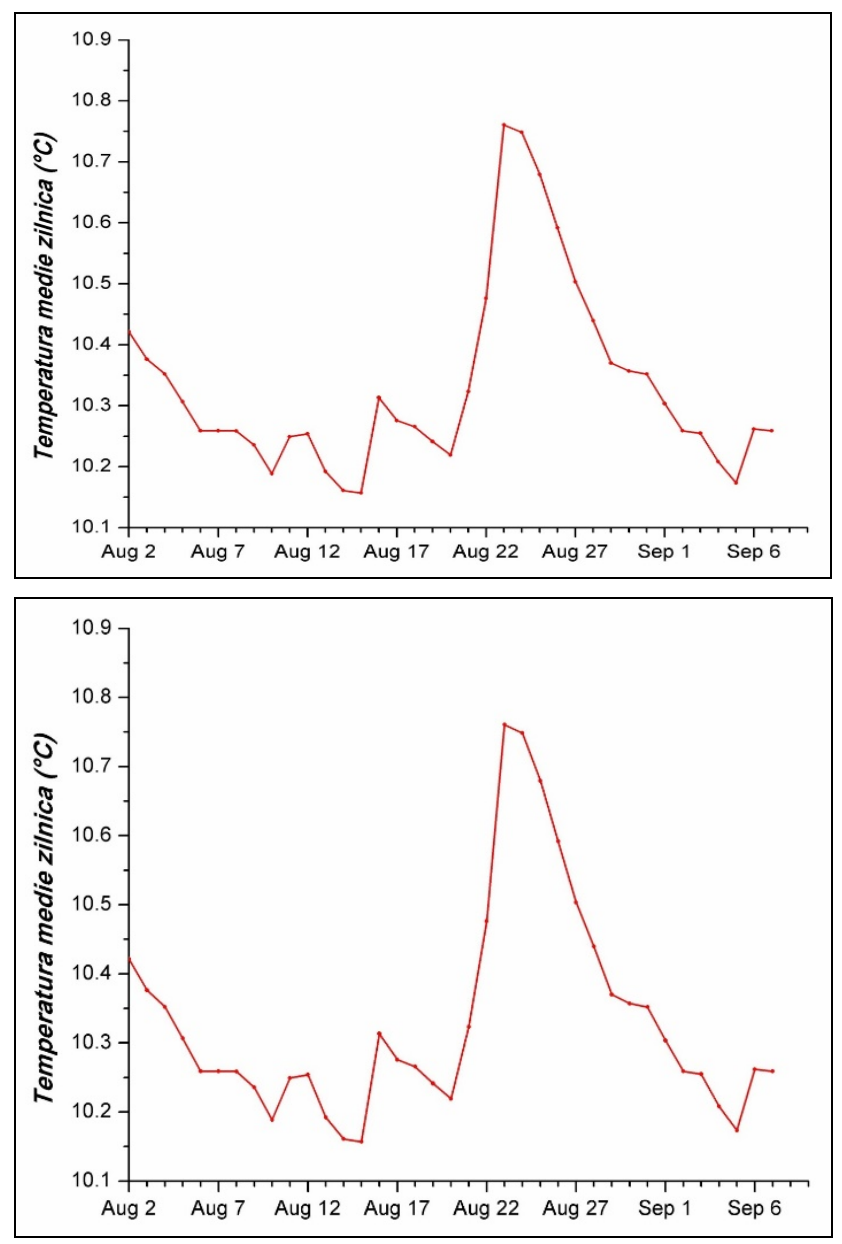

Fig. 1 The average daily temperature variation in the Ciur Ponor Cave: Station 1; in the monitoring interval between 02.08.2016 and 07.09.2016 (up) Station 2, in the monitoring interval between 02.08.2016 and 20.11.2016 (down) highlights the influence of external

TABLE I. PHYSICAL AND CHEMICAL PARAMETERS OF THE RIVER IN CIUR PONOR CAVE

\begin{tabular}{|c|c|c|c|c|c|c|c|}
\hline $\begin{array}{l}\text { Ciur } \\
\text { Ponor } \\
\text { Cave }\end{array}$ & $\begin{array}{c}\mathrm{T} \\
\left(\mathrm{t}^{\circ} \mathrm{C}\right)\end{array}$ & $\begin{array}{c}\mathbf{R} \\
(\mathbf{k} \boldsymbol{\Omega} / \\
\mathbf{c m})\end{array}$ & $\begin{array}{l}\mathrm{C} \\
(\mu \mathrm{S} / \\
\mathbf{c m})\end{array}$ & $\begin{array}{c}\text { TD } \\
\text { S } \\
\text { (pp } \\
\text { m) }\end{array}$ & $\begin{array}{c}\text { Salt } \\
\text { level } \\
\text { (SSE) }\end{array}$ & $\begin{array}{c}\text { Disolved } \\
\text { Oxigen } \\
\text { (mg/L) }\end{array}$ & $\mathbf{p H}$ \\
\hline $\begin{array}{l}\text { Water } \\
\text { course } \\
\text { under } \\
\text { the } \\
\text { gate } \\
\text { (A1 - } \\
\text { uphill) }\end{array}$ & $\begin{array}{l}16 . \\
25\end{array}$ & 5.3 & 156 & 94 & 0.09 & 18.33 & $\begin{array}{l}5 . \\
57\end{array}$ \\
\hline $\begin{array}{l}\text { Water } \\
\text { course } \\
\text { before } \\
\text { first } \\
\text { waterfa } \\
\text { ll (A2 - } \\
\text { downhi } \\
\text { ll) }\end{array}$ & $\begin{array}{l}11 . \\
59\end{array}$ & 5 & 148 & 99 & 0.09 & 19.9 & $\begin{array}{l}5 . \\
55\end{array}$ \\
\hline
\end{tabular}

The cave is Class A protected area, with high scientific interest and unique resources, representative for the speleological national and international heritage.
We made the following propositions for: - sectors with integral conservation (all galleries and rooms from Tributary 1, the galleries and rooms network downhill of siphon/draintrap after Sala Paragină (Topliţa of Roşia), all galleries and rooms which form the tributary upstream Cascada Mare) (Fig. 2);

- sectors where speloeo-touristic activities are allowed (the cave system between the cave entrance and the first siphon after Sala Paragină of the main underground stream). This sector includes the Entry, The Waterfall -4 The Waterfall $-10 \mathrm{~m}$ with a plan of activities and permanent monitoring of the cave (checks on topoclimate, water and air quality, monitoring of underground fauna, monitoring of visits).

In this sector of the cave speleo-touristic activities are allowed, in small groups, with trained guides and suitable equipment that uses only temporary arrangements for safety reasons, in accord with the Management Plan and Regulations.

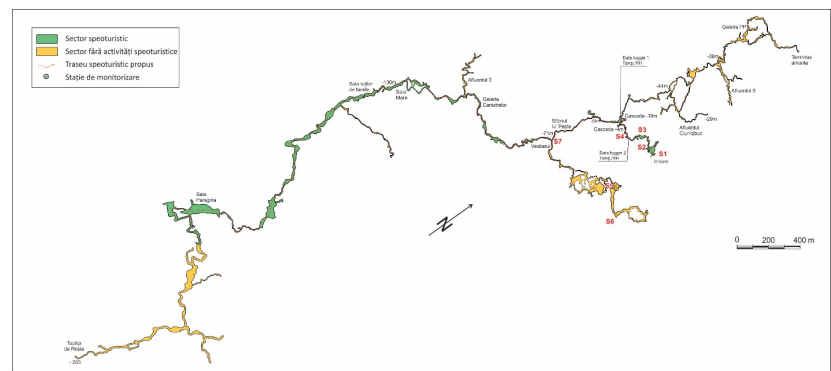

Fig. 2 Ciuc Ponor cave map with proposal for tourism sectorization and positioning of stations for temperature, humidity and aeromicroflora measurements

\section{ACKNOWLEDGMENT}

The study was carried out with the support of the Swiss-Romanian Cooperation Program (SWISS contract 03/2016).

\section{REFERENCES}

[1] M. Bleahu, V. Decu, Ş. Negrea, C. Pleşa, I. Povară, and I. Viehmann, Peşteri din România. Ed. Ştiinţifică şi Enciclopedică, București, 415 p., 1976. (in Romanian)

[2] C. Borda and D. Borda, "Airborne microorganisms in show caves from Romania”, Trav. Inst. Spéol. «Émile Racovitza» vol. XLIII XLIV, pp. 65-74, 2006.

[3] D. Borda and C. Borda, Liliecii - Relații cu omul şi mediul înconjurător, Ed. Napoca Star, Cluj-Napoca, 212 p., 2008. (in Romanian)

[4] I.N. Meleg, M. Năpăruş, F. Fiers, H.I. Meleg, M. Vlaicu, and O.T. Moldovan, "The relationships between land cover, climate and cave copepod spatial distribution and suitability along the Carpathians”, Environmental Conservation, vol. 41, pp. 206-216, 2014.

[5] I.N. Meleg, V. Zakšek, C. Fišer, B.S. Kelemen, and O.T. Moldovan, "Can environment predict cryptic diversity? The case of Niphargus inhabiting Western Carpathian groundwater", PLoS

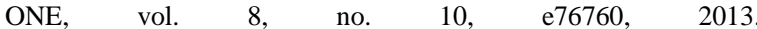
doi:10.1371/journal.pone.0076760

[6] O.T. Moldovan Coleopterele subterane, în: G. Racovită, O.T. Moldovan and B.P. Onac (eds.): Monografia carstului din Munții Pădurea Craiului. Presa Universitară, Cluj, 2002, pp. 165-171. (in Romanian)

[7] B.P. Onac, "Mineralogy of speleothems from caves in Pădurea Craiului Mountains (Romania), and their palaeoclimatic significance”, Cave Science, vol. 24, no. 3, pp.109-124, 1996. 
[8] C. Pleşa, M. Pintea-Alb, I. Sălăjan, and F. Wild, “Date noi asupr ecologiei şi răspândirii geografice a ciclopidelor (Crustacea, Copepoda) în România”, Lucrările Institutului de Speologie „Emil Racoviţă”, vol. 4, pp. 141-154, 1965. (in Romanian)

[9] Planul de management pentru speciile Rhinolophus ferrumequinum, Rhinolophus hipposideros, Myotis myotis, Myotis oxygnathus (blythii); Myotis bechsteinii, Barbastella barbastellus și Miniopterus schreibersii, realizat în proiectul Life08 NAT/RO/000504, aprobat prin OM 656/28.04.2014. (in Romanian)

[10] G. Racoviţă, Elemente de speologie ştiinţifică, f. 3. Climatologie subterană, ISBB \&CC-UTC, 1985. (in Romanian)
[11] G. Racoviță, O.T. Moldovan, and B.P. Onac (eds.), Monografia carstului din Munții Pădurea Craiului. Ed. Presa Universitară Clujeană, Cluj-Napoca, 264 p., 2002. (in Romanian)

[12] M. Vlaicu, C. Jere, A. Dragu, D. Borda, C. Goran, F. SzodorayParádi, R. Năstase-Bucur, E. Niţu, and D. Murariu, Ghid pentru monitorizarea stării de conservare a peşterilor şi speciilor de lilieci de interes comunitar din România. Ed. Advertising, București, 134 p., 2013. (in Romanian) 


\title{
Relief suitability for Ploiești - Pașcani fast road construction
}

\author{
Robert Dobre \\ Geomorphology - Pedology - Geomatics Department \\ Faculty of Geography, University of Bucharest \\ Bucharest, Romania
}

\begin{abstract}
Ploiești - Pașcani fast road one of the most important infrastructure project in Romania. Based on the economic and environmental indicators generated by the National Transport Model used in the General Master Plan for Transport (MPGT) in Romania, resulted that the project is a priority transportation of our country. The estimated length is $327.5 \mathrm{~km}$ and total value for the full implementation of the project is 1304.41 mil. euro without VAT. The implementation period will be five years (two years to achieve technical and economic documents, feasibility study and technical project and four years for work execution).
\end{abstract}

Keywords - fast road; technical solution; geomorphology; geomorphotechnique analysis

\section{INTRODUCTION}

Currently, the Ploiești, Buzău, Focșani, Bacău and Pașcani municipalities are connected by the DN2 national road and DJ208 county road, whose capacity is exceeded on several sectors where traffic speed is limited either by the conditions of relief.

\section{LOCATION OF THE ACTION}

Ploiești - Pașcani fast road is located approximately in the east of the country. The analysis was focused on the first critical sector, one of Ploiesti and Buzau, $65 \mathrm{~km}$ length. A detailed (geomorphological and geomorphotechnique) analysis is absolutely necessary because of the geological context and because of geomorphological peculiarities [1].

\section{SCOPE AND OBJECTIVES}

We were used detailed analysis made in the field in conjunction with GIS techniques analysis, in order to establish the required types of construction solutions needed in order to build the project (road junctions, bridges, culverts, road crossing, railroad overpass , railroad overpass, intersections overhead electrical lines, deposit demolition ) (Fig. 1, Tab. 1).

From the field and laboratory analysis, we identified several critical areas between Ploiesti and Buzau in terms of geomorphology, which can be overcome through arrangements for the protection and defense. These critical areas should be identified and reported from initial feasibility study and technical project in order to establishment of adequate alternative and the measures necessary for subsequent operation [1].

TABLE I. STRUCTURES IDENTIFICATION

\begin{tabular}{|c|c|}
\hline Length $(\mathrm{km})$ & 75.80 \\
\hline Number of road junctions & 6 \\
\hline Number of bridges & 6 \\
\hline Total length bridges & $\mathrm{n} / \mathrm{a}$ \\
\hline Number of culverts & 33 \\
\hline Total length culverts & $\mathrm{n} / \mathrm{a}$ \\
\hline Road crossing & 12 \\
\hline Railroad overpass & 4 \\
\hline $\begin{array}{c}\text { Intersections overhead } \\
\text { electrical lines }\end{array}$ & 18 \\
\hline Deposit demolition & 1 \\
\hline Administrative units & $\begin{array}{c}\text { Dumbrava, Albești - Paleologu, Tomșani, } \\
\text { Colceag, Baba Ana, Mizil, Sahateni, } \\
\text { Breaza, Pietroasele, Ulmeni, Merei, Stâlpu, } \\
\text { Buzău, Vadu Pasii, Poșta Câlnău }\end{array}$ \\
\hline
\end{tabular}

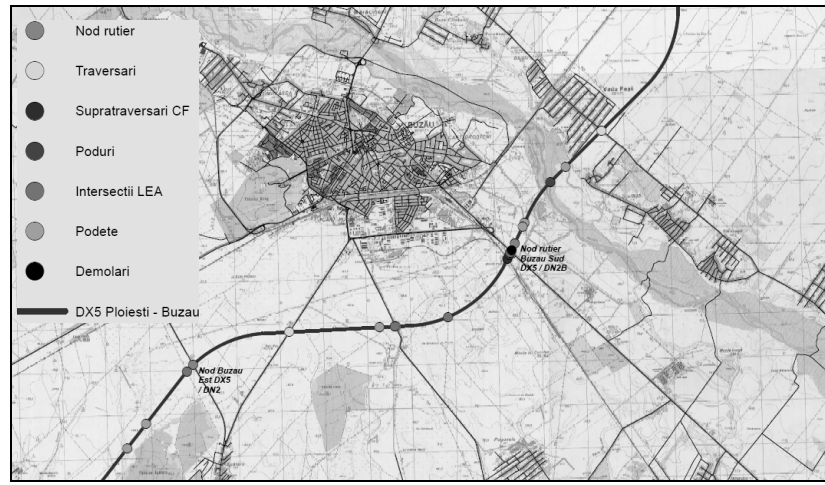

Fig. 1. The identification of the main general geomorphological processes that affect the TEN-T Core and Comprehensive network

The geomorphotechnique analysis aims to harmonize the relation between the geomorphological processes, the construction solutions and the transport infrastructure [2].

The geomorphological approach involves several stages:

- identifying areas along the existing or planned transport networks, which are affected or can be affected by the geomorphological processes;

- establishing the intensity and the maximum manifestation of the geomorphological processes; 
- determining the necessary protection work types in order to protect the transportation infrastructure;

- determining the manifestation area dimension and the solution adopted in correlation with the geomorphological processes intensity.

\section{THE RESULTS}

In this analysis we obtained the best location of the parameters such as: road junctions, bridges, culverts, road crossing, railroad overpass, railroad overpass, and intersections with areal electrical lines, deposit demolition, for the fast road Ploiești - Buzău. We consider that is necessary to use the same approach for the next sectors: Buzău - Focșani, Focşani - Bacău and Bacău Pașcani, for better and faster project implementation.

Generally a straight path is chosen only when using some smart solutions. In many cases we are used large curves succession for using the advantage that the relief provides. These dimensions determine a maximum design speed of $140 \mathrm{~km} / \mathrm{h}$.

From the of 65 km length of Ploiești - Buzău sector, we determined the lengths of the structures pesented in Table II.

TABLE II. THE PARAMETERS PROPOSED FOR PLOIEȘTI - BUZĂU SECTOR

\begin{tabular}{|c|c|c|c|}
\hline Id & $\begin{array}{c}\text { Code } \\
\text { emplacement }\end{array}$ & Characteristic & Validated \\
\hline & \multicolumn{3}{|c|}{ Road junctions } \\
\hline 1 & 1 & Speed road junction A3 / DX5 Dumbrava & Yes \\
\hline 1 & 11 & Cricov node DX5 / DN1D & Yes \\
\hline 1 & 28 & Mizil node DX5 / DJ102H & Yes \\
\hline 1 & 61 & Buzau Est node DX5 / DN2 & Yes \\
\hline 1 & 72 & Buzau Sud node DX5 / DN2B & Yes \\
\hline \multirow[t]{2}{*}{1} & 79 & Buzau Vest node DX5 / DJ220 & Yes \\
\hline & \multicolumn{3}{|c|}{ Overpass and undercrossings } \\
\hline 2 & 2 & DX5 crossing over DJ101F & Yes \\
\hline 2 & 15 & DX5 is crossed over by DJ102N & Yes \\
\hline 2 & 19 & DX5 is crossed over by DJ101E & Yes \\
\hline 2 & 23 & DX5 is crossed over by DJ102D & Yes \\
\hline 2 & 25 & DX5 is crossed over by DC77 & Yes \\
\hline 2 & 39 & DX5 is crossed over by DJ103R & Yes \\
\hline 2 & 46 & DX5 is crossed over by DJ203C & Yes \\
\hline 2 & 55 & DX5 is crossed over by DJ203G & Yes \\
\hline 2 & 62 & DX5 is crossed over by DN2B & Yes \\
\hline 2 & 65 & DX5 is crossed over by DJ203D & Yes \\
\hline 2 & 69 & DX5 is crossed over by DN2B & Yes \\
\hline \multirow[t]{2}{*}{2} & 77 & DX5 is crossed over by DJ203K & Yes \\
\hline & \multicolumn{3}{|c|}{ Railway overpass } \\
\hline 3 & 4 & $\begin{array}{l}\text { DX5 is crossing over the non-electrified } \\
\text { double railway Ploiesti - Urziceni, } 701 \\
\text { route, in operation }\end{array}$ & Yes \\
\hline 3 & 67 & $\begin{array}{l}\text { DX5 over crossing electrified double } \\
\text { railway Buzau - Faurei 702, in operation }\end{array}$ & Yes \\
\hline 3 & 68 & $\begin{array}{l}\text { DX5 crosses over the rail joint Buzau } \\
\text { Sud - Ram. Bobocu } 702 \text { / 500, in } \\
\text { operation }\end{array}$ & Yes \\
\hline \multirow[t]{2}{*}{3} & 78 & $\begin{array}{l}\text { DX5 ver crossing electrified double } \\
\text { railway Buzau - Focsani 500, in } \\
\text { operation } \\
\end{array}$ & Yes \\
\hline & \multicolumn{3}{|c|}{ Bridges over the network basin } \\
\hline 4 & 6 & Bridge over the river Vatmanu & Yes \\
\hline 4 & 10 & Bridge Cricovu Sarat & Yes \\
\hline 4 & 13 & bridgeValea Razboiului & Yes \\
\hline 4 & 36 & Bridge over the river Naianca & Yes \\
\hline 4 & 45 & Bridge over the river Sarata & Yes \\
\hline \multirow[t]{2}{*}{4} & 75 & Bridge over the river Buzau & Yes \\
\hline & \multicolumn{3}{|c|}{ Intersections with aerial electrical lines } \\
\hline 5 & 40 & $\begin{array}{c}\text { LEA } 20 \text { kw between Istrita de Jos and } \\
\text { Gageni }\end{array}$ & Yes \\
\hline
\end{tabular}

\begin{tabular}{|c|c|c|c|}
\hline 5 & 64 & LEA 20 kw between Buzau si Pogoanele & Yes \\
\hline 5 & 3 & $\begin{array}{c}\text { LEA } 20 \text { kw between Dumbrava and } \\
\text { Ciupelnita }\end{array}$ & Yes \\
\hline 5 & 5 & $\begin{array}{c}\text { LEA } 20 \text { kw between Dumbrava and } \\
\text { Trestienii de Jos }\end{array}$ & $\begin{array}{l}\text { To validate } \\
\text { in the field }\end{array}$ \\
\hline 5 & 7 & $\begin{array}{c}\text { LEA } 110 \text { kw between Brazi and } \\
\text { Bucuresti Sud }\end{array}$ & Yes \\
\hline 5 & 14 & LEA $20 \mathrm{kw}$ between Colceag and Perepa & Yes \\
\hline 5 & 20 & $\begin{array}{c}\text { LEA } 20 \text { kw between Baba Ana and } \\
\text { Fulga de Sus }\end{array}$ & Yes \\
\hline 5 & 24 & $\begin{array}{l}\text { LEA } 20 \text { kw between Baba Ana and } \\
\text { Gradistea }\end{array}$ & Yes \\
\hline 5 & 26 & $\begin{array}{c}\text { LEA } 20 \text { kw between Baba Ana and } \\
\text { Ciresanu }\end{array}$ & Yes \\
\hline 5 & 27 & $\begin{array}{l}\text { LEA } 20 \text { kw between Baba Ana and } \\
\text { Ciresanu }\end{array}$ & $\begin{array}{l}\text { To validate } \\
\text { in the field }\end{array}$ \\
\hline 5 & 33 & LEA 400 kw between Brazi and Stalpu & Yes \\
\hline 5 & 37 & LEA 20 kw Sahateni - Gageni & $\begin{array}{l}\text { To validate } \\
\text { in the field }\end{array}$ \\
\hline 5 & 41 & LEA 400 kw between Brazi and Stalpu & Yes \\
\hline 5 & 54 & $\begin{array}{c}\text { LEA } 110 \text { kw between Stalpu and } \\
\text { Pietrosu }\end{array}$ & Yes \\
\hline 5 & 56 & LEA $20 \mathrm{kw}$ between Stalpu and Pietrosu & Yes \\
\hline 5 & 60 & LEA 20 kw between Buzau and Spataru & Yes \\
\hline 5 & 66 & AE L $110 \mathrm{kw}$ & Yes \\
\hline \multirow[t]{2}{*}{5} & 70 & AE L $20 \mathrm{kw}$ & Yes \\
\hline & \multicolumn{3}{|c|}{ Culverts } \\
\hline 6 & 8 & Culvert over wet area, the torrent origin & Yes \\
\hline 6 & 9 & Torrent culvert Valea Mare & Yes \\
\hline 6 & 12 & $\begin{array}{c}\text { Torrent culvert tributary Valea } \\
\text { Razboiului vest }\end{array}$ & Yes \\
\hline 6 & 14 & $\begin{array}{c}\text { Torrent culvert tributary Valea } \\
\text { Razboiului est }\end{array}$ & Yes \\
\hline 6 & 16 & Culvert over Viroaga Ceptura & Yes \\
\hline 6 & 17 & Culvert over Paraul Balana & Yes \\
\hline 6 & 18 & Culvert over Valea Baba Sima & Yes \\
\hline 6 & 21 & Culvert over irrigation channel & Yes \\
\hline 6 & 22 & Culvert over Paraul Ghighiu & Yes \\
\hline 6 & 29 & $\begin{array}{l}\text { Culvert over irrigation channel and } \\
\text { agricultural road }\end{array}$ & Yes \\
\hline 6 & 30 & $\begin{array}{c}\text { Culvert over irrigation channel and } \\
\text { agricultural road }\end{array}$ & Yes \\
\hline 6 & 31 & $\begin{array}{l}\text { Culvert over irrigation channel and } \\
\text { agricultural road }\end{array}$ & Yes \\
\hline 6 & 32 & $\begin{array}{l}\text { Culvert over irrigation channel and } \\
\text { agricultural road }\end{array}$ & Yes \\
\hline 6 & 34 & $\begin{array}{l}\text { Culvert over irrigation channel and } \\
\text { agricultural road }\end{array}$ & Yes \\
\hline 6 & 35 & $\begin{array}{c}\text { Culvert over irrigation channel and } \\
\text { agricultural road }\end{array}$ & Yes \\
\hline 6 & 38 & $\begin{array}{c}\text { Culvert over irrigation channel and } \\
\text { agricultural road }\end{array}$ & Yes \\
\hline 6 & 42 & $\begin{array}{c}\text { Culvert over irrigation channel and } \\
\text { agricultural road }\end{array}$ & Yes \\
\hline 6 & 43 & $\begin{array}{c}\text { Culvert over irrigation channel and } \\
\text { agricultural road }\end{array}$ & Yes \\
\hline 6 & 44 & $\begin{array}{c}\text { Culvert over irrigation channel and } \\
\text { agricultural road }\end{array}$ & Yes \\
\hline 6 & 47 & $\begin{array}{l}\text { Culvert over irrigation channel and } \\
\text { agricultural road }\end{array}$ & Yes \\
\hline 6 & 48 & $\begin{array}{l}\text { Culvert over irrigation channel and } \\
\text { agricultural road }\end{array}$ & Yes \\
\hline 6 & 49 & $\begin{array}{l}\text { Culvert over irrigation channel and } \\
\text { agricultural road }\end{array}$ & Yes \\
\hline 6 & 50 & $\begin{array}{c}\text { Culvert over irrigation channel and } \\
\text { agricultural road }\end{array}$ & Yes \\
\hline 6 & 51 & Culvert over agricultural road & Yes \\
\hline 6 & 52 & $\begin{array}{c}\text { Culvert over irrigation channel and } \\
\text { agricultural road }\end{array}$ & Yes \\
\hline 6 & 53 & $\begin{array}{l}\text { Culvert over irrigation channel and } \\
\text { agricultural road }\end{array}$ & Yes \\
\hline 6 & 57 & $\begin{array}{c}\text { Culvert over irrigation channel and } \\
\text { agricultural road }\end{array}$ & Yes \\
\hline 6 & 58 & Culvert over Paraul Calmatui & Yes \\
\hline 6 & 59 & Culvert over Paraul Calmatui & Yes \\
\hline 6 & 63 & $\begin{array}{c}\text { Culvert over torrent Stramba Maneasca } \\
\text { Est }\end{array}$ & Yes \\
\hline 6 & 73 & $\begin{array}{c}\text { Culvert over irrigation channel and } \\
\text { agricultural road }\end{array}$ & Yes \\
\hline 6 & 74 & $\begin{array}{c}\text { Culvert over irrigation channel and } \\
\text { agricultural road }\end{array}$ & Yes \\
\hline 6 & 76 & Culvert over Buzau river arm & To valid \\
\hline
\end{tabular}




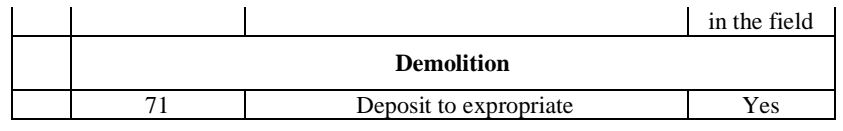

\section{CONCLUSIONS}

The GIS provided solutions were subsequently validated based on the performed work in the field. This analysis demonstrated that this type of study is a good point for infrastructure road project starting.

We consider therefore that the geomorphotechnique analysis is an important step from the major project implementation. The geomorphotechnique map can be considered a very useful tool for both designers and engineers.

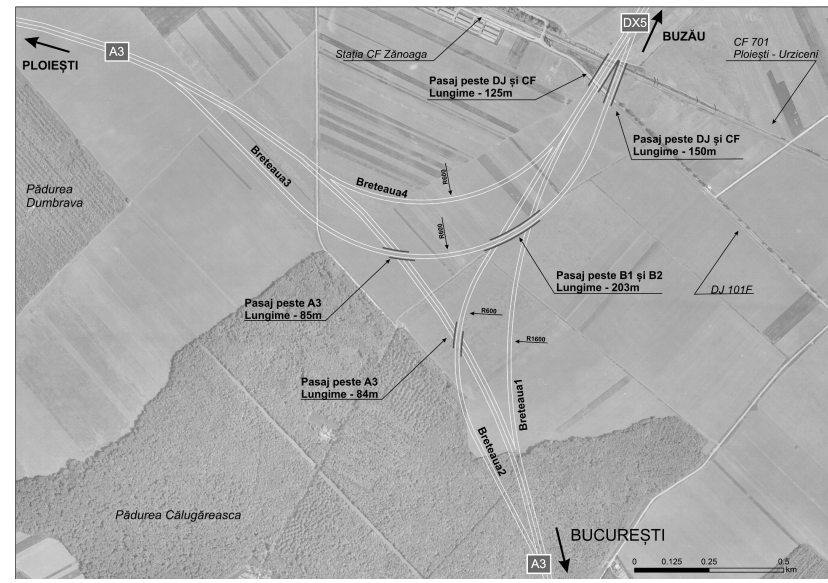

Fig. 2. The location node Dumbrava road speed $(\mathrm{km} .52+150 / 0+000)$ wide. $44^{\circ} 50^{\prime} 51.61$ "N, long. $26^{\circ} 12 ' 23.82 "$

\section{REFERENCES}

[1] R. Dobre, "Relaţia dinamica reliefului-infrastructura de transport", Editura Etnologică, București, 2016. (in Romanian)

[2] R. Dobre, "Pretabilitatea reliefului pentru căi de comunicații şi transporturi în Culoarul Prahovei (sectoarele montan şi subcarpatic)", Editura Universitară, Bucureşti, ISBN 978-606-591235-9, 245 p, 2011. (in Romanian) 


\title{
Early warning intelligent system for road transportation risks
}

\author{
Robert Dobre, Laurențiu Ilie, Ionuț Săvulescu, Mădălina Teodor \\ Geomorphology - Pedology - Geomatics Department \\ Faculty of Geography, University of Bucharest \\ Bucharest, Romania
}

\begin{abstract}
This project is based on an action that is agreed with the Innovation and Networks Executive Agency (INEA) and is based on Intelligent Transport Systems. Romanian TEN-T network is seriously affected by natural risks such as landslides, torrential erosion, rock falls, avalanches, floods and heavy snow. These natural hazards lead to numerous road accidents which cause important casualties and material losses every year.
\end{abstract}

The overall objective of the action is to improve traffic safety and reduce congestion of the Romanian road Core and Comprehensive Network by putting in place a compatible, accessible and interoperable intelligent transportation system (ITS) that will provide traffic and travel information services in all European languages via web.

Keywords - intelligent transport; roads; geomorphological processes

\section{INTRODUCTION}

This project is based on an action that is agreed with the Innovation and Networks Executive Agency (INEA) Department C - Connecting Europe Facility (CEF). The action aim is to contribute to the implementation of the comprehensive network, horizontal priority: Telematic applications systems for road (ITS), and on the core network Corridors: Orient/East-Med, Rhine-Danube.

\section{LOCATION OF THE ACTION}

The project is representative for the country of Romania and is based on the TEN-T Core network corridors

\section{SCOPE AND OBJECTIVES}

The ITS (Intelligent Transport Systems) are being applied to facilitate mobility, make better use of existing infrastructure, improve safety and help mitigating negative environmental impacts. Deployment of ITS is also motivated by the increased difficulty of expanding transportation capacity through conventional infrastructure building.

Romanian TEN-T network is seriously affected by natural risks such as landslides [1], torrential erosion [2], rock falls [3], avalanches, floods and heavy snow [4]. These natural hazards lead to numerous road accidents which cause important casualties and material losses every year [5].

The overall objective of the action is to improve traffic safety and reduce congestion of the Romanian road Core and Comprehensive Network by putting in place a compatible, accessible and interoperable intelligent transportation system (ITS) that will provide traffic and travel information services in all European languages via web.

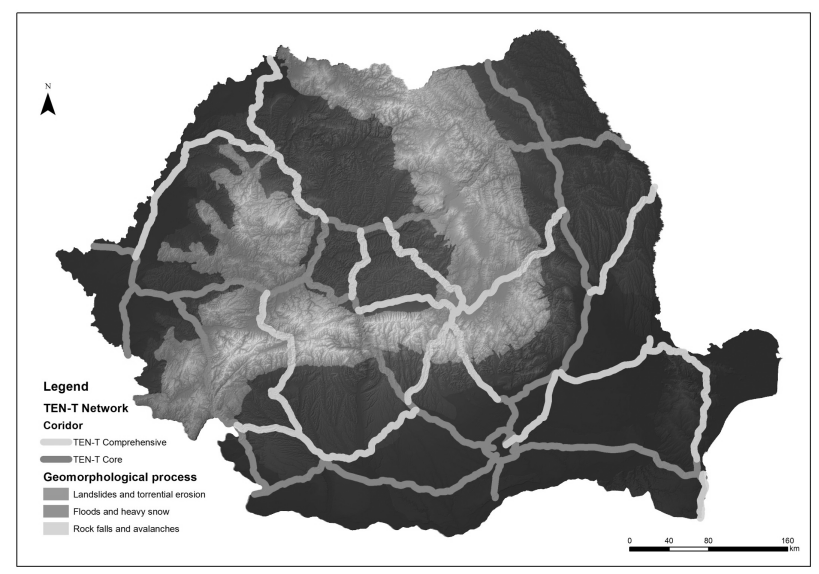

Fig. 1. The identification of the main general geomorphological processes that affect the TEN-T Core and Comprehensive network

To deliver on the overall objective of the Action, there are three specific objectives, which will be met by carrying out eleven activities within the Action:

1. Sizing risks that can affect road transportation;

2. Identification of the data sources;

3. Elaboration of the tender documentation and public tender process;

4. Back-end platform and applications architecture design;

5. Development of the back-end platform;

6. Developing the web application;

7. Developing the mobile applications;

8. Collecting user's feedback;

9. Improving applications on the basis of the collected feed-back;

10. Validation and testing;

11. Information and Advertising Campaign; 


\section{Project Management.}

The first specific objective is to contribute to the accessibility of interoperable accurate road and traffic saferelated data across the EU through the set-up of a national access point. This objective will be met by identifying and characterising the list of risks that can affect road transportation [1], through the identification of the corresponding data sources in line with and by making data available in a standardised format across Europe and in neighbouring countries through a national access point that will consist on an interoperable application module designed, set-up and made available via web and mobile [4].

The second specific objective is to contribute to reducing the number of accidents, transport time and fuel consumption in the Romanian TEN-T network by providing real-time safety-related traffic information services to road users via well-functioning web and mobile applications. These services will cover information on a wide range of risks and will be easily accessed by the general public using various devices, including smartphones, tablets and laptops. This objective will be met through the design and the implementation of a cloudbased back-end platform, a cloud-based web application and some mobile applications for the most popular Operating Systems which will provide real-time safetyrelated traffic information services to road users. A testing and validation process will be carried out so as to ensure that the web and mobile applications have been designed in compliance with the identified data sources and risks and implemented in line with the applications design. Moreover, the web and mobile applications will be finetuned on the basis of the user's feedback collected through dedicated forms as well as from the comments posted in the application stores. A software development firm will be contracted via a public procurement procedure for the design, the development and fine-tune of the back-end platform, the web and the mobile applications.

The third specific objective is to inform the road users, ITS service providers and road users about the results of this Action. This objective will be met by designing and implementing an Information and Advertising Campaign.

\section{USING THE RESULTS} study.

The results of this project can be determined by case

On December 1st 2015, on the DN7 national road (Olt Valley, Core Network) it was a minor accident (without casualties). The accident led to block traffic in both directions. The accident was caused by falling rocks which broke away from the slopes $\left(2200 \mathrm{~m}^{3}\right)$. In order to increase the road safety, the National Company of Motorways and National Roads in Romania (CNAIR). Thus, several hundreds of vehicles including dozens of cargo transport truck were blocked on the Olt Valley. After several hours of waiting and an assessment of CNADNR specialists, it was decided to redirect the traffic on an alternative route.

The case study was developed for a charged truck on the Nădlac (Romania - Hungary border) - port of Constanta on the Black Sea route. The analyzed vehicle has 40 tones mass, 5 axes, emmissions class Euro 5 and has green pollution permits.
Three scenarios were simulated:

A scenario - Transport by truck to a normal situation

$B$ scenario - the truck transport without the benefit of accident alert along its route (Scenario without the project) - present situation

C scenario - the truck transport with the benefit of alert along its route (project scenario) - results from CEF projects. Has been completed, the paper is ready for the template. Duplicate the template file by using the Save As command, and use the naming convention prescribed by your conference for the name of your paper. In this newly created file, highlight all of the contents and import your prepared text file. You are now ready to style your paper; use the scroll down window on the left of the MS Word Formatting toolbar.

\section{A scenario}

In a normal situation (without route incident), the truck route linking Nadlac to Constanta it is $834 \mathrm{~km}$ : Nădlac Arad - Timișoara - Lugoj - Deva - Sibiu - Rm. Vâlcea Pitești - București - Constanța.

TABLE I. THE PARAMETERS FOR A SCENARIO

\begin{tabular}{|c|c|c|c|c|c|c|c|c|}
\hline $\begin{array}{c}\text { Route } \\
\text { length } \\
(\mathrm{km})\end{array}$ & $\begin{array}{c}\text { Journey } \\
\text { time }\end{array}$ & $\begin{array}{c}\text { Fuel } \\
\text { consuption } \\
\text { (liters) }\end{array}$ & $\begin{array}{c}\text { Average } \\
\text { consumpt } \\
\text { ion } \\
\text { (liters) }\end{array}$ & $\begin{array}{c}\text { Total } \\
\text { Fuel } \\
\text { Cost } \\
(\text { euro })\end{array}$ & $\begin{array}{c}\text { CO2 } \\
(\mathrm{kg})\end{array}$ & $\begin{array}{c}\text { NOx } \\
(\mathrm{g})\end{array}$ & $\begin{array}{c}\mathrm{N2O} \\
(\mathrm{g})\end{array}$ & $\begin{array}{c}\mathrm{CH} 4 \\
(\mathrm{~g})\end{array}$ \\
\hline 834 & $15 \mathrm{~h} 38$ & 321 & 38,5 & 319,6 & 849 & 3352 & 49 & 1,92 \\
\hline
\end{tabular}

\section{B scenario}

In the event that an incident occurs on the truck route (Nadlac to Constanta Port), the route is rerouting after arriving at the incident and analyzing the situation. In this scenario, the route is: Nădlac - Arad - Timișoara Lugoj - Deva - Sibiu - Brezoi - incident location - Brezoi - Sibiu - Brașov - Predeal - Câmpina - Ploiești București - Cernavodă - Constanța. The route length has 979 km, 145 km 14 more than the A scenario.

TABLE II. THE PARAMETERS FOR B SCENARIO

\begin{tabular}{|c|c|c|c|c|c|c|c|c|}
\hline $\begin{array}{c}\text { Route } \\
\text { length } \\
(\mathrm{km})\end{array}$ & $\begin{array}{c}\text { Journey } \\
\text { time }\end{array}$ & $\begin{array}{c}\text { Fuel } \\
\text { consuption } \\
\text { (liters) }\end{array}$ & $\begin{array}{c}\text { Average } \\
\text { consumpt } \\
\text { ion } \\
\text { (liters) }\end{array}$ & $\begin{array}{c}\text { Total } \\
\text { Fuel } \\
\text { Cost } \\
(\text { euro })\end{array}$ & $\begin{array}{c}\text { CO2 } \\
(\mathrm{kg})\end{array}$ & $\begin{array}{c}\mathrm{NOx} \\
(\mathrm{g})\end{array}$ & $\begin{array}{c}\mathrm{N2O} \\
(\mathrm{g})\end{array}$ & $\begin{array}{c}\mathrm{CH} \\
(\mathrm{g})\end{array}$ \\
\hline 979 & $19 \mathrm{~h} 09$ & 387,7 & 39,6 & 386 & 1023 & 4050,6 & 57,6 & 2,27 \\
\hline
\end{tabular}

\section{C scenario}

In the chase that the truck driver is alerted by the application, the route is redirected before arriving at accident. Thus, the route will be as follows: Nădlac - Arad - Timișoara - Lugoj - Deva - Sibiu - Brașov - Predeal Câmpina - Ploiești - București - Cernavodă - Constanța. The route has $870 \mathrm{~km}$. In this case, it will be $109 \mathrm{~km}$ less then B Scenario and just $36 \mathrm{~km}$ more than A Scenario.

\section{CONCLUSIONS}

The project may represent a first step in a larger project that will aim to implement across borders in cooperation with the TEN-T networks roads, in neighboring countries (Hungary, Bulgaria and Serbia). 


\section{REFERENCES}

TABLE III. THE PARAMETERS FOR CSCENARIO

\begin{tabular}{|c|c|c|c|c|c|c|c|c|}
\hline $\begin{array}{c}\text { Route } \\
\text { length } \\
(\mathrm{km})\end{array}$ & 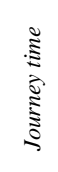 & 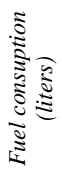 & $\begin{array}{c}\text { Average } \\
\text { consumpt } \\
\text { ion } \\
\text { (liters) }\end{array}$ & $\begin{array}{l}\text { Total } \\
\text { Fuel } \\
\text { Cost } \\
\text { (euro) }\end{array}$ & $\begin{array}{l}\mathrm{CO} 2 \\
(\mathrm{~kg})\end{array}$ & $\begin{array}{c}N O x \\
(g)\end{array}$ & $\begin{array}{c}N 2 O \\
(g)\end{array}$ & $\begin{array}{c}\mathrm{CH} 4 \\
(\mathrm{~g})\end{array}$ \\
\hline 870 & $\begin{array}{l}16 \mathrm{~h} \\
28\end{array}$ & 335 & 38,5 & 333,5 & 884 & 3522,7 & 51 & 2 \\
\hline
\end{tabular}

TABLE IV. DIFERENCE BETWEEN SCENARIO B AND SCENARIO C (PERCENT \%)

\begin{tabular}{|c|c|c|c|c|c|c|c|c|}
\hline $\begin{array}{c}\text { Route } \\
\text { length } \\
(\mathrm{km}\end{array}$ & $\begin{array}{l}\text { है } \\
\text { ఫे } \\
\stackrel{\Xi}{\Xi}\end{array}$ & 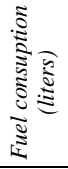 & $\begin{array}{c}\text { Average } \\
\text { consumpt } \\
\text { ion } \\
\text { (liters) }\end{array}$ & $\begin{array}{l}\text { Total } \\
\text { Fuel } \\
\text { Cost } \\
\text { (euro) }\end{array}$ & $\begin{array}{c}\mathrm{CO} 2 \\
(\mathrm{~kg})\end{array}$ & $\begin{array}{c}N O x \\
(g)\end{array}$ & $\begin{array}{c}N 2 O \\
(g)\end{array}$ & $\begin{array}{c}\mathrm{CH} 4 \\
(\mathrm{~g})\end{array}$ \\
\hline $\begin{array}{ll}11,1 \\
\end{array}$ & 14 & 13,6 & 2,8 & 13,6 & 13,6 & 13,0 & 11,5 & 11,9 \\
\hline
\end{tabular}

The results of the project has major environmental benefits in terms of air pollution, the risk of accidents, as well as benefits related to the transport costs.

In this first phase of implementation of the projected costs are higher because it will create a structure and database, the second phase having lower costs as it would target only the update of the created database

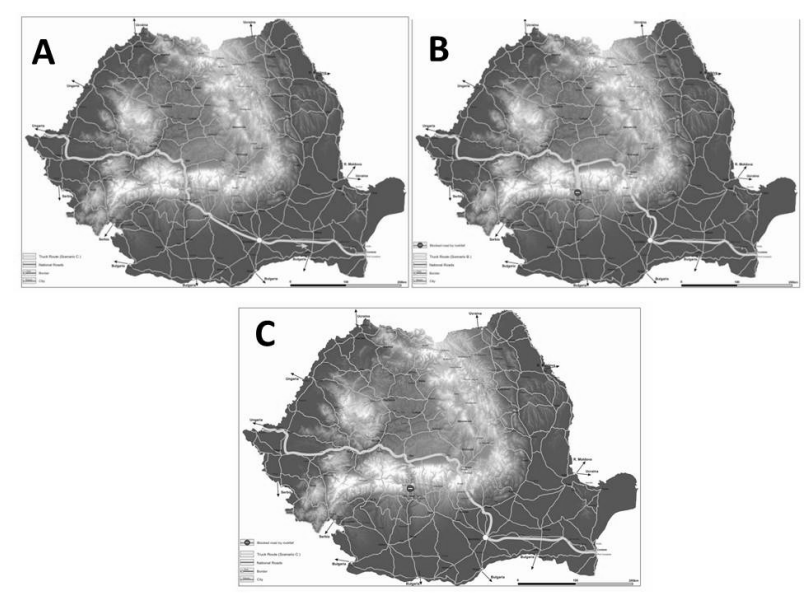

Fig. 2. Auto rote in a normal situation, truck transport without the benefit of accident alert along its route (Scenario without the project) and truck transport with the benefit of alert along its route (project scenario)

\section{ACKNOWLEDGMENT}

This project was financial supported by the European Commission - Innovation and Networks Executive Agency (INEA) Department C - Connecting Europe Facility (CEF), 2015-RO-TM-0435-W grant.
[1] R. Dobre, Relatia dinamica reliefului-infrastructura de transport, Editura Etnologică, București, 2016. (in Romanian)

[2] T. Mădălina, "Geomorphological processes susceptibility assessment using GIS analysis in Ilwis software. Case study: Ialomiţa Upper Valley (Romania)", Revista de Geomorfologie, vol. 15, pp. 109-118, 2013.

[3] R. Dobre, Pretabilitatea reliefului pentru căi de comunicaţii şi transporturi în Culoarul Prahovei (sectoarele montan şi subcarpatic), Editura Universitară, Bucureşti, ISBN 978-606-591235-9, 245 p., 2011. (in Romanian)

[4] F. Grecu, Hazarde şi riscuri naturale, Ed. a IV-a, Editura Universitară, Bucureşti, 2009. (in Romanian)

[5] R. Dobre, B. Mihai, and I. Săvulescu, "The Geomorphotechnical Map: a highly detailed geomorphic map for railroad infrastructure. A case study for the Prahova River Defile (Curvature Carpathians, Romania)”, Journal of Maps, v2011, pp. 126-137. 10.4113/jom.2011.1155, 2011 


\title{
The role of human activities in streambank
}

\section{stability: Lower Sakarya River (NW Turkey)}

\author{
Umit Duru \\ Department of Geography \\ Sakarya University \\ Sakarya, Turkey \\ umitduru@sakarya.edu.tr
}

\begin{abstract}
The main objective of this study is to determine historic and current human impacts on streambank stability in Lower Sakarya River. Remote sensing and Geographical Information System techniques with conjunction fieldworks were performed in order to identify the impact of human alteration on streambank stability in the riverine environment, $8.1 \mathrm{~km}$ along Sakarya River, the western portion of Sakarya province. Historical streambank movements were analyzed from Landsat satellite images in 1995, 2002 and 2016, respectively. As results, a significant land use changes have been observed along the river's floodplain. Recently, change in land use type from agricultural to urban usage has been observed in the region. The stream channel also became more stable and straight because man-made modifications including a hydropower dam constructed in $\mathbf{2 0 1 0}$ primarily reduced flood frequency, water velocity, stream power, shear stress on sediment particles deposited along the streambank. On the other hand, instream mining activities in the region disturb active streambanks, which raise a concern about instability of streambank and potential damage to infrastructures. Such studies are extremely important for understanding basic mechanisms of streambank evolution for further river restoration practices.
\end{abstract}

Keywords - streambank stability; anthropogenic effects; GIS; Sakarya River

\section{INTRODUCTION}

Streambank stability is here defined as the resistance of channel bed to natural and anthropogenic changes, and its resilience through years. Besides natural processes, the rate of streambank stability can be greatly altered by human modifications (channel modifications, reservoir constructions, land use/cover changes etc). Although such activities are crucial for development, they may have adverse effects in riverine environment. Human modified the environment to suite their demand and how people adapt to prevail environment is explained by Human environment interactions by the National Council for Geographic Education and the Association of American Geographers. Instream modifications usually lead to a noticeable decrease in bank erosion; channel migration so far as native species conserved in a riparian zone. Human induced changes in a stream channel may culminate in numerous environmental and socioeconomic consequences including loss of riparian zones and damage in infrastructures. For example, concrete armoring channels demolish the species in riparian areas, and removing riparian vegetation can also alter the morphology and natural dynamics of rivers $[1,2]$.

The rivers response anthropogenic activities with several channel parameters for instance incisions, narrowing, migration etc. [3]. These parameters are mainly resulted from disturbing the equilibrium of river dynamics and accelerate the rate of bank erosion. Human induced river bank erosion may become a natural disaster when people destroy natural species and settled within riparian zone, at least $100 \mathrm{~m}$ wide each side. [4] reported that narrower buffers provide habitat benefits for many species; however, protecting various riparian communities requires at least $100 \mathrm{~m}$ buffer zone. Numerous researches have made significant contribution on alteration of human activities in stream channels such as instream mining operations [5], dam or bridge contractions [6, 7]; channel restorations [8]; and land use/cover changes [9]. Yamani et al., [9] reported that anthropogenic activities have more superior impacts on river dynamics than natural events.

Human activities can cause drastic changes to the fluvial geomorphic stability of stream channel as a geological agent, respect to leaving some fingerprints on the earth surfaces. In order to examine how human alterations historically impact stream channel, Remote Sensing (RS) and Geographical Information System (GIS) techniques have become widely used in the last decades because remotely sensed images provide historical snapshot of stream channel displacements utilizing digital imageries. A reliable monitoring of temporal water resource dynamics using an integrated approach of RS and GIS enable to track historical changes among time intervals [10]. The main objective of the study is to assess how streambanks response land use changes in the floodplain of Sakarya River through years, and discuss potential factors controlling streambank stability in the last decades. Such studies are becoming extremely important for better understanding of current settings, the future and past stream channel evolution, which can be used further stream restoration practices. 


\section{STUDY AREA}

The Sakarya River is located in the northwest Anatolian region of Turkey, a length of approximately 820 km (Figure 1). The basin area of Sakarya River is nearly $54.000 \mathrm{~km}^{2}$, which is the third largest basin in Turkey. The study area, a length of $8.1 \mathrm{~km}$ and $200 \mathrm{~m}$ wide each side, is situated between D-100 highway to Historical Sakarya Bridge, west of the Sakarya province. The mean annual precipitation in the region is $775 \mathrm{~mm}$, the most of the precipitation falls during winter (32.6\%); precipitation rate seen in the summer $(19.7 \%)$. The region experiences semihumid characteristics.
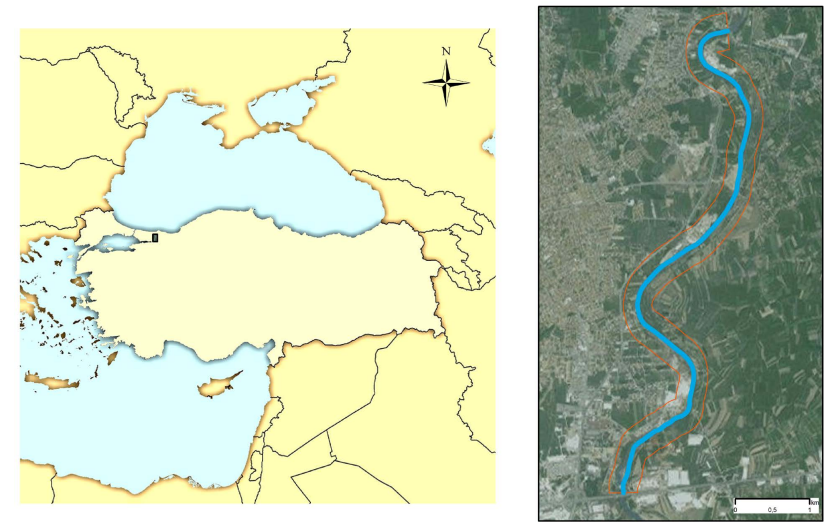

Fig. 1. The location map of study area.

The study area lies on alluvial deposits formed late Pliocene - Quaternary with gentle slopes. The mean annual discharge of $250 \mathrm{~m}^{3} / \mathrm{s}$ is observed at Botbasi gaging station (1243), which the closest gages recording stream flow. In the region, 3 ongoing instream mining operations, 2 out of order mining operations, 1 dam construction and 2 bridges leave significant fingerprints riverine environment. Moreover, an ongoing project respecting river restoration (e.g. concrete armoring of streambank, diversions of river) was recently started in the region. The western portions of the Sakarya River have a higher population density and are mainly characterized by alluvial plains. In the regions with higher population density, people settled in riparian zone.

\section{MATERIALS AND METHODS}

Various datasets were used to observe streambank stability in the region. The main input dataset utilized to monitor historical streambank changes are Landsat 1-5 Multispectral Scanner (MSS), Landsat-7 Enhanced Thematic Mapper Plus (ETM+) and Aster GDEM images obtained from United States Geological Surveys (USGS), Earth Explorer website (http://www.earthexplorer.usgs.gov) for a period from 1995 to 2016. All these images in Table 1 provide historical land use changes along urbanized portion of Sakarya River. Water discharge data from 1960 - 2002 at Botbasi gaging station (1243) was collected from State Hydraulic Works of Turkey (DSI). In addition two field works in 7 January 2017 and 14 March 2017 were conducted to collect data and relevant photographs of the Sakarya River sites where the anthropogenic activities are more pronounced.

Aster GDEM in $30 \mathrm{~m}$ resolution was used to delineate the $200 \mathrm{~m}$ buffer zone along the river. Then the Landsat images were utilized to extract land use maps. The discrete streambank lines were delineated from the multi-temporal images in ERDAS 9.2 software, and then all input data were transported as new shape files into ArcGIS 10.1 software. The comparison of the land use changes were analyzed from three different images in the three phases 1995 - 2002 (7 years), 2002 - 2016 (14 years), and 1995 2016 (21 years)

TABLE I. RESOLUTION OF SATELLITE IMAGES UTILIZED IN THE RESEARCH

\begin{tabular}{ccc}
\hline $\begin{array}{c}\text { Acquisition } \\
\text { date }\end{array}$ & Satellite/sensor & $\begin{array}{c}\text { Resolution } \\
\text { Spactral } \\
(\mathrm{m})\end{array}$ \\
\hline 9/July/1995 & Landsat MSS & 30 \\
10/May/2002 & Landsat MSS & 30 \\
15/July/2016 & Landsat ETM+ & 30 \\
04/June/2011 & Aster GDEM & 30 \\
\hline
\end{tabular}

Supervised classification method was considered an appropriate method for streambank detection, so measure the changes in land use and its effects on streambank stability were assessed in the last 21 years. Field work was carried out to observe human impact on Sakarya River. Along the riparian zone of the studied stream, dam construction, instream mining activities, bank rehabilitation works observed during the field work. The flow characteristics are also analyzed by some basic statistical techniques in MS Excel.

\section{RESULTS AND DisCUSSIONS}

The Sakarya River changed its bank based upon bank erosion, deposition caused by changes in flow characteristics, flood event, and land use change in the last two decades. Based on the field work observations, the eastern course of the bank has been eroded more especially at the sites surrounded by finer grain size. Cohesionless sand formation is the most dominant in the streambanks, so streambank erosion occurs with lower stream discharge due to lower bed shear stress for sediment transport. During the field work, boarder of perennial shrubs and trees were examined to define active channel boundary and historical channel migrations because vegetation cannot be excluded in the context of displacement in a streambank.

Adasu hydroelectric power station (HES) was constructed in the upstream of the reach in the year of 2010. The power station not only caused a reduction of channel flow, but more importantly flow regimes. The power dam also reduces stream velocity caused decreased in stream power, and the river is transport limited after its operation. After the Adasu HES operation more steady stream characters were observed due to primarily reduced flood frequency, water velocity, stream power, shear stress on sediment particles deposition along the streambank. Fluvial processes cannot be developed at low discharge of water. Despite variation in channel characteristics may occur, the implementation of a dam does not always causes geomorphic changes [3].

İnstream sand extraction operations on point bars along the stream channel have also loosened the stream bank correspondingly altering channel morphology. Sand extractions in the region have a direct impact on changing 
streambank properties such as removing sands from point bars alters streambank geometry in the region. Additionally bridge contractions caused local scouring on the stream bed. Bridge peers reduce velocity of water correspondingly stream power for sediment transport. Recently two arches of the historic bridge were filled with sediment at the downstream course of the study area. From 1995 to 2016, the width of the stream at the Historic Sakarya Bridge has reduced $\sim 30 \mathrm{~m}$, so the stream flows through the bridge using one arch.

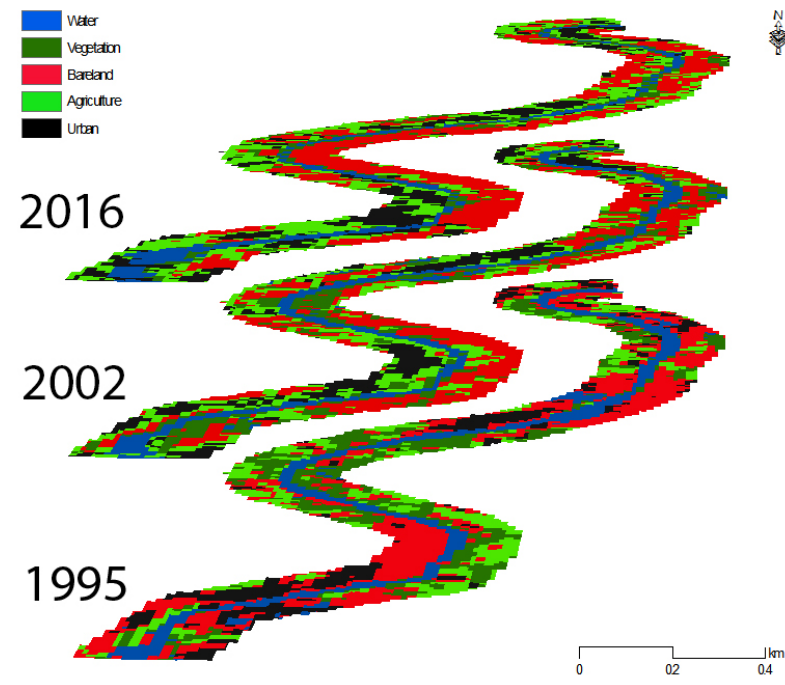

Fig. 2. Land use change along Sakarya River between 1995 and 2016

In the last three decades due to extensive changes in land use along the river, stream bank erosion rate has been increased. Population growth in the research area is significant in the past 3 decades, resulting expanding industrial as well as other anthropogenic activities around the stream channel. Change in land use type from agriculture to industrial usage has disturbed nature of channel dynamics. From satellite images, anthropogenic activities in the buffered zone has been increased as a result of construction infrastructures, settlements and industrial operations, so the displacement of streambanks varied from 0.29 to 0.18 in 1995 and 2016, respectively.

\section{CONCLUSIONS}

In conclusion, the results demonstrate that an integrated approach of RS and GIS to monitor anthropogenic impact by overlaying different land use maps can be a reasonable tool for streambank stability. Human induced hydrological changes in the channel such as dam construction and sand mining have a significant effect on changing streambank stability through years. Most noticeable human activities are dam construction and instream mining operations in this region. It should be noted here that the stream showing more steady stream characteristics especially after the HES construction. Also sand extraction in active channel has a significant impact on streambank mobility. Change in land use type from agriculture to industrial usage has been observed in the region. Such studies need to be supported and taken into consideration before river restorations because better understanding of how stream response to land use changes through years especially for a river flowing through densely populated areas is a significant task for a feasible river restoration practices.

\section{REFERENCES}

[1] G. M. Kondolf, "Hungry Water: Effects of Dams and Gravel Mining on River Channels Profile”, Environmental Management, vol. 21, no. 4, pp. 533-551, 1997.

[2] R. Rosso, M. C. Rulli, and D. Bocchiola, "Transient catchments hydrology after wildfires in a Mediterranean watershed: Runoff, sediment and woody debris”, Hydrol. Earth System Sci., vol. 11, no. 1, pp. 125- 140, 2007.

[3] D. Knighton, Fluvial Forms \& Processes: A New Perspective. Arnold, New York, 383 p., 1998.

[4] S. Wenger, A review of the scientific literature on riparian buffer width, extent and vegetation. Athens. GA: Office of Public Service and Outreach, Institute of Ecology, University of Georgia, 59 p., 1999.

[5] S. Ashraf, H. Afshari, and A.G. Ebadi, “Application of GIS for determination of groundwater quality suitable in crops influenced by irrigation water in the Damghan region of Iran”, Int. J. Phy. Sci., 6, no. 4, pp. 843-854, 2011.

[6] B. Gopal, "River conservation in the Indian sub-continent" in P.J. Boon, B.R. Davies and G.E. Petts, (Eds.), Global Perspectives on River Conservation. Science, Policy and Practice. Wiley, Chichester, 2000, pp. 233-261.

[7] M. Islam, Fakrul, Higano and Yoshiro, "Attainment of Economic Benefit through Optimal Sharing of International River Water: A Case Study of the Teesta River”, Indian Journal of Regional Science, vol. 34(2), pp. 1-10, 2002.

[8] N.J. Schofield, K.J. Collier, J. Quinn, F. Sheldon, F., and M.C. Thoms, "River conservation in Australia and New Zealand", in P.J. Boon, B.R. Davies and G.E. Petts, (Eds.), Global Perspectives on River Conservation. Science, Policy and Practice. Wiley, Chichester, 2000.

[9] M. Yamani, A. Goorabi, and J. Dowlati, "The Effect of Human Activities on River Bank Stability (Case Study)”, American Journal of Environmental Sciences, vol. 7, no. 3, pp. 244-247, 2011.

[10] J.R. Wallick, S.T. Lancaster, and J.P. Bolte "Determination of bank erodibility for natural and anthropogenic bank materials using a model of lateral migration and observed erosion along the Willamette River, Oregon USA”, River Research and Applications, vol. 22, no. 6, pp. 631-649, 2006. 


\section{The glacial buzzsaw and its limitations: mountain glaciation in British Columbia and in Britain}

\author{
Department of Geography \\ Durham University \\ Durham, UK \\ i.s.evans@durham.ac.uk
}

Ian Evans

\author{
Department of Geography \\ Faculty of Geography and History \\ Ştefan cel Mare University of Suceava \\ Suceava, Romania
}

\begin{abstract}
Erosion by warm-based glaciers is highly effective and has produced distinctive mountain landscapes. Downward erosion dominates, but headward erosion by recession of cirque headwalls is sufficient to displace drainage divides and lower summits on cirque crests. This 'glacial buzzsaw', however, is not universal: it does not apply in the many areas where low-gradient surfaces survive above cirques. It applies patchily in British Columbia, Britain and Romania.
\end{abstract}

Keywords—glacial buzzsaw; mountain glaciation; Bristish Columbia; Britain

There is now general agreement that glacial erosion can be faster than fluvial erosion, so long as ice is 'warm' and wet-based. In fact, glacial erosion rates increase with the amount of basal water [1] and with the rate of basal sliding: hence in Patagonia there is a maximum at $44^{\circ} \mathrm{S}$, where precipitation was greatest during the Last Glacial Maximum [2]. In a simple glacier, ice discharge and rates of basal sliding are greatest at the Equilibrium Line (E.L.). But in a large valley glacier system, tributaries converge to give greater discharges further down the trunk glacier: together with the increasing amount of basal water, this gives greater erosion downstream, where major troughs and rock basins are eroded. Considerable headward erosion is observed also at glacier sources, often on one side of a mountain range. This requires not just glacial abrasion, but also glacial quarrying and/or headwall collapse by rock mass failure. The balance between headward and downward glacial erosion seems to have varied at different stages of Quaternary glacial history [3].

The buzzsaw hypothesis asserts that rapid glacial erosion around the E.L. Altitude (ELA) tends to truncate mountain ranges and control the altitudes that summits can reach [4]. This implies that summits are on the edge of cirques and in course of being lowered as cirques develop. This is most clearly the case where sharp ridges delimit contiguous, intersecting cirques, as for example in the
Washington Cascades and the Southern Alps of New Zealand. It can apply also where contiguous cirques on one side of a ridge are extending at the expense of the opposite slope. It cannot apply where gentle summit slopes survive above the cirques, as in the Godeanu and Parîng Mountains [5]. As such gentle summits rise little above cirque headwalls, the general relation between summit altitudes and cirque floor altitudes [6] applies here as well as where ridges are sharp: thus it does not provide support for the buzzsaw hypothesis [7]. Support may be provided, however, by geomorphological mapping and detailed hypsometric analysis [8].

The southern Coast Mountains of British Columbia are deeply dissected by glacial erosion, both by ice sheets and local glaciers. Ridges are sharp, and mainly with intersecting cirques, as in the Bendor Range and farther west. They have clearly been lowered by headward cirque erosion, yet the evidence for a glacial buzzsaw is weaker than to the south in the Washington Cascades. Cirque floors follow the trend of ELA, which rises by $1000 \mathrm{~m}$ from the coast to the dry interior, but summit maxima do not. Thus as you go west or southwestward into the mountains, cirque glaciers are replaced by valley glaciers and eventually icefields as mountains rise higher above ELA (Fig.1). This implies that uplift has been rapid enough to take these mountains through the zone of most effective erosion. That is more evidently the case with the largest icefields of middle latitudes: Patagonia, the Karakoram and the St. Elias of Alaska, which are areas of very rapid glacial erosion. It is likely that rapid Quaternary uplift in these three areas carried mountains quickly through the zone of rapid glacial erosion, into that of cold ice frozen to its bed. This produced 'Teflon peaks', rapidly uplifted into the zone of cold, non-erosive ice, while ice streams eroded deeply in the valleys between. 


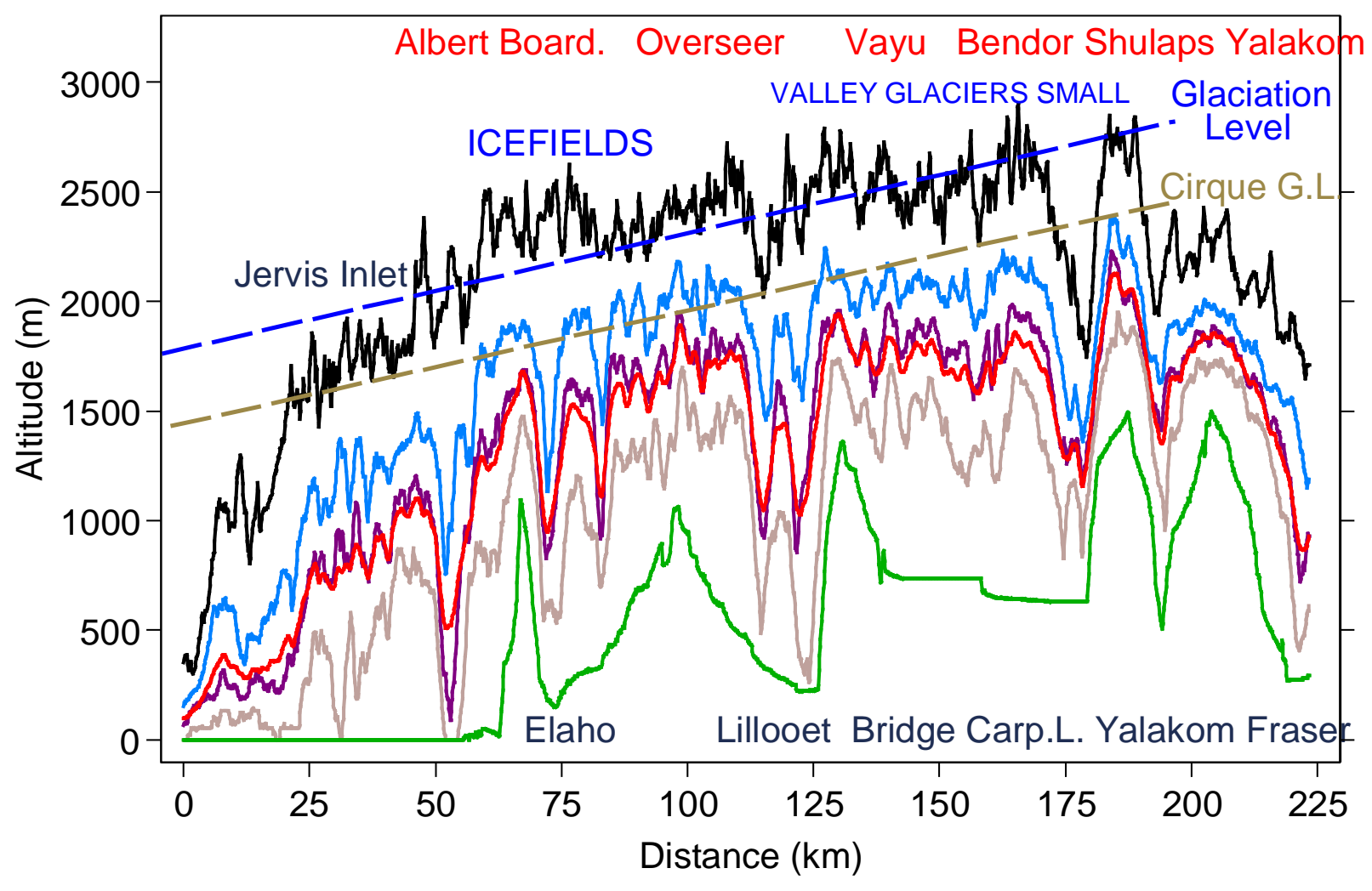

$\longrightarrow \max \longrightarrow$ p75 median- mean $\longrightarrow$ p25 $-\min$

Fig. 1. Swath profile across southern Coast Mountains, B.C.: $50 \mathrm{~km}$ bands every $100 \mathrm{~m}$. Mountain names in red, valleys in navy blue. Hypsometry from P. Bandura. (G.L. = Glaciation level, generally 200-300 m above ELA. Carp. L. = Carpenter Lake.).

Glaciation on the landward side of the Coast Mountains is strongly asymmetric in that glaciers formed and eroded cirques only on the shaded or leeward side of a mountain range.

Headward extension of adjacent cirques on a ridge leads to displacement of the divide, sometimes by $2 \mathrm{~km}$ or more [9], lowering ridge and summit altitudes in accordance with the buzzsaw hypothesis. Such forms of local glaciation have survived immersion in the Cordilleran Ice sheet, which overwhelmed almost all the Coast Mountains at the glacial maximum and created throughtroughs. Headward erosion by a few $\mathrm{km}$ is important in a number of other areas where glaciation was asymmetric (Table I). This considerable headwall retreat (cirque lengthening) supports the glacial 'buzzsaw', as summits are on cirque crests and are clearly being lowered.

In Britain, glaciation was asymmetric with a general northeastward tendency in cirque aspect reflecting increased glacier balance on both poleward and leeward slopes. A recent study mapped the distribution of cirques throughout Britain and Ireland [10]. It finds 1139 in Scotland, 637 in Ireland, 260 in Wales and 172 in England. As in British Columbia, cirques survived more extensive ice sheet glaciation at glacial maxima: only a few, as in the central fells of the English Lake District, show considerable modification by overriding ice. The 2208 cirques average $774 \mathrm{~m}$ long, $786 \mathrm{~m}$ wide and $283 \mathrm{~m}$ deep.
TABLE I. AMOUNTS OF HEADWARD EXTENSION OF VALLEYS, WITH DIVIDE DISPLACEMENT. (FOR REFERENCES, SEE [11])

\begin{tabular}{|c|c|c|}
\hline displacement & region & authors \\
\hline 1.5 to $3 \mathrm{~km}$ & $\begin{array}{l}\text { Terrace, West } \\
\text { Central B.C. }\end{array}$ & Hanson 1924 \\
\hline up to $2.5 \mathrm{~km}$ & $\begin{array}{c}\text { Shulaps Range, } \\
\text { B.C. }\end{array}$ & Evans 1972 \\
\hline 2 to $5 \mathrm{~km}$ & Bendor Range, B.C. & Evans 1972 \\
\hline 1 to $2 \mathrm{~km}$ & $\begin{array}{l}\text { Yohetta Range, } \\
\text { B.C. }\end{array}$ & Evans \\
\hline up to $1 \mathrm{~km}$ & $\begin{array}{c}\text { Kenai \& Talkeetna, } \\
\text { S. Alaska }\end{array}$ & Tuck 1935 \\
\hline up to $2.5 \mathrm{~km}$ & Sa. Nevada & $\begin{array}{l}\text { Brocklehurst \& Whipple } \\
2002\end{array}$ \\
\hline 0.9 to $4.4 \mathrm{~km}$ & Kyrgyz Ra., C. Asia & Oskin \& Burbank 2005 \\
\hline
\end{tabular}

Glacial cirques are eroded mainly by local mountain glaciers, and these lasted longer during the build-up of glacier cover (as deglaciation has normally been more rapid than build-up). Thus they provide valuable evidence of climatic conditions during the initiation of glaciation, a period for which glacial deposits are lacking [12, 13]. In Britain and Ireland, cirques are lower near west coasts, but low also near Irish Sea coasts in Wales, the Lake District and eastern Ireland (Wicklow, Mourne and MonavullaghComeragh Mountains). This implies environmental conditions colder but otherwise similar to the present day, with moisture (then snow, now rain) brought by west and southwest winds. Cirques near west coasts are also deeper, 
suggesting greater erosion by maritime glaciers with greater throughputs of ice.

In Scotland, Ireland, Wales and England we find both mountain ranges with intersecting ridges, where cirque development is lowering summits (e.g. the Cuillins and Snowdon), and others with summit plateaux above cirque crests (e.g. Cairngorms, Wicklows, Carneddau and High Street). The buzzsaw hypothesis is applicable to the former, but their proximity to the latter suggests that modern summit lowering has not been great. A third situation is found in the Helvellyn range, with cirques on the east slope lowering summits by eroding into the gentler west-facing slopes.

Romania has never suffered ice sheet glaciation, but its mountains are similar to Britain's in having a mixture of these three situations [5]. It is clear that the glacial buzzsaw operates locally, but not as universally as proposed by [6]. Its applicability may depend on the rate of uplift during the Quaternary and the initial height of mountains in relation to Quaternary snowlines.

\section{REFERENCES}

[1] R.A. Fernandez, J.B. Anderson, J.S. Wellner, R.L. Minzoni, B. Hallet, and R.T. Smith, "Latitudinal variation in glacial erosion rates from Patagonia and the Antarctic Peninsula $\left(46^{\circ} \mathrm{S}-65^{\circ} \mathrm{S}\right)$ " Geological Society of America Bulletin, vol. 128, no. 5-6, pp.10001023, 2016.

[2] F. Herman and M. Brandon, "Mid-latitude glacial erosion hotspot related to equatorial shifts in southern Westerlies” Geology, vol. 43, no. 11, pp. 987-990, 2015.

[3] V.K. Pedersen and D.L. Egholm, "Glaciations in response to climate variations preconditioned by evolving topography" Nature, vol. 493, pp. 206-210, 2013.
[4] S.G. Mitchell and D.R. Montgomery, "Influence of a glacial buzzsaw on the height and morphology of the Cascade Range in central Washington State, USA”, Quaternary Research, vol. 65, pp. 96-107, 2006.

[5] M. Mîndrescu and I.S. Evans, "Cirque form and development in Romania: Allometry and the buzz-saw hypothesis", Geomorphology, vol. 208, pp. 117-136, 2014.

[6] S.G. Mitchell and E.E. Humphries, "Glacial cirques and the relationship between equilibrium line altitudes and mountain range height”, Geology, vol. 43, pp. 35-38, 2015. doi: 10.113Q/G36180.1

[7] I.S. Evans, A.M. Hall and J. Kleman, "Glacial cirques and the relationship between equilibrium line altitudes and mountain range height: COMMENT", Geology, vol. 43, e366, 2015. doi: 10.1130/G36667C.1

[8] D.L. Egholm, S.B. Nielsen, V.K. Pedersen and J-E. Leseman, "Glacial effects limiting mountain height", Nature, vol. 460, pp. 884-888, 2009.

[9] I.S. Evans, "Inferring process from form: the asymmetry of glaciated mountains", in International Geography 1972, Adams W.P, and Helleiner F,M. (eds). University of Toronto Press: Toronto, vol. 1, 1972, pp. 17-19.

[10] I.D. Barr, J.C. Ely, M. Spagnolo, C.D. Clark, I.S. Evans, X.M. Pellicer, R. Pellitero and B.R. Rea, "Climate patterns during former periods of glacier initiation in Britain and Ireland: inferences from the cirque record" unpublished.

[11] I.S. Evans, "Local aspect asymmetry of mountain glaciation: a global survey of consistency of favoured directions for glacier numbers and altitudes”, Geomorphology, vol. 73, no. 1, pp.166184, 2006.

[12] I.D. Barr and M. Spagnolo, "Glacial cirques as palaeoenvironmental indicators: Their potential and limitations", Earth-Science Reviews, vol. 151, pp.48-78, 2015.

[13] Y. Crest, M. Delmas, R. Braucher, Y. Gunnell, M. Calvet and ASTER Team, "Cirques have growth spurts during deglacial and interglacial periods: Evidence from 10Be and 26Al nuclide inventories in the central and eastern Pyrenees”, Geomorphology, vol. 278, pp. 60-77, 2017. 


\title{
Karstification in the mountains Durmitor (Montenegro) and Pirin (Bulgaria) and its expression in surface landforms
}

\author{
Emil Gachev, Ilia Mitkov \\ South-west University "Neofit Rilski” \\ Blagoevgrad, Bulgaria
}

\begin{abstract}
The present study makes a comparison of the development of karstic processes and their landform expression in two representative high mountain areas on the Balkan Peninsula: Durmitor (Dinaric chain, Montenegro) and Pirin (Rhodope massif, Bulgaria). Main accent is put on epikarst and its features. On the background of many similarities: strong glaciation in the Pleistocene, pronounced cirques and arêtes, preserved moraine deposits, rough present-day topography, some obvious differences are observed. These are mostly derived by the differences in carbonate bedrock (limestone in Durmitor and marble in Pirin), and climate (damp to the west and drier to the east). The tectonic setting is also important. Such a comparison has not been done so far. It would contribute to obtain a better regional outlook on the processes in the high mountain karstic areas in Southeastern Europe.
\end{abstract}

Keywords - high mountain karst; Northern Pirin; Balkan Peninsula

\section{INTRODUCTION}

Karst processes generate a distinct type of environment, which is clearly distinguishable on the field. Apart from their high aesthetic attractiveness, karst areas are important for the formation of water resources and biodiversity. In South-eastern Europe, and in particular on the Balkan Peninsula, karst is wide spread (here is the homeland of classical Dinaric karst which has given the name to the whole variety of processes related to water dissolution of rocks).When speaking of high mountain karst however, we should admit that such areas provide some of the most spectacular landscapes in our region. If the term 'high mountain karst' is restricted to areas higher than $2000 \mathrm{~m}$ a. s. l., its distribution on the Balkan Peninsula will be much more limited. Two main areas can be outlined for this type of karst: Dinaric area to the west, with karst mainly in limestone, and Rhodope area to the east, predominantly in marbles (Fig. 1). Except in bedrock, the two areas differ considerably also in climatic conditions, the climate to the east being much drier. The high mountain karst areas selected for the present study: Durmitor and Pirin, are among the most representative for these areas.

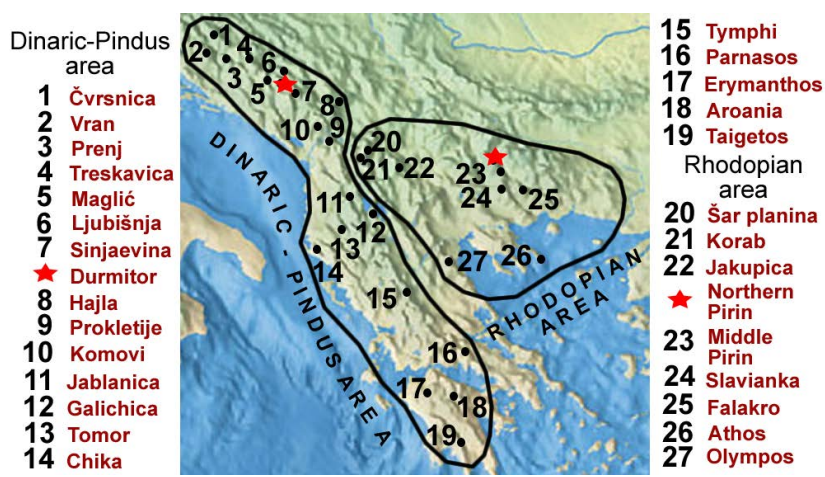

Fig. 1. Areas with high mountain karst on the Balkan Peninsula, and sites ofthe study.

\section{STUDY SITES}

\section{A. Geographical location}

Durmitor is situated in northwest Montenegro. This is the second highest massif in the Dinaric chain (after Prokletije in northern Albania), part of the central range, reaching to $2522 \mathrm{~m}$ (Bobotovkuk peak). This mountain is small, but sharply distinct: it rises abruptly over $1000 \mathrm{~m}$ above surrounding plateau surface at $1400-1600 \mathrm{~m}$ a. s. 1 . Nearby are the deepest gorges of Europe: Tara canyon to the north (depth down to $1340 \mathrm{~m}$ ), and Piva canyon to the west $(1100 \mathrm{~m})$ [1]. The main ridge of the mountain forms an arc opened to NE, with altitudes between 2300 and 2450 m. a. s. 1 .

Pirin lies in Southwest Bulgaria, in the central area of the vast Rhodope massif. This is the third highest mountain on the Balkan Peninsula (after Rila and Olympus), with the peak Vihren at $2914 \mathrm{~m}$ a. s. l. The mountain is much larger than Durmitor. It has generally a rhomboid shape, to the west and east it is framed by the deep valleys of Struma and Mesta rivers. Low passes separate it from its mountain neighbours Rila (2925 m to the north) and Slavianka (2212 $\mathrm{m}$, to the south).

\section{B. Geology}

The northern and central parts of Durmitor are made of thick Jurassic limestone. To the south cretaceous flysch formations are napped over the limestone, the nape line 
passing right on the southern slope of the subparallel main ridge. This is a factor for increasing the landform diversity of the mountain. Pirin is a horst structure of three Mesozoic granite intrusions, surrounded by a mantle of metamorphic rocks, which determine great diversity of landscape. Marbles compose parts of Northern Pirin (Vihren area, the highest section of the whole mountain). They are very thick and well stratified, with layers submerging towards NE. There are marbles also in Central Pirin, but altitude there barely reaches $2000 \mathrm{~m}$. a. s. 1 . Uniformity of marble rocks determine lower rate of landform diversity within the karst complex in Pirin compared to Durmitor.

\section{Relief}

The highest areas of both mountains have been shaped by the combination of glacial, periglacial and karst processes. They were heavily glaciated during the Pleistocene, but during the maximum glaciation the depression of the Equilibrium line altitude was greater in Durmitor (950-1000 m below the highest peaks, according to [2]) than in Northern Pirin (about 650-700 m [3]). In result, several deep cirques were carved on the northern side of both mountains, some of them also quite large. Exaration had much smaller effects on southern slopes. Today high mountain areas are dominated by periglacial processes and karstification, the latter being strongest over cirque bottoms, which are turned into labyrinths of sinkholes, small ridges and numerous caves.

\section{Climate}

Climate on both sites combines Mediterranean and temperate influences, which reflect their position close to the sea, but not adjacent to it. Being among the highest, these mountains are opened simultaneously to the south and to the north, to feel the climatic impacts of the Mediterranean and mainland Europe. Temperatures in both mountains are similar at same altitudes, maybe somewhat lower in Durmitor due to its more northern location. Temperatures have been gradually rising in the last decades [3, 4]. Precipitation regime in both areas is similar. Two maxima, in November-December and May-June, reflect the influences from NW (Atlantic cyclones) and SW (Mediterranean cyclones). Winter maximum is however stronger, and if the year is divided into two, it will appear that about $2 / 3$ of precipitation falls in the cold half of it, mainly as snow for the altitudes above $2200 \mathrm{~m}$. The studied locations differ most in the total amount of precipitation. The annual sum in Durmitor is 2.5 times higher than that in Pirin (2500-2600 mm vs $1000-1100$ $\mathrm{mm})$ [5].

\section{COMPARISON OF SURFACE KARST LANDFORMS BETWEEN DURMITOR AND PIRIN}

Surface landforms in Durmitor are representative for the Dinaric karst. Here cirque bottoms, and also low slopes, are deeply karstified. Corrosion has produced very rough topography, but the surfaces of the numerous hills and sinkholes are smooth and rounded. Line rill corrosion microforms cover steep rock faces. These are narrow channels with a width in order of 2-10 cm and depth 5-15 $\mathrm{cm}$, which run vertically, parallel to each other. Surface karst processes also have strong influence on mountain summit surfaces, which are flat in the eastern section of the mountain (Šlijeme plateau). Large and deep sinkholes can be found there, the most spectacular being "The snowy sinkhole" (Snežna vrtača). Stone arches and small canyons enrich the topography of the plateau. Physical (frost) weathering is more active on steep slopes and in couloirs (due to the greater gravitation instability of rocks) and in shaded locations, where temperatures cross $0^{\circ} \mathrm{C}$ most of the days of the year. Physical destruction of limestone produces extensive screes and colluvial fans with debris mainly of pebble size.

Compared to Durmitor, environment in the karstic areas of Northern Pirin possesses some characteristics that implies on a similarity to the periglacial landscape in silicate rocks. For example, although carbonate in composition, marble is at the same time a crystalline rock. It has strata like limestone, but disintegrates to larger blocks like granite or gneiss. Therefore, the screes formed have a prevalence of larger sized debris. Such accumulations allow for cold air and water to penetrate and store inside, and even freeze there and produce bulges of a rock glacier type. Inside cirques, epikarst features are present, but they are not so pronounced as in Durmitor, neither on the bottom, nor along slopes. There are two reasons for this: first, the much lesser amount of precipitation, and second, the higher altitude of cirques in Pirin, which resulted from the $600 \mathrm{~m}$ higher level of ELA during the coldest phases of the Pleistocene. Higher elevation means lower temperature, which increase the percentage of snow precipitation and enhances frost weathering. In the marble cirques of Northern Pirin karstification prevails only within the sinkholes in the deepest part of cirque bottoms where snow retains for 7-8 months a year. Main karstification agent is snow melt water. Predominance of karstification over frost action at these sites is indicated by the rounded shape of large stone blocks, with recesses in a crossed pattern that follow the crystalline type cracks in marble. Parallel microforms are not formed on slopes due to small rainfall amounts. Both on slopes and ridges frost action prevails over corrosion, and this is enhanced in the highest slopes and ridges with altitude above $2800 \mathrm{~m}$ a. s. l. There, due to the extreme rates of frost action, bedrock is stirred on small loose blocks, resembling "halva” dessert (a landscape untypical for Durmitor). Both sites have similarities in bare rock faces, which surfaces are tall and smooth, in the abundance of couloirs, and the general topography of macroforms cirques and ridges.

\section{GLACIOKARST FEATURES OF SPECIAL INTEREST}

Current presence of small glaciers is by no doubt something that Durmitor and Pirin have in common. Two glacierets are situated in the high cirques of Northern Pirin: Snezhnika glacieret (2400-2450 m a. s. 1., $0.6 \mathrm{ha}$ ) under the NE wall of Vihren peak, and Banski suhodol (2610-2700 $\mathrm{m}, 1.1$ ha) below the second highest summit in Pirin, Kutelo (2908 m) [5]. These are the southernmost glacial masses in Europe at present [6]. Debelinamet (2.5 ha) is the only small glacier in Durmitor [7]. Much higher precipitation in the Dinarides allow for the glacier to persist at surprisingly low altitudes (2035-2200 m a. s. 1.). Small glaciers that exist at present on the Balkans are in fact products of karstification. In such thermal conditions (annual air temperatures $+1^{\circ} \mathrm{C}$ and above) they would not exist away from the light colored carbonate bedrock, and its surface karst, which provides for instant drainage of 
melt waters, keeps firn/ice masses relatively cool and dry during ablation season, and hinders rapid melting. Therefore, small glaciers in Pirin and Durmitor can be considered specific elements of high mountain epikarst environment.

Also specific for Durmitor are several small lakes, which formation should be addressed to the existence of tiny layers of other rocks between the limestone strata. In Pirin, there are some lakes in areas bordering the marble (e. g. Sinanishkoezero), but not within the karst area.

\section{Conclusions}

High mountain karst in Durmitor and Pirin have lots of similarities and some differences, but the former prevail over the latter. These are specific environments with alpine character of relief, rough topography, lack of surface running waters, but presence of perennial snow and ice. Mainly due to the much higher precipitation amounts, karstification in Durmitor is more intense and plays a bigger role in the formation of high mountain relief. On the contrary, the crystalline character of marble and the colder conditions, resulting from the higher altitude, determine the prevailing share of physical weathering (frost heave) in the formation of morphosculpture in the highest areas of the karstic part of Pirin. Chemical denudation there is stronger only in deep depressions.

\section{REFERENCES}

[1] B. Cerović, Durmitor i kanjon Tare.Vodič. Beograd, 1991. (in Serbian)

[2] P. Djurović, "Reconstruction of the Pleistocene glaciers on Mount Durmitor in Montenegro”, Acta Geographica Slovenica, vol. 49, no. 2, pp. 263-289, 2009.

[3] V. Popov, Pirinplanina s dolinatana Mesta. Geography of Bulgaria, vol.1, 1966. (in Bulgarian)

[4] P. Djurović, Visokoplaninskikras Durmitora. Beograd, 2011. (in Serbian)

[5] P. Nojarov, "Modeling of climate changes in Rila and their impact on Seven Rila lakes", in Eighth Scientific Conference Space, ecology, safety, Sofia, 4-6 Dec. 2012, pp. 391-401.

[6] E. Gachev, K. Stoyanov, and A. Gikov, "Small glaciers on the Balkan Peninsula: state and changes in the last several years", Quaternary International, vol. 415, pp. 33-54, 2016.

[7] K. Grunewald and J. Scheitchauer, "Europe's southernmost glaciers: response and adaptation to climate change”, Glaciology, vol. 56, pp. 129-142, 2010.

[8] P. Djurović, "The Debelinamet glacier from the second half of the 20th century to present”, Acta Geographica Slovenica, vol. 52, no. 2, pp. 277-301, 2012.
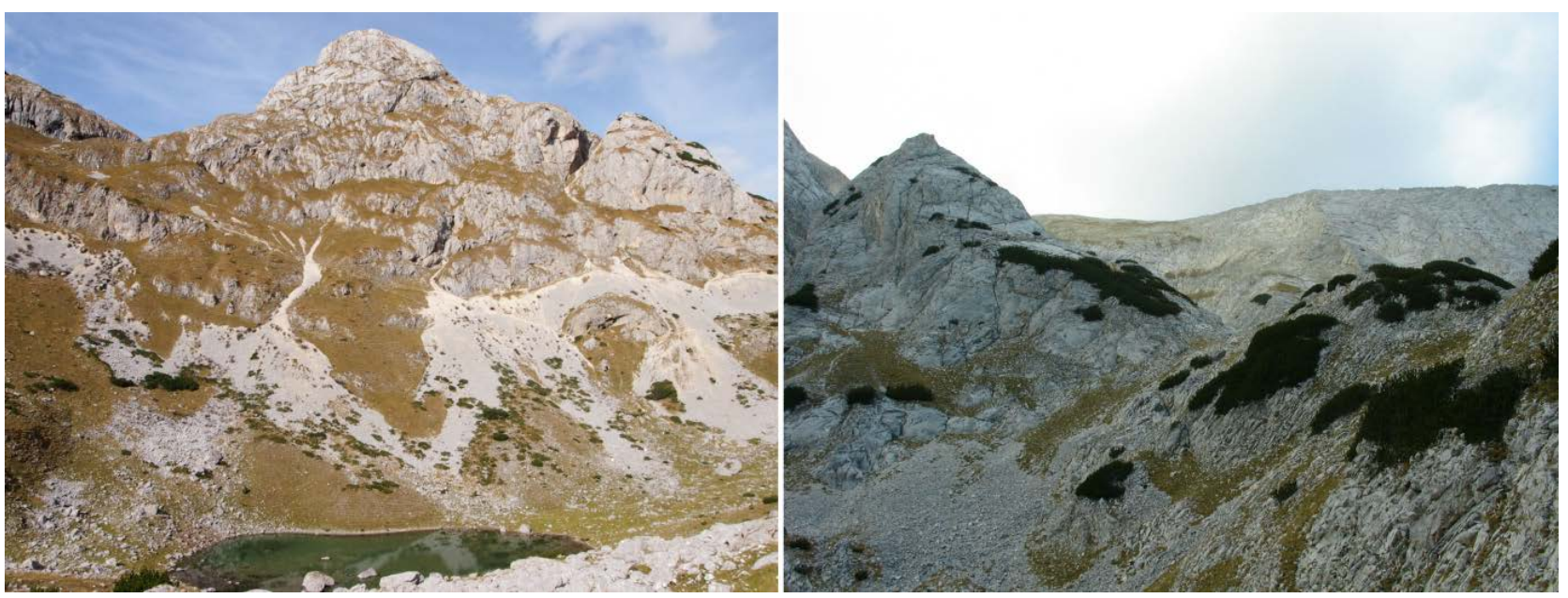

Fig. 2. Typical epikarst features in Durmitor (left): corroded slopes, pebble-grain screes and a lake; and Pirin (right): boulder-size screes and slopes with weaker karstification and higher physical weathering. 


\title{
Spatial distribution and controlling factors of snow avalanche and debris flow in Parâng Mountains
}

\author{
Ionela Georgiana Gavrilă, Olimpiu Pop, Csaba Horvath, Flaviu Meseșan, Iulian Holobâcă \\ Faculty of Geography \\ Babeș-Bolyai University \\ Cluj-Napoca, Romania
}

\begin{abstract}
The alpine slopes of Parâng Mts. are prone to snow avalanche (SA) and debris flow (DF) activity due to favorable lithological, topo-climatic and vegetation cover conditions. Since tourism activities are continuously increasing, tourists and related infrastructure in this area might be exposed to different levels of risk. Our study is a preliminary research that aims to analyze the spatial distribution and controlling factors of SA and DF processes in Parâng Mts., which represent natural hazards threating the areas destined for tourism activities and associated infrastructure. First, the spatial distribution pattern of SA paths and DF tracks was identified and mapped on orthophotoplans, then checked in the field and integrated in a database for analysis. Subsequently, a set of instability factors influencing directly the spatial distribution of SA and DF activity were analyzed. The following instability factors were taken into consideration and statistically analyzed using ArcGIS software: slope, altitude, aspect, planar and profile curvature (automatically extracted from $10 \mathrm{~m}$ resolution DEM), vegetation cover (mapped on orthophotoplans) and lithology (extracted from the geological maps at 1:200.000 scale). Information regarding the spatial distribution of tourist frequented areas and the related infrastructure (hiking trails, chalets, ski lifts, ski pistes etc.) were analyzed in conjunction with the spatial distribution of geomorphic process activity. In areas with tourism activities, future research will focus on mapping terrain susceptibility to SA and DF processes. Moreover, dendrogeomorphic reconstructions will allow to determine the occurrence probability of SA and DF activity, which will serve to finally get an accurate geomorphic hazard zonation within the study area.
\end{abstract}

Keywords - spatial distribution; controlling factors; snow avalanche; debris flow; Parâng Mountains; ZonaGeoTour

\section{INTRODUCTION}

In the present-day period, an increase of snow avalanche (SA) and debris-flow (DF) activity was reported in various massifs belonging to Carpathian range, causing material damages and fatalities in inhabited areas [1], [2], [3], [4], [5]. So far, in Parâng Mts., only SA activity was investigated and reported in few case studies by [1] and [6], even if both geomorphic processes are widespread on the alpine and subalpine steep slopes of the massif being natural hazards threating the touristic areas and related infrastructure.

Within the present context of tourism planning policies regarding the extension of tourism infrastructure in investigated area, a better understanding of behavior of SA and DF geomorphic processes is crucial for the mitigation of hazards and associated risks.

Our study is the first stage of the geomorphic hazard assessment in areas frequented by tourists from Parâng Mts. It aims to analyze the spatial distribution and instability factors which control the SAs and DFs. This research also aims at identifying those touristic areas and associated infrastructure exposed to geomorphic hazards.

\section{STUDY AREA}

Parâng Mts. belongs to Southern Carpathians, reaching the maximum altitude in Parângul Mare Peak (2519 m a.s.l.). For our study we took into consideration the high areas of Parâng Mts. where peaks, narrow crests and steep slopes are common, being prone to geomorphic activity. The total surface of study area is $195.5 \mathrm{~km}^{2}$. In terms of lithology, magmatic rocks (granites and granodiorites) are widespread in the highest part of the mountains, while metamorphic and sedimentary rocks (amphibolite, crystalline schists, limestone) are common at its periphery [7]. Overall morphology is represented by narrow ridges, glacial cirques and valleys etc., being the result of Pleistocene and Holocene glacial and periglacial activity. The pre-existing glacial and periglacial landforms are reshaped in the present-day by SA and DF geomorphic activity [7] and [1]. Above $1800 \mathrm{~m}$ a.s.l., the average annual temperature is below $2^{\circ} \mathrm{C}$ and the precipitation amount is $1200 \mathrm{~mm} /$ year, leading to the development of alpine shrubs and alpine meadow. Between 1400-1700 m the average annual temperature is around $2-3^{\circ} \mathrm{C}$ and precipitation amount is about 1000-1200 mm/year. Coniferous belt extent roughly at mentioned altitudes, being dominated by Norway spruce (Picea abies (L.) Karst.) forests [6]. 


\section{METHODS}

In order to achieve the proposed goal of our study, first, the spatial distribution pattern of SA paths and DF tracks was identified and mapped as polygons on orthophotos. The preliminary inventory map was then partially checked and corrected in the field. In this stage, field observations were also made in the areas with high density of SA path and DF tracks to obtain information regarding instability factors involved in the process initiation.

The following controlling factors were subsequently took into consideration for analysis: slope, altitude, aspect, planar and profile curvature, vegetation land cover and lithology. Slope, altitude, aspect, planar and profile curvature were automatically derived from $10 \mathrm{~m}$ resolution DEM; while lithology was extracted from the existing geological maps at 1:200.000 scale. Vegetation cover was identified and mapped on orthophotos in 6 different classes: forest vegetation; forest and subalpine shrubs; subalpine shrubs; shrubs and alpine meadows; subalpine meadow; bare rock; and secondary pasture. In this stage, the tourism infrastructure (hiking trails, chalets, ski lifts, ski pistes etc.) was also mapped using the orthophotos.

Statistical analyses were completed in order to assess the role of each instability factor on the spatial distribution of SA and DF using two different methods.

In case of SA, within mapped polygons, only the areas with slopes above 250 were considered as starting zones. Through spatial analysis, the area of every class of the instability factors was measured and by using ArcGIS 10, Spatial Analyst Tools toolbox "Zonal/Tabulate Area" extension, the affected part of them was computed.

In case of DF the exact initialization of process was identified and represented as point. ArcGIS 10 software was used to count the number of points of DF source areas within each class using spatial analysis. The instability factors took into consideration in this case were the same, without lithology.

Subsequently, in order to identify the vulnerable areas to geomorphic hazard, information regarding the spatial distribution of areas frequented by tourists and the related infrastructure were analyzed in conjunction with the spatial distribution of SA and DF activity.

\section{RESUlts}

In total, 43 SA starting areas and 1459 DF source zones were identified in Parâng Mts. The statistical results shows that SA starting areas are mainly located above $2000 \mathrm{~m}$, on steep slopes over $25^{\circ}$, in cirque walls or glacial valleys. The most SA starting areas are located on slopes southwest, south and south-east oriented due to the favorable topo-climatic conditions (high insolation, increased air temperature) (tab. 1). Regarding the vegetation cover, the most SA starting areas is on steep slopes situated above treeline, covered with alpine shrubs, alpine meadows and bare rock.

The highest density of DF source zones is between $1600-1800 \mathrm{~m}(42.36 \%)$, on steep slopes ranging between $20^{\circ}$ to $40^{\circ}$ (1.090 DF source zones, representing $74,7 \%$ from the total number) (tab. 2). DF source zones mainly correspond with the steep slopes of bare rock (42.5\%), represented by granites and granitoides (46.9\% from the total number of inventoried DF source zones) or poorly consolidated debris slopes. The cliff faces also helps to concentrate the runoff into talus surfaces, being an important controlling factor of DF.

Data resulted from analysis between spatial distribution of geomorphic processes and tourism infrastructures revealed that from a total length of $174 \mathrm{~km}$ of hiking trails, $14 \mathrm{~km}$ are exposed to SAs.

TABLE I. ASPECT OF DEBRIS FlOW STARTING ZONES IN PARÂNG MTS

\begin{tabular}{|l|l|c|c|}
\hline No. & Aspect & $\begin{array}{c}\text { Surface of } \\
\text { starting zone } \\
\left(\mathbf{k m}^{\mathbf{2}} \mathbf{)}\right.\end{array}$ & $\begin{array}{c}\text { Percentage } \\
\mathbf{( \% )}\end{array}$ \\
\hline 1 & Flat & 0 & 0 \\
\hline 2 & N & 1.04 & 10.4 \\
\hline 3 & NE & 1.59 & 11.1 \\
\hline 4 & E & 2.24 & 12.1 \\
\hline 5 & SE & 2.33 & 11.2 \\
\hline 6 & S & 2.75 & 12.1 \\
\hline 7 & SW & 3.82 & 13.5 \\
\hline 8 & W & 2.94 & 15.7 \\
\hline 9 & NW & 1.17 & 13.9 \\
\hline & Total & 17,88 & 100 \\
\hline
\end{tabular}

TABLE II.

SLOPE ANGLES OF DEBRIS FLOW SOURCE ZONES IN PARÂNG MTS.

\begin{tabular}{|l|l|c|c|}
\hline No. & \multicolumn{1}{|c|}{ Slope angles $\left.\mathbf{(}^{\circ}\right)$} & $\begin{array}{c}\text { Number of DF } \\
\text { tracks }\end{array}$ & $\begin{array}{c}\text { Percentage } \\
(\mathbf{\%})\end{array}$ \\
\hline 1 & $<20$ & 166 & 11.4 \\
\hline 2 & $20-30$ & 565 & 38.7 \\
\hline 3 & $30-40$ & 525 & 36.0 \\
\hline 4 & $>40$ & 203 & 13.9 \\
\hline & Total & 1459 & 100 \\
\hline
\end{tabular}

\section{CONCLUSIONS AND PERSPECTIVES}

The spatial and statistical analyses reveal that morphometric parameters, vegetation cover and lithology highly control the spatial distribution of SA and DF in Parâng Mts. Touristic infrastructure and related activities are exposed to geomorphic hazards, therefore the monitoring of processes and hazard assessment is compulsory for tourist safety. In the areas with tourist activities, future research will focus on mapping terrain susceptibility to SA and DF processes. Moreover, the occurrence probability of both geomorphic activity will further be assess using dendrogeomorphological methods. This data will serve to obtain an accurate geomorphic hazard zonation in the Parâng Mts.

\section{ACKNOWLEDGMENT}

This work has been supported from the Bilateral Project ZONAGEOTOUR " Zonage des aléas géomorphologiques dans les espaces touristiques des massifs du Parâng (Roumanie) et du Pirin (Bulgarie) » (Geomorphic hazard zonation in tourism areas of Parâng Mts., Romania and Pirin Mts., Bulgaria), financed by the 
Agence Universitaire de la Francophonie (AUF) and Fonds de Recherche Scientifique (FRS) de Bulgarie.

\section{REFERENCES}

[1] O. T. Pop, I. G. Gavrilă, G. Rosian, F. Mesesan, A. Decaulne, I. H. Holobâcă and T. Anghel, "A century-long snow avalanche chronology reconstructed from tree-rings in Parâng Mountains (Southern Carpathians, Romania)", Quaternary International, vol. 415, pp. 230- 240, 2016.

[2] M. Voiculescu, "Snow-avalanche hazards in the Făgăraş Massif (Southern Carpathians): Romanian Carpathians-Management and perspectives", Natural Hazards, vol. 51, pp. 459-475, 2009.
[3] J. Hreško, G. Bugár, M. Boltižiar, and F. Kohút, "The dynamics of recent geomorphic processes in the Alpine zone of the Tatra Mountains", Geographia Polonica, vol. 81, no. 1, pp. 53-65, 2008.

[4] A. Kotarba, "Geomorphic activity of debris flows in the Tatra Mts and in other European Mountains", Geographia Polonica, vol. 80, no. 2, pp. 137-150, 2007.

[5] Z. Rączkowska, "Recent geomorphic hazards in the Tatra Mountains", Studia Geomorphologica Carpatho-Balcanica, vol. 40, pp. 45-60, 2006.

[6] F. Meseșan, O. Pop, I.G. Gavrilă and D. Petrea, "Snow avalanche activity in Parâng ski area revealed by tree-rings", Studia Geographia, vol. LIX, no. 2, pp. 47-56, 2014.

[7] R. Popescu, A. Vespremeanu-Stroe, A. Onaca, and N. Cruceru, "Permafrost research in the granitic massifs of Southern Carpathians (Parâng Mountains)", Zeitschrift für Geomorphologie, vol. 59, no. 1, pp. 1-20, 2015 


\title{
The dynamics of the Danube channel
}

\section{over the last 150 years}

\author{
(Giurgiu - Călăraşi sector. Preliminary data)
}

\author{
Florina Grecu, Gabriela Ioana-Toroimac, Ștefania \\ Grigorie (Omrani) \\ Faculty of Geography \\ University of Bucharest \\ Bucharest, Romania \\ florinagrecu@yahoo.com, \\ gabriela.toroimac@geo.unibuc.ro, \\ stefania_grigorie@yahoo.com
}

\author{
Cristina Ghiță \\ School Inspectorate of Ilfov County \\ I.S.J. Ilfov \\ Bucharest, Romania \\ chrys_geo_2007@yahoo.com
}

\begin{abstract}
The dynamics of a river channel targets the interdependency relations between water, relief and sediments, as well as their effects within the fluvial system. This paper presents the dynamics of some fluvial islands (islets) from the river channel of the Danube between Giurgiu-Russe and Călărași-Silistra localities, corresponding to a part of the lower sector of the Danube, which constitutes the border between Romania and Bulgaria. The islets are fixed sedimentary deposits, stabilized, with a vegetation cover depending on the soil formation degree. We use the term "ostrov", as specified on the cartographic materials published in Romanian. The objectives of the study are defined by the main work phases: 1) identification and mapping of islets on maps of 1864, 1910, 1980 and on orthophotoplans of 2009,2 ) design of a typology of these islets based on various criteria, 3) determination of the surface evolution of some islets relevant both as position and as morphogenetic environment. The analysis highlights the ascending variation of the surface of the islets both in time and in space, in respect to the sedimentary input of the Danube. A conclusive example is the Kosuy islet, situated upstream of the Argeș-Danube confluence (between kilometers 427-423 on the Danube), with an area which increased over five times in the last 150 years.
\end{abstract}

Keywords - dynamics; morphometry; mapping; fluvial island; the Danube; Romania

\section{INTRODUCTION}

The Danube crosses Central Europe from West to East and it is the second longest river in Europe. The total length is $2780 \mathrm{~km}$ and it has a basin area of $805300 \mathrm{~km}^{2}$.

On Romania's territory (lower sector), it has a length of $1075 \mathrm{~km}$ (between localities Baziaș and Sulina) of which $800 \mathrm{~km}$ form the border with Serbia, Bulgaria, Moldova, Ukraine, and $275 \mathrm{~km}$ are exclusively in Romania, with two large islands transformed into agricultural polders. The Danube drains 93\% of the Romanian territory and flows into the Black Sea through a delta, which is a Man and Biosphere reserve. In Romania, the Danube lower course presents distinctiveness on sectors (major for the economy): the Danube Carpathian Gorge, river sector, river-sea sector, maritime.

The main objectives of this study outcome from the following working stages: understanding the key factors influencing the riverbed dynamics, inventorying, mapping and classifying morphometrically the islands ("ostroave"), as well as assessing the dynamics of large area islands in the last 150 years. Within the study, the Danube sector in Romania is limited by the Romanian Plain in the north, by the Pre-Balcanic Plateau in the south and forms the border with Bulgaria.

The geological characteristics are given by the following deposits: alluvial deposits, floodplain and terraces deposits, marsh deposits from Pleistocene and Holocene: sands, silts, loess-like deposits etc. It is part of a plain from southern Romania - the Romanian Plain - with terraces relief, floodplain and river channel (Fig. 1), anthropically transformed by deforestation, diking, construction etc. [1].

The temperate continental climate presents great contrasts between summer and winter and excessive episodes dependent on the circulation of the air masses from Europe. This causes successive episodes of flooding (2006) and / or drought. The natural vegetation covers the islands, depending on the soil formation degree.

\section{HYDROGEOMORPHICS FAVOURABILITY FACTOR}

The Danube cross-section profile of the river channel (1993-2012) reveals two sectors with different characteristics, located west and east of the Giurgiu city. An erosion tendency can be observed towards the right shore and accumulations on the left side of the river.

At Giurgiu, the cross-section profile asymmetry becomes more noticeable, the maximum depth being on the left side. Downstream, at Chiciu, the asymmetry changes in favour of large depths towards the right shore 
(Fig. 2). The river channel indicates minor variations of morphometric parameters (1993-2012) (Table 1).

TABLE I. MAIN MORPHOMETRIC DATA OF THE RIVER CHANNEL

\begin{tabular}{|c|c|c|c|c|c|c|c|c|c|c|c|c|}
\hline \multirow{2}{*}{ 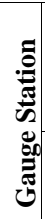 } & \multicolumn{3}{|c|}{$\begin{array}{c}\text { Cross } \\
\text { sectional } \\
\text { area }(\mathrm{m} 2)\end{array}$} & \multicolumn{3}{|c|}{ Width (m) } & \multicolumn{3}{|c|}{$\begin{array}{c}\text { The average } \\
\text { depth } \\
\text { (surface/width) } \\
\text { (m) }\end{array}$} & \multicolumn{3}{|c|}{$\begin{array}{l}\text { Maximum } \\
\text { depth (m) }\end{array}$} \\
\hline & $\stackrel{\Re}{2}$ & §ิ & సิ & $\stackrel{\Re}{\stackrel{2}{-}}$ & §ิ & ลี & ळે & §ิ & $\underset{\text { ปิ }}{ }$ & $\stackrel{\Re}{\stackrel{2}{-}}$ & §ิి & $\underset{\sim}{\sim}$ \\
\hline 总 & $\stackrel{\infty}{\text { fo }}$ & $\begin{array}{c}\widetilde{N} \\
\mathscr{+}\end{array}$ & 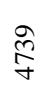 & $\check{D}$ & 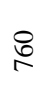 & 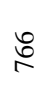 & 7 & $\ddot{n}$ & 7 & $\stackrel{0}{0}$ & $\stackrel{\text { Nִ }}{\beth}$ & $\begin{array}{l}\infty \\
\stackrel{0}{-1}\end{array}$ \\
\hline نق. & 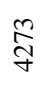 & के & ô & 守 & 导 & $\stackrel{\infty}{N}$ & is & $\stackrel{\infty}{\infty}$ & $\stackrel{+}{\dot{0}}$ & $\underset{\infty}{\infty}$ & $ㅇ$ & $\stackrel{\nabla}{\sigma}$ \\
\hline
\end{tabular}

The longitudinal profile of the riverbed drops below 0 $\mathrm{m}$ in some places, reaching $-30 \mathrm{~m}$ absolute altitude. Depending on the position of the riverbed, the water depth ranges from 4 to $10-11 \mathrm{~m} \mathrm{[3].}$

The existence of the bottom silts explains the average and the maximum depth at Chiciu (downstream) lower than at Giurgiu; the situation is reflected by the island forming process (Table 1, Fig. 2). The floodplain has a variable width, from less than a kilometer to over $10 \mathrm{~km}$ (the maximum width is $30 \mathrm{~km}$ in the ramification sector of Călărași and Brăila). The relative altitude gradually decreases along the river (downstream Oltenița, it exceeds $3 \mathrm{~m}$ at the average Danube level) [2]. The meadow is delimited by terraces, whose number decreases from West to East (Fig. 1 and 5).
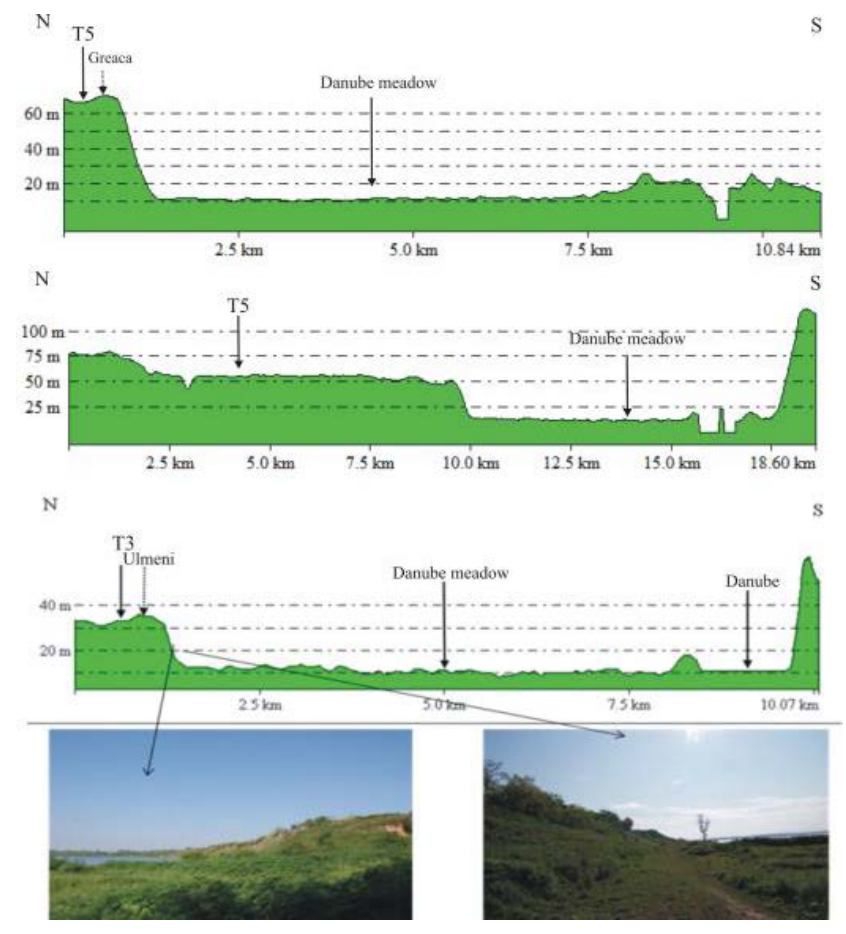

Fig. 1. Cross-section through the Danube valley (Greaca, Chirnogi, Ulmeni).

The lower terrace is spreading along the river between Baziaș and Brăila; its altitude varies from 5-6 m to 12-13 $\mathrm{m}$ being occupied by towns and villages, which have expanded into the meadow, being exposed to flood risk.

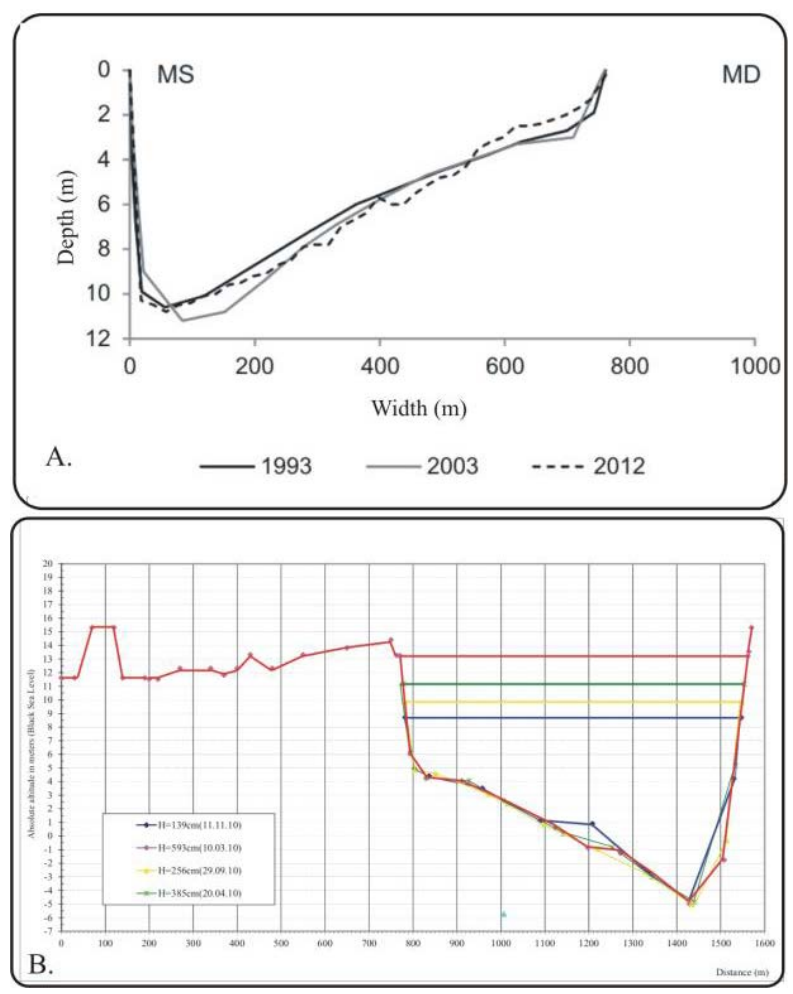

Fig. 2. Cross-sections through the river channel of the Danube at Giurgiu (A) and Chiciu (Călărași) gauging stations (B) (based on data from A.N.A.R - Administrația Națională Apele Române).

Solid flow - sediments: the decreasing trend of sediments amount after completing upstream hydraulic structures (dams and reservoirs of Iron Gates I and II) seriously affects the material source for islands (Fig. 3) [3].

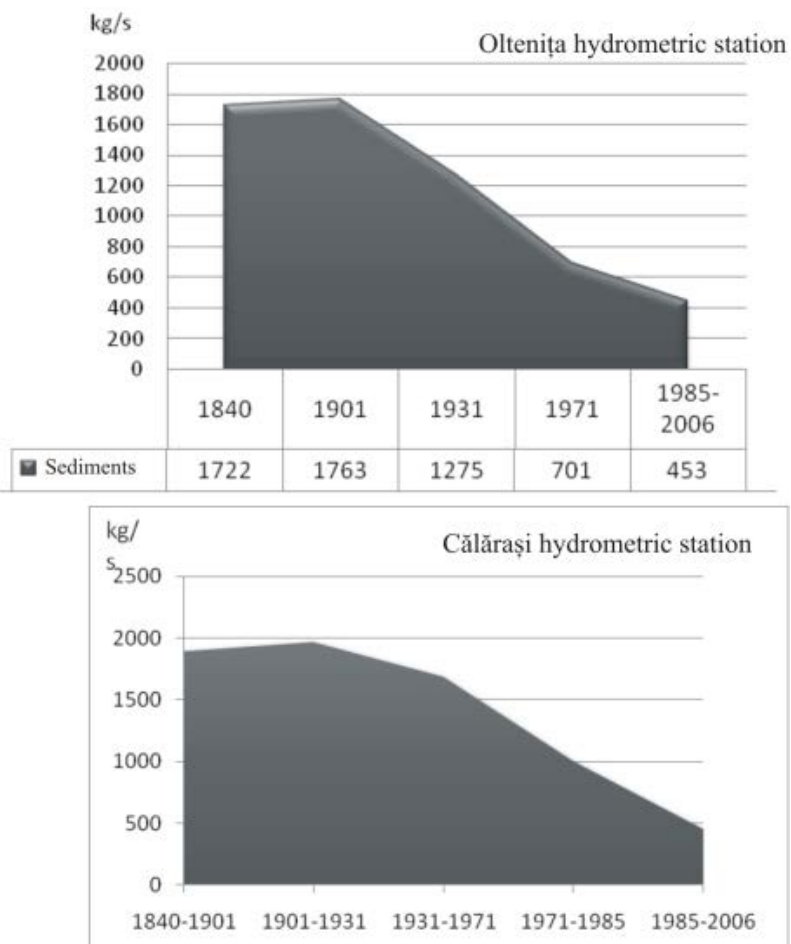

Fig. 3. Solid flow evolution - Oltenița and Călărași gauging stations (1840-2006) (based on data from A.N.A.R) 
The case studies target the islands located downstream confluences, where the influx of sediments is high (Ostrov Kosuy - Argeș, Ciocănești island - Mostiștea).

\section{METHODS AND CARTOGRAPHIC MATERIALS USED}

Programs used: QGIS 2.2, ArcGIS 10.1. Global Mapper 15. Methods: geomorphological mapping, hydrology, hydrogeomorphic, observation, analysis, investigation and aerospace instrumental method, diachronic research (Table 2) etc.

TABLE II. DATA SOURCES

\begin{tabular}{|c|c|c|c|}
\hline Type & $\begin{array}{c}\text { Scale / } \\
\text { Resolution }\end{array}$ & Year & Data source \\
\hline \multicolumn{4}{|c|}{ Historical maps } \\
\hline Szatmary Map & $1: 57600$ & 1864 & $\begin{array}{c}\text { http://www.charta1864.ro/c } \\
\text { harta.html }\end{array}$ \\
\hline $\begin{array}{c}\text { Austrian } \\
\text { Empire map }\end{array}$ & $1: 200000$ & 1910 & http://www.earth.unibuc.ro \\
\hline $\begin{array}{c}\text { The Gauss - } \\
\text { Krüger } \\
\begin{array}{c}\text { Topographic } \\
\text { map }\end{array}\end{array}$ & $1: 25000$ & 1980 & http://opengis.unibuc.ro \\
\hline \multicolumn{3}{|c|}{ Aerial image uses in GIS } \\
\hline $\begin{array}{c}\text { Orthophotopla } \\
\text { ns }\end{array}$ & 5 m & 2009 & $\begin{array}{c}\text { Optical spectral bands } \\
\text { SC BLOM ROMANIA } \\
\text { SRL }\end{array}$ \\
\hline $\begin{array}{c}\text { SRTM } \\
\text { (Shuttle Radar } \\
\text { Topography } \\
\text { Mission) }\end{array}$ & $1: 100000$ & 2000 & http://www.earth.unibuc.ro \\
\hline
\end{tabular}

\section{ISLANDS INVENTORY}

There are differences between the two sectors in terms of area of the islands, which can be explained by morphometric particularities of the river channel and the floodplain. In the Giurgiu-Oltenița sector there are 18 islands, generally with large surfaces, four of them exceeding $5 \mathrm{~km}^{2}$ and they are located immediately downstream from Giurgiu (probably tectonic factors) (Table 3). In the Oltenția and Călărași sector, the small size surface makes many of the 11 islands to be submerged during floods [1].

TABLE III. ISLANDS: GIURGIU - CĂLĂRAȘI SECTOR

\begin{tabular}{|c|c|c|}
\hline No. & Island name & Danube km \\
\hline 1. & MOKAN & $489-482$ \\
\hline 2. & MARTEN & $480-477$ \\
\hline 3. & ALEKO & $478-472$ \\
\hline 4. & GOSTIN & $475-474$ \\
\hline 5. & LUNGU & $469-464$ \\
\hline 6. & MISHKA & $460-458$ \\
\hline 7. & TUTRAKAN & $434-433$ \\
\hline 8. & KOSUY & $428-424$ \\
\hline 9. & MALAK KOSUY & $425-422$ \\
\hline 10. & ALBINA & $414-411$ \\
\hline 11. & GARVANOVI & $411-408$ \\
\hline 12. & VĂRĂȘTI & $403-401$ \\
\hline 13. & CIOCĂNEȘTI & $397-393$ \\
\hline 14. & DEVNYA & $396-394$ \\
\hline 15. & OSTROV & $388-387$ \\
\hline 16. & PESCĂRUȘUL 1 & $387-386$ \\
\hline 17. & CHAYKA & 388 \\
\hline 18. & PASTRAMAGIU & $379-375$ \\
\hline 19. & HOPA & $378-371$ \\
\hline 20. & JIANU & $376-373$ \\
\hline
\end{tabular}

\section{RESUltS AND CONCLUSIONS}

The number, the density and the size of the islands are relying on the contribution of sediments. The islands surfaces registered a general increasing trend. A rise in the surface of the islands was observed during the period between 1910 and 1950, followed by a stagnation, reduction or a very low growth (Table 4). The large islands have continued to expand but with reduced average rates. Topographically, the islands change their appearance depending on the water dynamics and the position to the shoreline. A conclusive example is the Kosuy islet, situated upstream the Argeș-Danube confluence (between kilometers 427-423 on the Danube), with an area that increased over five times in the last 150 years (Fig. 4).

The alluvial terrace has a lower altitude downstream from $20 \mathrm{~km}$ at Giurgiu to $15-17 \mathrm{~km}$ at Greaca, $10-13 \mathrm{~km}$ at Oltenița and less than $10 \mathrm{~km}$ at Ulmeni (Fig. 1) [7].

The dynamics of the river channel is limited by diking. According to the system theory, the water flow through a channel maintains a relatively stable geomorphometry at a constant discharge [5, 6]. Diking affects the relations between the flow and the floodplain (Fig. 5) [7], the systemic connection existing only at high flow levels. Thus, sediments are deposited laterally or axially on the bottom of the riverbed, reducing the water depth and creating islets of various sizes and/or lateral deposits.

TABLE IV. CHANGES / YEAR RECORDED AT HE SURFACE OF THE ISLAND $\left(\mathrm{KM}^{2}\right)[4]$

\begin{tabular}{|c|c|c|c|c|c|c|c|c|}
\hline \multirow[b]{2}{*}{ Islands } & \multirow[b]{2}{*}{ छे } & \multirow[b]{2}{*}{ 음 } & \multirow[b]{2}{*}{ 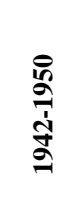 } & \multirow[b]{2}{*}{$\begin{array}{l}\text { : } \\
\text { Ф }\end{array}$} & \multirow[b]{2}{*}{ 옹 } & \multicolumn{3}{|c|}{ Changes/year } \\
\hline & & & & & & 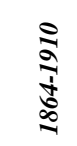 & ڤొ & 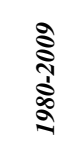 \\
\hline Albina & 2.19 & 5.0 & 4.8 & 0.72 & 0.51 & +2.81 & -4.08 & -0.21 \\
\hline Garnovari & 1.2 & 0.83 & 0.56 & 1.7 & 1.4 & -0.37 & +1.14 & -0.3 \\
\hline Ciocănești & 0.29 & 0.41 & 0.58 & 1.83 & 2.19 & +0.12 & +1.25 & +0.36 \\
\hline Нора & 1.16 & 2.4 & 1.8 & 2.55 & 5.05 & +1.24 & +0.75 & +2.5 \\
\hline
\end{tabular}

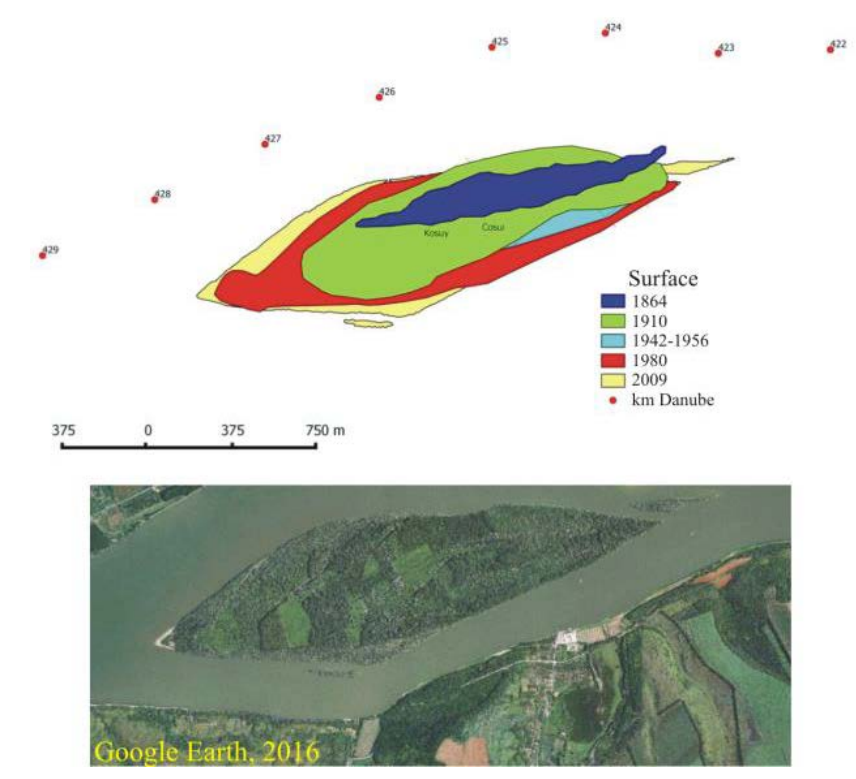

Fig. 4. Kosuy island in the last 150 years. 


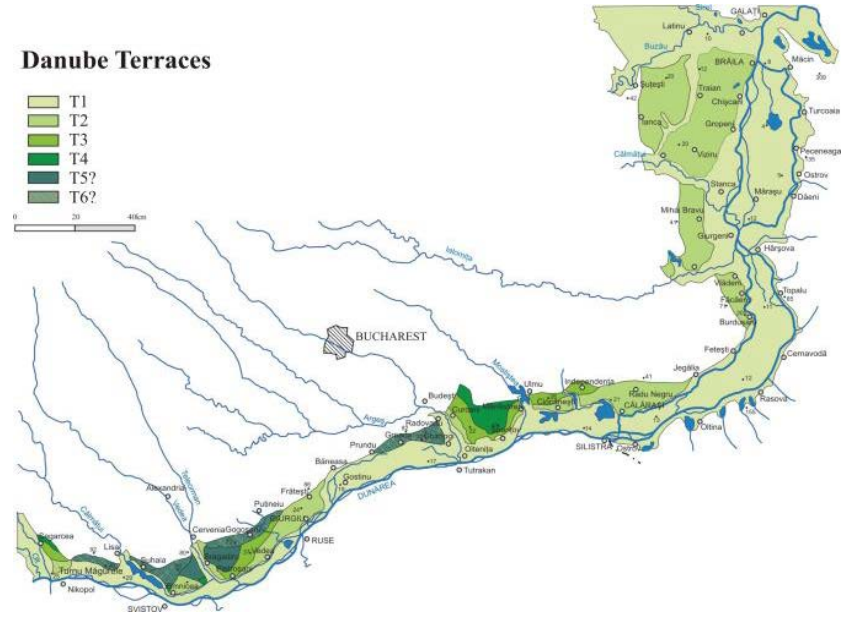

Fig. 5. Danube Terraces downstream of the Olt confluence (after [7])

\section{REFERENCES}

[1] D. Vladev, T. Krastev, S. Stancova N., Chencova, and V. Penerliev, "Natural-geographic potential of north-eastern Bulgaria and its meaning for the cross-border cooperation with Romania”, in Geographical Forum, vol.7, 2008, pp. 233-247.

[2] F. Grecu, L. Zaharia, G. Toroimac, and R. Dobre, "Risque meteohydrologique dans la vallee du Danube roumain. Le cas des inondations d'avril - mai 2006”, XXeme Colloque de L`Associoation Internationale de Climatologie, 3-8 sept. 2007, Tunis-Carthage, 2007, pp. 277-282.

[3] F. Grecu, L. Zaharia, G. Ioana-Toroimac, and I. Armas, "Floods and flash-floods related to river channel dynamics" in vol. M Rădoane, F. Vespremeanu Stroe eds, Landform dynamics and evolution in Romania, Springer Verlag, 2016, pp. 867 - 914.
[4] Ş. Grigorie, Valea Dunării în sectorul Oltenița-Călăraşi. Studiu hidrogeomorfologic, Teza de doctorat, Univ. din București, 2013, unpublished. (in Romanian)

[5] P. Ramez, "Erosion et transport solide en rivière", tome 1, in Guide pour la compréhension des phénomènes CEMAGREF Goupement de Lyon, 1995, p.130.

[6] P. Ramez, A. Paquier, "Morphologie des rivière à gravier pavées avec berges érodables", in La Houille Blanche. Revue internationale de l’eau, CNR, 5/2004, Paris.

[7] Institutul de Geografie, Geografia văii Dunării românești, Editura Academiei, București, 1969, p. 784. (in Romanian) 


\title{
Burial dating of fluvial terraces using cosmogenic nuclides, Arieş River
}

\author{
Maria Hosu \\ Faculty of Geography, \\ Babeş-Bolyai University, \\ Str. Clinicilor Nr. 5-7, 400006, România \\ maria.hosu@ubbcluj.ro
}

\author{
Delia M. Gheorghiu \\ CIAF-NERC, \\ Scottish Universities Environmental Research Centre, \\ East Kilbride, \\ Glasgow, U.K
}

\author{
Sheng $\mathrm{Xu}$ \\ AMS, \\ Scottish Universities Environmental Research Centre, \\ East Kilbride, \\ Glasgow, U.K
}

\begin{abstract}
Dating of the fluvial terraces and providing a morphochronological picture has always been part of a controversial scientific debate, both locally and globally. The rivers in the Transylvanian Basin were studied between 1960 and 1980 and mainly focused on the number of teracces, the timing of river incision and how these terraces are represented in a palaeoreconstruction framework. In most cases, these studies were based on sedimentology, palynology, palaeontology, and archeology, but their chronological history has never been established. Surface exposure dating using the 10Be and $26 \mathrm{Al}$ cosmogenic nuclides would be an ideal dating method; however, river terrace deposits are made of individual clasts, each with their unique complex history of an initial exposure during exhumation and fluvial transport and then burial. This study is based on the numerical dating of the River Arieş terraces in the Corneşti Plăieşti area using the cosmogenic burial dating method. The morphological features of the study area were initially mapped in the field using topographical maps (1:25 000), geological maps (1:50,000), and orthophotographs $(50 \mathrm{~cm}$ resolution). The cosmogenic samples were collected from three different terraces from depths down to 12-15 $\mathrm{m}$ from newly excavated parts within the study area. The 10Be and 26Al burial dating of these river terraces yields palaeoincision rates in the upper basin during the terraces deposition, provides age estimates for these deposits and further argues for the role of climate and tectonics in the deposition and subsequent incision of the terraces.
\end{abstract}

Keywords - fluvial terraces; cosmogenic nuclides; burial dating; Romania; Arieş

\section{INTRODUCTION}

In the River Arieş basin, the terraces have been studied since 1912 [1] when the existence and the extent of terraces steps were firstly discussed, both in a transversal and longitudinal river profile. Subsequent research studies
[2] [3] [4] [5] noted the number of river terraces and their altitudinal distribution, the structure and the hydrogeological observations made on the terraces for determining the level of the water table. Most of these studies were made by geomorphological mapping on certain sectors, with extrapolations for the entire transversal and longitudinal profile of the river.

Our study area is located in the lower sector of the River Arieş (Fig. 1) where six levels of terraces were identified. The size of the terraces differ from one place to another based on the genesis and the morphological and tectonic context of this area. The transversal profile in the lower part of the river is asymmetric.

In this study we present numerical ages obtained from sediment samples taken from several terraces in the study area. Cosmogenic burial dating is a method based on the radioactive decay rates of cosmogenic nuclides. This method requires the sample to be completely shielded after the initial exposure [6]. We employ the burial-dating method to calculate the time since deposition of the terraces, the palaeo-erosion rates in the basin at time of deposition of these terraces, and the rates of erosion since deposition. This study introduces the first application of the cosmogenic burial method to terraces in Romania.

\section{GEOMORPHOLOGY}

The River Arieş drains the following units within its basin: the Bihor Mountains located in the western part of the basin; the Gilău-Muntele Mare Mountains in the central and north-central part; the Metaliferi and Trascău Mountains in the south and south-east and the Feleac Hills in the north-eastern part. 
The Arieş basin spreads over $3005 \mathrm{~km}^{2}$, between 1108 $\mathrm{m}$ and $264 \mathrm{~m}$ altitude, and has a mean altitude of $818 \mathrm{~m}$. The river is $166 \mathrm{~km}$ long and has a mean gradient of 5\% and a sinuosity coefficient of 1.71 [7].

Before exiting the mountain area, the River Arieş cut a deep gorge in limestone and magmatic rocks (Mesozoic magmatites). Downstream of this sector, the morpho hydrographic character of the river changes when flowing through the more friable sedimentary rocks of Miocene age (clays and marls). The influence of petrography caused the River Arieş to create a basin type corridor at the meeting point between the Apuseni Mountains and the Transylvanian Basin, a corridor which becomes larger towards the confluence with the River Mureş. Furthermore, the sudden change of the geological deposits generally explains the slope modifications of the River Arieş: 3.3\%o in the Moldoveneşti-Mihai Viteazu sector; 2.9\%o in the Mihai Viteazu-Turda sector; $1.86 \%$ in Turda-Poiana sector and $0.33 \%$ in Poiana - River Mureş sector [2].

Our study area is mainly focused on the fluvial terraces in the lower sector of the River Aries (Fig. 1). Here the terraces are stepped, and mostly asymmetrical on the right side of the river. The thickness of the alluvial sand and gravel within the structure of the terraces $(7-15 \mathrm{~m})$ is thought to have formed through local subsidence, probably as a result of uplift due to diapirism. This subsidence process associated with the general south-east tilting of the geological strata influenced the monolateral formation of the fluvial terraces and the permanent erosion tendency of the River Arieş on the left side.

According to past research, in the lower sector of the River Aries, the fluvial terraces have various extents and altitudes above river level, depending on their position in the longitudinal profile, which means that the relative altitude of the terraces decreases towards the River Mureş.

Previous research studies identified the following terrace sequence: the floodplain terrace with two levels (2$3 \mathrm{~m}$ and 4-6 m); the 10-12 $\mathrm{m}$ terrace, covered in diluvium, has an inclined surface which makes it difficult to delimit it from the lower terrace; the 20-25 m terrace has a maximum extent downstream and becomes narrower upstream; the 35-40 $\mathrm{m}$ terrace is formed throughout the entire longitudinal profile of the valley; the 50-55 m terrace is the most extended and it is present throughout the entire longitudinal profile of the valley, between the gorge at Buru-Moldovenesti and the confluence with the River Mureş; the 70-75 m terrace was identified on the left part of the river as fragments only [2].

\section{METhODS AND RESUltS}

The fluvial terraces in our study area were identified on topographical maps (1:25 000), and most were later checked in the field. Several methods were used to measure terraces heights.

For the relative altitude we calculated the difference between the absolute altitude of the River Aries bed and the absolute altitude of the terraces level on the same alignment. The altitude of few terraces was directly measured on the topographical map $(1: 25,000)$ and the following terraces were identified: the 4-6 m terrace, downstream of the Corneşti town; the 10-12 m terrace, found to be heavily covered in proluvial deposits; the 35$40 \mathrm{~m}$ terrace is the most extensive terrace having an almost horizontal surface; the 50-55 m terrace, well developed in the Moldoveneşti - Bădeni sector.

Subsequent extensive quarrying of sand and gravel in the Bădeni area (where samples AR03, AR04, AR05, AR06, AR07, 08 were collected) the initial topographic surface was significantly modified at the contact between the 35-40 m terrace and the 50-55 m terrace. Moreover, the surface of the 50-55 terrace was eroded by the tributaries of the River Arieş (the Plăieşti and the Bădeni streams). The transition between these two terraces was identified on orthophotoplans (1:5000, year 2005, $50 \mathrm{~cm}$ resolution, $\pm 1.5 \mathrm{~m}$ precision).

Samples for cosmogenic analysis were collected from profiles previously made by quarrying of sand and gravel (ballast). We collected 2 samples from the 10-12 m terrace, four samples from the $35-40 \mathrm{~m}$ terrace, and two samples from the 50-55 m terrace (Fig. 1). Samples were selected from various depths, down to $15 \mathrm{~m}$ below the surface level.

The processing of the 8 samples was entirely performed at the Cosmogenic Isotope Analysis Facility in SUERC (Scottish Universities Environmental Research Centre) in East Kilbride (Glasgow). Samples were crushed and wet sieved and quartz was separated from the other minerals through various mechanical and chemical processes. Be and $\mathrm{Al}$ were further isolated through column chromatography. The samples were subsequently measured by Accelerator Mass Spectrometry) at SUERC.

The calculated 10Be and 26Al concentrations were modeled using a computer algebra system. This model shows a complex exposure-burial history of these terrace deposits, with periods of initial exposure, transport and burial of sediments and subsequent periods of erosion of these sediments combined with deposition.

The model used in this study provides minimum ages for the deposition of the terraces in the lower sector of the River Arieş (up to $1.7 \mathrm{Ma}$ ). The terraces may well be the result of older reworked alluvial deposits, revealing a complex transportation history from the higher up source area. This is well supported by the variety of erosion rates in the Arieş basin (20-150 m/Ma), also suggesting that tectonics and climate had both an important role in the fluvial processes that occurred in this area.

\section{CONCLUSIONS}

The burial dating model allows to calculate minimum ages of the deposits using paired cosmogenic nuclides and gives an understanding of the sedimentological history at the time of terraces deposition. This method has applicability in various environments for understanding the past climate and tectonics. Our study suggest that the terraces were formed during the Quaternary period and it is a major contribution to a growing dataset for the Carpathians region. 


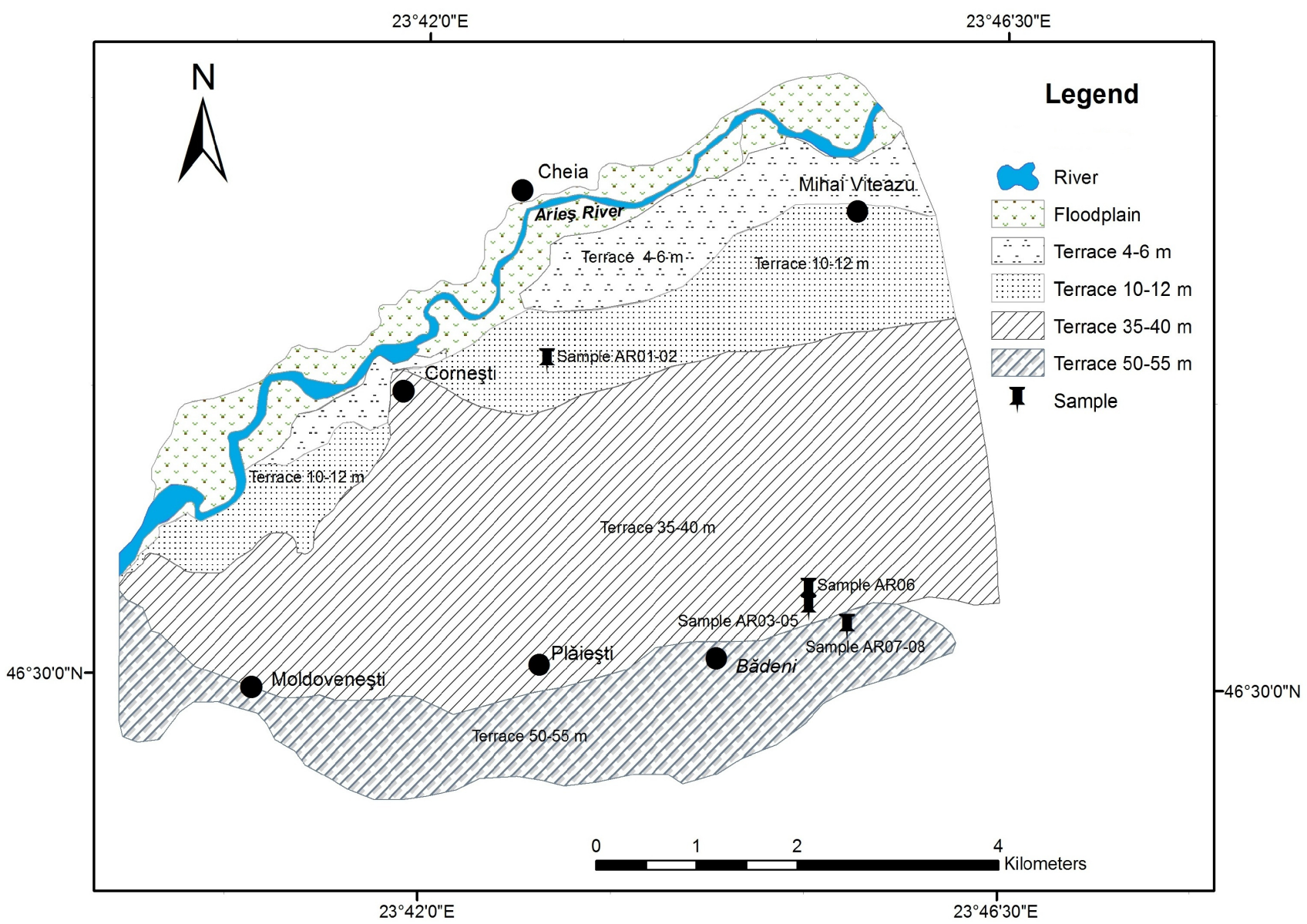

Fig. 1. Study area in the lower sector of the River Arieş. Geomorphological map. Location of samples collected.

\section{ACKNOWLEDGMENT}

The authors are grateful to the Cosmogenic Isotope Analysis Facility and Accelerator Mass Spectrometry Facility at SUERC for the sample preparation and measurement.

\section{REFERENCES}

[1] L. Sawicki, Beitrage zur morphologie Siebenburgen, 1912, manuscris. (in German)

[2] T. Morariu and D. Iacob, "Câteva observații hidrogeologice în bazinul inferior al Arieşului”, Studia Universitatum Victor Babeş et Bolyai, III, 5, seria II, Geologie-Geographia, Cluj-Napoca, 1958. (in Romanian)
[3] T. Morariu and V. Gârbacea, "Terasele râurilor din Translvania”, Comunicări ale Academiei Române, vol. X, nr.6, Bucuresti, 1960. (in Romanian)

[4] Al. Savu, I. Mac, and P. Tudoran, "Aspecte privind geneza şi vârsta teraselor din Transilvania”, in Realizări în geografia României, Culegere de studii, ed. Ştiinţifică. Bucuresti, 1973. (in Romanian)

[5] Gr. Pop, Depresiunea Transilvaniei, Edit. Presa Universitara Clujană, Cluj-Napoca, 2001. (in Romanian)

[6] G. Balco and C.W. Rovey II, "An isochron method for cosmogenic-nuclide dating of buried soils and sediments", American Journal of Science, vol. 308, no. 10, pp. 1083-1114, 2008.

[7] Atlasul Cadastrului Apelor din România, Ministerul Mediului. Partea 1. Date morfo-hidrografice asupra reţelei hidrografice de suprafaţă, Bucureşti, 1992. (in Romanian) 


\section{Sediment dynamics and channel}

\section{adjustments following a torrential flood in a small catchment: Gemenea, Eastern Carpathians}

\author{
Florentina Livarciuc, Maria Rădoane \\ Ștefan cel Mare University of Suceava \\ Suceava, Romania \\ florentina_livarciuc@yahoo.com,radoane@usm.ro
}

\begin{abstract}
Our paper is aimed mainly to analyze temporal behavior of the succession of processes that occurred during the development of an exceptional rainfall in a small catchment. The ultimate purpose of our analysis was to understand the role of the factors that controlled the water and sediment fluxes along the drainage network and how the torrential channels responded in cross-section.
\end{abstract}

Keywords - small watershed; torrential flood; sediment dynamics; geomorphological processes

\section{INTRODUCTION}

Understanding the succession of hydrogeomorphic processes based on direct records at the level of small hydrographic basins still remains an understudied issue. The interest in studying small catchments, defined as fundamental erosional systems [1], was triggered starting with the research performed by [2, 3] and in Romania by $[4,5,6]$. To these authors, the contributions of the forestry or agronomy research must be added $[7,8]$. Each of these authors has highlighted the need for a quantitative approach in the study of processes at the level of elementary catchments, i.e., the need for direct measurements of the processes responsible for landform dynamics. Our paper employs such an approach, and is aimed mainly to analyze temporal behavior of the succession of processes that occurred during the development of an exceptional rainfall in a small catchment. The ultimate purpose of our analysis was to understand the role of the factors that controlled the water and sediment fluxes along the drainage network and how the torrential channels responded in cross-section.

\section{STUdy AREA AND THE DATABASE}

The Gemenea drainage basin $\left(\mathrm{A}=77.7 \mathrm{~km}^{2}\right.$, order $\mathrm{V}$ of magnitude in the Strahler system), located in the northeastern part of the Eastern Carpathians, falls into the category of small catchments. It is characterized by a dense network of stations monitoring hydroclimatic processes, to which we added our measurements on sedimentology and

\author{
Adrian Chelariu Moroșan \\ Water Management System \\ Suceava, Romania \\ chelariu.adriann@yahoo.com
}

torrential channel dynamics (Fig. 1). There are five gauging stations on the main river and its tributaries, which recorded in detail the effects of the rainfall occurred on 27.06.2016 and the formation of a flash flood with all the geomorphological processes it involves.

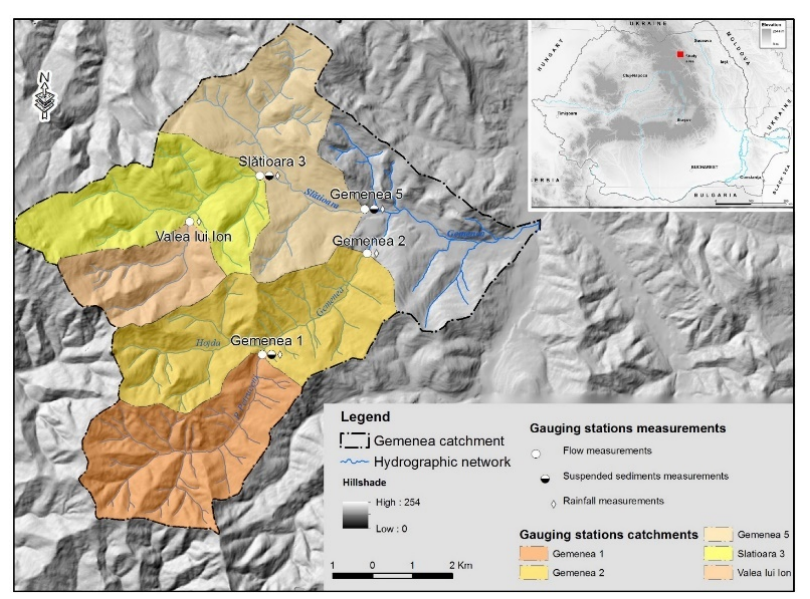

Fig. 1. The Gemenea catchment and the network of gauging and pluviometric stations

The Gemenea River and its tributaries are part of the Moldova River hydrographic system and drain the eastern flank of Rarău Mountains, the northern flank of Stânişoara Mountains respectively. The characteristics of the geological substrate, of the landforms within the subdrainage basins and the percentage of forest cover are presented in Tab. 1 . These characteristics indicate that the five sub-drainage basins belong to the mountain area, the dominant geologic substrate being crystalline rocks or flysch. These are catchments with high potential energy that favors flow and rapid collection of water from precipitation. The configuration of these catchments tends to be of average to high circularity. Forest cover is generally high, except for the Gemenea 2 sub-drainage basin. 
The available database consisted of: 1) daily data for year 2016 on precipitation and water discharges at all five pluviometric and gauging stations considered; 2) daily data on suspended sediment load at the gauging stations Gemenea 1, Slătioara and Gemenea 5 for year 2016; 3) detailed pluviographs and hydrographs on the rainfall and flash flood between 27. 06 and 4.07.2016; 4) data on the dynamics of the cross-section of riverbeds at Gemenea 1 and Gemenea 2 gauging stations. Database processing consisted of statistical analysis (distribution of data sets, histograms, correlation and regression) and construction of synthetic graphs and maps on the spatial and temporal behavior of the analyzed parameters.

TABLE I. MORPHOMETRIC DATA ON THE STUDIED SMALL WATERSHEDS

\begin{tabular}{|c|c|c|c|c|c|c|}
\hline$\underbrace{\text { Watershed }}_{\text {Variable }}$ & Units & Gemenea 1 & Gemenea 2 & Valea lui Ion & Slătioara & Gemenea 5 \\
\hline Area $(\mathrm{A})$ & $\mathrm{km}$ & 13.88 & 30.28 & 6.59 & 6.45 & 19.14 \\
\hline Maximum elevation (Hmax) & $\mathrm{m}$ & 1430.00 & 1430.00 & 1490.00 & 1600.00 & 1600.00 \\
\hline Minimum elevation (Hmin) & $\mathrm{m}$ & 760.00 & 680.00 & 780.00 & 790.00 & 720.00 \\
\hline Average elevation (Hmed) & $\mathrm{m}$ & 1095.00 & 1055.00 & 1135.00 & 1195.00 & 1160.00 \\
\hline Basin perimeter $(\mathrm{P})$ & $\mathrm{km}$ & 17.26 & 25.75 & 10.97 & 10.84 & 18.41 \\
\hline Basin energy (Emax) & $\mathrm{m}$ & 670.00 & 750.00 & 710.00 & 810.00 & 880.00 \\
\hline Average slope (As) & $\%$ & 41.40 & 36.87 & 39.37 & 36.75 & 36.61 \\
\hline Shape coefficient (Sc) & - & 0.45 & 0.40 & 0.44 & 0.45 & 0.57 \\
\hline Basin circularity (C) & - & 0.74 & 0.75 & 0.68 & 0.68 & 0.67 \\
\hline Relief raport (RR) & $\mathrm{m} / \mathrm{km}$ & 108.89 & 78.42 & 165.46 & 190.14 & 134.23 \\
\hline Integral hypsometric (IH) & $\%$ & 0.55 & 0.55 & 0.55 & 0.55 & 0.55 \\
\hline Drainage network length (Ld) & $\mathrm{km}$ & 36.05 & 76.65 & 14.34 & 12.96 & 41.52 \\
\hline Drainage density (Ld/A) & $\mathrm{km} / \mathrm{km}^{2}$ & 2.60 & 2.53 & 2.18 & 2.01 & 2.17 \\
\hline Forest cover $(\mathrm{F})$ & $\%$ & 87.85 & 68.84 & 92.30 & 79.36 & 75.80 \\
\hline Cristalline rocks & $\%$ & 88.0 & 63.7 & 78.2 & 44 & 24.7 \\
\hline Flysch rocks & $\%$ & 3.0 & 30.3 & 22.0 & 56 & 74.7 \\
\hline Quaternary rocks & $\%$ & 9.0 & 6.1 & 0 & 0 & 0.6 \\
\hline Rainfall & $\mathrm{mm}$ & 985 & 862 & 830 & 816 & 836 \\
\hline Water discharge & $\mathrm{m}^{3} / \mathrm{s}$ & 0.204 & 0.574 & 0.0622 & 0.208 & 0.478 \\
\hline Suspended sediment load & $\mathrm{Kg} / \mathrm{s}$ & 0.728 & NA & NA & 0.0118 & 0.241 \\
\hline
\end{tabular}

\section{RESULTS AND DISCUSSIONS}

Monitoring climatic, hydrological and geomorphological processes during the calendar year 2016 enabled the construction of a suite of diagrams showing how the water and sediment flows crossed the catchment until it reached the outlet of river network. We selected for presentation the data recorded for the Gemenea tributary (Sections 1 and 2) (Figs 2 and 3). Furthermore, detailed diagrams were constructed for all five sub-drainage basins.

In 2016, the five sub-drainage basins received rainfall ranging from $985 \mathrm{~mm}$ (Gemenea 1) and $816 \mathrm{~mm}$ (Slătioara). Their distribution during the year (Figs. 2A and 3A) shows a high degree of torrentiality given by the amount of rain fallen in a short period, such as during June. Over a single day (June 27th 2016), $67 \mathrm{~mm}$ of rainfall were received by Gemenea 1 catchment, and $37 \mathrm{~mm}$ by Gemenea 2. In the other sub-drainage basins, rainfall was less than $31 \mathrm{~mm}$ over the same day. The central area of the exceptional rainfall was located in the Gemenea 1 catchment. To assess the response in runoff we detailed the development of the two floods with peaks on the 2nd of June and the 27th of June respectively. The resulting changes in river discharge (gauging station Gemenea 1) did not occur rapidly, and the flash flood peak was delayed by 48 hours after the maximum rainfall peak. Conversely, on June 27th, these changes occurred at a much faster rate, as the flash flood peak $\left(37.9 \mathrm{~m}^{3} / \mathrm{s}\right)$ was recorded 50 minutes after the rainfall maximum.

The response in terms of suspended sediment discharges occurred rather synchronously with the daily water discharges (unfortunately, no hourly measurements were performed on the suspended sediment load). For Gemenea 2, a rapid concentration of water in the two flash floods can be noted, as well as an increase in the duration of both floods.

The peak of the flash flood occurred on June 27th was $86.7 \mathrm{~m}^{3} / \mathrm{s}$ and was reached 20 minutes after it was recorded at Gemenea 1. The other three sub-drainage basins fitted the described pattern, except that the amplitude of variation was lower, due to the lower amount of water entered in these basins.
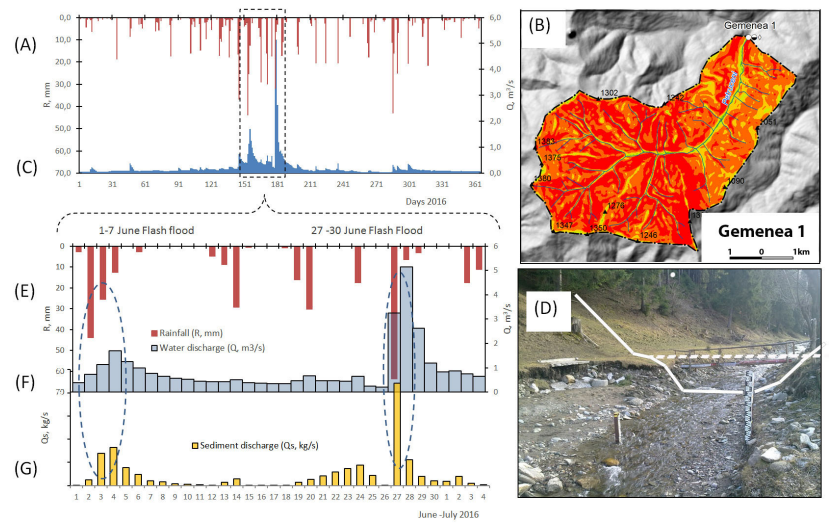

Fig. 2. The succession of hydrodynamic processes in the Gemenea 1 sub-drainage basin: The graphical representation of daily rainfall (A) and water discharge (C) for the year 2016 (in the inset, two flash floods selected for further discussion); (B) The map of the Gemenea 1 sub-drainage basin, with the distribution of slopes; (D) Morphometric characteristics of the catchment; (E) The distribution of precipitation between 1 June and 4 July 2016; (F) The hydrograph of drained water discharge; $(G)$ The hydrograph of the suspended sediments discharge. 
The differences we observed were related to the factors that delayed / accelerated the response of the water and sediment flows, such as the degree of water interception at the surface of the ground by vegetation and litter before June 2nd (higher) and prior to June 27th (lower); higher geodeclivity and circularity of the Gemenea 1 and 2 catchments, which contributed to the increase in propagation velocity of the flow; dominant crystalline rocks in these two catchments, with a thin layer of slope deposits, led to reduced suspended sediment load. Consequently, erosion capacity increased. This latter aspect is illustrated by changes observed for the Gemenea river channel in the two cross-sections shown (Fig. 4).
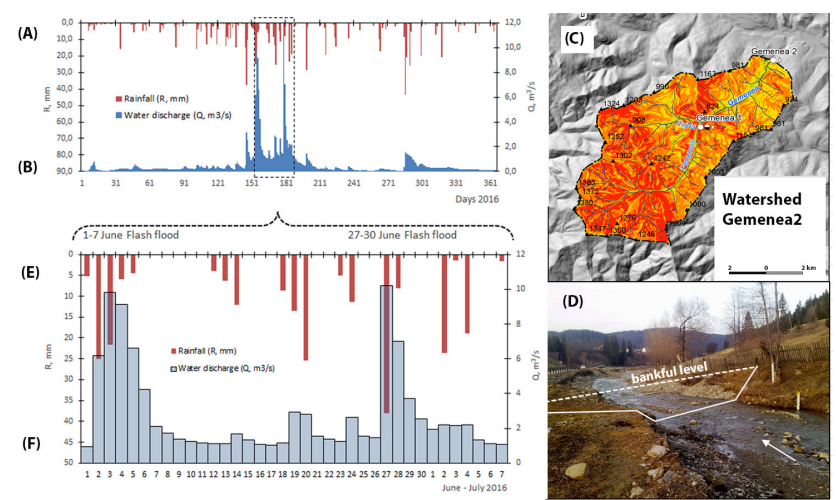

Fig. 3. The succession of hydrodynamic processes in the Gemenea 2 sub-drainage basin (the same explanation as in the caption above).

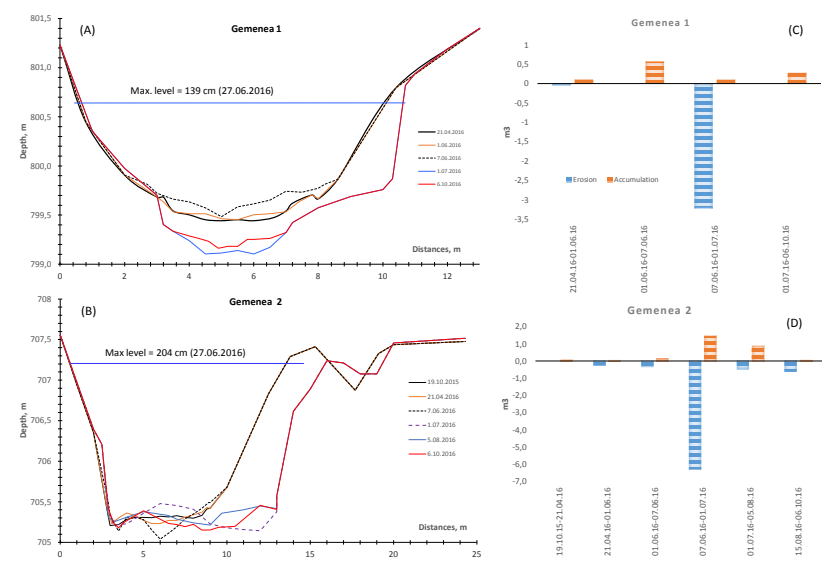

Fig. 4. Response of the Gemenea river channel to flow condition changes during the year 2016: Gemenea 1 (A) and Gemenea 2 (B) cross section dynamics; erosion-accumulation balance for the Gemenea 1 (C) and Gemenea 2 (D) channel cross sections.

In these valley sectors the channel is cut in the alluvial material of a less developed floodplain, consisting predominantly of gravel, boulders and even blocks. At low levels of discharge, channel processes are a quasi-balanced alternation between erosion and accumulation. This alternation was visible only at the channel bottom level. The flash floods from June 2016 oversized the cross section, particularly through lateral erosion. The river banks were the most affected, because the friable rocks (gravel and boulders in a sandy matrix) opposed lower resistance than the channel bottom. The balance between fluvial processes became strongly in favor of erosion that increased four times compared to accumulation. After the flood events, the cross-sections show a pattern of slight recovery with redistributed alluvial material.

\section{CONCLUSIONS}

The final conclusion of this paper, summarized in Fig. 5 , shows that one of the most sensitive controls in the distribution of water and sediment discharges is related to morphometry, namely the size of the catchment. As early as 1957, Anderson [9] described drainage basin area as 'the devils' own variable because of the strong control it exercises on the hydrological, morphometric and topologic attributes of streams. It has been widely used, therefore, as a surrogate for stream discharge where data on the latter are unavailable.
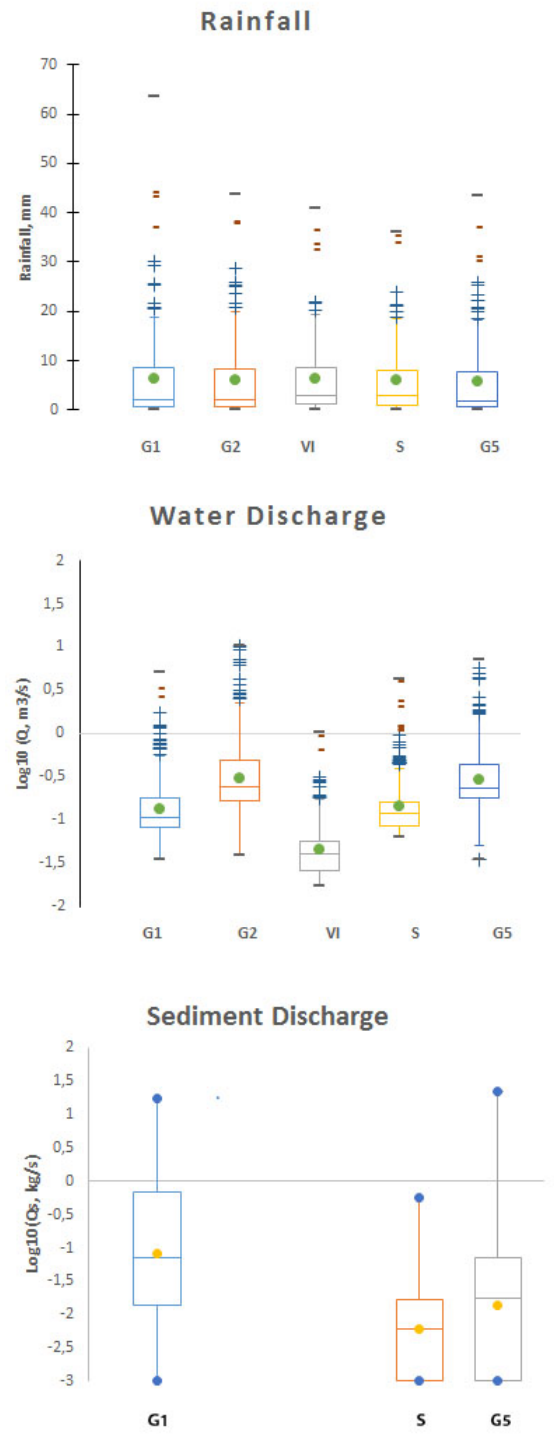

Fig. 5. Distribution of the daily rainfall, water discharge and suspended sediment load values for the five small catchments included in the Gemenea drainage system. The upper and lower limits of the boxes represent the interquartile ranges. The middle lines of the boxes represent the median value of the distribution and the dots show the mean. Whiskers represent one standard deviation, and the small horizontal lines represent all outliers. G1-Gemenea 1; G2 Gemenea 2; VI - Valea lui Ion; S - Slătioara; G5 - Gemenea 5.

Monitoring water and sediment discharge in the five mountain sub-drainage basins, sized between $6.45 \mathrm{~km}^{2}$ and $30.28 \mathrm{~km}^{2}$, showed that the first factor distributing the water volume received from rainfall is catchment size. 
Daily rainfall sum for the year 2016 shows a distribution of mean and median values with no large differences from one catchment to another (Fig. 5, Rainfall). The difference is seen in the outliers (maximum values) describing the nuclei of short duration precipitation, as recorded at Gemenea 1. On the other hand, the amount of water to be drained is reached in a short time depending on the size of the drainage basin. This in fact shows the efficiency in the pattern of water transport to the outlet point of the catchment. The two catchments (G1 and G2), with a dense drainage network, also have better efficiency in water transport (Fig. 5, Water discharges). Regarding the transport of sediments (data were available only for three sub-drainage basins), the highest efficiency characterizes the G1 catchment, despite that the sediment source is a hard rock (predominantly crystalline schists). In what concerns this latter issue, longer term investigations are needed to conclude whether a catchment mainly on crystalline schists provides a greater amount of suspended sediment. Yet this issue remains open in the present analysis.

\section{REFERENCES}

[1] L. B Leopold, M. G.Wolman, and J. P. Miller, Fluvial processes in geomorphology, W. H. Freeman and Company, San Francisco, California, 1964.

[2] R. E. Horton, "Erosional development of streams and their drainage basins: hydrophysical approach to quantitative morphology,” Bull. Geol. Soc. Am, vol. 56, pp. 275-370, 1945.

[3] A.Strahler, "Quantitative Analysis of Watershed Geomorphology,” Transactions, American Geophysical Union, vol. 38, no. 6, pp. 913920, 1957.

[4] I. Zăvoianu, Morfometria bazinelor hidrografice, Ed. Acad. Republicii Socialiste România, 1978. (in Romanian)

[5] I. Ichim, "Cu privire la abordarea holistă a sistemelor geomorfologice fluviale,” Hidrotehnica, t. 23, nr.II, pp. 413 - 418, 1988. (in Romanian)

[6] N. Rădoane, Geomorfologia bazinelor hidrografice mici, Editura Universităţii Suceava, 2002. (in Romanian)

[7] R. Gaspar and E. Untaru, "Cercetări privind scurgerea de suprafață şi transportulde aluviuni în bazine hidrografice mici, torențiale, parțial împădurite,” I.C.A.S., s. II-a, București, 1978. (in Romanian)

[8] M. Moțoc, S. Munteanu, V. Băloiu, P. Stănescu and G. Mihai, "Eroziunea solului și metode de combatere," Ed. Ceres, București, 1975. (in Romanian)

[9] I. Ichim and M. Rădoane, "A multivariate statistical analysis of sediment yield and prediction in Romania,” Geomorphological Models, ed. Fr. Ahnert, Catena Suppl. 10, pp.137 - 146, 1987. 


\title{
Effective development by relief suitability and transport infrastructure of the Obârșia Lotrului ski area
}

\author{
Laurenţiu Ilie, Laura Comănescu, Robert Dobre, Madalina Teodor \\ Geomorphology - Pedology - Geomatics Department \\ Faculty of Geography, University of Bucharest \\ Bucharest, Romania
}

\begin{abstract}
Relief and climatic conditions represent two defining elements for the development of a ski area in a mountain area. The study proposes an evaluation of parameters of particle morphology and morphographic relief, in order to identify the most suitable areas. The analysis of the slope and exposure of the hips, to which we can add the geology and the land cover, needs a high accuracy GIS project. The technical longitudinal profiles of the proposed slopes, represents a good tool for determining the slopes degrees of difficulty. At the same time, the study proposes the validation for the profitability rates of the ski area. The methodology focuses on two main stages. In the first stage, based on the GIS techniques, were identified the sustainability areas for the ski slopes, while in the second stage was conducted if the ski lift infrastructure is enough developed to serve the proposed ski domain.
\end{abstract}

Keywords - GIS; profitability rates; optimization; ski area; geomorphological factors; climatic factors

\section{INTRODUCTION}

The proposed study aims to capture the ideal framework between the ski lift infrastructure and the ski slopes in order to determine the profitability rates of the ski area. Although the study indicate if a second phase of ski lift infrastructure development is necessary.

\section{STUDY AREA}

The area selected for this study represents an "unexplored" one, from the Meridional Carpathians, in this case the Latoritei Mountains of the Parang group of Mountains. The Obârşia Lotrului resort, which will support the ski area, is the perfect support for this development. In addition to these favourable aspects (geomorphological and climatic factors) for the development of Obârşia Lotrului ski resort. Vidra resort which is situated near also indicates the suitability of the area for the development of the ski domain. [1]

The studied surface is approximate 565.0 ha. The area between Mount Miru and Obârşia Lotrului has 103 ha, lying between the North of the Lotru valley and the South of the Latoritei valley.

\section{SCOPE AND OBJECTIVES}

The first part of the methodology used to identify the suitability areas, is based on the technique of raster operations [2]. So they were reclassified in value intervals and resulted following maps: aspects map, geodeclivity map and the hypsometric map (see table of values). Afterwards each raster operations, a map is created. This map was reclassified into three classes of favourability of the snow areas. So the minimum favourability class is defined by the following parameters: lower altitude of 1200 meters, exposed to the south, southeast or southwest and geodeclivity between 5-15 degrees. The medium favourability class is characterized by favourable average altitude of 1200-1600 meters, East or West and geodeclivity between 15-35 degrees. The areas with high favourability are those over 1600 meters altitude, with an exhibition north and a geodeclivity above 35 degrees (geodeclivity above 35 degrees can be assigned for low favourability for winter sports, skiers exercises greater pressure on snow) [3].

TABLE I. TABLE OF VALUES AND THEIR INTERVALS CLASSIFICATION

\begin{tabular}{|c|c|c|c|c|c|c|}
\hline No. & $\begin{array}{c}\text { Asp } \\
\text { ect }\end{array}$ & $\begin{array}{c}\text { Favo } \\
\text { urabi } \\
\text { lity }\end{array}$ & $\begin{array}{l}\text { Geode } \\
\text { clivity }\end{array}$ & $\begin{array}{c}\text { Favour } \\
\text { ability }\end{array}$ & $\begin{array}{c}\text { Altitu } \\
\text { de }\end{array}$ & $\begin{array}{c}\text { Favour } \\
\text { ability }\end{array}$ \\
\hline 1. & $\mathrm{~N}$ & \multirow[b]{2}{*}{ high } & 5-15 & small & $<1200$ & small \\
\hline 2. & N-E & & $15-25$ & \multirow{2}{*}{ average } & $\begin{array}{c}1200- \\
1600\end{array}$ & average \\
\hline 3. & $\mathrm{E}$ & $\begin{array}{c}\text { avera } \\
\text { ge }\end{array}$ & $25-35$ & & $>1600$ & high \\
\hline 4. & S-E & \multirow{3}{*}{ small } & $35-45$ & high & & \\
\hline 5. & $\mathrm{~S}$ & & & & & \\
\hline 6. & S-V & & & & & \\
\hline 7. & V & $\begin{array}{c}\text { avera } \\
\text { ge }\end{array}$ & & & & \\
\hline 8. & $\begin{array}{l}\mathrm{N}- \\
\mathrm{V}\end{array}$ & high & & & & \\
\hline
\end{tabular}


The efficiently development of ski areas is when the length of the ski slopes is greater than 3.5 times the lift installation. By applying this method on existing domains from Romania, we can conclude that we have six domains that exceed the parameter of rentability. In this category falls six ski domains in the country: (Șureanu - 5.14, Snow Parc Ciumani - 4.53, Drumul Tătarilor - 4.27, Buskat Ski\& Summer Resort - 3.6, Borsec - 3.59 and Semenic 3,53). To determine the optimum number of skiers who may find simultaneously themselves on a ski slope was considered that the optimum distance is 12 meters between them. The ski slope areas were divided by a square (144 square meters) to obtain the number of squares covering ski area. To determine the optimum number of skiers who can simultaneously be on a slope, knowing the number of squares covering the surface of the ski area the following formula is applied: $\mathrm{O}=2 \mathrm{P}+2$ where $\mathrm{O}=$ the optimum number of skiers, $\mathrm{P}=$ the numbers of the squares [4].

\section{RESUltS}

To determine the optimal development of the Obârşia Lotrului proposed ski area, we apply the model identified. This may indicate whether the proposed development of cableway infrastructure has a required capacity for the slopes surface designed for an optimum number of skiers. The total area of slopes identified is $2046300 \mathrm{~m}$, which divided by $144 \mathrm{~m}$ and is resulted a total of 14210 square. Applying the formula $\mathrm{O}=2 \mathrm{p}+2$ [4], there is an optimum number 28422 skiers. The total capacity of cableway infrastructure proposed is estimated at 2773 people in 15 minutes, so the estimated maximum hourly capacity is 11 092 skiers per hour.

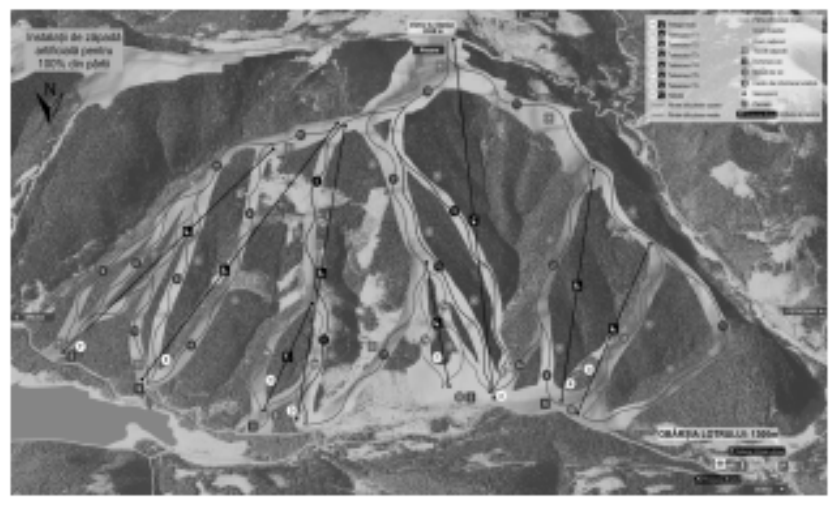

Figure.1 The proposed ski domain - Obârșia Lotrului (panoramic map)

\section{CONCLUSIONS}

By applying the model, we identified an underdevelopment cableway infrastructure which is half the optimum capacity of skiers. This result indicates that in this area is necessary to develop new cableway infrastructure

\section{REFERENCES}

[1] C.A. Tudor, I.C. Ioja, I. Patru-Stupariu, M.R. Nita, and A.M. Hersperger, "How successful is the resolution of land-use conflicts? A comparison of cases from Switzerland and Romania”, Applied Geography, vol. 47, pp. 125-136, 2014.

[2] M. Voiculescu and A. Onaca, "Snow avalanche assessment in the Sinaia ski area (Bucegi Mountains, Southern Carpathians) using the dendrogeomorphology method”, Area, vol. 45, pp. 109-122, 2013.

[3] M. Teodor and R. Dobbre, "Relief Suitability for Developing a Macro Ski Area between Predeal and Azuga Resorts”, Revista de Geomorfologie, vol. 17, pp. 95-106, 2015.

[4] Teodor M, Proiectarea, dezvoltarea și managementul domeniilor schiabile din România, teză de doctorat, 2016. (in Romanian) 


\title{
Geomorphologic regionalising of the Romanian territory in the space-chronologic system context
}

\author{
Octavian Mândruţ \\ The "Vasile Goldiş" Western University of Arad \\ Arad, Romania \\ octavianmandrut@yahoo.com
}

\begin{abstract}
The geomorphologic regionalising of the area attached to our country have evolved in time in relation with the level of knowledge of its relief and substrate. There is regionalising at various levels (from the entire territory to morphosites), a different denomination of the units of relief, but there are also patterns which are considered acceptable.
\end{abstract}

Currently, it is possible to build an improved objective pattern which may consider among others:

- The relatively recent changes of the research of the geologic substrate through the prism of the tectonics of the active (micro) plaques in the area of our country; relief;

- The scalar size of the taxonomic organization of the

- The relative primate of the chronologic/ temporal component;

- The option for a regionalizing pattern between: the typological model (the similitude of the forms of relief), the morpho-chronologic one (temporal synchronisation), the pattern of the foundation structure (the "tectonic" pattern), the model of the composition of relatively homogenous elementary surfaces (“morphographic” model) etc.

Keywords- morpho-chronologic model; extra-Carpathian area; Carpathian area; the taxonomy of the relief

\section{INTRODUCTION}

The spatial-temporal pattern of the regionalisation starts from the establishment of two large geomorphologic area which are significant at meso scale as follows: the extra-Carpathian area (on an old foundation) and the Carpathian area (on an alpine orogeny structure); each field has more structuring regions, uneven as spread, but relatively homogenous as typology and morpho-chronology.

The pattern proposes an order for analysing the regions, such as: for the extra-Carpathian field, starting with the oldest dried reliefs, and for the Carpathian area, starting with the most expressive region. The internal taxonomy comprises certain updated elements and an apparently simplified denomination.
The details and descriptions of the regional units are presented in a recent paper on the topic ("Romania Regional Geomorphology”, 2015).

\section{Models of Regionalisation}

There are more possibilities for approach of the regionalising matter, depending on certain criteria considered as determining or more significant. Two methodological principles of approach can be considered:

- From subordinated units to smaller composing units, until the level of some microsites (this regionalising may comprise a certain number of few levels, starting from relief sphere to the morphosite). This procedure has an accentuated deductive character, resulted from a detailing process;

- From minimal relevant basic areas to the relief sphere as a whole. For the territory of our country, this would be possible from areas of about $1 \mathrm{~km}^{2}$ to the entire territory of our country which results in a succession of inferences with hyphenated inductive character.

For the first methodological option, there are several possibilities of regionalising, such as:

- Based on a predominantly typological criterion (starting from the main groups of genetic types of relief);

- $\quad$ On areas determined by the vector of superficial flow (thus on morpho hydrography pools);

- $\quad$ By combining the typology item with a certain spatial continuity (resulting relatively homogenous areas, based on a certain criterion, but heterogeneous, based on all internal components);

- The introduction of the time vector and of the substrate of the current relief, which induces a typology (and a regionalisation) while making visible the chronologic size (from the oldest substrates and forms of relief, with a quasihorizontal character - platform areas, cratonized, to the orogeny structures); in this context, we 
mention the originality and relative actuality of the evolving pattern built by I. Al. Popescu - Voiteşti [1];

- Granting the predominant part to the substrate, by delimitation of two major types: platform areas (with superposed relief of more recent age) and orogeny areas (the Carpathian system, formed in the alpine orogeny).

I have presented in a more detailed paper [2] the above presented main possibilities of regionalising. The current model considers to building a regionalising which to highlight the primate of the territory age (which is a reflection of the type of structure and foundation), regardless if a relief carrier is at the surface or it is covered by new sedimentary structures.

\section{SUBSTRATE AND RELIEF}

From the analysis of any significant morphostructural map or of the papers and maps rendering also elements of the foundation, it can be noticed that the territory of our country is at the contact between relatively rigid parts (which belong or had been part of the East European platform) and orogeny areas, situated on the edges of the first one, comprising structures of the AlpineCarpathian system.

The geology works [3] start the analysis of the territory with these platform structures by which the orogeny regions are studied and presented. We believe that the current model does not represent a copying of this vision, but it is just an insertion of the relief seniority (and sometimes even of the subjacent area), as element of origin of the regionalising.

In the same time, we mention that the geomorphologic regionalising performed by geographers who, invariably, start from the Oriental Carpathians and end with the Danube Delta, have an internal stereotypy which is hard to be further sustained.

The modern papers highlight a lot on the temporal side in explaining and describing the relief. The image of the foundation of our country relief, performed by geological and geophysical studies [4], [5], [6] highlight a certain situation which allows for framing this area in the general evolution of the terrestrial relief, according to the plate tectonic theory.

As the movement of the tectonic plate is the main drive in forming the ensembles of the relief sphere (and of its internal components), it is absolutely necessary to consider more predominantly and visibly the geo-tectonic component of the relief forming and evolution.

The current vision of the regionalization starts from the premise of the identification of two major areas on the Romanian territory, with significance for the geologic, tectonic and geo-morphologic area of the Europe:

- The platform area, situated in the Eastern continental part of the Europe which is formed by elements of the prior stand of the alpine orogeny; this is part of the South-Western edge of the East European continental platform and worked as a relatively rigid area for a very long timeframe (0.6 billion years), with elevations and descents, followed by sedimentary series on which the current relief attached;

- The orogeny area, belonging to the alpine Europe, generated during the respective orogeny, comprising a mountain system (the Carpathians) tectonically organised in thrust layer with two associated microridges (Transylvanian microridge and the Pannonia one) covered by sedimentary layers, on which the current relief developed.

As the geo-tectonic and geological researches indicate, the Carpathian arc comes from the regeneration of the continental tectonic edge and it looks like successive sheets (different in names and age)

Starting from this general finding, we have to admit that we find ourselves in front of two geo-morphologic domains belonging to these relatively distinct areas, which are in collision. This type of opinion has been issued with almost six decades ago [7].

\section{GEO-MORPHOLOGIC AREAS AND REGIONS}

The extra-Carpathian area has as common item the existence in depth of some Proterozoic and Palaeozoic structures (of platform), organised in few identifiable areas:

- The East European foundation (the Moldavian platform), for a large part of the substrate of the current relief of the Moldavian Plateau, continued to South-West and South with the Scythian Platform edged, at its turn, further by a depression area (the Barlad Depression); a sedimentation and drying process occurred on this subjacent structure during the Cretaceous - Pliocene interval, with the formation of the current relief;

- The Moesian Platform, located in the foundation of the Romanian Plain, is a structure comprising in its depth rocks alike to the Carpathian-Balkan system; in its Eastern part, the Moesian platform and the South Dobrogea Platform (forming together a microplate) descend in a inclined plan in front of the Sub Carpathians and of the Carpathians of Curvature causing the earthquakes in the Vrancea area and the area of tectonic and subsidence descent from the exterior of the Sub Carpathians of Curvature; the relief of the Romanian Plain foundation is very complex and interesting considering the evolution [8]

- The Dobrogea foundation occurs at the surface in the system of green shale structures which form the oldest relief placed at the surface;

- The North Dobrogea orogeny is currently a cratonized region, though, it represented in the past an area of sedimentation and folding located between the Moldavian Platform (situated in the North) and the Moesian Platform (situated to the South); being comprised between the platform areas, the North Dobrogea orogeny has currently the function of rigid geo-morphologic substrate;

- Currently, there is a descending area between the foundation of the Moldavian Plateau (the EastEuropean Platform) and the Dobrogea - Moesian foundation, named the Pre Dobrogea Depression 
or the Barlad Depression; its existence reflects indirectly in the current relief.

The Carpathian area comprises the Carpathian orogeny and the internal depressions (which superpose to the Transylvanian and Pannonia micro-plate).

This area comprises the following large divisions:

- The Oriental Carpathians (Northern and Central parts), with the three partial structures;

- The Carpathians of Curvature, almost predominantly formed by flysch, with individualised geological structure, relief and functionality in the mountain range;

- The Southern Carpathians (including the Carpathians of the Banat and the Mehedinti Plateau, by the geological structure, and also by position, links, and forms of relief), formed by crystalline schist, granite intrusions, thrust structure and patches of Mesozoic sedimentation;

- Northern Apuseni, a genuine erected part between the two lowered microplates (Pannonia and Transylvanian);
Southern Apuseni (a geosyncline structure) formed by volcanic rocks and flysch;

- The Transylvanian Depression, developed over the Transylvanian microplate, sedimented in long time (Cretaceous - Pliocene), with a relief reflecting the way of arrangement of the rocks of the sedimentary substrate (but less the relief of the foundation); this microplate forms a descended area of the Carpathian crystalline; it looks like an interior depression, and, considering the relief, as an extended sediment intra-Carpathian depression with hillside relief;

- The Western Hills and the Western Plain represent an association of slightly sloped or horizontal shapes, developed on a lowered foundation of the Pannonia microplate; the Transylvanian and the Pannonia microplates are in contact in the proximity of the Meses-Preluca intra-Carpathian yoke;

- Obviously, the Sub Carpathians represent "the last orogeny episode” in forming the Carpathian range, having a much more complex character in continuing the Carpathians of Curvature; the Sub Carpathians follow in a very general way the periCarpathian fault line.

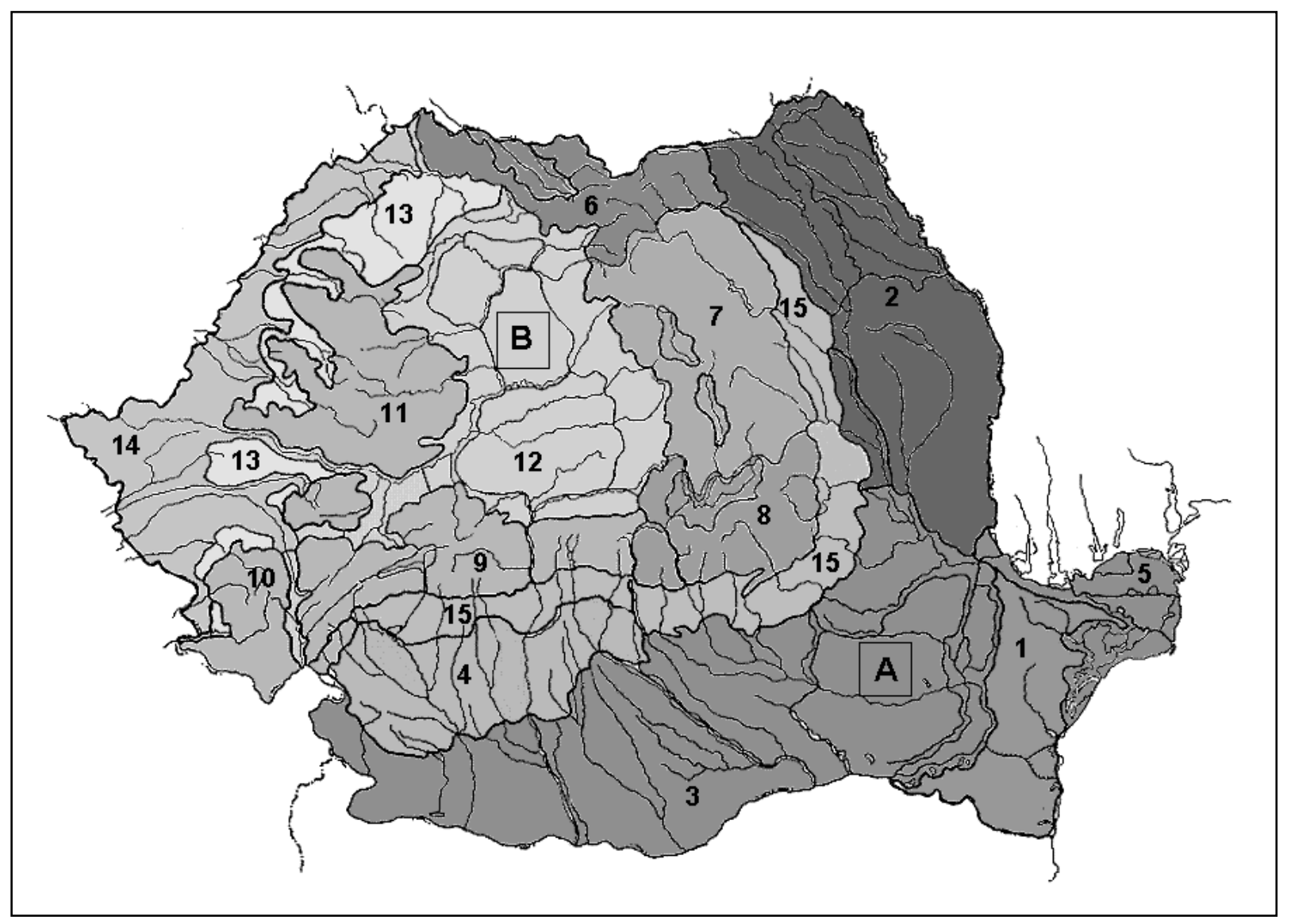

Fig. 1. The Major Geo-Morphologic Area (A, B) and the Component Regions (1 - 15). 
A. The extra-Carpathian area - on rigid, lowered structures covered by sediments and predominantly horizontal relief; it comprises several regions, such as:

1. The Dobrogea Plateau - on the structure of the Central and South Dobrogea Platform and the NorthDobrogea orogeny with a lowered area (the east side of the Romanian Plain)

2. The Moldavian Plateau - predominant on the structure of the Moldavian Platform

3. The Romanian Plain (Centre and West) - on the structure of the Moesian Platform

5. The Danube Delta - on the structure of the preDobrogea Depression

B. The Carpathian area - on the Carpathian orogeny, including the interior microplates with the component regions:

6. The Maramures and Bukovina Carpathians - with three areas and trans-Carpathian flysch

7. The Moldavian-Transylvanian Carpathians - with three parallel areas

8. The Carpathians of Curvature - on an almost exclusively flysch structure

9. The Southern Carpathians - on an alpine orogeny structure and thrust sheets

10. The Banat Carpathians - on the same structure with the Southern Carpathians

11. The Western Romanian Carpathians - on a predominantly crystalline structure (Northern Apuseni), and composite rift one (Southern Apuseni)

12. The Hillside Depression of Transylvania - on the structure of the Transylvanian micro-plate

\section{The Western Hills}

14. The Western Plain - especially on the structure of the Pannonia micro-plate

C. The transition zone (without being an area) comprises the Sub Carpathians (15), with aspects of incipient orogeny, and the Get Piedmont (4), on a mixt structure; this area masks the peri-Carpathian "fault line".

The presentation of the two areas (A and B) represents much more than a simple collation.

The geographers' geo-morphologic regionalising [9], [10], [11], [12], [13], [14] details a lot the regional image.

There are territorial units of smaller area inside each region $(1-15)$. Their names are different (by different authors) and there are references to very small areas with names without obvious justification. We have renounced to some denominative [2] mentions for these units as they would overcharge with local examples an already extended taxonomy.

Each region $(1-15)$ is presented by a unitary structure comprising: the geo-morphological specificity (position, extension, identity, genesis), the geomorphological characterisation (substrate, evolution, morphography, morphometric, morphological structure, types of relief), the internal divisions.

\section{REFERENCES}

[1] I. Popescu Voiteşti, Evoluţia geologico - paleogeografică a pământului românesc, Cluj - Napoca: Institutul de Arte Grafice „Ardealul”, 1936. (in Romanian)

[2] O. Mândrut, România - Geomorfologie regională, Arad: Ed. Univ. Vasile Goldiş”, 2015. (in Romanian)

[3] V. Mutihac and G. Mutihac, Geologia României, Bucharest: EDP, 2010. (in Romanian)

[4] Șt. Airinei, Radiografia geofizică a subsolului României, Bucharest: Editura Ştiinţifică şi Enciclopedică, 1980. (in Romanian)

[5] R. Botezatu, Modele geofizice ale alcătuirii geologice a României, Bucharest: Editura Academiei, 1982. (in Romanian)

[6] M. Săndulescu, Geotectonica României, Bucharest: Editura Tehnică, 1984. (in Romanian)

[7] P. Coteț and C. Martiniuc, „Geomorfologia” în Monografia geografică a R.P.R., vol. I., Bucureşti: Editura Ştiinţifică, 1960. (in Romanian)

[8] D. Paraschiv, „Suprafaţa de denudare înhumată premesogeană (relieful cadomian) la exteriorul Carpaţilor Româneşti”, în Studii şi Cercetări de Geografie, Tom XLVII - XLVIII, 2000 - 2001, Bucharest: Editura Academiei Române, 2001. (in Romanian)

[9] V. Mihăilescu, „Marile regiuni morfologice ale Românei”, în BSRRG, vol. L, 1931. (in Romanian)

[10] P. Coteţ, Geomorfologia României, Bucureşti: Editura Tehnică, 1973. (in Romanian)

[11] Gr. Posea, Geomorfologia României, Bucureşti: Editura Fundaţiei „România de Mâine”, 2003. (in Romanian)

[12] L. Badea, (coord.), Unităţile de relief ale României, vol. I - V, Bucharest: Editura Ars Docendi, 2001 - 2015. (in Romanian)

[13] Gr., Posea and L. Badea, ,Regionarea geomorfologică a teritoriului României”, în Buletinul Societăţii de Stiințe Geografice, serie nouă, vol. VI (LXXVI), Bucureşti, 1982. (in Romanian)

[14] Al. Roșu and D. Bălteanu, „Caracterizarea cantitativă și clasificarea unităţilor geomorfologice din România pe baza varietăţii reliefului”, în Terra, I (XXI), 1, București, 1969. (in Romanian) 


\section{The use of satellite images in the morphological analysis of the Siret riverbed between Cosmești and Galați}

\author{
Diana Alexandra Marola \\ Doctoral School "Simion Mehedinți" \\ Faculty of Geography, University of Bucharest \\ Bucharest, Romania \\ dianaalexandramarola@gmail.com
}

\begin{abstract}
The objective of this work consists in identifying the changes produced in the Siret River, using satellite images.

The study area is represented by a sector of the Siret Plain, heavily influenced by the dynamics of the Siret River reflected in morphology, landscape features, land use, and anthropogenic elements.
\end{abstract}

The working methodology consisted in combining the techniques of remote sensing and GIS in the processing of satellite images Landsat 7 ETM and OLI L8 from 2003 and 2016, aiming the classification of this images according to a few categories of land use in order to observe the dynamics of their distribution in space and time. The main categories of use of land on which we have focused the analysis are located in close proximity to bodies of water. To process images in different spectral bands combinations and vector analysis, we used ArcGis application and related modules.

The results of the analysis of satellite images based on processing, are represented by small differences identified between the categories of land use in the proximityy of the Siret River within the area studied, between the years of 2003-2016.

Keywords_-GIS; satellite images; land use

\section{INTRODUCTION}

This project aims to use satellite imagery for obtaining advanced information related to changes of the relief, geographical elements, and changes of function of the landscape.

The area of study is a low plain area, influenced, in particular, by the dynamics of its main element, the Siret River Valley. The Siret River Dynamics has a major influence on the characteristics of landscape and anthropogenic elements.

\author{
Laura Comănescu \\ Department of Geomorphology, Pedology - Geomatics \\ Faculty of Geography, University of Bucharest \\ Bucharest, Romania
}

\section{AREA OF STUDY}

The studied area is located between Cosmești (North) and Galați Municipality (South) and is located at the contact of the four counties, namely: Vrancea County (Northwest), Galați County (North and East), Brăila (South) and Buzău (Southwest). The position of the area studied is apparent in the following figure:

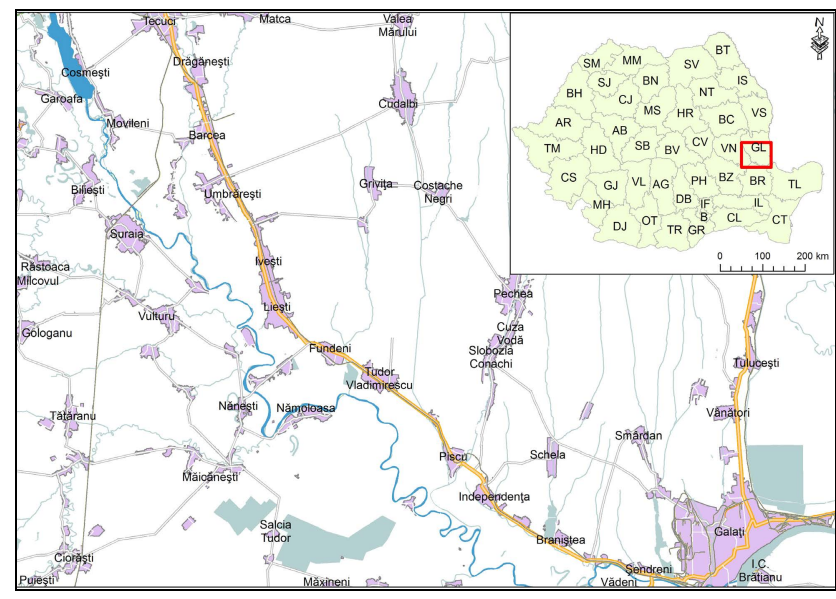

Fig. 1. The location of the studied area

\section{DATA AND METHODOLOGY}

The methodology used for the analysis was based on the identification of several categories of land use on both satellite images, in order to observe the dynamics of their distributions in space and time. The processing software used to analyze the images and to extract the relevant information, were SNAP and ArcGis.

There were used only those combinations of bands which were considered more relevant in accentuating the relevant information for this study. Also, it was used a certain type of pixel classification to represent the distribution of the categories of land use establish. 
Basically, there were obtained certain classifications of pixels, which represent operations based on mathematical algorithms, obtained in digital environment, in order to group pixels with different spectral signature from an image or to group those pixels for which it is known their signification in the field.

Within this phase, it could have been used either an unsupervised classification or a supervised classification. An unsupervised classification means that the value of the pixel it is not known, and involves a differentiation of pixels depending on the spectral signature. For this study, it was chosen the supervised classification which is based on the fact that the analyst knows the significance on the field of the spectral signature corresponding to the pixels in the image.

Before the classification itself, there were chosen a series of groups of pixels with known meaning, as homogeneous in terms of spectral signatures depending on which all pixels in the image will be grouped into categories. This groups shall be called test areas or regions of interest. The same areas of interest have been selected in both images processed, in order to have a correct development of the dynamics of their distribution.

The regions of interest for this study were:

- Water bodies;

- Silt;

- Forests;

- Areas of transition with shrubs;

- Pasture;

- Vineyards;

- Human settlements;

- Agricultural land.

The next step was the actual realization of the classification on the imagery chosen, stage which involves running some mathematical algorithms centered on the test areas for comparison and analysis of the pixels in order to group them in different classes. There are several types of classifications supervised, but the method chosen was a Maximum Likelihood Classification that uses the principle that each cell chosen from each class is distributed normally. So, for each satellite image, it was used a certain combination of bands, the areas of interest were chosen and the supervised classification of the image has been carried out using the specified method.

Subsequently, it was extracted a range of statistical information from previously completed transactions, representing practically the main purpose of this study.

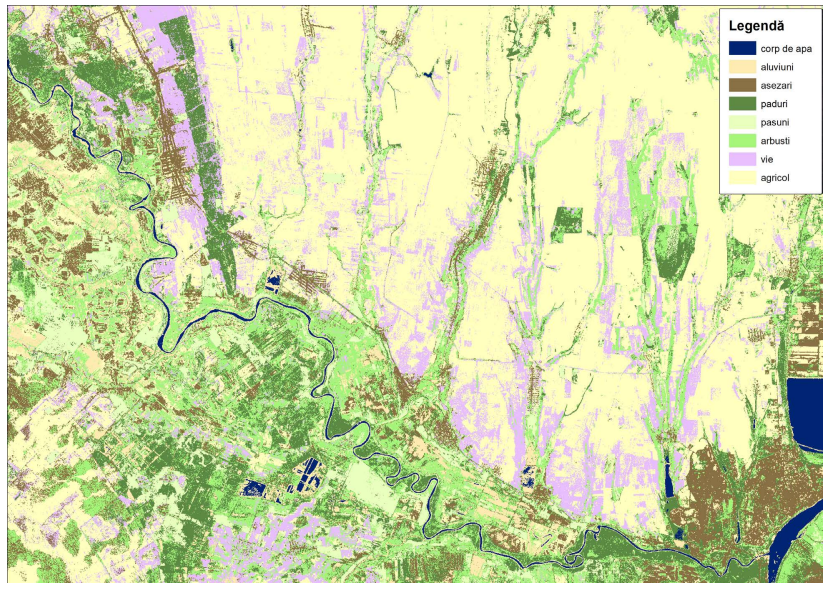

Fig. 2. Maximum Likelihood Classification

\section{RESULTS}

The results of the analysis of satellite images based on processing, are represented by small differences identified between the categories of land use in the proximity of the Siret River within the area studied, between the years of 2003-2016.

\section{REFERENCES}

[1] B. Mihai, Aplicaţii ale aerofotogramelor la scară mare în cercetarea impactului antropic în spaţiul montan, A XXVII-a Sesiunde de comunicări ştiinţifice cu participare internaţională, Ed. Academiei Tehnice Militare, Bucureşti, 1997. (in Romanian)

[2] Agenţia Europeană de Mediu, Corine Land Cover 2006 seamless vector data - version 13 (02/2010), [Available online] | URL: http://www.eea.europa.eu/data-and-

maps/data\#c12=corine + land + cover+version +13 , data accesării: 19.04.2011, ora 12.52 .

[3] Earth Resources Observations and Sience Center (EROS), USGS Glabal Visualisation Viewer, [Available online] |URL: http:/glovis.usgs.gov/AboutBrowse.shtml, data accesării: 7.11.2010 ora 13.23, 21.05.2011 ora 12.30.

[4] V. Crăciunescu, România: seturi de date vectoriale generale, [Available online] | URL: http://earth.unibuc.ro/download/romaniaseturi-vectoriale, data accesării: 19.04.2011, ora 13.55.

[5] Global Land Cover Facility, Earth Sienece Data Interface, [Available online] | URL: http://glcfapp.glcf.umd.edu:8080/esdi/index.jsp, data accesării: 15.04.2010, ora 15.25 , 23.05.2011, ora 22.36 - imagini satelitare Landsat ETM+.

[6] Shuttle Radar Topography - The Mision to Map the World, Imagini SRTM [Available online] | URL: http://dds.cr.usgs.gov/srtm/, data accesărtii: 13.03.2009, 24.04.2011.

[7] ***, Understending GIS. The Arc/INFO Method, ESRI, Regland, USA, 1996. 


\title{
Dendrogeomorphogical assessment of snow avalanche activity in Parâng Mountains
}

\author{
Flaviu Meseșan, Olimpiu Pop, Ionela Gavrilă, Cosmin Timofte \\ Babeș Bolyai University, Faculty of Geography \\ Laboratory of Dendrochronology \\ Cluj-Napoca, Romania
}

\begin{abstract}
In the alpine area of the Romanian Carpathians in general and Parâng Mountains in particular, snow avalanches play an important role in the landscape and ecosystems dynamics. When the snow masses reach the treeline, they are stopped by forests and cause severe disturbances or even death to the trees. If snow avalanches affect repeatedly the same forest area, an avalanche path takes shape. Inside it, the snow avalanche activity is clearly witnessed by forest vegetation. The trees record in their rings signs of past avalanche activity. In particular forest areas, these are the only avalanche event records that can be investigated in order to improve the knowledge regarding past avalanches. Dendrogeomorphology proved to be the most reliable tool for this scope, allowing yearly reconstructions of avalanche frequency and spatial extension. The present study aims to accomplish tree ring reconstruction of snow avalanche in two avalanche paths located on the southern slope of Parâng Mountains, in the proximity of Păpușa Peak (2135 $\mathrm{m}$ a.s.l.), one facing southwest and the other facing southeast. The first mentioned avalanche path is crossed by Transalpina road. Rânca ski resort is placed on a convex slope between these avalanche paths. In the southwestern path, 58 Norway spruces (Picea abies (L.) Karst.) showing severe disturbances caused by snow avalanches were sampled. In the southeastern path, other 52 spruces were sampled. Based on the sampled trees growth disturbances (e.g. scars, tangential rows of traumatic resin ducts, compression wood, growth suppression), the avalanche event chronology was developed for each avalanche path. Then, using a new GIS-based approach, the snow avalanche frequency and return periods were calculated and mapped. The results of this study can contribute to avalanche hazard mapping in the study area and should prevent freeride skiers regarding the snow avalanche risk on southern slopes of Păpușa Peak.
\end{abstract}

Keywords- snow avalanche; Parâng Mountains; denndrogeomorphology

\section{INTRODUCTION}

In the alpine areas of the Carpathians, the snow avalanches are common geomorphic processes. Along occasional damage caused to existing infrastructure (roads, sky areas, buildings, hiking trails, etc.) this processes cause also loss of human lives.

During their descent, the snow avalanches are channeled by topographic features like gullies or valleys until they pass the treeline, causing a significant damage upon forest areas. Repeated avalanche events, even with yearly frequency, may affect the same forest areas. In this case, the forest cannot recover to the state before the event until subsequent event occurs and produces additional damage.

A stripe without mature trees takes shape in the mature forest, downslope from the treeline. In few years, this area is colonized by young coniferous trees or shrubs. The avalanche path includes this stripe but also the starting zone located above treeline and the track placed partially above treeline, partially below it.

The young trees located inside the avalanche path, but also some of the mature trees from the border of the path usually present visible growth disturbances related to the mechanical impact of the avalanches: scars, titled stems, broken tops, broken branches. Based on these, the year(s) when the impact occurred can be identified using geomorphic methods. Such reconstructions of snow avalanche activity were successfully performed in the western part of Parâng Mountains [1], in Făgăraș Mountains [2], in Alps Mountains [3] and other mountain areas worlwide.

In the Romanian Carpathians, the snow avalanche activity is poorly documented. Usually, the recorded avalanche events are the most severe ones, that damaged significant forest areas. In this cases, cleaning up the affected areas was required in order to protect the living trees from fungal infections or from insect outbreaks and also to use the timber from the broken trees.

The avalanche triggering risk in the proximity of Păpușa Peak is confirmed by Cătălina Săndulache in her $\mathrm{PhD}$ thesis [4]. A fatality occured because of snow avalanches near Păpușa Peak is mentioned. The occurence year is not mentioned.

\section{STUDY AREA}

The study area for the present paper consists in two avalanche paths located in the proximity of Păpușa Peak, in the central part of Parâng Mountains, belonging to Southern Carpathians, Romania (fig. 1). One of the avalanche paths is located on the southwestern slope of Păpuşa peak, in a valley called Romanul. 


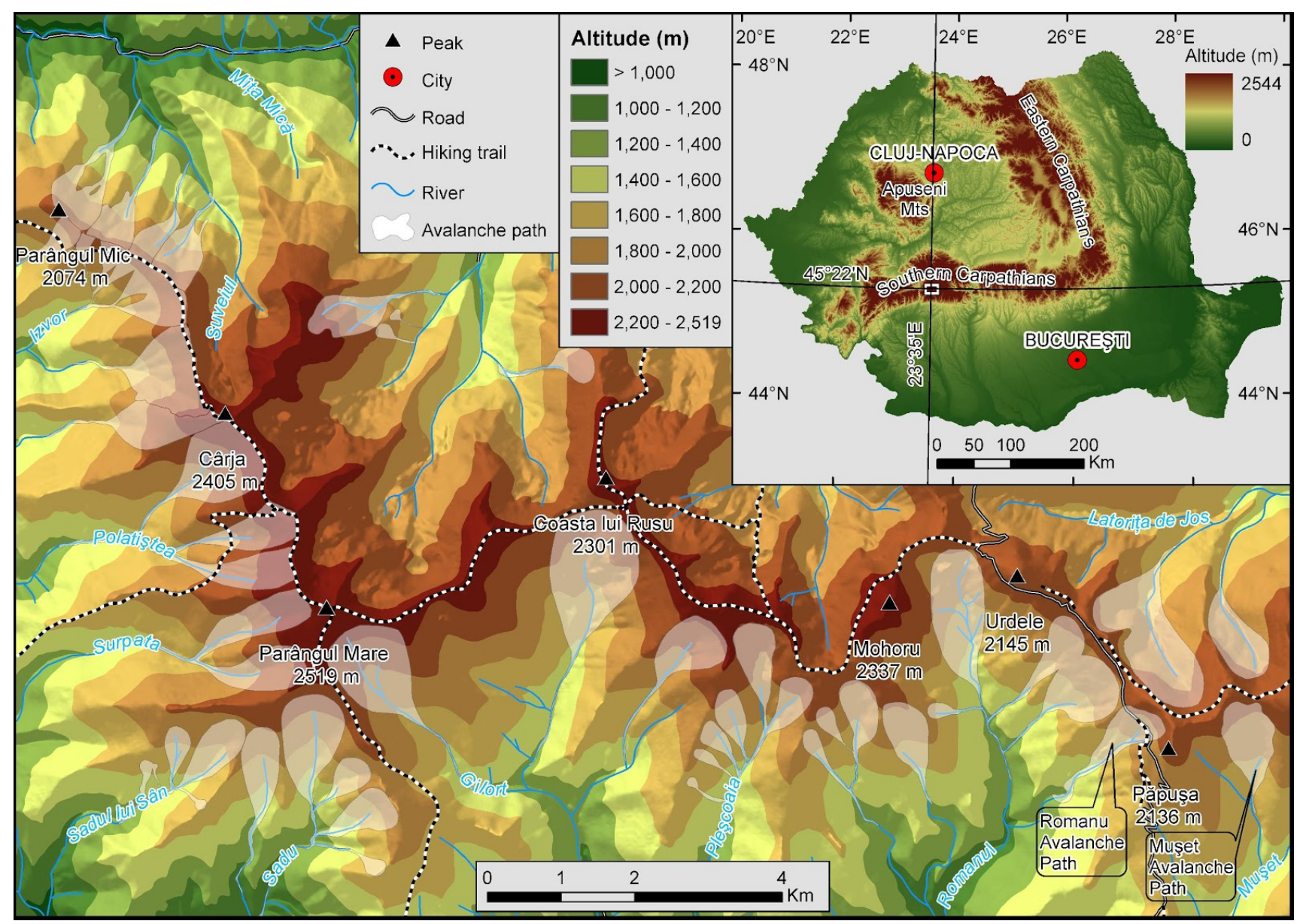

Fig. 1. Study area location.

The start zone reaches the altitude of $2100 \mathrm{~m}$ a.s.l. and the runout zone descends below $1400 \mathrm{~m}$ a.s.l. In the track zone, the valley is deep and the slopes are very steep, especially the western slope. Because of this, the avalanche path can be classified as a typically confined avalanche path. The bottom of the valley and the eastern slope are populated by shrubs and small coniferous trees. The surface of the path is approximately $0.5 \mathrm{~km}^{2}$ and its maximum length is around $1.7 \mathrm{~km}$. In the starting zone, the avalanche path is crossed by Transalpina road. Its status is still road in construction. No avalanche protection technical measures were implemented to protect it from snow avalanches. Excepting the segment from Novaci to Rânca (below $1900 \mathrm{~m}$ at the south of this path), the road is closed during the winter season.

The second avalanche path is located at the east of Păpușa Peak, in the superior basin of a valley called Mușet. It originates at the south of the main ridge, in an incipient glacial cirque, around $2100 \mathrm{~m}$ a.s.l. The runout zone is placed below $1700 \mathrm{~m}$ a.s.l., where the slope is less steep. Around this altitude the snow masses reach the treeline. A quite compact group containing trees with various ages, was affected repeatedly by snow avalanches. The surface of this path is also approximately $0.5 \mathrm{~km}^{2}$, but it has a rounder shape compared with the previous one, with a maximum length around $1.3 \mathrm{~km}$.

\section{METHODS}

The working phases covered in this study followed the classical approaches performed in tree-ring reconstruction of avalanche activity: tree sampling, samples preparing and analyzing, snow avalanche reconstruction. [3, 5].

In the field, the trees shoving severe growth disturbances associated with avalanche activity were sampled using Pressler borers or a saw. In Romanul valley avalanche path, 105 increment cores and 23 cross sections were gathered from 58 trees. In Muşet valley avalanche path, 37 increment cores and 38 cross sections were gathered from 57 trees. The increment cores were glued on spruce slats and air dried along with cross sections. Then all of them were finely sanded.

The width of the tree rings was measured using a strere omicroscope with a moving table (LINTAB 5 workstation) connected to a computer with TSAPWin Professional 0.55 software. The growth anomalies were noted in a Microsoft Excel table and semiautomatically centralized. For every year when multiple growth disturbances were recorded, an index value was calcultated according to [6]. The avalanche event years were established according to the criteria sugested by [7]. As an additional criterion to consider a year as avalanche event year, the value of Shroder's index must be higher than $10 \%$.

A point shapefile representing the location of the sampled trees was created for every avalanche path from the GPS points collected in the field. For every reconstructed avalanche event, the points were classified in disturbed trees for trees presenting growth distubances related to the avalanche event and undisturbed trees for the rest of the points. These data were used to map the spatial extension of every avalanche year. Further usage was to 
calculate the number of the avalanche events that affected every point of the avalanche path.

\section{RESULTS}

The analysis of the collected samples revealed 11 avalanche event years in Romanul valley avalanche path. At leat one of the sampled trees presented a scar in each of this years. Without taking into consideration the 1895 avalanche event, 10 avalanche events took place in 27 years.

Significant differences can be observed between the spatial extension of various avalanches. Some of them affected the entire avalanche path (for example the avalanche occurred in 2004-2005 winter). Other avalanches affected only the sampled trees located near the treeline (like the avalanche occurred in 1997-1998 winter).

In the Mușet valley avalanche path, 10 avalanche events were identified. The length of the avalanche chronology reconstructed in this avalanche path is 41 years.

Because all the sampled trees are grouped in the runout zone of the avalanche path, it was not possible to identify many sectors of the path affected by a different number of avalanche events. Almost the entire path affected by all the reconstructed avalanches.

\section{CONCLUSIONS}

The snow avalanche activity reconstructed in both avalanche path confirms that in this area snow avalanches constitutes a significant risk that must be taken into consideration when planning the infrastructure development or the routes for free ride skiing.

\section{REFERENCES}

[1] O. T. Pop, I. G. Gavrilă, G. Roșian, F. Meseșan, A. Decaulne, I. H. Holobâcă, and T. Anghel, "A century-long snow avalanche chronology reconstructed from tree-rings in Parâng Mountains (Southern Carpathians, Romania).," Quaternary International, vol. 415, pp. 230-240, 2016.

[2] P. Chiroiu, M. Stoffel, A. Onaca, and P. Urdea, "Testing dendrogeomorphic approaches and thresholds to reconstruct snow avalanche activity in the Făgăraş Mountains (Romanian Carpathians)," Quaternary Geochronology, vol. 27, pp. 1-10, 2015.

[3] C. Corona, G. Rovéra, J. Lopez Saez, M. Stoffel, and P. Perfettini, "Spatio-temporal reconstruction of snow avalanche activity using tree rings: Pierres Jean Jeanne avalanche talus, Massif de l'Oisans, France," Catena, vol. 83, no. 2, pp. 107-118, 2010.

[4] C. Săndulache, "Hazarde și riscuri naturale în Munții Parâng", București: PhD Thesis, Universitatea din București, 2009.

[5] M. Stoffel, D. R. Butler, and C. Corona, "Mass movements and tree rings: A guide to dendrogeomorphic field sampling and dating," Geomorphology, vol. 200, pp. 106-120, 2013.

[6] J. F. Shroder, "Dendrogeomorphological analysis of mass movement on Table Cliffs Plateau, Utah," Quaternary Research, vol. 9, no. 2, pp. 168-185, 1978.

[7] M. Stoffel and C. Corona, "Dendroecological dating of geomorphic disturbance in trees," Tree-Ring Research, vol. 70, no. 1, pp. 3-20, 2014. 


\section{Certain and potential earthquake-induced landslides in Vrancea seismic region}

\author{
Mihai Micu \\ Institute of Geography \\ Romanian Academy \\ Bucharest, Romania \\ mikkutu@yahoo.com
}

\author{
Hans-Balder Havenith \\ Department of Geology - Georisks and Environment \\ University of Liege \\ Liege, Belgium \\ HB.Havenith@ulg.ac.be
}

\author{
Dan Bălteanu \\ Institute of Geography \\ Romanian Academy \\ Bucharest, Romania \\ igar@geoinst.ro
}

\begin{abstract}
Earthquakes are representing across Earth's seismically-active regions a major trigger of small-to-large size landslides. Occurred in form of coseismic or postseismic failures, these processes are controlling the slope denudation, inducing in the mean time significant impacts on fluvial morphology through intense slope-channel coupling. Relict, dormant or active forms resembling like earthquake-induced ones are numerous in the Vrancea seismic region (Curvature sector of the South-Eastern Carpathians), at least from a morphological point of view. The purpose of this paper is to outline the morphogenetic framework of such high magnitude and low frequency processes on the basis of several case-studies. The Slon, Zăbala, Zâmbroaia and Mlăjet landslides are known as being triggered by the 1940 and 1977 earthquakes. Two other landslides are showing a very high potential of being as well caused (immediate or delayed) by earthquakes: the deep-seated Balta rock slump (92 ha, 60-80 m thick), a potential co-seismic landslide and the Paltineni debris flow ( $22 \mathrm{ha}, 30-40 \mathrm{~m}$ thick), highly likely the result of postseismic evolution of a seismically-triggered slump. The two processes are discussed in terms of morphology (assessed through digital stereographic interpretation of aerial photos and LiDAR-derived hillshade DEM) and internal structure (based on ERT and V/R soundings). The Factor of Safety calculation (Bishop method) analysis showed that, at least for the Balta landslide, an additional driving moment from seismic acceleration was necessary to trigger the movement. Such an approach is important within a multi-hazard risk preparedness and prevention framework, allowing us to define different levels of seismic shaking (in combination with variable climatic background conditions) and the related return periods.
\end{abstract}

\author{
Alexandru Onaca \\ Geography Department \\ West University of Timisoara \\ Timisoara, Romania \\ alexandru.onaca@e-uvt.ro
}

Anne-Sophie Mreyen
Department of Geology - Georisks and Environment
University of Liege
Liege, Belgium
anne-sophie.mreyen@rwth-aachen.de

\author{
Carmen Cioflan \\ Engineering Seismology Laboratory \\ National Institute for Earth Physics \\ Magurele, Romania \\ cioflan@infp.ro
}

Keywords- landslides; earthquakes; Vrancea seismic
region

\section{INTRODUCTION}

In seismically-active regions, earthquakes are representing a major cause of large, deep-seated landslides. The Vrancea Seismic Region (Curvature sector of the Eastern Romanian Carpathians) represents the most active intermediate-depth (focal depth 60-200 km) earthquake province of Europe. During the last 300 years, the region featured 12 earthquakes with $\mathrm{M}>7$, among which four events with magnitude above (and equal to) 7.5 and three between 7.7 and 7.9. Vrancea earthquakes are responsible for causing numerous geohazards, such as ground fracturing, groundwater level disturbances and possible deep-seated landslide occurrence (in form of rock slumps, rock-block slides, rock falls or rock avalanches). The purpose of this study is to outline the morphogenetic framework of such high magnitude and low frequency processes on the basis of two case-studies: Balta rock slide and Paltineni debris flow (Fig.1).

\section{DATA AND METHODS}

Landslides were assessed through field mapping backed-up by digital stereographic photo interpretation, using color aerial orthophotos (cell size $2 \mathrm{~m}$, resample from an original $0.5 \mathrm{~m}$ ) from the year 2005 (ANCPI Bucharest). DEM (cell size $20 \mathrm{~m}$ for the morphometric derivates, $2 \mathrm{~m}$ for the anaglyph interpretation) was obtained from linear 
interpolation of topographic contour lines (5 m interval) derived from DTM (Military Topographic Direction) 1:25000 topomaps (1960-1980). The lithological information was derived from the geologic maps (1:200000) of the Geological Institute of Romania. Earthquake data are in accordance with the ROMPLUS catalogue (National Institute for Earth Physics).
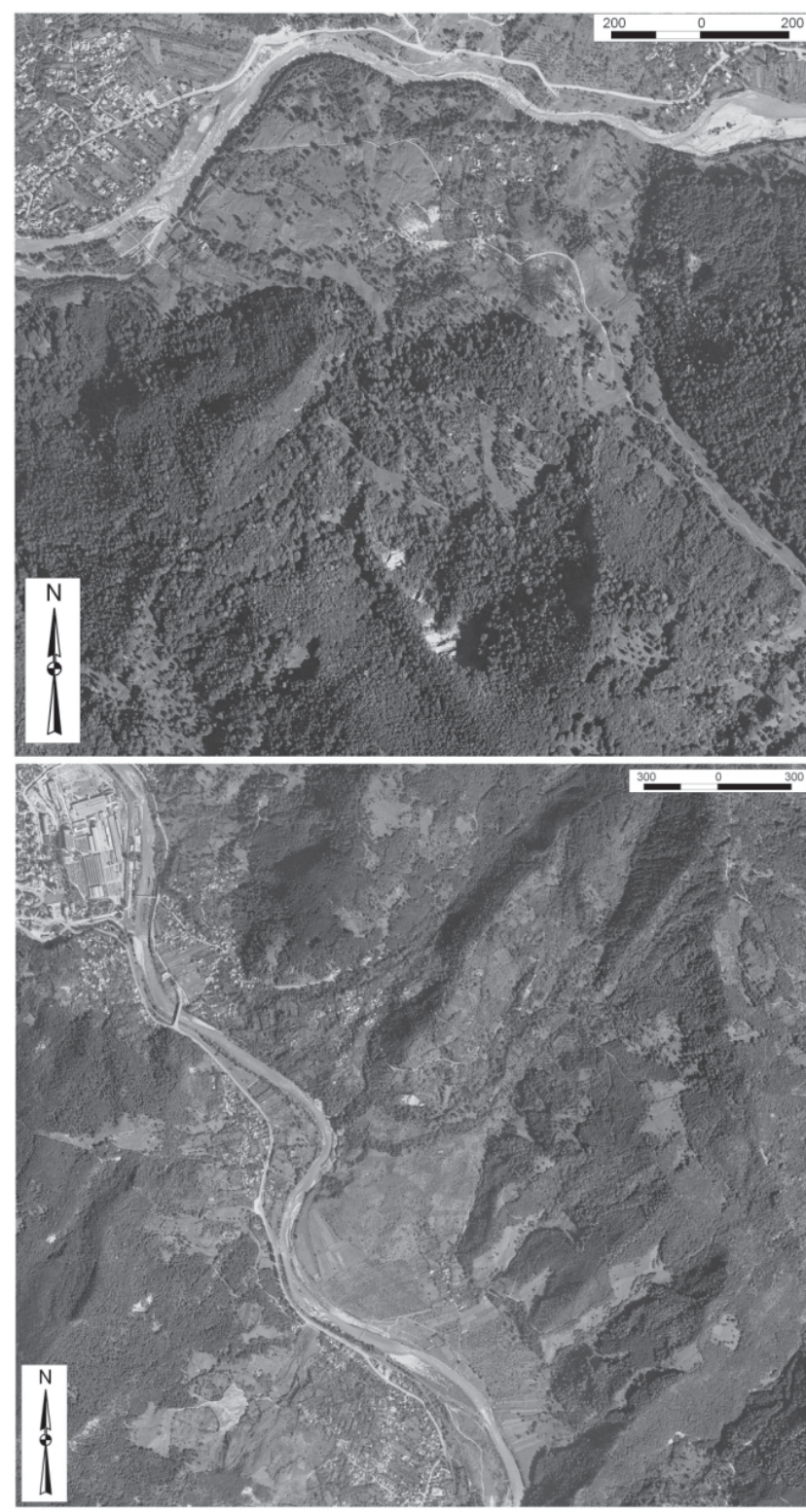

Fig. 1. The courses of Bâsca Rozilei (above) and Buzău (below) rivers, modified by the Balta and Paltineni earthquake-induced landslides (aerial photo, 2005, ANCPI)

ERT profiles consist of 2D electrical resistivity tomographies along four alignments of $395 \mathrm{~m}$ and one of $590 \mathrm{~m}$ long (resistivity data processed with the RES2DINV software from GEOTOMO). H/V method consists out of ambient noise measurements in order to determine the soil resonance frequency through microseismic spectral analysis. Factor of Safety for Balta rock slide was calculated using Bishop slope model. An apriori assessment of Simplified Newmark displacement (Newmark 1965, adapted for GIS analyses including Arias Intensity by Jibson et al.,1998, Miles and Ho,1999; Arias Intensity - m/s - was calculated for 1940 M7.7 earthquake and includes curvature amplification; critical acceleration evaluated for average geology: cohesion=100 $\mathrm{kPa}$, friction $=32^{\circ}$, density $=2200 \mathrm{~kg} / \mathrm{m}^{3}$ ) was provided by Micu et al., 2015.

\section{Preliminary Results}

The co-seismic landslide hypothesis arguments for Balta landslide (Fig.2) consists of: head scarp close to the ridge top and far away from the river; fault line vicinity; anti-dip slope; primary rotational slide not connected with channel processes. The field measurements and assessment outlined: the existence of a complex (rock slump, debris slide) landslide; a relict/dormant stage of activity; reactivations along the toe due to river undercut; total surface of 92 ha and above 70-80 m max. thickness of the landslide deposit; cause of an ancient landslide dam on Bâsca Rozilei River (river course changed); 10 households affected by creep-slide reactivations.

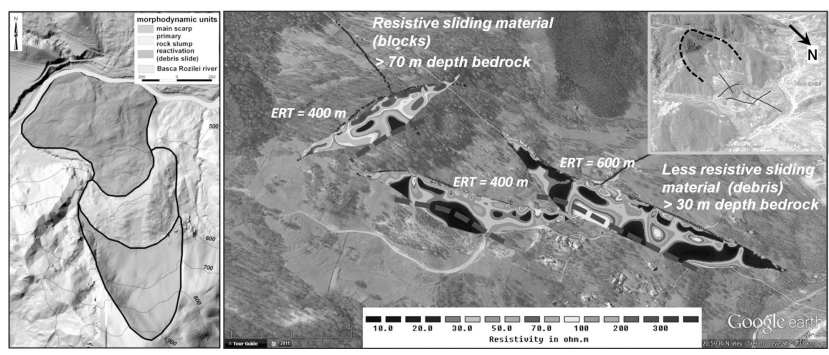

Fig. 2. Balta landslide

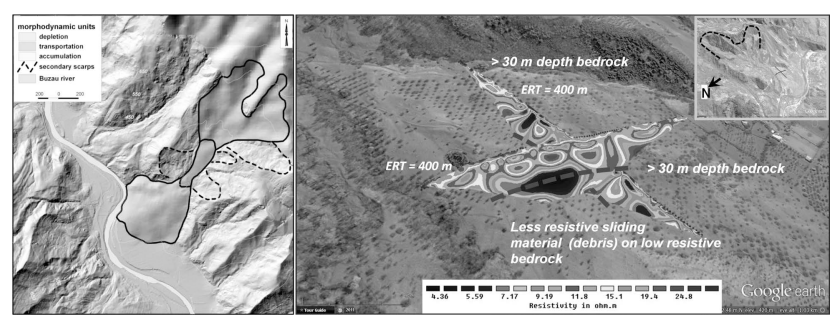

Fig. 3. Păltineni landslide

The earthquake-induced (potentially combined with precipitation) landslide hypothesis arguments for Păltineni landslide (Fig.3) consists of: sudden change (almost 90 degrees) of Buzau river flowing direction towards west with more than $400 \mathrm{~m}$ due to a sudden displacement of a large, compact mass of debris covering almost 25 hectares (50-60 m max. thickness). The field measurements and assessment outlined: a complex (rock slump, debris flow) landslide; a relict/dormant stage of activity; numerous toe reactivations (active river undercut); 80 ha surface and above 50-60 m max. thickness of the landslide deposit; river morphology major impact: Buzau river pushed by 400-450 m; active river undercut may cause large reactivations (landslide dam).

\section{CONCLUSIONS AND PERSPECTIVES}

Balta represents a complex landslide triggered by an above M 7.5 intermediate-focus earthquake. Balta primary 3D model (Fig.4) highlights the different processes (initial rock slump and subsequently-reactivated translational debris slide), backing-up the hypothesis of earthquake trigger. Paltineni represents a debris flow (highly likely) resulting out of the post-seismic evolution of a seismicallytriggered rock slump. Intermediate-deep earthquakes from 
Vrancea seismic region can trigger both co and postseismic massive, deep-seated slope failures within a relatively smooth relief (compared to the high mountain regions in Central Asia), considering possible geologic and topographic site-effects. The perspectives of this study are consistent: reconstruction of regional seismic history through paleo-seismic landslides; a better accelerometer instrumentation and monitoring of slopes, resulting in a more detailed understanding of the geologic and topographic potential accelerations; definition of different levels of seismic shaking (in combination with variable climatic background conditions) and the related return periods, as a proxi for multi-hazard risk preparedness and prevention frameworks.

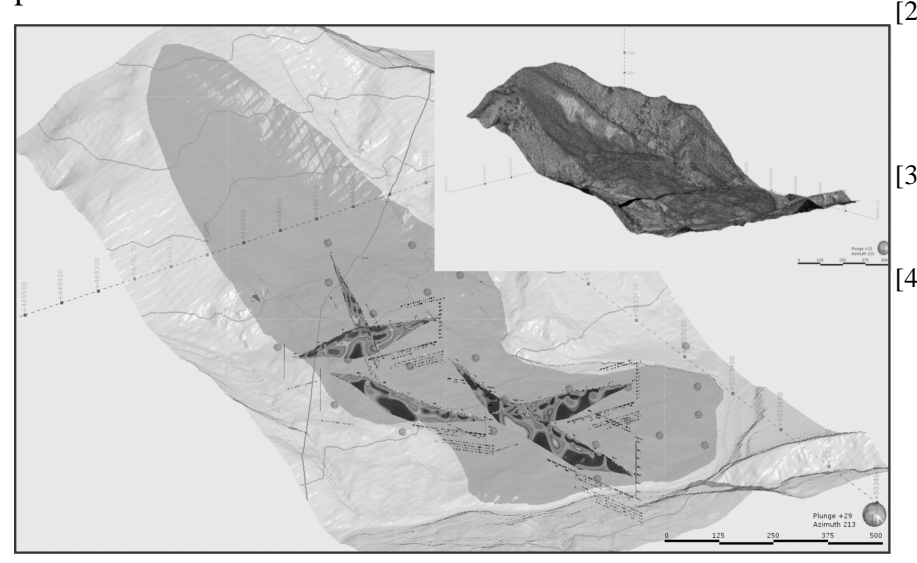

Fig. 4. 3D model of Balta landslide

\section{ACKNOWLEDGMENT}

This work has been performed within the AR-WBI Project Evaluation des risqué long-termes lies aux mouvements de masse declenches par les seismes dans la region de Vrancea and includes partial results from FP7 MC-ITN CHANGES and FP7 IncREO.

\section{REFERENCES}

[1] R.W. Jibson, E.L. Harp, and J.A. Michael "A method for producing digital probabilistic seismic landslide hazard maps-an example from the Los Angeles, California, area”, U.S. Geological Survey Open-File Report 98-113. 17 p., 2 pl., 1998.

[2] M. Micu, D. Balteanu, C. Ionescu, H.B. Havenith, M. Radulian, C. van Westen, M. Damen, and M. Jurchescu “A preliminary regional assessment of earthquake-induced landslide susceptibility for Vrancea Seismic Region”, Geophysical Research Abstracts, Vol. 17, EGU2015-12524, 2015.

[3] S.B. Miles and C.L. Ho "Rigorous landslide hazard zonation using Newmark's method and stochastic ground motion simulation”, Soil Dynamics and Earthquake Engineering, 18, pp. 305-323, 1999.

[4] N.M. Newmark, "Effects of earthquakes on dams and embankments”. Geotechnique, 15, pp. 139-160, 1965. 


\title{
The landslide database of the North-Eastern Romania
}

\author{
Mihai Niculiţă, Adrian Andrei, Cristina Lupu \\ Department of Geography, Geography and Geology Faculty \\ Alexandru Ioan Cuza University of Iaşi \\ Iaşi, Romania \\ mihai.niculita@uaic.ro, andrei_adrian9@yahoo.com, cristinalupu888@yahoo.com
}

\begin{abstract}
Landslide databases are key elements used for assessing the vulnerability and the risk associated with landslide hazard. Also these databases show us to what extent the landslides produce damages to the society, which are the most vulnerable parts and also add an important component to hazard analysis, by showing the temporal distribution of the phenomenon. Recently, this type of databases is used also for landslide rainfall initiation threshold analysis, being the base of landslide early warning systems at national and regional level.
\end{abstract}

We present a landslide database for the six counties of the North-Eastern Romania Development Region: Bacău, Botoşani, Iaşi, Neamţ, Suceava, Vaslui, covering events from 1850 to 2015. The main source for landslide information was represented by the newspapers, local, regional or national.

The database has 381 entries, 16 for Bacău County, 98 for Botoşani County, 52 for Iaşi County, 74 for Neamţ County, 78 for Suceava County and 63 for Vaslui County. The main source for the landslide events information were the local, regional and national news publications, and scientific publications and the time span of the identified landslide events is from 1900 to 2015 . Every landslide event was geolocated at least at commune level and located in time at least with the month and year. Beside the spatial and temporal localization, all the information related to the magnitude of the event (surface, volume, speed), the type of the landslide, the triggering causes, the damages that were induced to infrastructure and houses and any other information that has a meaning for landslide research.

The majority of the landslide events are reactivations, which occur from February to August, the biggest frequency periods being June-July, when heavy rainfall occurs and March-April when snowmelt and rainfall overlay. The speed of the events is small enough to allow evacuation of the population, so there was no human loess found. Beside natural causes (snowmelt and intense rainfall), there are landslides related to human activities: deforestation, road cutting, oil and gas mining. The main types of damages are related to houses and road infrastructure.

While the database is not complete, because of the different density of the sources, it is showing the general pattern of landslide reactivation and damages scenarios caused by landslides in the north-east region of Romania.
Keywords - historical landslide inventory; North-Eastern Romania; landslide hazard; landslide risk

\section{INTRODUCTION}

The landslide hazard and risk assessment requires spatial and temporal data of landslide events [1, 2, 3]. This information is given by historical sources, since the use of aerial and satellite imagery is limited to the last 60 to 80 years. While the use of remote sensing images allow us to elaborate complete landslide inventories for a limited amount of time, which in most cases is overlaid with the last climatic cycle, the historical information can be used to cover several climatic cycles, but the obtained inventory will not be complete. The historical information on landslides, in the past and today is related to events that happened in areas where society and landslides meet [3, 4]. Although not complete this type of landslide inventories are actually needed for assessing scenarios of vulnerability in order to objectively create risk scenarios $[5,6,7]$.

\section{STUDY AREA}

North-Eastern Romania Development Region covers six counties: Bacău, Botoşani, Iaşi, Neamţ, Suceava, Vaslui, and three physiographic units: Eastern Carpathians, the Moldavian Subcarpathians and the Moldavian Plateau. The population of this region is of 3.7 million people and its surface is of approx. $37000 \mathrm{~km}^{2}$. While the geology and the geomorphology of the study area is variate, the landslide triggering mechanisms are similar. Rainfall and hydrogeological water represent the main trigger, but also human activity generates landslide events.

The climate of the study area is temperate continental characterized by rainfall maximum in June-July and minimum in January-February, with mean annual temperature values ranging from -1 to $10^{\circ} \mathrm{C}$ and mean annual rainfall ranging from 1000 to $400 \mathrm{~mm}[8,9]$.

For an in depth characterization of the climate variability we have chosen to illustrate the situation of Iași city surroundings according to ROCADA dataset [9].

The daily, monthly and early rainfall data (Fig. 1) show that the 1970-1990 period was a wet period, compared with the pre 1970 and after 1990 period which 
are dry. The rainiest months are June, July, August and May. The trends for seasonal rainfall (Fig. 2) show that in the wet period (1970-1990) the winter and autumn had lower rainfall values, while the spring and summer had bigger rainfall values, compared with the dry periods. An interesting pattern is shown by the monthly heat map plot (Fig. 3), where we can see that in the wet period the rainiest yearly months slide between May and September, while in the dry period this pattern is missing.
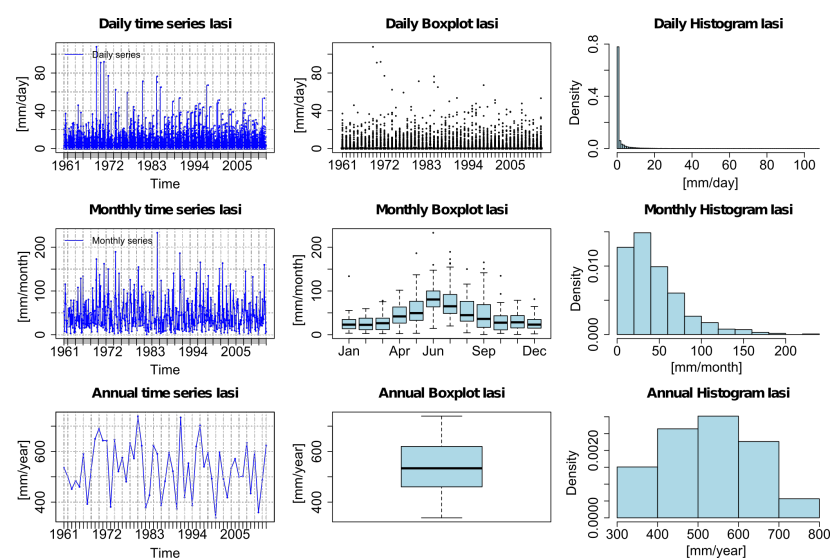

Fig. 1. Iasi surroundings daily, monthly and yearly trends of rainfall data for the 1961-2013 interval (rainfall data source: ROCADA [9])
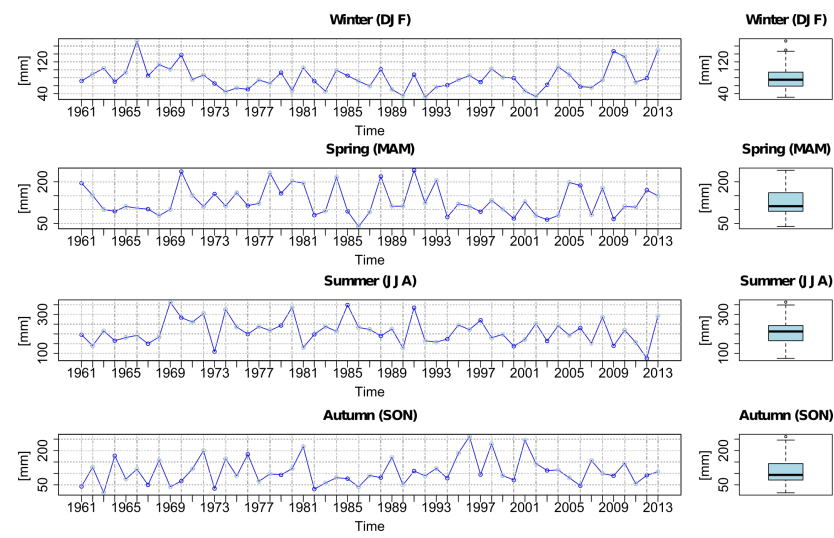

Fig. 2. Iasi surroundings seasonal trends of rainfall for the 1961-2013 interval (rainfall data source: ROCADA [9])

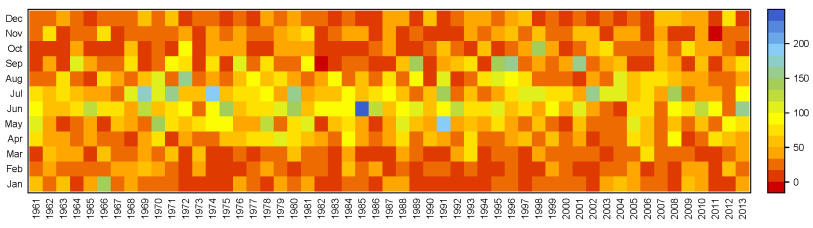

Fig. 3. Iasi surroundings monthly precipitation for the 1961-2013 interval (rainfall data source: ROCADA [9])

Spatial patterns of maximum rainfall for the study area can be seen in Fig. 4, two hot spots of maximum rainfall appearing, one in the mountainous area of Neamt and Bacău counties, and another along the Prut valley in Iași and Vaslui counties.

\section{MATERIAL AND METHODS}

The main source of landslide information varies with the time. Before 1990 the main sources are the scientific papers, or information from newspapers. After the 1990 the main source is represented by the newspapers, local, regional or national.

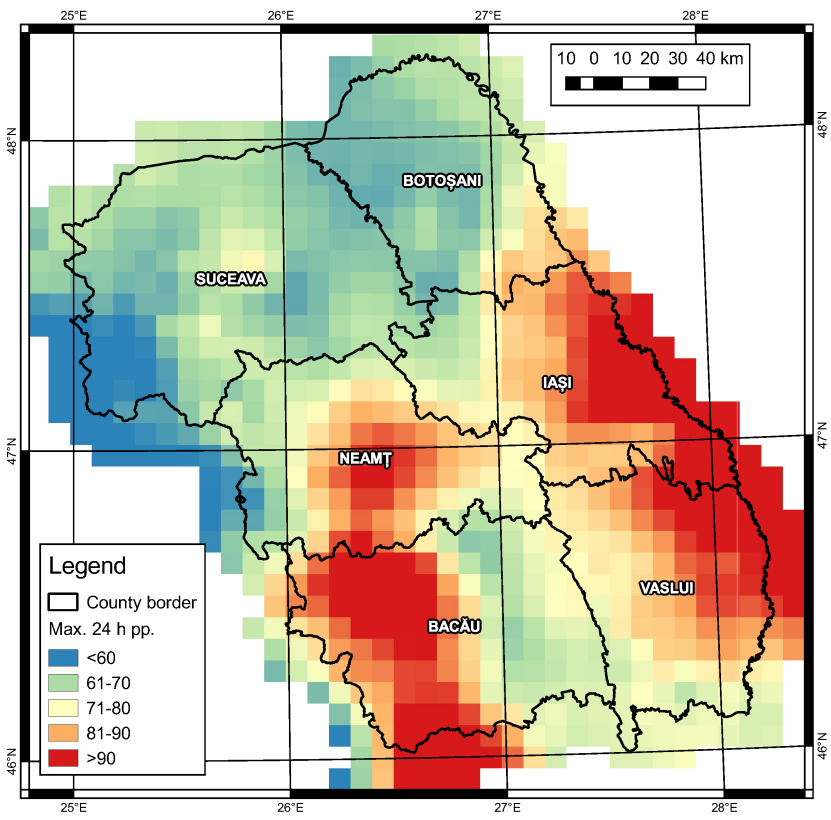

Fig. 4. Maximum precipitation in 24 hour period for the 1961-2013 interval (rainfall data source: ROCADA [9])

The database was created as an Open Office Calc sheet (Fig. 5).

\begin{tabular}{|c|c|c|c|c|c|c|c|c|c|}
\hline Date & \multicolumn{4}{|l|}{ Location } & \multicolumn{2}{|c|}{ County } & \multicolumn{2}{|c|}{ Comuna/Oras } & Siruta \\
\hline $30 / 03 / 2015$ & \multicolumn{4}{|c|}{ sat Gîteni, comuna Răcăciuni } & \multicolumn{2}{|l|}{ Bacau } & \multicolumn{2}{|c|}{ Răcăciuni } & 24766 \\
\hline $06 / 2010$ & \multicolumn{4}{|c|}{ Mărgineni, sat Valea Budului } & \multicolumn{2}{|l|}{ Bacău } & \multicolumn{2}{|c|}{ Mărgineni } & 20466 \\
\hline $1 / 04 / 2015$ & \multicolumn{4}{|c|}{ Răcăciuni, Gâsteni } & \multicolumn{2}{|c|}{ Bacă } & \multicolumn{2}{|c|}{ Răcăciuni } & 24766 \\
\hline $31 / 03 / 2015$ & \multicolumn{4}{|l|}{ Băcăciuni } & \multicolumn{2}{|l|}{ Bacău } & \multicolumn{2}{|c|}{ Răcăciuni } & 24766 \\
\hline \multirow[t]{2}{*}{2015} & \multicolumn{4}{|l|}{ Gâsteni } & \multicolumn{2}{|l|}{ Bacău } & \multicolumn{2}{|c|}{ Băcăciuni } & 24766 \\
\hline & \multicolumn{4}{|l|}{ Sesuri } & \multicolumn{2}{|l|}{ Bacău } & \multicolumn{2}{|c|}{ Măgiresti } & 23387 \\
\hline \multirow[t]{7}{*}{ Type } & Road & Length & Speed & & ume & Surt & & \multicolumn{2}{|l|}{ Damages } \\
\hline & DC 110 & & & & & & & \multicolumn{2}{|c|}{ au fost afectate 21 de lc } \\
\hline & DN 2G & & & & & & & \multicolumn{2}{|c|}{ a fost afectată conducta } \\
\hline & & & & & & & & \multicolumn{2}{|c|}{ peste 60 de persoane al } \\
\hline & & & & & & & \multicolumn{3}{|c|}{60 de persoane si-au gă } \\
\hline & & & & & & & \multicolumn{3}{|c|}{ locuinte distruse } \\
\hline & & & & & & & & \multicolumn{2}{|l|}{ sat mutat } \\
\hline
\end{tabular}

Fig. 5. A snapshot of the tabellar format of the database

The main information gathered was the temporal and the spatial localization of the landslide event. Beside this crucial information any other pertinent information that was present was registered: landslide type (Cruden and Varnes classification or it was a reactivation or new landslides if the type wasn't registered), landslide speed, landslide surface, landslide volume, affected infrastructure (building, roads, pipes), damages and the source of information.

The time resolution is variate, either a day (DD/MM/YYYY) or at least the month (MM/YYYY) or the year (YYYY). This date was registered in the start time column. If the landslide evolved more than one day, the final time column was registered, if not, the column remained unfilled.

The space resolution is variate, at least at commune level. If the information was available, the village or the precise spatial location was delineated as a polygon. The commune coding and the name were inserted. 


\section{RESUltS AND DisCUSSIONS}

The database has 381 entries, 16 for Bacău County, 98 for Botoșani County, 52 for Iaşi County, 74 for Neamţ County, 78 for Suceava County and 63 for Vaslui County. The following sources were used: newspaper and television news $(60 \%)$, public reports $(27 \%)$, urban plans (8\%), monographs and research papers (4\%) and $\mathrm{PhD}$ theses (1\%).

The majority of the landslides are reactivations, and not always the typology of the landslide can be described from the available information.

Comparing the density of the events geocoded at commune level (Fig. 6) with the spatial patterns of maximum 24 hour rainfall, we can see that there is no match. This most probably happens because of the incompleteness of the database [10].

The number of landslides per year (Fig. 7) shows a sharp increase of data availability after the 1990 and after 2000.

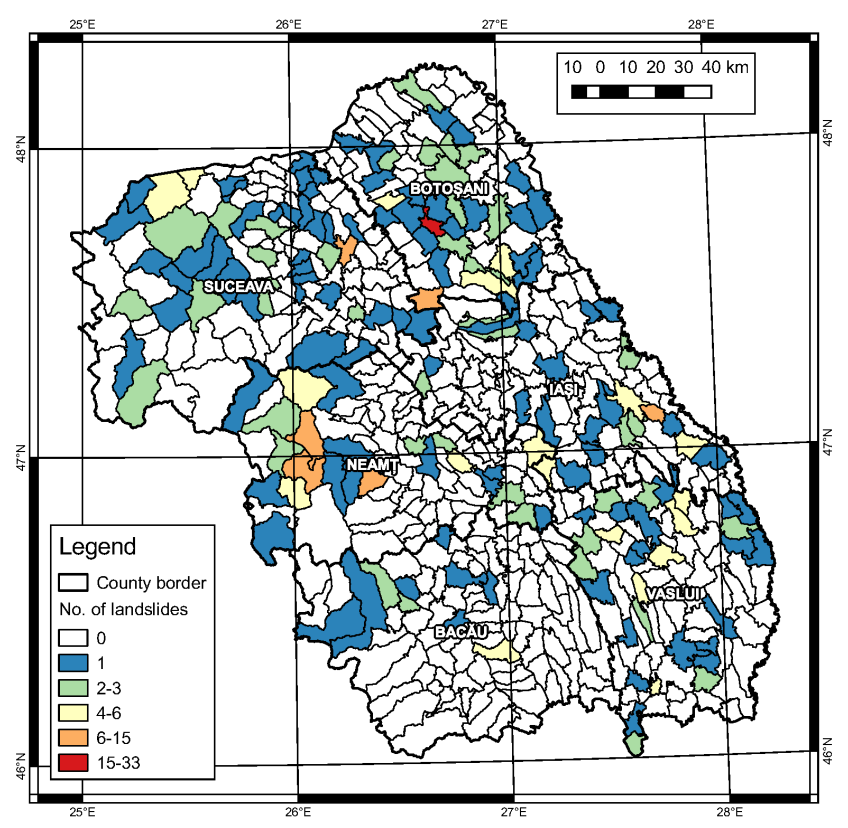

Fig. 6. The spatial distribution of landslide events, geocoded at commune level

The two most important monthly hotspots for landslide triggering are June-July and March-April. This show that the landslide mechanism in the study area in mainly related to heavy summer rainfall after wet winter and spring periods, or snowmelt and rainfall conditions met in wet springs. Late summer or autumn and winter snowmelt triggering is rare, but it happens.

Most often the reactivations strike the same area, like Botoșani city, where 33 reactivations were registered. The biggest damage was produced also by a reactivation: T,icău (Iași city neighborhood) reactivation, in which 370 houses were destroyed (12 - 13 April 1942).

The magnitudes of the landslide events of the reactivations are in general small and the landslide speed is small enough to allow safe evacuation. This is probably the explanation to the fact that no human loss was registered.
The landslides affect mostly the houses, churches, cemeteries, roads, railways (in 1992 the railway sector between Dîngeni and Săveni was affected by landslides on a sector of $100 \mathrm{~m}$, which finally because of the lack of investments generated the closure of this $53.4 \mathrm{~km}$ railway sector), industrial infrastructure (Zemeș, Bacău County landslide with a surface of 42 ha and a volume of 3 million $\mathrm{m}^{3}$, which affected 47 oil pumps and one house, triggered by the oil drilling activities) and other public infrastructure form the study area.

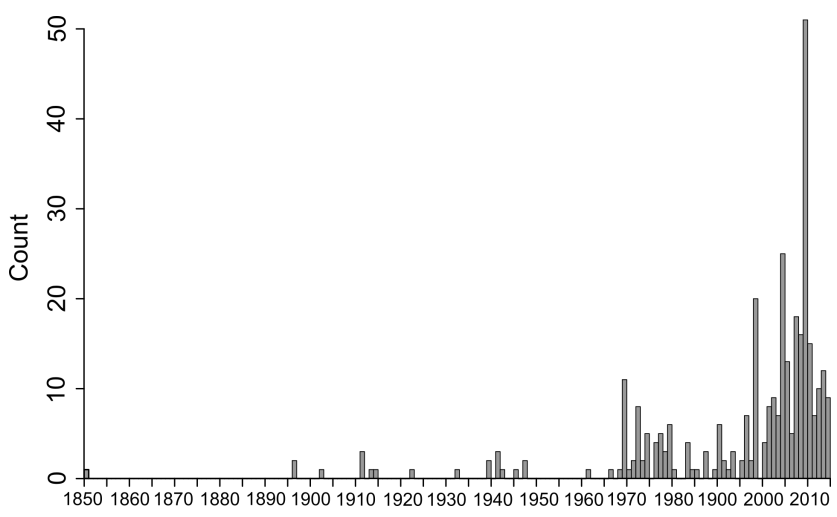

Fig. 7. Yearly landslide frequency for the study period.

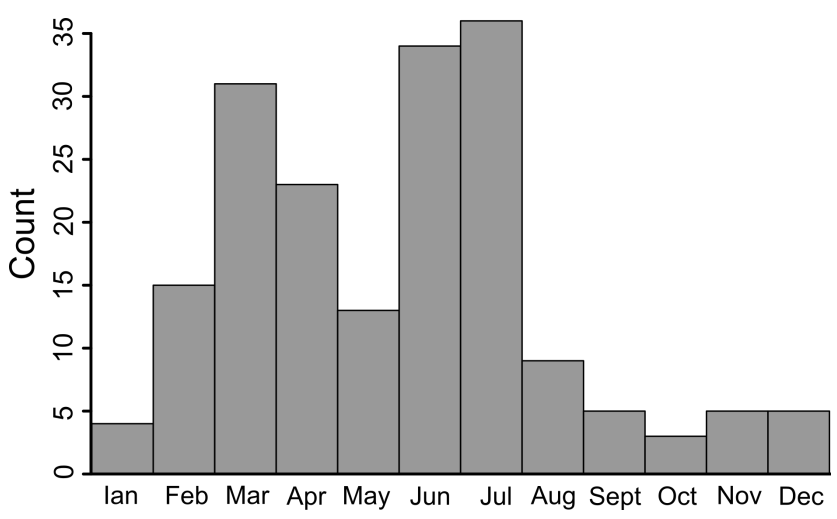

Fig. 8. Monthly landslide frequency.

Another important effect of landslide reactivation is the relocation of parts or entire villages:

- $\quad$ in 1975 Pungești village and 1978 Dragomirești, village, Vaslui County;

- $\quad$ in 1974-1975 Cîrlig village, 1996 Pârcovaci village and 1999 Todirel village, Iași County.

\section{CONCLUSIONS}

The present work represents one of the first regional historical landslide inventories, representing a lower boundary situation regarding the spatial and temporal frequency of landslides. We have identified 381 events that generated losses for houses, churches, roads, railways, industrial facilities and other infrastructure networks. No human loss was registered, mainly because of the reduced magnitude and speed of landslide events.

The main triggering factors are intense summer rainfall events and hydrogeological water related to overlaid snowmelt and rainfall, during the year two intervals are characterized by a great frequency of events: March-April and June-July. 
The majority of the recorded events are actually reactivations of old or relict landslides.

Although the database is not complete, it is usable to argue the need for an in depth analysis of past landslide events and to create vulnerability and risk scenarios. The need for further study is requested by the possible impact of future rainy periods and by the change in human pressure on hillslopes through the change in construction materials and urban/rural sprawl.

\section{REFERENCES}

[1] T. Glade, "Landslide hazard assessment and historical landslide data - an inseparable couple?,” in T. Glade, P. Albini, F. Francés, eds., The Use of Historical Data in Natural Hazard Assessments, Advances in Natural and Technological Hazards Research, vol. 17, 2001, pp. 153-168.

[2] A. Carrara, G. Crosta, and P. Frattini, "Geomorphological and historical data in assessing landslide hazard", Earth Surface Processes and Landforms, vol. 28, no. 10, pp. 1125-1142, 2003.

[3] M. Klose, Landslide databases as tools for integrated assessment of landslide risk. Springer, 156 p., 2015.
[4] D.B. Kirschbaum, A. Robert, Y. Hong, S. Hill, and A. Lerner-Lam, "A global landslide catalog for hazard applications: method, results, and limitations”, Natural Hazards, vol. 52, no. 3, pp. 561575, 2010.

[5] F. Guzzetti and G. Tonelli, "Information system on hydrological and geomorphological catastrophes in Italy (SICI): a tool for managing landslide and flood hazards”, Natural Hazards and Earth System Sciences, vol. 4, pp. 213-232, 2004.

[6] S. Pereira, J.S. Zezere, I.V. Quaresma, and C. Bateira, "Landslide incidence in the North of Portugal: analysis of a historical landslide database based on press releases and technical reports", Geomorphology, vol. 214, pp. 514-525, 2014.

[7] F. Guzzetti, C.P. Stark, and P. Salvati, "Evaluation of flood and landslide risk to the population of Italy," Environmental Management, vol. 36, no. 1, pp. 15-36, 2005.

[8] A.-E. Croitoru and Minea, "The impact of climate changes on rivers discharge in Eastern Romania”, Theoretical and Applied Climatology, vol. 120, pp. 563-573, 2015.

[9] A. Dumitrescu and M. Bîrsan, "ROCADA: a gridded daily climatic dataset over Romania (1961-2013) for nine meteorological variables”, Natural Hazards, vol. 78, no. 2, pp. 1045-1063, 2015.

[10] M. Polemio and O. Petrucci, "Occurrence of landslide events and the role of climate in the twentieth century in Calabria, southern Italy”, Quaterly Journal of Engineering Geology and Hydrogeology, vol. 43, pp. 403-415, 2010. 


\title{
InSAR analysis of Sentinel-1 data for monitoring landslide displacement of the north-eastern Copou hillslope, Iaşi city, Romania
}

\author{
Nicuşor Necula \\ Department of Geology, Geography and Geology \\ Faculty \\ Alexandru Ioan Cuza University of Iaşi \\ Iaşi, Romania \\ neculanicusor93@gmail.com
}

\author{
Mihai Niculiţă \\ Department of Geography, Geography and Geology Faculty \\ Alexandru Ioan Cuza University of Iaşi \\ Iaşi, Romania \\ mihai.niculita@uaic.ro
}

\author{
Giulia Tessari, Mario Floris \\ Department of Geoscience \\ University of Padova \\ Padova, Italy \\ giulia.tessari.1@unipd.it, mario.floris@unipd.it
}

\begin{abstract}
This work is aimed at showing the potential use of Synthetic Aperture Radar interferometry (InSAR) for landslide investigation and for the evaluation of the slope displacement over time and identification of unstable areas for the north-eastern Copou hillslope. The available Sentinel1 data have been processed using Advanced Differential Interferometry (A-DInSAR) techniques which includes Permanent Scatterers Interferometry (PSI) and Small BAseline Subset (SBAS).
\end{abstract}

Starting from two or more SAR phase images for the same area with different time acquisition it is possible to measure small deformations of the ground surface by using remote sensing techniques such as InSAR. The detection of ground displacement can be derived if the topographic phase contribution is removed from the generated interferogram. The generation and subtraction of synthetic interferogram allows to create displacement maps, and to overcome its major limitations (temporal and geometric decorrelations, phase unwrapping, the atmospheric component) different algorithms have been developed belonging to two main families: the Permanent (Persistent) Scatterers Interferometry (PSI) and the Small BAseline Subset (SBAS). Even though the techniques are exploiting different strategies, both of them were developed with the same purpose, to identify and measure the ground deformations with sub-centimeter precision.

For our study area, the north-eastern part of Iaşi city, over 100 different phase Sentinel-1 images kindly provided by ESA have been processed using both techniques (PSI and SBAS), with the stacking tool of the software Sarscape. The SAR images covers a period of more than 2 years (October 2014 - January 2017) and include both orbits: ascending and descending.
Iaşi area is affected by slow moving landslides, which make our testing area to have a good environmental setting for the above mentioned techniques to be applied. According to our results, the Ţicău unstable area has been identified to have in several sectors considerable velocity values, greater than $3 \mathrm{~mm} /$ year. These values represent the mean velocity along line of sight (LOS) and illustrate the displacement trend of ground surface over the study period.

Keywords - landslide; SAR interferometry; Sentinel-1; PSI; SBAS; Iași; Romania

\section{INTRODUCTION}

Recent advances in radar based techniques and higher quality information from different type of sensors have significantly improved the accuracy of monitoring ground deformations and increased its applicability for various natural hazardous phenomena [1]. A powerful remote sensing approach which is capable to measure the low rates of surface displacements using interferograms is based on Synthetic Aperture Radar Interferometry (InSAR) techniques. An interferforogram is created considering the information in the phase difference of two SAR images acquired in different times over the same area.

The Earth surface displacements is manifesting as vertical and horizontal movement conducting to a tridimensional displacement vector. This case is specific to landslides behavior which represent phenomena whose natural diffuse displacement is occurring along the slope and is highly influenced by the inclination and the aspect of the slope [2]. While in the case of subsidence and uplift phenomena the vertical displacement is dominant, for landslides, the flow mechanism has an important component along the inclination angle of the slope which 
has a great contribution to the horizontal displacement, as well as toward the aspect, that indicates the direction of sliding in the horizontal plane. However, because of the nearly polar orbits of the SAR satellites, the north-south component of displacement cannot be measured unless additional information on ground motion is known [3].

Since the beginning of the 2000s, different methods have been proposed in order to calculate long term surface displacements. The two main algorithms are the Permanent Scatterers Interferometry (PSI) $[4,5]$ and the Small BAseline Subset (SBAS) [6]. Some other algorithms have been developed to adapt these methods to specific needs, or attempt to combine both of them to obtain better results.

\section{STUDY AREA}

The study area, located in the north-eastern part of Copou hillslope (Fig. 1), has been chosen to identify very slow movements of stabilized landslides. Since 1900, landslide reactivations sometimes ended with destruction of houses and damage to streets [7, 8], but in recent years after remediation works it is considered as a stable area. However, considering its past behavior (several reactivations, one in the ' 42 and the other in '69) [7, 8] and the geological environment (clayey and sandy layers with a fluvial terrace and slope deposits caprock), slow movements which can affect the structure of houses are expected. This context represents a good opportunity for satellite image analysis to identify possible critic (unstable) areas and trying to prevent future damages to inhabitants, buildings and infrastructure.

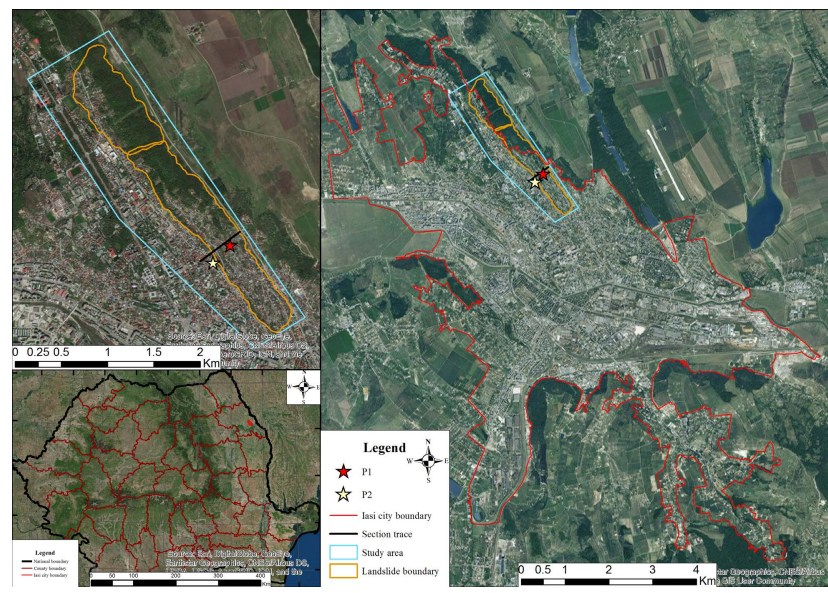

Fig. 1. Geographical location of the study area within Iași municipality

The main landslide conditioning factor is the geology of this area which consists of Bassarabian (Middle Sarmatian) clays interbedded with sand layers and covered by quaternary deposits (fluvial and slope deposits, loess Fig. 2). The caprock of permeable loess and slope deposits allow the formation of an aquifer in the basal sand and gravel layer, at the contact with the impermeable clays [8]. Permanent springs are known in the area, and especially after consecutive rainy autumns, winters and springs [8], or during summer storms [7]. Reactivations of the scarp of the landslide body happened, mainly affecting portion of the hillslope where drainage measures were not implemented before (the reactivations migrated from the southern part to the northern part of the hillslope) [7, 8].

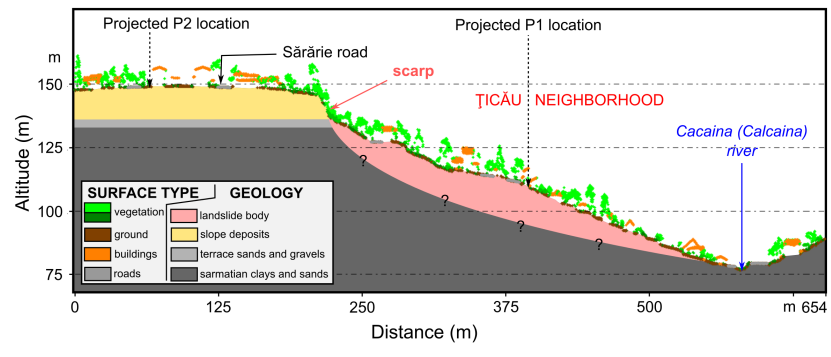

Fig. 2. Geomorphological section through Copou north-eastern hillslope (the direction appears in Fig. 1 as a black line)

At present, the landslide is stabilized by drainage wells and drainage trenches, mainly located in the scarp area. Furthermore, surface deformation is stopped by passive stabilizing infrastructure (anchors, gabion and concrete walls - Fig. 3).

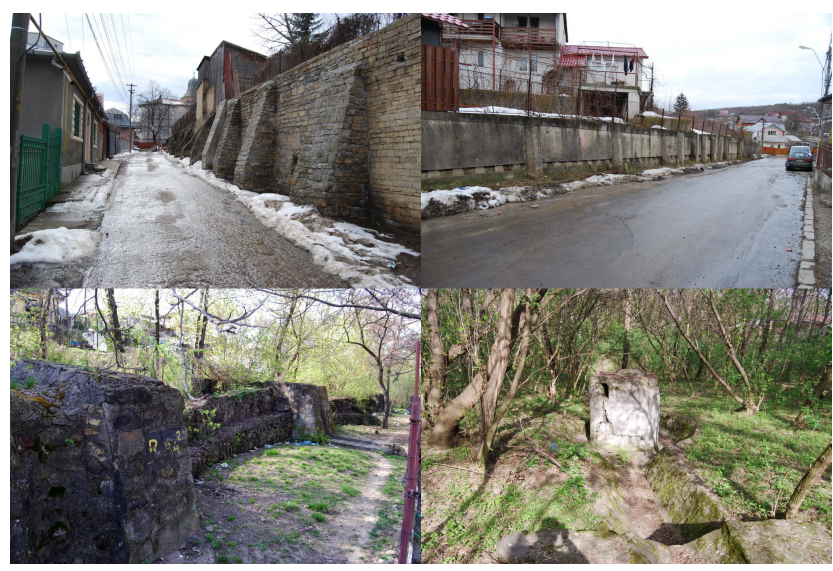

Fig. 3. Passive mechanic infrastructure used for the stabilization of the hillslope

\section{METHODS}

For our study case, good framework of the landslide which is characterized by low rates of displacement with a dominant west to east sliding direction, made possible to apply SAR interferometry techniques. Thus, using the Sentinel-1 data provided by ESA, the two main techniques, PS and SBAS, have been used to obtain information about the velocity and the evolution of displacement in Line of Sight (LOS) direction.

The Permanent Scatterers algorithm [2 - 5] considers the phase information of isolated targets characterized by high_reflectivity and temporal stability of the phase signal in all the SAR data with respect to the master image. Although this technique presents a significant advantage for landslide monitoring with respect to in situ measurements, it is dependable to coherent targets, for this reason urbanized areas are preferred for this technique to be applied. The dense vegetation which covers a part of the landslide made impossible to obtain any results from PS technique, for this reason the SBAS approach was more appropriate in order to have more information over the area. The Small Baseline Subset (SBAS) method $[3,6]$ is relaying on the small baseline between 2 time acquisitions. Practically, the algorithm is pairing all the images which are defined by the threshold parameters for temporal and normal baseline. The main advantage of this technique is that it takes into account also low coherence areas to extend the spatial coverage of the final result, being a 
useful tool for vegetated areas characterized by diffuse targets. Moreover, this technique can be used when few SAR images are available because this algorithm increases the redundancy of the created interferograms.

Despite the fact that these approaches rely on different strategies they have been developed and improved for the same purpose, to overcome the main limitations of DInSAR techniques, reducing temporal and geometric decorrelations, supporting phase unwrapping step and estimating the atmospheric component, in order to obtain results with sub-centimeter precision.

More than 100 Sentinel-1 SAR data acquired for both ascending and descending orbits were processed, covering a time interval of approximately two years, from October 2014 to January 2017. The Interferometry Stacking tool of SARMAP's SARscape software package 5.4 has been used.

\section{RESUlTS AND DISCUSSIONS}

Based on the analysis of Sentinel-1 images, velocity maps along the line of sight direction for both tracks using PS and SBAS techniques have been created. For ascending tracks (Fig. 4) velocity values ranging from -3 to -10 $\mathrm{mm} / \mathrm{y}$, and locally even higher, have been obtained inside the landslide compared with the stable points outside of its border. To overcome the lack of information in the area with dense vegetation the SBAS technique was also considered, but unfortunately low coherence area influenced the unwrapping step and naturally the final results of SBAS.

Excluding the vegetated area where no results came by, the SBAS output for the rest of the area is similar with the one obtained through PS method which make the analysis to be consistent. The evidence of surface displacement was also checked and found in the field (Fig. 6): wall cracks, wall buldging and tilted trees.

The time series of displacements for two different points (Fig. 7) have also been plotted to illustrate the difference between a moving point (P1 - red star) located in the sliding area and a stable one (P2 - yellow star) outside of its border. The displacement trend of each point is representative for the area they belong to, for the unstable area displacement values over $2 \mathrm{~cm} / \mathrm{y}$ have been recorded.

The projection of results along the vertical and eastwest direction was also calculated using the mean velocity datasets from PS ascending and descending orbits [9, 10]. The projected results appears to be in accordance with the small inclination values of the slope, the landslide being characterized by a west to east movement direction rather than a vertical one.

\section{CONCLUSIONS}

The use of interferometry for landslide assessment appears to be convenient in order to detect the deformation produced in the affected area making InSAR techniques a helpful tool. Although it has some limits, its low costeffectiveness and the huge number of points with high precision obtained for large areas in a fast way make InSAR techniques comparable with the standard methods such as GPS surveys and optical leveling, and certainly reliable for future investigations of slope instability.

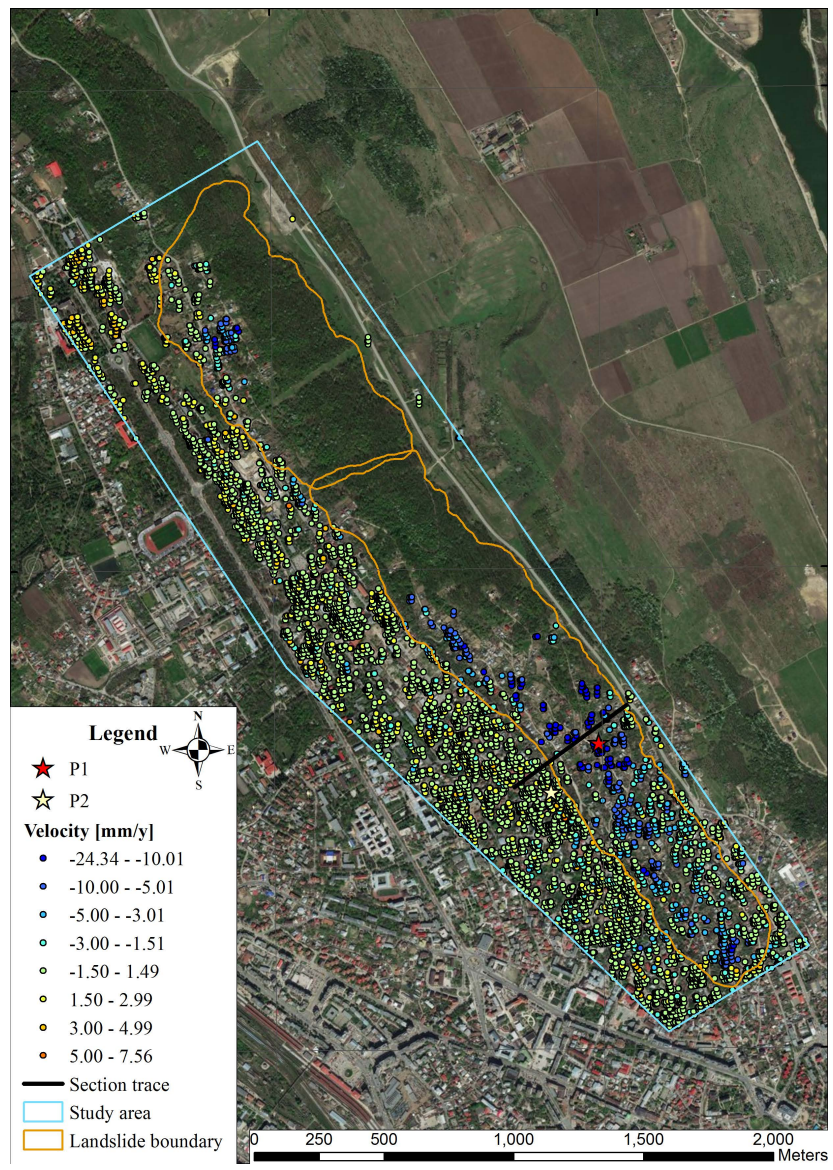

Fig. 4. PS results

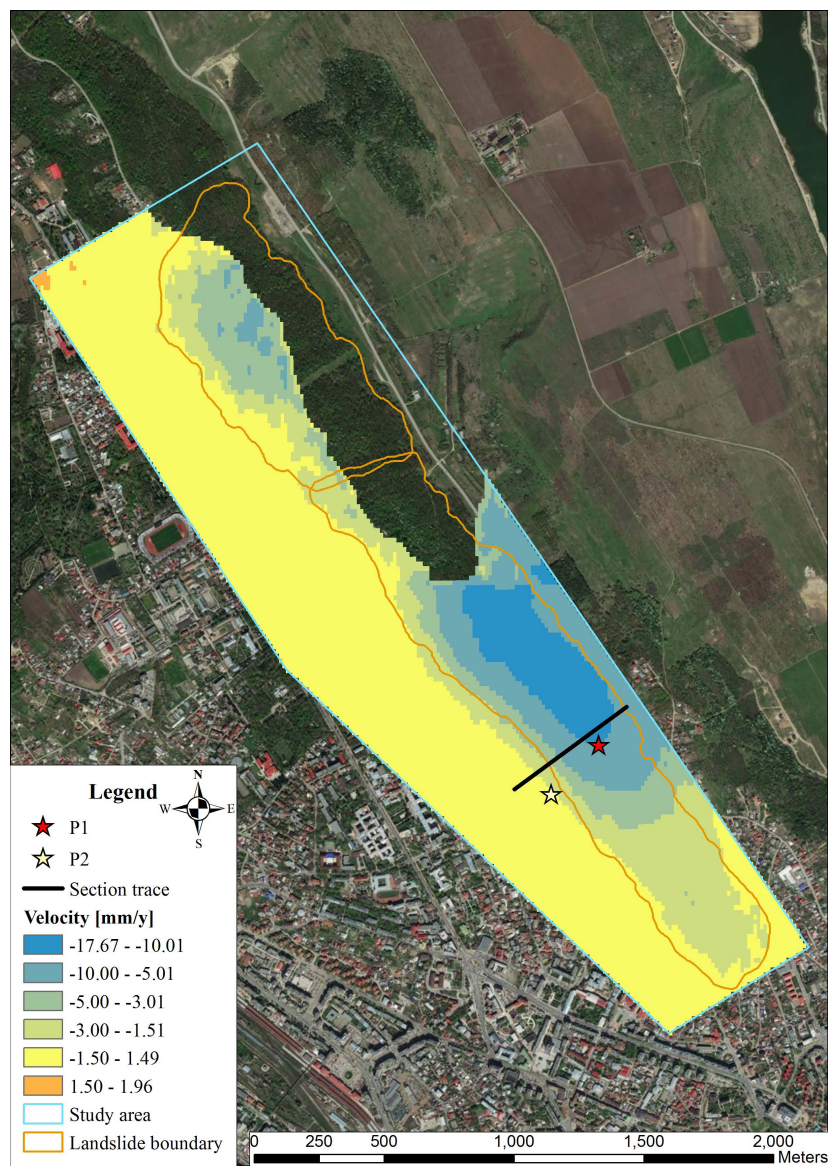

Fig. 5. SBAS results. 


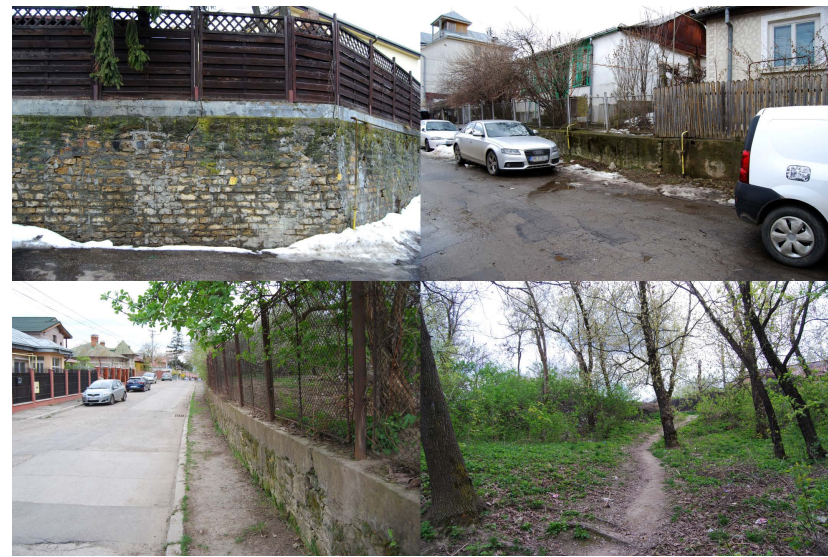

Fig. 6. Evidences of surface displacement: upper left and right - wall cracks, bottom left - wall buldging, bottom right - tilted trees.

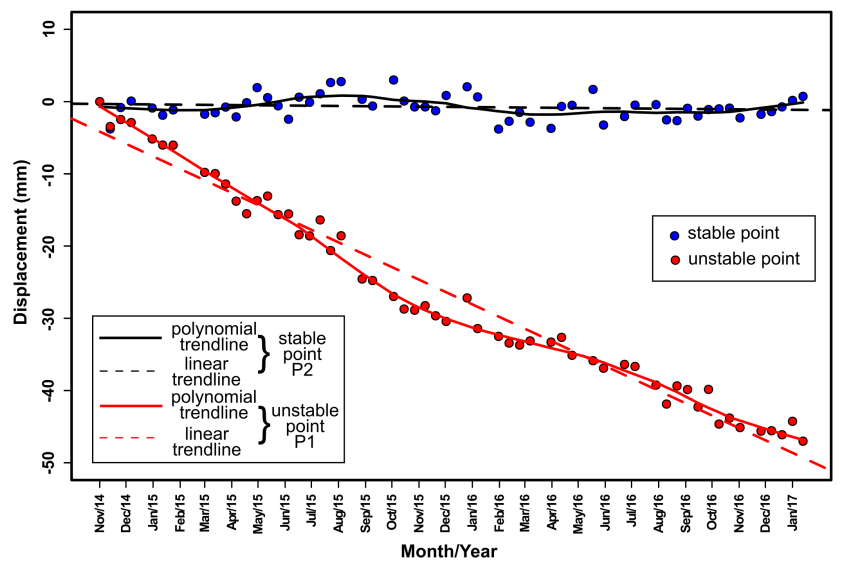

Fig. 7. Displacement rates for a stable and unstable PS point (the location of the points are shown in Fig. 1: stable point - P2 yellow star, unstable point - P1 - red star).

The ability to generate displacement information on stabilized landslides, as is the case for Copou hillslope is crucial to identify hazardous areas, where reactivations might occur. Considering that the last climatic cycle (after the '90) is a dry one, and future rainy periods coupled with a change in house constructions style (one level small houses are replaced by 2-3 level villas) will increase the risk associated with landslide reactivations.

Nevertheless, the analysis of Sentinel-1 data using PS and SBAS technique identified moving areas along the
Copou hillslope where deformations of $10 \mathrm{~mm} / \mathrm{y}$ occur. However, a thoroughly analysis is planned in order to obtain more information over the slope using the SBAS approach, also to extend the time span of analysis by processing previous available SAR images of ESA archive (ERS 1, ERS 2, ENVISAT) as well as analyzing high resolution X-band data of COSMO-SkyMed constellation.

\section{ACKNOWLEDGMENT}

We have used the computational facilities given by the infrastructure provided through the POSCCE-O 2.2.1, SMIS-CSNR 13984-901, No. 257/28.09.2010 Project, CERNESIM (L4).

\section{REFERENCES}

[1] A. Moreira, P. Prats-Iraola, M. Yuonis, G. Krieger, I. Hajnsek, and K. Papathanassiou, “A tutorial on Synthetic Aperture Radar”, IEEE Geoscience and Remote Sensing Magazine, vol. 1, pp. 6-43, March 2013.

[2] C. Colesanti and J. Wasowski, "Investigating landslides with space-borne Synthetic Aperture Radar (SAR) interferometry", Engineering Geology, vol. 88, pp. 173-199, 2006.

[3] J. Wasowski and F. Bovenga, "Investigating lanslides and unstable slopes with satellite Multi Temporal Interferometry: Current issues and future perspectives”, Engineering Geology, vol. 174, pp. 103138, 2014.

[4] A. Ferretti, C. Prati, and F. Rocca, "Nonlinear subsidence rate estimation using permanent scatterers in differential SAR interferometry”, IEEE TGRS, vol. 38, no. 5, pp. 2202-2210, 2000.

[5] A. Ferretti, C. Prati, and F. Rocca, "Permanent scatterers in SAR interferometry”, IEEE TGRS, vol. 39, no. 1, pp. 8-20, 2001.

[6] P. Berardino, G. Fornaro, R. Lanari, and E. Sansosti, “A new algorithm for surface deformation monitoring based on small baseline differential SAR interferograms”, IEEE TGRS, vol. 40, no. 11, pp. 2375-2383, 2002.

[7] V. Băcăuanu, “Alunecările de teren din partea nord-estică a Dealului Copou - Iași”, Anal. Șt. Univ. „Al. I. Cuza” Secț. a II-a XVI, pp. 143-146, 1970. (in Romanian)

[8] N. Macarovici, “Observații asupra alunecărilor de teren de la Iași din primăvara anului 1942”, Rev. șt. „V. Adamachi”, XXVIII (2-3), pp. 185-188, 1942. (in Romanian)

[9] L. Cascini, G. Fornaro, and D. Peduto, “Advanced low- and fullresolution DInSAR map generation for slow-moving landslide analysis at different scales”, Engineering Geology, vol. 112, 2010, pp. 29-42.

[10] D. Di Martire, G. De Luca, M. Ramondini, and D. Calcaterra, "Landslide-related PS data interpretation by means of different techniques”, in Landslide Science and Practice, C. Margottini, P. Canuti and K. Sassa, eds., Springer, 2013, pp. 347-355. 


\title{
Tree-ring based reconstruction of snow avalanche frequency in Şureanu Mountains (Southern Carpathians, Romania)
}

\author{
Olimpiu Traian Pop, Flaviu Meseșan, Ionela-Georgiana Gavrilă, Cosmin Timofte \\ Laboratory of Dendrochronology \\ Faculty of Geography, Babeș-Bolyai University \\ Cluj-Napoca, Romania
}

\begin{abstract}
Snow avalanches represent a widespread phenomenon in the Carpathians, damaging forests, properties, infrastructures and causing fatalities. In remote mountain areas, historical records of snow avalanche activity are commonly lacking. Trees repeatedly disturbed by snow avalanches record evidence of past events in their annual rings. The main purpose of the present study was to analyze tree-ring records in order to reconstruct frequency and spatial extent of past avalanche activity along a path located on the southern slope of Şureanu Peak (2059 m a.s.l.). Samples collected from 54 Norway spruce trees (Picea abies (L.) Karst.), heavily disturbed by snow avalanches, have been analyzed and their tree-growth anomalies identified (e.g. scars, callus tissues, the onset sequences of tangential rows of traumatic resin ducts, compression wood, growth suppression and release sequences). The growth anomalies found within the tree rings served to date past avalanche events, back to late 19th century. Finally, the minimum frequency of snow avalanches has been determined. In the studied area, dendrogeomorphic methods provide the most consistent avalanche event chronology and can further contribute to an accurate avalanche hazard zonation.
\end{abstract}

Keywords - snow avalanches; tree rings; Norway spruces; event frequency; Şureanu Mountains (Romania)

\section{INTRODUCTION}

Snow avalanches affect various mountain areas in the world and represent one of the rapid debris transfer mechanisms in these environments. Avalanche activity repeatedly damages inhabited areas, infrastructures, forests and causes fatalities. In the avalanche prone areas, understanding the process frequency and magnitude is crucial for a precise hazard zonation. High-resolution hazard mapping is needed to reduce the avalanche-related risk, particularly in mountain areas with human activity (e.g. the winter tourism resorts).

In remote mountain areas, hazard zonation is commonly hampered due to a lack of historical records regarding the past snow avalanche activity. This is the case for the central part of Şureanu Mountains (Southern Carpathians, Romania), where the snow avalanche history is undocumented by archival records. Here, the coniferous forests have repeatedly experienced destructive snow avalanches in the past, as attested by the presence of damaged trees along the paths. It has been already proven that dendrogeomorphology offers the possibility to accurately date and determine the spatial extent of past snow avalanches occurring across the forested slopes. So far, in Şureanu Mts., dendrogeomorphic studies have never been applied to exploit the valuable information stored within tree-ring archives, despite the great potential that trees offer in this area for such studies. Here, multiple avalanche paths are located next to the ski area. The aim of this study was to use various dendroecological indicators in order to reconstruct snow avalanche frequency along one of the path in Şureanu Mts.

\section{STUDY AREA}

Şureanu Mts. belong to the Southern Carpathians Range (Fig. 1). In their central area, the maximum altitude reaches 2059 m. a.s.l. on the Şureanu Peak. Below the main peak, multiple avalanche paths have their release areas located on steep slopes $\left(>25^{\circ}\right)$, and extend downward across coniferous forests mainly composed of Norway spruce trees (Picea abies (L.) Karst.). The investigated Auşelu avalanche path is located on the southern slope below Şureanu Peak, extending downward from the subalpine shrub area at $2050 \mathrm{~m}$ a.s.l and crossing the forest. It reaches the gentle slopes at about $1600 \mathrm{~m}$. a.s.l., in the confluence area with another avalanche path from the right side.

\section{METHODS}

\section{A. Field sampling and laboratory analyses}

After the identification of avalanche path on the orthophotoplans and in the field, disturbed trees growing within the path have been selected for sampling (Fig. 2). A total number of 54 P. abies trees have been sampled, their spatial position being determined using a GPS device. Sample collection includes increment cores extracted with a Pressler borer from 36 trees (minimum 2 cores per tree) and stem discs cut from 18 fallen and/or topped trees. 


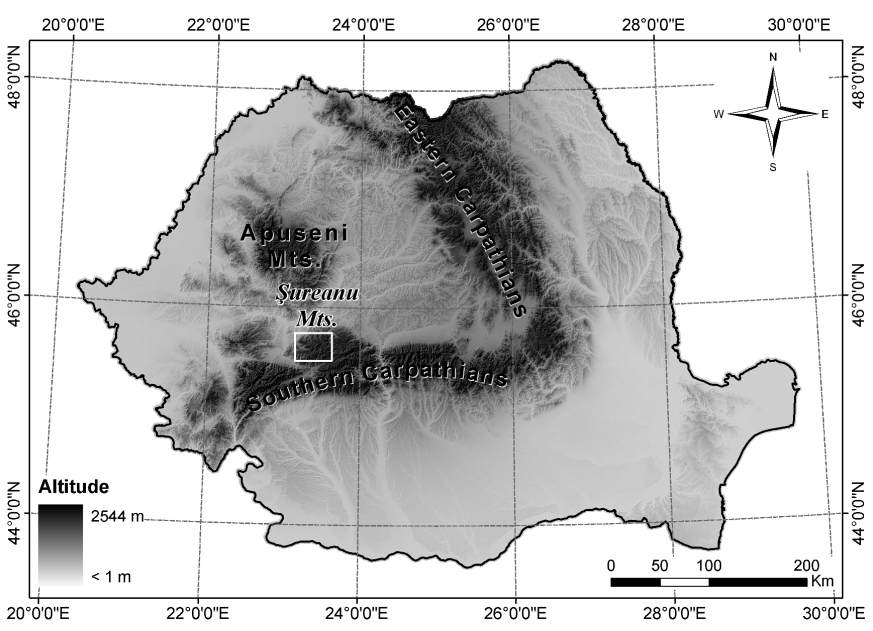

Fig. 1. Map location of Șureanu Mountains in Romania.

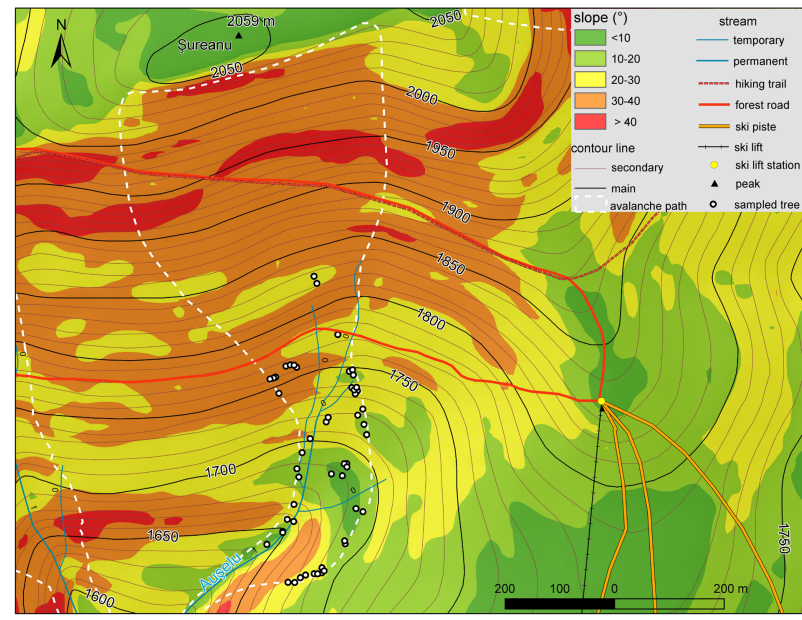

Fig. 2. Location of the Auşelu avalanche path and spatial distribution of the sampled trees.

In laboratory, all samples (cores and stem discs) have been prepared for analysis following the standard dendrochronological procedures [1]. After the air-drying, sanding and age determination by ring counting, ring widths have been measured to the nearest $0.01 \mathrm{~mm}$ using a digital LINTAB positioning table connected to a Leica stereomicroscope and TSAP-Win ${ }^{\mathrm{TM}}$ Professional 0.22 software [2]. To detect dating errors (i.e. missing or false rings), tree-ring series have been cross-dated. The quality of the cross-dating was evaluated statistically using the program COFECHA [3] and visually by the graphical function of the program TSAP-Win. Reference chronology obtained previously from undisturbed trees growing at several tens of km distance in Parang Mts. [4] served for cross-dating with growth chronologies of disturbed trees, to identify and correct the missing/false rings. Samples from damaged trees have been analyzed, in order to detect growth anomalies related to mechanical stress caused by snow avalanches. Growth disturbances included mainly the onset sequences of compression wood, tangential rows of traumatic resin ducts accompanied by callus tissue partly covering the margins of the scars, as well as the growth suppression sequences (GS) other than those caused by climatic factors [5].

\section{B. Avalanche event determination}

Event reconstruction was based on the type, intensity and number of growth disturbances (GDs) detected within growth rings. Scars (SC) in association with callus tissue (CT) have been identified mainly within cross-sections. The onset sequences of traumatic resin ducts (TRD), compression wood (CW) and growth suppressions (GS) identified within both cores and cross-sections have been separated by intensity classes (low, medium and high intensity), according to the classification of [6]. An avalanche activity index $\left(I_{t}\right)$ has been then calculated using the formula proposed by [7]:

$$
I_{t}=\left(\sum_{i}^{n}={ }_{1} R_{t} / \sum i^{n}={ }_{1} A_{t}\right) \times 100
$$

- $\quad R$ represents a tree that presents at least one growth reaction in a specific year $t$;

- $\quad A$ represents the tree alive in that year $t$.

The following two criteria have been used to reconstruct a distinct avalanche event:

(1) the presence of clear GD, such as SC, CT and TRD or CW reactions with high and medium intensity found in minimum three disturbed trees form the ten trees alive in that year;

(2) the calculated avalanche activity index $\left(I_{t}\right)$ having a minimum threshold value of $10 \%$

\section{RESULTS}

\section{A. Avalanche frequency reconstructed}

The oldest sampled tree's first growth ring is dated back in 1877, while the youngest sampled tree's first ring is from 2002. Taking into account the number, type, intensity of growth anomalies and the calculated values of $I_{t}>10 \%$, it is possible to reconstruct a number of 10 past avalanche events spanning the 1877 - 2016 period (Fig. 3). It represents a minimum number of events that dendrogeomorphic methods allowed to be reconstructed. Other possible event years could also be determined, but the small number and weak intensity of growth disturbances in these years doesn't allow us to reconstruct with high confidence a distinct event. The event year 2000 defined by the largest number of disturbed trees showing growth reactions (40 trees), as well as the highest values of $I_{t}(78 \%)$ can be considered as one of the largest avalanche event which occurred along the investigated avalanche path during the reconstructed period.

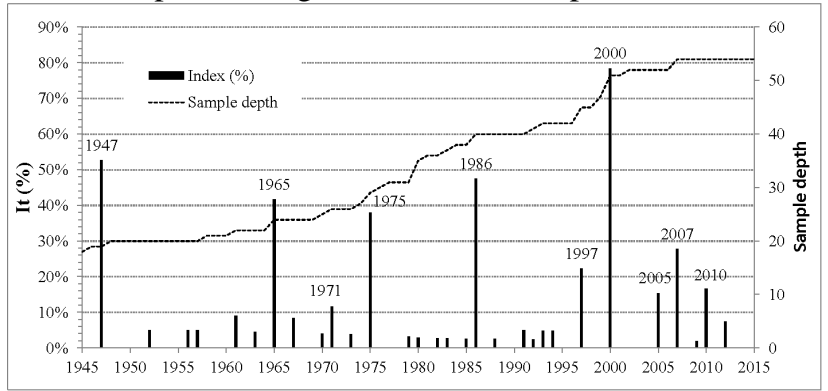

Fig. 3. Event frequency histogram reconstructed with tree rings for the Aușelu avalanche path. 


\section{CONCLUSIONS}

The results of the present dendrogeomorphic study serve to reconstruct the minimum frequency of snow avalanches along the Auşelu avalanche path. Tree ring records provide clear evidence of 10 events that occurred in the past between 1887 and 2016. Dendrogeomorphic methods can contribute significantly to snow-avalanche hazard zonation, helping also in planning decisions in the studied area. Further analyses on additional trees sampled are necessary, in order to identify supplementary events and to complete the avalanche chronology of the investigated path. More investigations extended also to other avalanche paths in the area should offer a better understanding of the snow avalanche patterns at a regional scale.

\section{REFERENCES}

[1] O.U. Bräker, "Measuring and data processing in tree-ring research - a methodological introduction”, Dendrochronologia, vol. 20, pp. 203-216, 2002.

[2] RINNTECH, 2017. TSAP-Win ${ }^{\mathrm{TM}}$-Software for tree-ring measurement, analysis and presentation. http://www.rinntech.com.

[3] R. L. Holmes, "Computer-assisted quality control in tree-ring dating and measurement”, Tree-ring bulletin, vol. 43, no. 1, pp. 6978, 1983.

[4] O.T. Pop, I.G. Gavrilă, Gh. Roșian, F. Meseşan, A. Decaulne, H.H Iulian, and T. Anghel, “A century-long snow avalanche chronology reconstructed from tree rings in Parang Mountains (Southern Carpathians, Romania)”, Quaternary International, vol. 415, pp. 430-440, 2016.

[5] F.H. Schweingruber, Tree Rings and Environment. Dendroecology. Paul Haupt, Bern, Switzerland, 1996.

[6] M. Stoffel and C. Corona, "Dendroecological dating of geomorphic disturbance in trees”, Tree-Ring Research, vol. 70, no. 1, 3-20, 2014.

[7] J.F. Shroder, "Dendrogeomorphological analysis of mass movement, Table Cliff Plateau, Utah”, Quaternary Research, vol. 9, pp. 168-185, 1978. 


\section{History of Holocene fluvial activity in Romania: evidences based on absolute dating}

\author{
Maria Rădoane, Ioana Perșoiu, Francisca \\ Chiriloaei, Delia Robu, Nicolae Rădoane \\ Ștefan cel Mare University of Suceava \\ Suceava, Romania \\ radoane@usm.ro
}

\begin{abstract}
The main objective of this paper is to illustrate how was carried the reconstitution of geomorphological activity of rivers in Romania at different times of the Holocene based on the interpretation sedimentation contexts with dated samples, the sediment quality, their deposition styles, relict morphologies and others. The database compiled was processed using bivariate and multivariate statistical techniques or the probability distribution functions. The secondary objectives relate to: (i) Establishing a chronology of fluvial activity in Romania? (ii) How were felt Holocene climatic thresholds (identified in various proxies) in fluvial activity? (iii) How river chronology correlates with other environmental and geoarchaeological in our geographic area? (iv) In this research stage, we can explore some links with Central Europe fluvial chronologies?
\end{abstract}

Keywords - fluvial chronologies; absolute dating; probability density functions; Holocene

\section{APPROACHING PREMISES}

Regarding the knowledge evolution on fluvial landforms and processes, the year 2010 stands out as a reference year in grouping the study objectives: (i) before 2010, the fluvial geomorphology research has focused mainly on present-day and modern channel dynamics, on fluvial processes related to human impact and other driving factors; (ii) after 2010, many notable attempts have occurred, with studies focused on the better understanding of the style and of the magnitude of channels changes for different timescales (secular, millennial, Late Holocene, Holocene, Late Glacial and transition to Holocene). Over the last 6 years several scientific studies based on absolute dating were published, with results correlated with multidisciplinary investigations. Due to the increased number of references on past climate and hydrological events, geomorphologists wanted to correlate them with the magnitude of fluvial activity, responsible for the morphologic and sedimentologic adjustment styles of river channels. The required information are stored in sedimentary archives (litho-stratigraphic units whose morphological, granulometric, geochemical, biological characteristics indicate the mechanisms and physical processes which contributed to their deposition) and are dated by one of the known techniques. Because these structures are rich in biogenic material, the most used method to evaluate their age was radiocarbon dating.

\author{
Constantin Nechita \\ National Institute for Research and Development in \\ Forestry "Marin Drăcea" - INCDS, \\ Câmpulung Moldovenesc, Romania
}

In many regions of Europe absolute dating databases of the sedimentary archives were achieved, processed using the methodology elaborated by [1] and [2]. Thus, from Great Britain [3, 4], Spain [5], Germany [6] and Poland [7, 8], several hundreds of absolute dating of sedimentary archives were statistically approached and conclusions regarding the periods with high fluvial activity registered in the considered regions were obtained. In light of these results we want to report our own results throughout the objectives of the present study.

In Romania, significant progress was achieved as regards the chronology of the Holocene. [9] summed the palaeoclimatic data sources and climate reconstructions for the last 15000 years in Romania. The fluvial sedimentary archives (from floodplain and floodplain terraces) and sedimentary archives from small sedimentary basins (small lakes, peatbogs, swamps, glacial lakes) which are directly related with a drainage basin and network, were the main focus of our study. By approaching the meta-analysis technique, respectively, "the use of a systematic review procedure and common set of statistical techniques to combine the results of several studies" [10], we compiled a database of over 400 absolute dating collected from sedimentary units who had at source a hydrological event of a certain magnitude.

The aim of this work is the review of the existent records (published or in press), regarding the chronology of fluvial activity of Romanian rivers following some exceptional hydrological events. On this basis we intend to reconstruct the geomorphological fluvial activity of rivers in different moments of Holocene, to identify how some certain climatic thresholds were felt in the answer of fluvial processes, the role of human impact, correlation of other environmental and geoarchaeological chronologies from our geographical area.

\section{STUDY AREA AND THE DATABASE}

The compiled database totaled 404 stratigraphic units dated, distributed in Romania and across the border (in the case of Somes, Cris and Mures rivers). The data were collected from over 80 publications, and a large number of dates are provided by our research team (n 90). The samples are originating from fluvial environments adjacent to actual rivers or palaeo-paths 
located on floodplain or alluvial fans $(n=155)$ and lacustrine environments with direct connection to a drainage network $(n=249)$. Complementary, we have also used dendrochronological dating by using the dendrochronological information preserved in the subfossil trunks embedded in fluvial sediments. Also, we have considered 29 stands of living trees, Q. robur and $Q$ petraea distributed all over Romanian territory, which dendrochronological series with annual resolution helped us to detail the climatic conditions from 1800 until present.

Depositional environments that we followed were: palaeo-channels fills, riverbank deposits (lateral and vertical accretion), fluvial terraces (below $10 \mathrm{~m}$ relative altitude), colluvia, palaeosoils, wetland deposits within floodplains. The overview was completed with the inclusion of sedimentary units of small lakes and transitional peats and bogs located on the fluvial network.

The studied reaches were identified respect to river length from headwaters to the sampling point, relative altitude (compared to river bed elevation) and absolute altitude of the sampling place, the depth of sedimentary profile from which the sample was sampled, a short describing of the channel morphology, dated terrace height etc. There were 95 sites selected (Fig.1), within 1 site being inventoried from 1 to $11-19$ sedimentary structures dated.

Two river systems have been our focus for many years, through individual researches, within the research projects developed or $\mathrm{PhD}$ thesis elaborated, thus the higher density of the inventoried sites is represented by Somes River and its tributaries (35\%) and by Siret River and its tributaries (28\%). The other data concerns: Mures River and its tributaries, Tisa's tributaries, Danube, Teleorman, Olt. The obtained database was processed by using some specific statistical methods: cumulative curve of calibrated ages BP; probability density functions (PDFs) determination for variate datasets, statistical tests and sensitivity analysis.

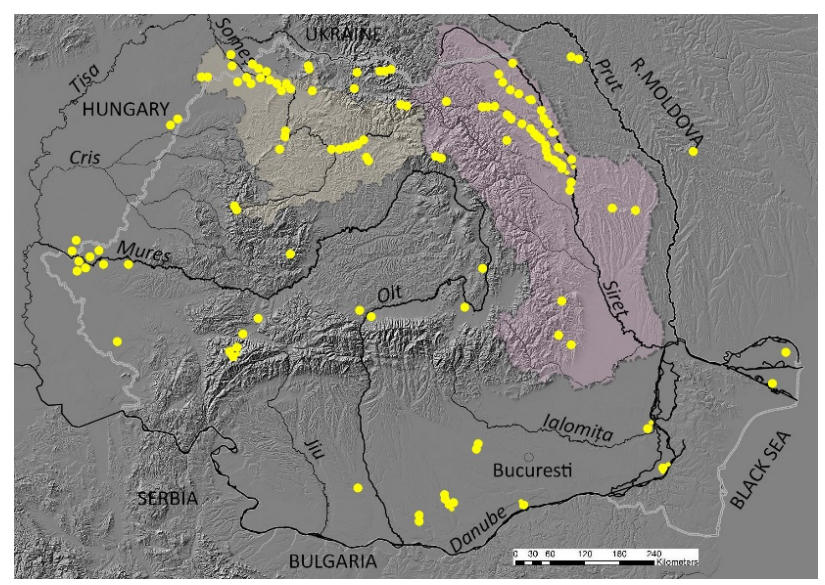

Fig. 1. The location of sites with absolute dating in: fluvial, limnological transition to fluvial network, and dendroclimatological environments. Siret and Somes drainage basins are identified by the higher density of absolute dating.

\section{RESUlTS AND DisCUSSIONS}

The graphical representation of calibrated ages of sedimentary units by using rank age curve (Fig. 2) does not represent a straight line. If the sedimentation rate in
Holocene, both in fluvial facies and lacustrine environment, should be uniform, then also the rank age curve would be a straight line. Actually, the existence of numerous episodes of increasing/decreasing of sedimentation rates determined a curving of successive distribution of rank ages. A higher curving is identified in the area of small ages also, given by the higher number of existent samples, then appear rhythm breaks all over the Holocene period and another bending of ages can be noticed towards the transition period from Early Holocene to Late Glacial.
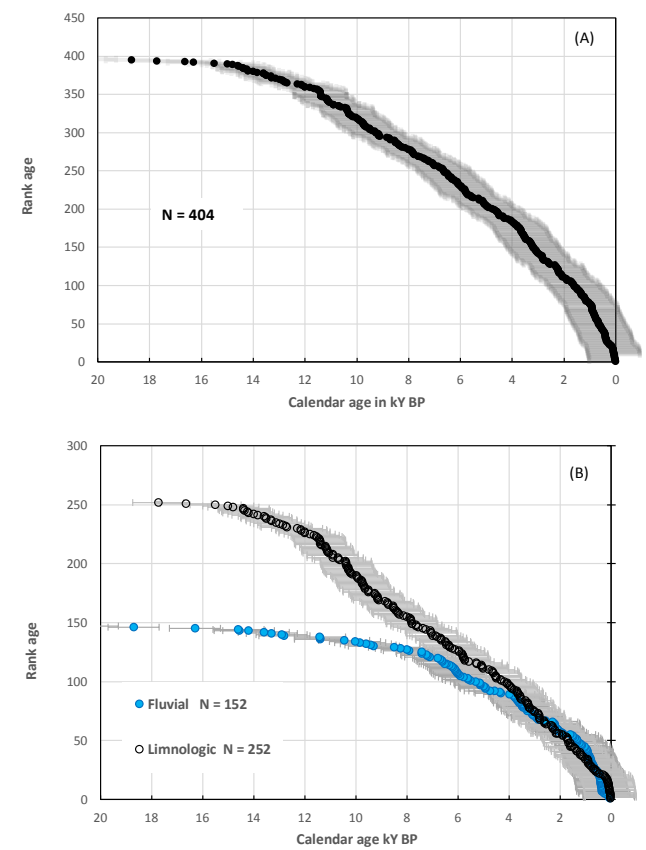

Fig.2. Cumulative curve of rank ages, showing the minimum and maximum ages and variation band of $2 \delta$ : A. Cumulative curve for all

data; B. cumulative curve for absolute dating dataset in fluvial environment (blue) and lacustrine environment related to fluvial one (black).

Data analysis of the two sedimentation areas shows a common trend of nonuniformity sedimentation, but which is more accentuated in the case of fluvial environment. At least for the ages older than $8 \mathrm{kyr}$, the rate of fluvial processes is changing, a possible cause could be the relative small number of data available for this period. Instead, in the lacustrine environment the sedimentation process displays a certain constancy (with small jumps), with the biggest change taking place towards the end of the Holocene.

For the last 7000 years, the interval where density of absolute age data is higher in fluvial domain from Romania, we have built the probability density functions curve (Fig. 3A) which shows that in some sequences of time, the probability that a change in sedimentation rate in certain floodplain facieses seems to be higher than in other sequences of time. For this geomorphologic process to take place, a flux water discharge of high magnitude was needed. This might have been the case of successive floods, capable to dislodging sediments from source area and to transport them towards the deposition zones.

Sediment accumulation in small sized lakes is very sensitive to dynamic processes from the supply basin (in this case the erosion and sediment transport in direct relationship to water discharges). We do not discuss here 
the combination of other factors driving the "cascade" of the listed processes.

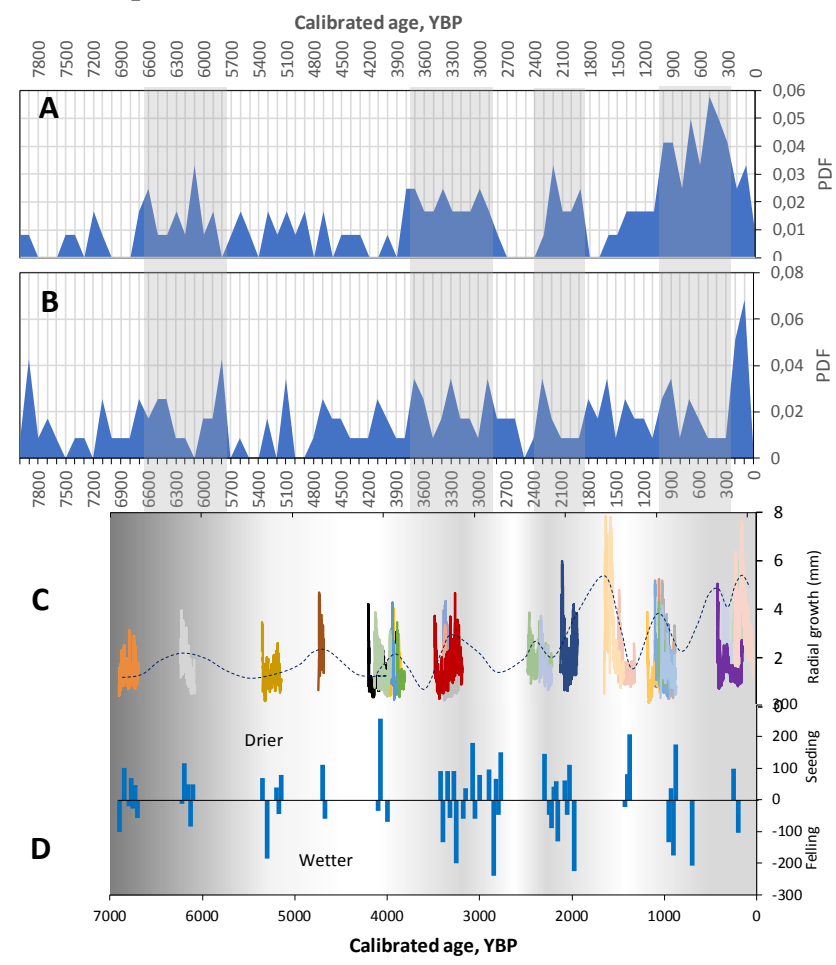

Fig.3. Probability density functions (PDFs) curves determined for the sedimentary units belonging to fluvial domain (A) and lacustrine domain (B) from Romania. Correlation of function parameters with radial growth for subfossil trunks originating from fluvial environment (C). Identification of humid periods (with potential for exceptional hydrological events) and dry periods on basis of dendrochronological sequences of subfossil trunks (D). The grey bends indicate the intervals with much intense hydro-geomorphological activity.

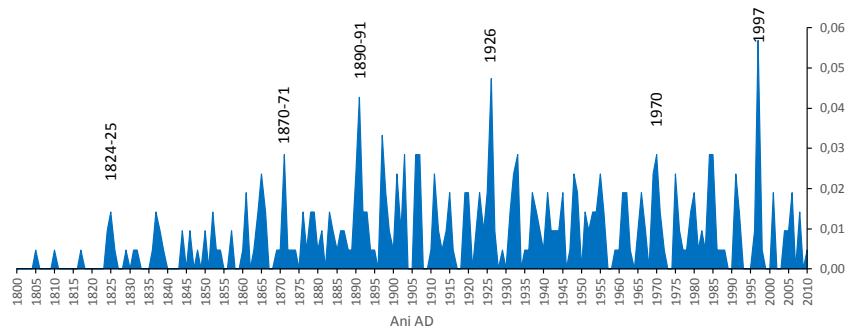

Fig.4. Years with excessive humidity during period 1800-2010, identified on basis of oak dendrochronological series of living trees from 29 stands distributed along Romania’s territory.

To note that the sedimentary sequences formed the basis of some time series were statistically addressed in the same manner of probability density functions (Fig. $3 B)$. Although in this case some specific groups of dated sedimentary sequences are observed, the peaks amplitude is much lower than in the fluvial domain. It is normal, considering that the lacustrine domain is much less turbulent, compared with the spatial discontinuities of the fluvial one.

In both temporal variations of PDFs several time intervals can be distinguished where the probability of achieving some hydro-geomorphological activity was higher, namely: 6600 - 5700; 3700-2900; 1900-2300; 1000-900 YBP. Over the last 700 years are visible the following intervals: 1200-1300AD, 1500-1600AD, 18001900AD. These intervals can also be identified at the level of subfossil trunks behavior, respectively, a large radial growth during humid periods (when the probability of registering exceptional hydrological events is higher than during dry periods when the trees have presented small radial growths) (Fig. $3 \mathrm{CDE}$ ).

The annual resolution offered by the dendrochronological investigations concerning the climatic elements (temperature, but especially precipitation) was the main reason for taking into consideration the information preserved in living trees with ages that reach the year 1800. The dendrochronological series processing allows the separation of pointer years when the tree has registered faithfully an excess of humidity or drought. In the followed context, we were interested by the years with humidity excess when the flood probability is maximum. The series of positive pointer years (Fig. 4) was addressed following the same technique, PDF analysis, and the result obtained completes in detail the information available for the last 200 years. Thus, the years with humidity excess identified, are: 1824-1825, 1870-71, 1890-91, 1926, 1970 and 1997 and were included in our final database.

The final conclusion of our paper is synthesized in Fig. 5. In this diagram was combined all the information compiled from our own researches and scientific publications regarding "changes data" [4] in fluvial and lacustrine environment sedimentation styles. The entire database $(n=404)$ was processed in the same manner using PDF analysis, for the last 12000 years. As the probability is higher, and the peaks of the variation curve are higher, in those intervals were focused more on exceptional events. On the contrary, a probability close to zero displays a reduced chance in that time interval to meet absolute dating data, respectively, changing sedimentation styles. On the diagram were indicated 15 peaks of the PDFs curve which indicate the time intervals with large hydrological events: 10300, 9800, 9200, 8500, 8000, 6790, 5650, 3750, 3300, 2850, 2350, 1500, 1300, 880,500 years BP.

The diagram from Fig. 4 is completed in its basal part with important events that have marked the sediment circuit on landforms surface. The large scale vegetation change at 10700 YBP (replacing the steppe with silvosteppe and forests [11], introduction of agriculture during early Neolithic, 8000-7500 YBP, the Stiucii Lake sequence revealed a continuous and consistent effect of human impact), [12] both with the already mentioned hydrological events, have determined optimum conditions for river channels (at least those on Siret and Somes sizes together with their important tributaries) changes of morphological style from braided to meandering.

In vertical plan, have been registered a general tendency of incision at that time being created the 4-5 m floodplain terraces. Climatic change reported around 4700 YBP determined an intensification of high magnitude hydrological events (as it is indicated also by the dendrochronology of subfossil trunks) that many reaches of river channels (especially those with Carpathian sedimentation source - Moldova Rivers being typical as regards this issue) were strongly filled with alluvium of 


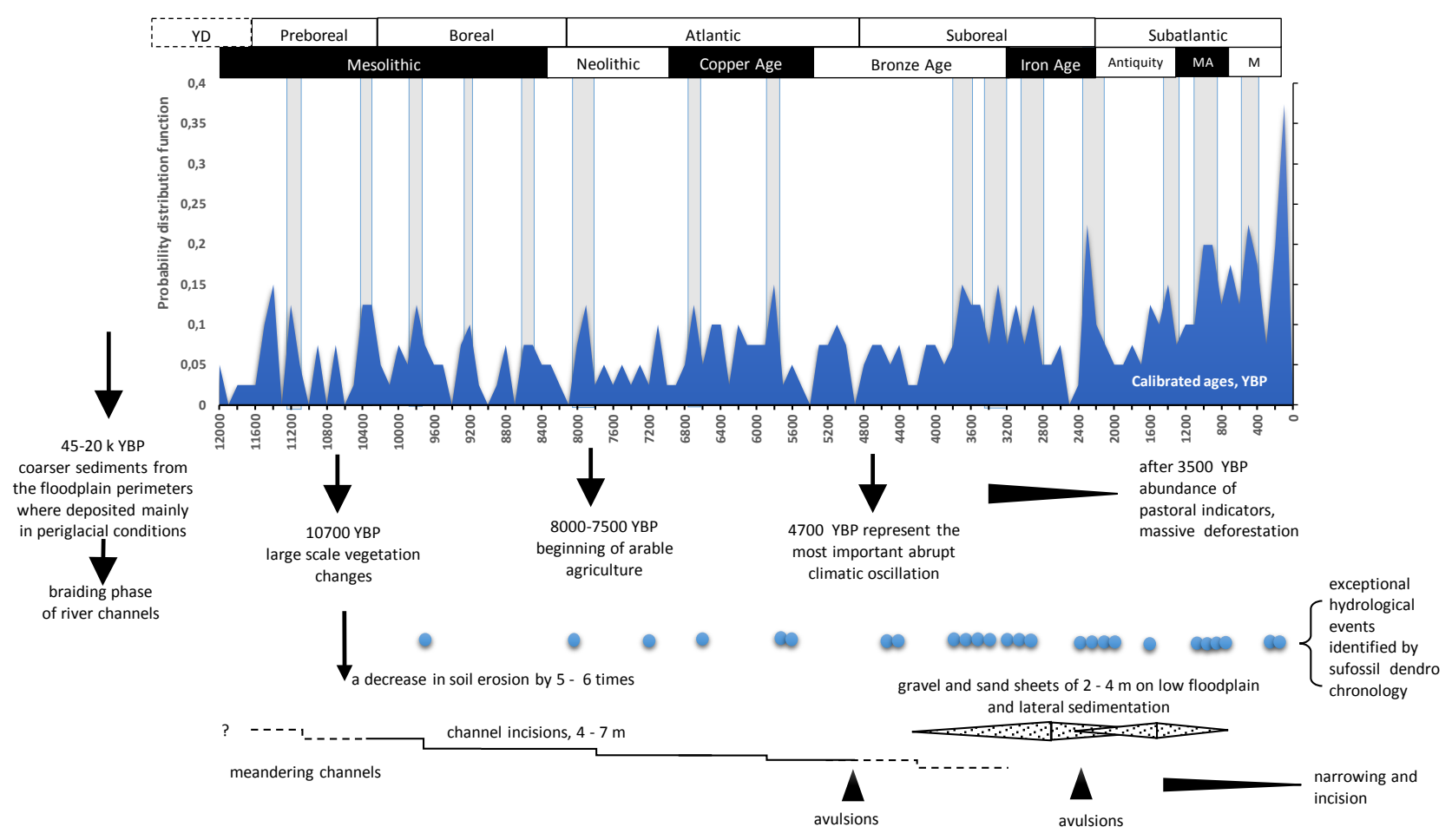

Fig. 5. Synthesis of sedimentation environments dynamics in Romania by using probability density functions. Interpreting the increased probability density with palaeo-environmental events reported for Holocene period (climatic oscillations, vegetation dynamics, human impact, palaeo-floods) The response reflected in river channel adjustments. Grey bands indicate the intervals with high probability that exceptional hydrogeomorphological events could occur

about 3-4 m thickness like a sheet of coarse gravel [13].

The meandered rivers, like Somes River located on the plain with the same name, have registered major course changes through the avulsion process (besides climatic factors, here intervened and the tectonic one [14]). Massive deforestations occurred after 3500 YBP (identified on basis of pastoral indexes from lacustrine sediments [11]) had its own contribution in expanding the alluvial or avulsion phenomenon on the rivers located in our geographical space.

The periods with major hydro-geomorphological events that we obtained, were compared with those reported for rivers in Central Europe (Tab. 1) and which followed the same methodological approach. It can be observed a very good concordance of the important peaks recorded for all three geographical regions. Four peaks (2850, 5650, 75008000 and 8500 YBP) were common in the databases for Germany, Poland and Romania; 11 from 15 peaks are common for the databases from Poland and Romania. Only for comparison, we have included the environmental evidence deduced on basis of a 12000-year proxy record in Stiucii Lake sediments located in Transylvanian Plain. We choose this example for its altitudinal position, very similar with one of the rivers for which we combined the data, thus, mitigating the influence of climatic natural setting.

In conclusion, for the first time in Romania a database containing 404 absolute dating data of some sedimentary units belonging to fluvial and lacustrine domains (the latter with direct connection to a fluvial network) was elaborated. The goal was to reconstruct the hydrologic and geomorphological activity phases of rivers. The working methods of data were based on a series of statistical tests and on obtaining the probability density functions curves. Fifteen phases of hydrogeomorphological activity were identified and have presented a high degree of synchronization (over 73\%) with the phases obtained in Poland and a medium one (over 47\%) with the phases determined for Germany.

TABLE I. PERIODS OF MAJOR FLOODING IN GERMANY, POLAND AND ROMANIA

\begin{tabular}{|c|c|c|c|}
\hline $\begin{array}{c}\text { Germany } \\
{[\mathbf{8}]}\end{array}$ & $\begin{array}{c}\text { Poland } \\
{[\mathbf{8}]}\end{array}$ & $\begin{array}{c}\text { Romania } \\
\text { (this study) }\end{array}$ & $\begin{array}{c}\text { Lake Ştiucii } \\
\text { proxy record } \\
{[\mathbf{1 2}]}\end{array}$ \\
\hline & $\mathbf{5 0 0}$ & $\mathbf{5 0 0}$ & $500-750$ \\
\hline $\mathbf{8 8 0}$ & $\mathbf{8 8 0}$ & \\
\hline $\mathbf{1 2 7 5}$ & & $\mathbf{1 3 0 0}$ & \\
\hline $\mathbf{2 3 2 5}$ & $\mathbf{1 5 0 0}$ & $\mathbf{1 5 0 0}$ & $1450-1550$ \\
\hline $\mathbf{2 8 2 0}$ & $\mathbf{2 8 5 0}$ & $\mathbf{2 3 5 0}$ & $1900-2200$ \\
\hline $\mathbf{3 3 5 0}$ & & $\mathbf{2 8 5 0}$ & $2600-2850$ \\
\hline & $\mathbf{3 7 0 0}$ & $\mathbf{3 3 0 0}$ & $3300-3600$ \\
\hline 4250 & & & $3950-4250$ \\
\hline & 4850 & & $4750-5000$ \\
\hline $\mathbf{5 6 9 0}$ & $\mathbf{5 6 0 0}$ & $\mathbf{5 6 5 0}$ & $5650-5900$ \\
\hline & $\mathbf{6 4 0 0}$ & $\mathbf{6 7 9 0}$ & $6750-7100$ \\
\hline $\mathbf{7 5 2 5}$ & $\mathbf{7 7 0 0}$ & $\mathbf{8 0 0 0}$ & $7900-8200$ \\
\hline $\mathbf{8 2 5 0}$ & $\mathbf{8 4 0 0}$ & $\mathbf{8 5 0 0}$ & \\
\hline $\mathbf{9 0 5 0}$ & & $\mathbf{9 2 0 0}$ & $9400-9550$ \\
\hline & $\mathbf{9 6 0 0}$ & $\mathbf{9 8 0 0}$ & \\
\hline & $\mathbf{1 0 2 0 0}$ & $\mathbf{1 0 3 0 0}$ & $10200-10500$ \\
\hline
\end{tabular}

\section{ACKNOWLEDGMENT}

The research was supported by a grant of the Romanian National Authority for Scientific Research and Innovation, CNCS - UEFISCDI, project number PN-II-RU-TE-20144-0855 "Reconstruction of Late Holocene History of 
Romanian rivers based on geomorphological and dendrochronological interpretation of subfossil trunks”.

\section{REFERENCES}

[1] M.G. Macklin and J. Lewin, "River sediments, great floods and centennial-scale Holocene climate change”, J. Quat. Sci., vol. 18, pp. 101-105, 2003.

[2] J. Lewin, M.G. Macklin, and E. Johnstone, "Interpreting alluvia archives: sedimentological factors in the British Holocene fluvial record”, Quat. Sci. Rev., vol. 24, pp. 1873-1889, 2005

[3] M.G. Macklin, G. Benito, K.J. Gregory, E. Johnstone, J. Lewin, D.J. Michezyńska, R. Soja, L. Starkel, and V.R. Thorndycraft, "Past hydrological events reflected in the Holocene fluvial record of Europe”, Catena, vol. 66, pp. 145-154, 2016.

[4] A.F. Jones, M.G. Macklin, and G. Benito, "Meta-analysis of Holocene fluvial sedimentary archives: A methodological primer", Catena, vol. 130, pp. 3-12, 2015.

[5] V.R. Thorndycraft and G. Benito, "The Holocene fluvial chronology of Spain: evidence from a newly compiled radiocarbon database”, Quat. Sci. Rev., vol. 25, pp. 223-234, 2006.

[6] T. Hoffmann, A. Lang, and R. Dikau,"Holocene river activity: analysing 14C-dated fluvial and colluvial sediments from Germany”, Quat. Sci. Rev., vol. 27, pp. 2031-2040, 2008.

[7] L. Starkel, R. Soja, and D. Michczynska, "Past hydrological events reflected in Holocene history of Polish rivers”, Catena, vol. 66, pp. 24-33, 2006.

[8] L. Starkel, D. Michczyńska, M. Krąpiec, W. Margielewski, D Nalepka, and A. Pazdur, "Progress in the Holocene chronoclimatostratigraphy of Polish territory”, Geochronometria, vol. 40, no. 1, pp. 1-21, 2012.

[9] A. Perșoiu, "Climate Evolution during the Late Glacial and the Holocene”, in Landform Dynamics and Evolution in Romania, M. Rădoane and A. Vespremeanu-Stroe, Eds., Springer, 2017, pp. 5766.
[10] M.G. Macklin, J. Lewin, and J.C. Woodward, "The fluvial record of climate change”, Phil. Trans. R. Soc. A, vol. 370, pp. 2143 2172, 2012.

[11] A. Feurdean and I. Tanțău, "The Evolution of Vegetation from the Last Glacial Maximum Until the Present”, in Landform Dynamics and Evolution in Romania, M. Rădoane and A. VespremeanuStroe, Eds., Springer, 2017, pp. 67-83.

[12] A. Feurdean, J. Liakka, B. Vannière, E. Marinova, S.M Hutchinson, V. Mosburgger, and T. Hickler, "12,000-Years of fire regime drivers in the lowlands of Transylvania (Central-Eastern Europe): a data-model approach”, Quaternary Science Reviews, vol. 81, pp. 48-61, 2013.

[13] M. Rădoane, C. Nechita, F. Chiriloaei, N. Rădoane, I. Popa, C Roibu, and D. Robu, "Late Holocene fluvial activities and relations with subfossil trunks: case study Moldova and Siret Rivers, Romania”, Geomorphology, vol. 239, pp. 142-159, 2015.

[14] I. Perşoiu, D. Robu, M. Rădoane, A. Perșoiu, B. Niga, F. Chiriloei, and N. Rădoane, in prep. "Late Glacial - Holocene subsidence in the NE Pannonian Basin (Ecedeea Plain) and its influence on fluvial drainage patterns”.

[15] I. Perșoiu and M. Rădoane, "Fluvial activity during the Holocene”, in Landform Dynamics and Evolution in Romania, M. Rădoane and A. Vespremeanu-Stroe, Eds., Springer, 2017.pp. 469-488. 


\title{
The evolution of the area between Valea Chinteni and Valea Calda after the works done so as to prevent the soil erosion
}

\author{
Violeta-Elena Retegan \\ Department of Geography \\ Cluj-Napoca, Romania \\ violetaretegan@yahoo.it
}

\begin{abstract}
The area studied is situated on the left hill of the Somesul Mic river, along Cluj -Napoca municipality and is deliminated at north and east by the watershed area, which separates the hydrografic subbasin Valea Calda, at south of agricultural road which separates the hill of the meadow Somesul Mic and at west the border of the orchard IAS, The Agricultural State Enterprise Cluj.The area is called Sfantul Gheorghe Hill the omonim peak at the east margin, and Tigla Hill, at east. In 1986 The Institute of Studies and Projects for Landing Improvements applied a plan for preventing the soil erosion on a surface of 600 hectares in the limits mentioned [1]. Among these, 300 hectares represented the arranging of terraces, 200 hectares the arranging the slid lands and $\mathbf{1 0 0}$ hectares of drainages on hills. The works executions of preventing the soil erosion wanted as a finallity the reductions of soil yearly looses, the possibility of applying of some suitable agrotechniques in fruit trees plantations which were going to establish. The arranging of slid landings was made by modelling, the removal moisture excess, terracing, grassing or planting and had the purpose to reduce in the economic circuit many land surfaces. The removal of water excess through drainages was accomplished for a proper development of the future fruit trees plantations, as well as to offer the possibility of executation by fruit trees agrotechnique, all year round. Firstly, the purpose of this study is to analyse the temporary evolution on a period of 30 years, the work efficiency of arranging the slope arranged in 1986. The estimation of work efficiency in that moment was made through a comparative analyse, morfometric and morfologic of land slidings and of erosion forms in deepth on the hills. Secondly, the study analyzes the vulnerability of the elements exposed to risk, at landslidings from this complex, especially of the dwellings and of those with a public destination, of the road infrastructure and of the agricultural lands.
\end{abstract}

Keywords - territory arranging; soil erosion; landslidings; terraces; modelling; vulnerability; torrents

\section{PREMISES}

The study is based on the following premises: the south slope geomorfology of the hill Sfantu Gheorghe was deeply studied along the time, as the bibliographic sources show $[2,3,4] ; 30$ years ago, the territories destinations of this complex is predominant agricultural and the territory arranging plans had especially measures destinated to agricultural arrangements.; In the last years, it has been shown a fast expansion of Cluj-Napoca municipal [5], inclusive on the north hill of Somesul Mic River, at the base of the hill towards the interfluves, as well as along the hill base, towards the eastern outskirts of the city.

\section{QUESTIONS}

The questions raised are: how the landslidings evolved and how the hill evolved after the arrangement made in 1986; how many of the elements built are placed in areas with an acceptable risk and how many are situated in areas with high risk from the point of view of hills stability $[6,7$, 8].

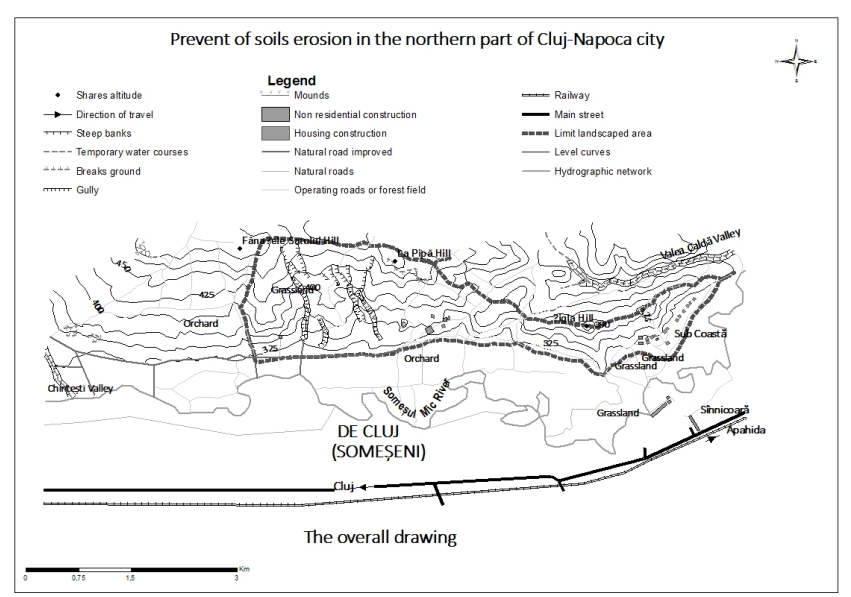

Fig. 1. Prevent of soils erosion in the northern part of Cluj-Napoca, 1986 


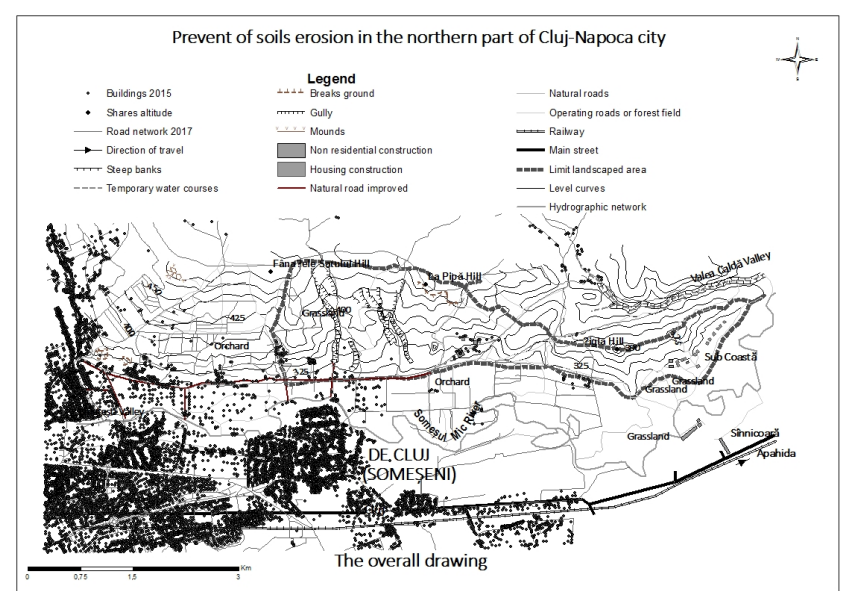

Fig. 2. Prevent of soils erosion in the northern part of Cluj-Napoca, 2015

\section{REFERENCES}

[1] „Preventing the soil erosin on the northern part of Cluj-Napoca municipality”, Project no.6855 of the Institute of Studies and Projects for Landing Improvements within Ministry of Agriculture, The general direction of land reclamation end economic agricultural buiding, Cluj-Napoca, 1986, unpublished.

[2] T. Morariu and I.Mac, , Geomorphological regionalization of the territory of Cluj and surroundings”, Studia Universitatis „BabeşBolyai”, series Geology-Geography, vol.2, p. 75-88, 1967.

[3] V. Surdeanu, D. Goțiu, I. Rus and A. Crețu, „Geomorphology applied in the urban area of Cluj-Napoca municipality, Journal of geomorphology, vol. 8, pp. 25-34, 2006.

[4] S.L. Poszet, „Applied geomorphology study in urban area ClujNapoca”, PhD thesis, 2011.

[5] I. Hărănguș, „,The accessibility of Cluj-Napoca to public transport”, 14th National Student Scientific Session, U.T. Press, Cluj-Napoca, 2015, p.526-532.

[6] D. Goțiu, „Risk geomorphological processes in Hațeg Land”, PhD, 2007.

[7] D. Goțiu and V. Surdeanu, „Fundamental concepts in the study of natural hazards”, Cluj University Press, Cluj-Napoca, 2007.

[8] M. Licurici, O. Ionuș, L. Popescu, A. Vlăduț, S. Boengiu and D. Simulescu, „Assessment and reduction of natural and technological hazards”, Universitaria Press, Craiova, 2013. 


\title{
Coastal storms risk assessment for Mamaia and Eforie barriers
}

\author{
Mădălina Ristea, Florin Tătui \\ Faculty of Geography \\ University of Bucharest \\ Bucharest, Romania
}

\begin{abstract}
The level of damage for Mamaia and Eforie Barriers shows that in a risk assessment to coastal storms, more important than the inundation limit is, in fact, the density of elements (buildings, roads, etc.) that can be affected.
\end{abstract}

Keywords - coastal storms; inundation scenarios; risk assessment

\section{INTRODUCTION}

Storms are a major threat for the large number of people living in coastal areas. The rapid climate change has led to intensified coastal storms throughout the world, resulting in extreme damage to households and even loss of human lives. This is the main reason for the increasing interest in risk assessment and disaster risk reduction measures in the last decade.

This paper aims to assess the risk to coastal storms for two vulnerable sectors of the Romanian Black Sea coast Mamaia and Eforie barriers. These sectors represent very important touristic areas, with valuable infrastructure, which can be highly affected in the event of a major storm. We focused our analysis on the risk of buildings and infrastructure, excluding the potential loss of human lives because we considered that a major storm is most likely to occur in the active season (winter season), when the number of tourists on the two barriers is low.

\section{Methodology}

The methodology is based on three scenarios: the impact of low storms (significant wave height of $2.5 \mathrm{~m}$ ), severe storms (significant wave height of $5 \mathrm{~m}$ ) and extreme storms (significant wave height of $7 \mathrm{~m}$ ). We calculated the maximum horizontal distance that storm waves can reach on the beach in order to establish the inundation limits (computed by the ratio between wave run-up and foreshore slope) for each scenario.

First, we computed wave run-up level (measured vertically from the waterline) for all three scenarios using the approach proposed in [1]:

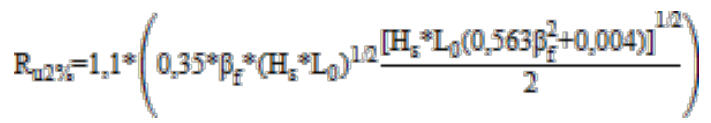

where $\beta_{\mathrm{f}}$ is the foreshore beach slope defined over the area of significant swash activity, $\mathrm{H}_{\mathrm{s}}$ is the significant wave height and $L_{0}$ is the offshore wave length, which can be expressed as $\mathrm{L}_{0}=\mathrm{gT}^{2} / 2 \pi$. In order to determine the horizontal distance of wave run-up on the beach, we used the equation proposed in [2]:

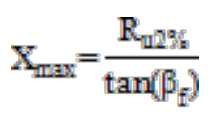

where $R_{u 2 \%}$ is the $2 \%$ exceedance level for run-up peaks on natural beaches and $\beta_{\mathrm{f}}$ is the foreshore beach slope.

For determining the water levels in the point of maximum run-up and of flow velocities on the beach we made a medium profile for each barrier, by interpolating 15 different profiles for Mamaia Barrier and 4 for Eforie Barrier. After that we established the highest point on each beach in order to compute the overwash extension. The water level at the top of the above mentioned point can be obtained using the approach proposed in [3]:

$$
\mathrm{h}=\frac{\tan \beta_{\mathrm{w}} \mathrm{x}_{\mathrm{C}}}{\mathrm{x}_{\mathrm{R}} \cos \beta}\left(\mathrm{x}_{\mathrm{R}}-\mathrm{x}_{\mathrm{C}}\right)
$$

where: $X_{R}$ is the horizontal distance of wave run-up on the beach (the same as $X_{\max }$ ), $X_{c}$ is the distance from the still water line to the highest point on the beach, $\beta$ is the beach slope and $\tan \beta_{\mathrm{w}}$ is a constant $(0,035)$.

The flow velocities were computed using the equation proposed in [4]:

$$
\mathrm{u}=0,66 \sqrt{\mathrm{gh}}
$$

where: $\mathrm{g}$ is the gravitational acceleration and $\mathrm{h}$ is the water level at the highest point on the beach.

Knowing the two values, water level and velocity, we were able to determine the inundation rate for each barrier (Tab. I). 
TABLE I. INUNDATION RATES FOR MAMAIA AND EFORIE BARRIERS

\begin{tabular}{|c|c|c|c|}
\hline & $\begin{array}{c}\text { Water } \\
\text { level/Depth } \\
\text { (m) }\end{array}$ & $\begin{array}{c}\text { Velocity } \\
\text { (m/s) }\end{array}$ & $\begin{array}{c}\text { Depth-Velocity } \\
\text { Product }\left(\mathbf{m}^{2} / \mathbf{s}\right)\end{array}$ \\
\hline $\begin{array}{c}\text { Mamaia } \\
\text { Barrier }\end{array}$ & 1.081 & 2,148 & 2.323 \\
\hline $\begin{array}{c}\text { Eforie } \\
\text { Barrier }\end{array}$ & 1.890 & 2.841 & 5.370 \\
\hline
\end{tabular}

Based on this methodology and on the results, we could assess the risk for each building and for infrastructure inside the inundation limits of each scenario. This way, we have obtained a comprehensive database containing information like: type of building, type of use, year of construction, surface, materials they were made of, market value, etc.

\section{RESULTS}

The inundation limits range between approximately 25 $\mathrm{m}$ for low storms (26.53 m for Eforie Barrier and $24.28 \mathrm{~m}$ for Mamaia Barrier), $90 \mathrm{~m}$ for severe storms (90.75 m for Eforie Barrier and $88.01 \mathrm{~m}$ for Mamaia Barrier) and $190 \mathrm{~m}$ for extreme storms (193.87 m for Eforie and $194.73 \mathrm{~m}$ for Mamaia) (Fig. 1 and 2). Taking into consideration the good correlation between risk degree and barrier width, for Eforie Barrier, characterized by lower widths, the inundation limit for extreme storms exceeds in some places its width, affecting not only all the buildings, but also important infrastructure that connects the northern part of the coast with the southern one. Being almost double in size, Mamaia Barrier does not experience the same problems, but the high density of buildings increases its risk. In the case of low storms, only unanchored wooden structures could be affected, while for severe storms they would be totally damaged. Anchored wooden structures would only be partially damaged during severe storms and totally destroyed in case of an extreme storm, while concrete and brick structures could be partially affected on the ground floor in the worst case scenario (an extreme storm) (Table II.).

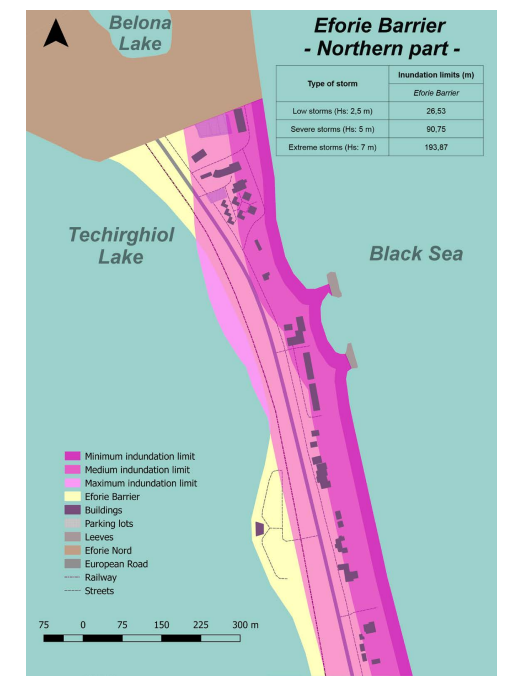

Fig.1. The inundation limits on Eforie Barrier
For the risk assessment, we only considered the limit for extreme storms for both barriers. Because the value per square meter is different along Mamaia Barrier, we had to divide it in 5 areas: area A1 - situated between Tăbăcărie Lake and Melody Bar, A2 - between Melody Bar and Rex Hotel, B1 - between Rex Hotel and “At the Barrels”, B2 between "At the Barrels" and Summerland rezidential area and B3 - between Summerland and the northern limit of the barrier [5] (B3 area - Fig.2). Overlaying the maximum inundation limit over the buildings we were able to extract the ones that could be inundated during an extreme storm. A number of 218 buildings on Mamaia Barrier and 50 on Eforie Barrier could be inundared during a major event (Table III.). After calculating a mean area for the buildings and extracting the mean values per square meter from [5], we could determine the mean value of the losses on the two barriers: 108.382.802 € for Mamaia Barrier and 7.582.700 € for Eforie. The latter is crossed by a road and a railway of national importance, both affected by the event, with a value of $13.780 .840 €$ (of which 7.840.000 $€$ for $2 \mathrm{~km}$ of road and $5.940 .840 €$ for $1.597 \mathrm{~km}$ of railway) according to [6]. This means that the value of losses for Eforie Barrier is 21.363.540 $€$, for both buildings and infrastructure.

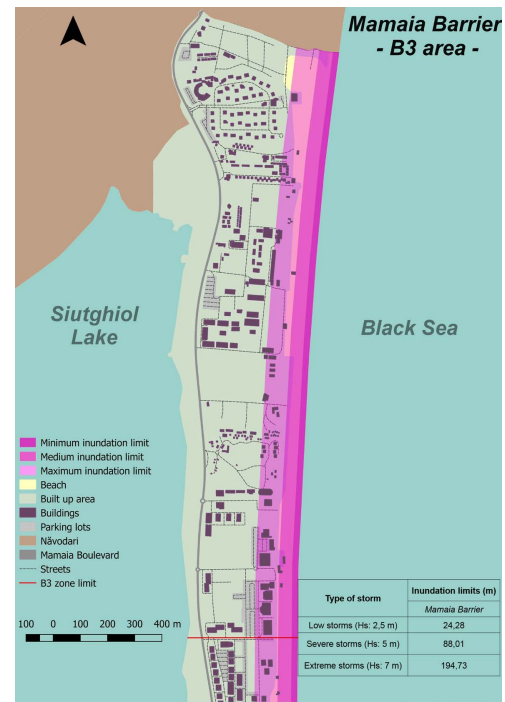

Fig. 2. The inundation limits on Mamaia Barrier

\section{CONCLUSIONS}

Even though, at first all tend to assume that, because the limit of Eforie Barrier is exceeded, the risk should be higher, in fact, the most important variable is the percentage of buildings or things that could be affected. Although the losses are much smaller than on Mamaia Barrier, the disruption between the northern and the southern part of the coastal area deriving from the inundation of the road and the railway, affects not only the barrier, but also all the communities located south. This 
type of assessment can be a starting point for disaster risk reduction measures and better management strategies that can diminish the potential losses on Mamaia and Eforie barriers in case of severe and extreme storms. Another gain from risk assessment analysis should be the awareness of all the problems that coastal communities will have to face due to climate change.

TABLE II ${ }^{\mathrm{a}}$. DEGREE OF DAMAGE BASED ON THE INUNDATION RATES

\begin{tabular}{|c|c|c|c|}
\hline & \multicolumn{3}{|c|}{ Depth-Velocity Product (ms) } \\
\hline House type & Inundation & Partial damage & Total damage \\
\hline Wood - Framed: Unanchored & $0-1,99$ & $2-2,99$ & $3->7$ \\
\hline Wood - Framed: Anchored & $0-2,99$ & $3-6,99$ & $>7$ \\
\hline Masonry, concrete and brick & $0-2,99$ & $3-6,99($ if $\mathrm{v}$ is also $\geq 2 \mathrm{~m} / \mathrm{s})$ & $>7$ (if $\mathrm{v}$ is also $\geq 2 \mathrm{~m} / \mathrm{s})$ \\
\hline
\end{tabular}

aTable modified after [7]

TABLE III. POTENTIAL LOSSES PRODUCED BY AN EXTREME STORM ON THE TWO BARRIERS

\begin{tabular}{|c|c|c|c|c|c|c|}
\hline & \multicolumn{7}{|c|}{ Mamaia Barrier } & \multirow{2}{*}{ Eforie Barrier } \\
\cline { 2 - 7 } & A1 area & A2 area & B1 area & B2 area & B3 area & \\
\hline No. of buildings affected & 61 & 42 & 21 & 21 & 73 & 50 \\
\hline Mean area per building (m) & 1.121 & 899 & 1.955 & 598 & 388 & 382 \\
\hline Mean value per m ${ }^{2}(€)$ & 578 & 616 & 568 & 554 & 541 & 397 \\
\hline Mean price per building (€) & 647.938 & 553.784 & 1.110 .440 & 331.292 & 209.908 & 151.654 \\
\hline Mean price per area (€) & 39.524 .218 & 23.258 .928 & 23.319 .240 & 6.957 .132 & 15.323 .284 & 7.582 .700 \\
\hline
\end{tabular}

\section{REFERENCES}

[1] H.F. Stockdon, R.A. Holman, P.A. Howd, and A.H. Sallenger, "Empirical parameterization of setup, swash and run-up", Coastal Engineering, vol. 53, no. 7, pp. 573-588, 2006.

[2] G. Di Paola, P.P.C. Aucelli, G. Benassai, and G. Rodriguez, "Coastal vulnerability to wave storms of Sele littoral plain (southern Italy)”, Natural Hazards, vol. 71, pp. 1795-1819, 2014.

[3] H. Schuettrumpf and H. Oumeraci, "Layer thicknesses and velocities of wave overtopping flow at seadikes", Coastal Engineering, vol. 52, pp. 473-495, 2005.
[4] H. Matsutomi, K. Okamoto, and K. Harada, "Inundation flow velocity of tsunami on land and its practical use”, Coastal Engineering Proceedings, vol.2, pp. 860-870, 2010.

[5] Rosa Trade International, "Market research on recorded minimum values of property in Constanța County," 2016.

[6] Ministry of Transport, “General Master Plan for Transport,” 2015.

[7] T. Karvonen, A. Hepojoki, H.K. Huhta, and A. Louhio, “The use of physical models in dam-break analysis,” RESCDAM Final Report, Helsinki University, 2000. 


\title{
Geomorphological evolution of coastal landslides in Malta: integration of terrestrial and marine datasets
}

\author{
Mauro Soldati, Mariacristina Prampolini, Vittoria Vandelli \\ University of Modena and Reggio Emilia \\ Department of Chemical and Geological Sciences \\ Modena, Italy
}

\begin{abstract}
The paper shows the main results of multidisciplinary research carried out in the Island of Malta aiming at the integration of terrestrial and marine datasets. Identification, mapping, monitoring and dating of landsides, including submerged ones, have enabled to define a time frame for the development of landslides and to reconstruct the geomorphological evolution of the investigated areas. This has provided useful means for landslide susceptibility and hazard mapping, which is crucial for north-west coast of Malta.
\end{abstract}

Keywords - coastal geomorphology; landslides; dating; Malta; Mediterranean Sea

\section{INTRODUCTION}

Coastal areas are often densely populated and heavily urbanized mainly due to tourist and recreational activities. For this reason recognition of active coastal processes and the understanding of past and present geomorphological evolution is crucial in hazard assessment and risk mitigation.

This paper shows the results of research carried out within the framework of projects funded by the EUR-OPA Major Hazards Agreement (Council of Europe) aiming at providing national and regional administrations with methodologies for geomorphological hazard assessment in coastal areas. Integrated geomorphological mapping of emerged and submerged areas of the north-west coast of the Island of Malta (central Mediterranean Sea) was carried out, with special attention to gravity-induced landforms and processes, in order to achieve baseline datasets to be used for landslide susceptibility mapping and subsequently for hazard and risk assessments.

\section{GeOlOGICAL AND GEOMORFOLOGICAL SETting}

From a geological viewpoint, the Island of Malta is characterized by a marine sedimentary succession made up of different lithotypes mainly ascribable to limestones, marls and clays ranging in age from the Upper Oligocene to the Upper Miocene [1]. In the north-western sector of Malta, the outcropping rocks mainly belong to the Blue Clay Formation, consisting of grey soft marls, and the overlying Upper Coralline Limestone Formation, consisting of grey hard limestones (Fig. 1). The Blue Clays outcrop in correspondence of slopes locally terraced inland and reaching the sea along a widespread coastal stretch.
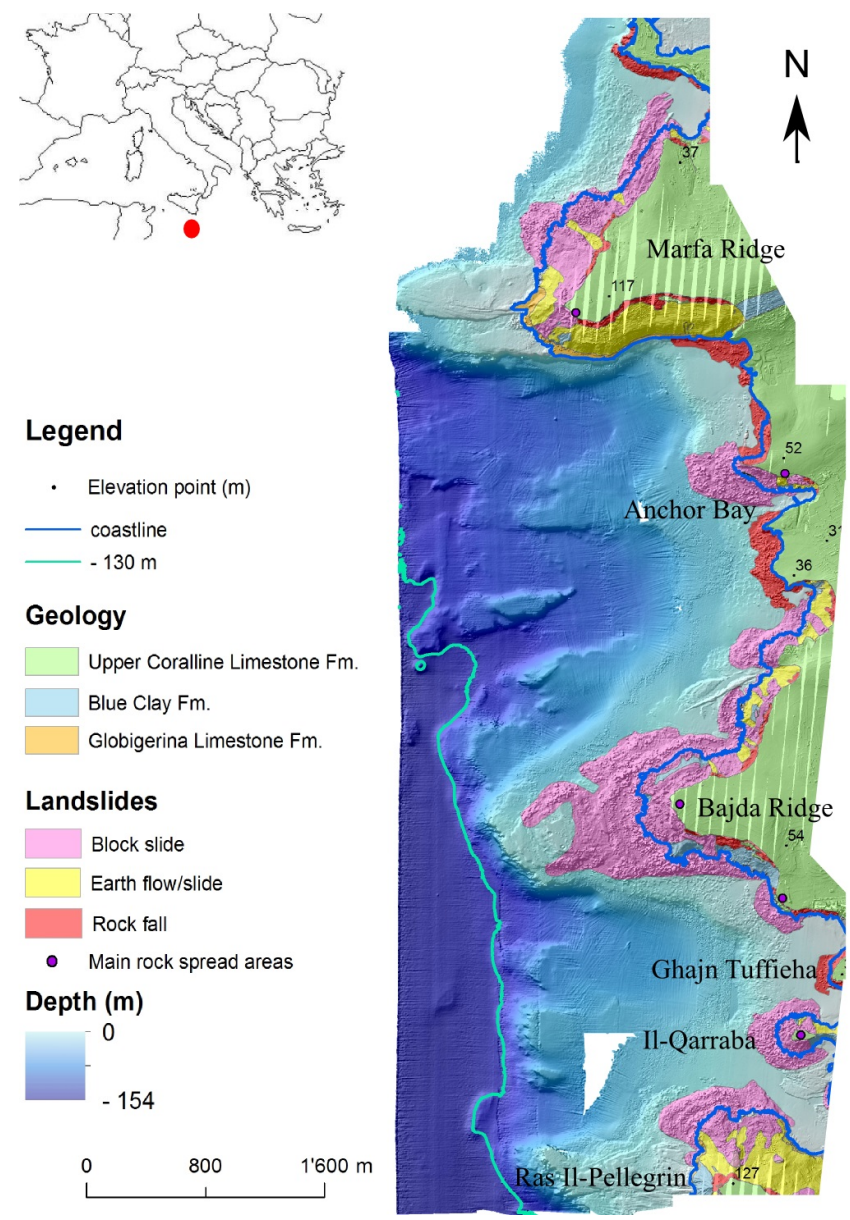

Fig. 1. Location of the Maltese archipelago and distribution of landslides along the NW coast of the Island of Malta.

From a tectonic perspective, a WSW-ENE oriented fault system determines a horst-and-graben structure deeply influencing the topography and the coastal 
morphology of the investigated area. The tectonic setting and the overlapping of hard and fragile limestones over visco-plastic terrains (marls and clays) favours the development of impressive rock spreading and block sliding phenomena which are widespread in particular at Ghajn Tuffieha Bay (Fig. 2), Ras Il-Wahx and Marfa Ridge.

Block slides are the most diffuse type of landslide along the north-west coast of Malta and they characterize both the emerged and submerged geomorphological landscape. Block-slide accumulations are associated with rock falls and rock topples occurring at the edges of the limestone plateaus, whose detachment is favored by persistent fissures and cracks of tectonic origin enlarged by rock spreading [2, 3]. In addition, earth flows and earth slides are frequent in the clayey slopes, as well as gully erosion.

\section{EMERGED AND SUBMERGED LANDSLIDE FEATURES}

In the first research stages, emerged coastal landslides were identified, mapped [4] and monitored [3] along the north-west coast of the Island of Malta. Further on, the research moved underwater to investigate the continental shelf. A multibeam survey coupled with an airborne bathymetric LiDAR survey were carried out allowing to produce a continuous high-resolution (2 m) Digital Elevation Model (DEM) of coastal and submarine areas.

The coupling between terrestrial and marine datasets showed that mass-movement deposits have a clear continuity above and below the sea level (Fig. 3). In correspondence of coastal stretches affected by block
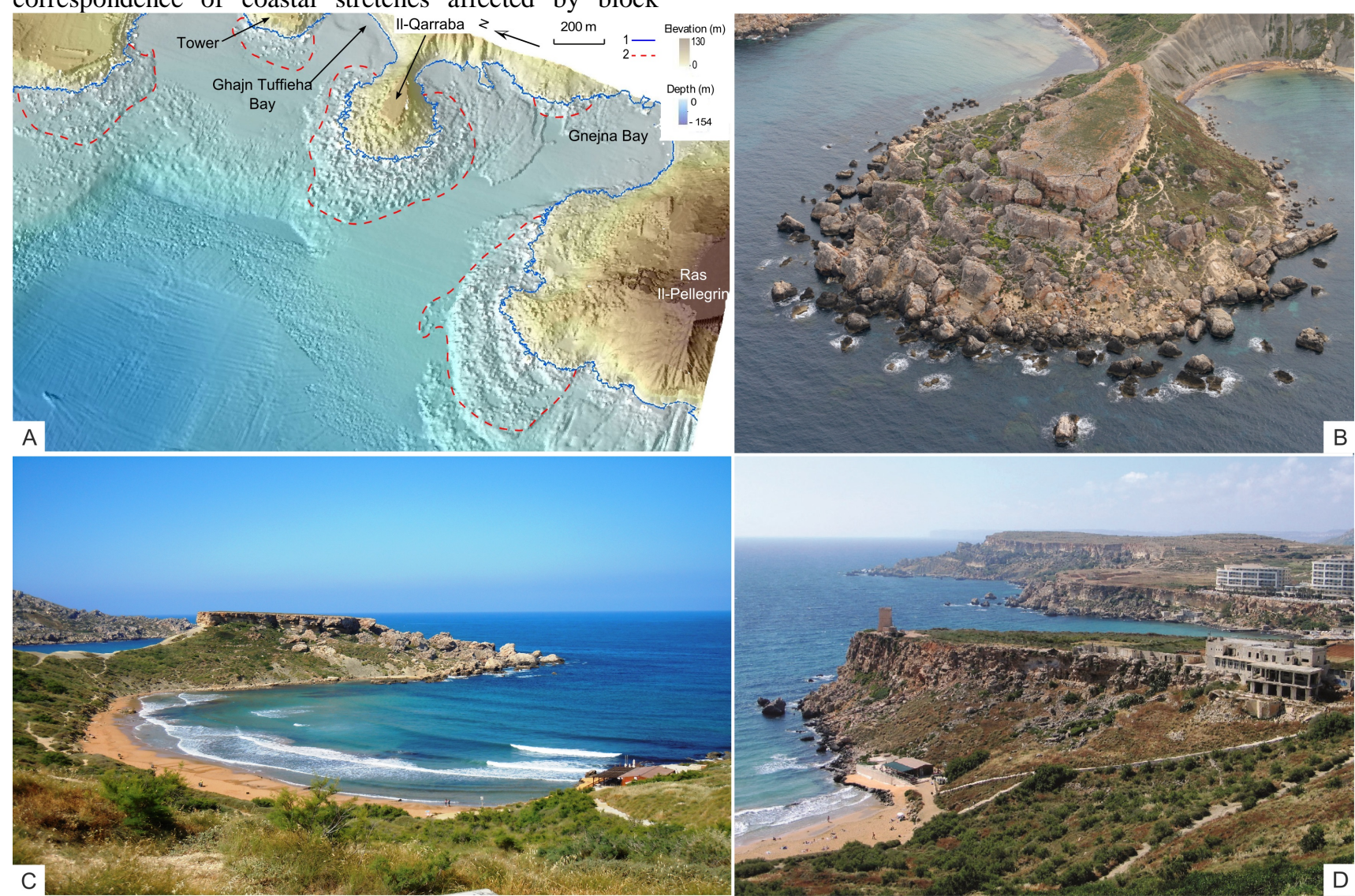

Fig. 2. Coastal stretch between Ghajn Tuffieha Bay and Ras Il-Pellegrin promontory, north-west coast of Malta. A) DTM of the area and surrounding seafloor; 1) present coastline; 2) outline of the submarine landslide deposit; B) Aerial view of Il-Qarraba plateau affected by block slides; C) IlQarraba peninsula and Ghajn Tuffieha Bay seen from the north; D) Ghajn Tuffieha northern side seen from the south 
As a result of CRE dating, a sample collected close to the limestone cliff edge at Anchor Bay provided a date of ca. $21 \mathrm{kyr}$, which was the oldest date achieved for the north-west coast. It should be noted that time the sea level was about $130 \mathrm{~m}$ lower than at present which means that the detachment occurred in complete subaerial conditions. According to other dating, successive displacements took place up to $7.4 \mathrm{kyr}$ ago, that is in a period when the sea level had already reached the landslide accumulations, possibly influencing their development. For further information on landslide dating along the north-west coast of Malta, see [8].

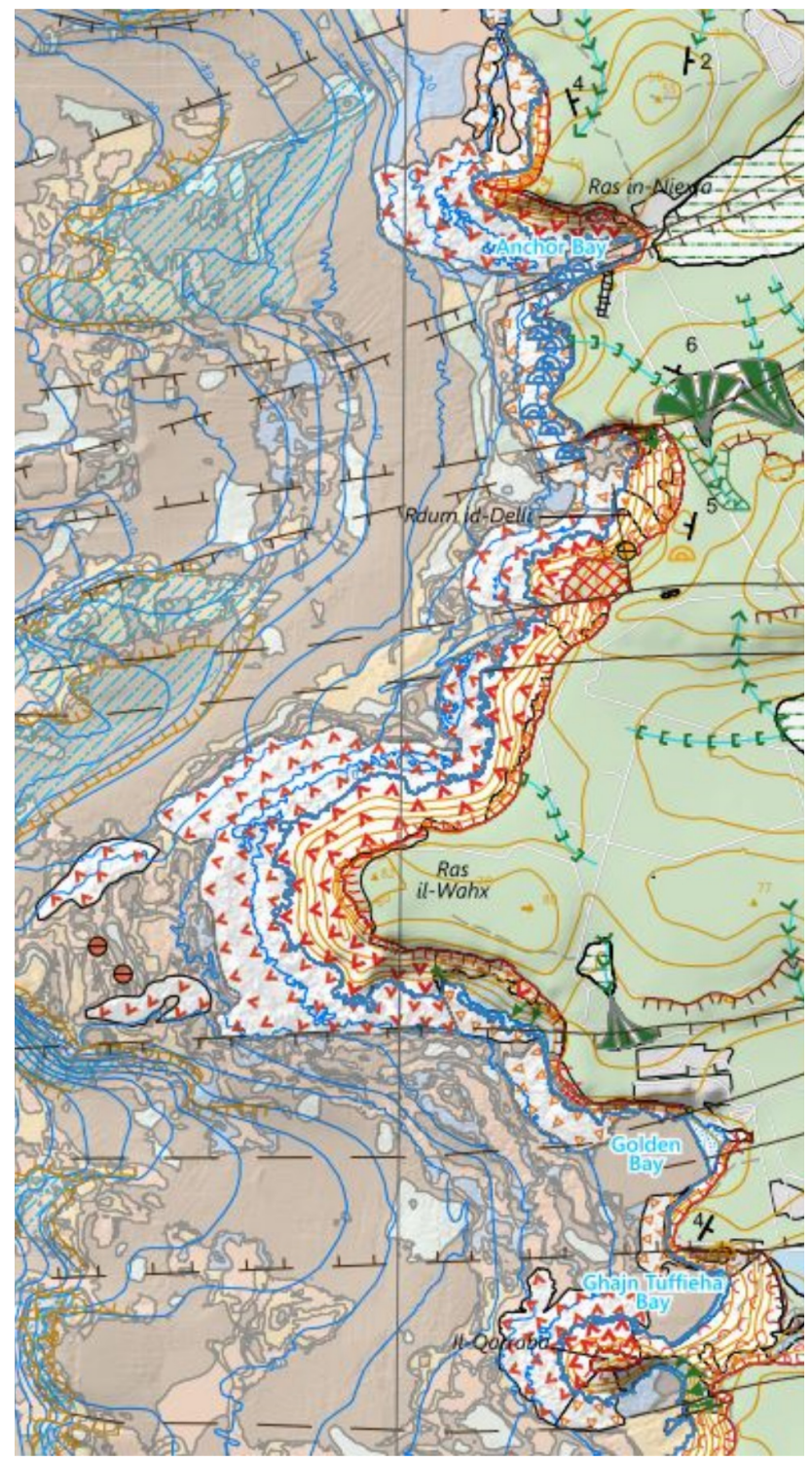

Fig. 3. Sketch of the geomorphological map of emerged and submerged areas of north-west Malta, from Anchor Bay to the north and Il-Qarraba promontory to the south. The bold blue line corresponds to the present coastline. Modified after [6].

\section{GEOMORPHOLOGICAL EVOLUTION}

Most of the geomorphological features identified on the seafloor - including landslide deposits - are terrestrial in origin and were emerged during the Last Glacial Maximum (LGM), when the sea level was about $130 \mathrm{~m}$ lower than at present $[9,10]$. The CRE dating confirmed that also the block slides, which largely characterize the north-west coast of the Island of Malta, developed in subaerial conditions, whilst their accumulations were partially submerged and hidden by the sea during by the post-glacial marine transgression [8].

The block slides possibly sped up when the sea level reached the landslide deposits during post-glacial sea level rise. CRE dating showed that older detachment events are located more inland. Therefore, the block-slide deposits observable nowadays, both on land and on the seafloor, may have developed as a result of a first-time failure involving large portions of the slopes. Secondary movements are likely to have occurred later on in time also under the influence of the sea action, as a consequence of progressive sea level rise. Investigations on mass movement kinematics are in progress aiming at modelling block-slide evolution through time.

\section{CONCLUSIONS}

The integration of terrestrial and submarine datasets represents a novel approach for the reconstruction of the geomorphological evolution of coastal areas, which is crucial in Mediterranean areas also in consideration of the ongoing climatic changes. The knowledge of spatial and temporal distribution of landslides has provided the means for correct and reliable susceptibility and hazard assessments, which are of paramount importance in tourist areas, such as the north-west coast of Malta $[11,12]$.

\section{ACKNOWLEDGMENTS}

This research was part of the Projects "Coupling terrestrial and marine datasets for coastal hazard assessment \& risk reduction in changing environments" (2014-15) and "Developing geomorphological mapping skills and datasets in anticipation of subsequent susceptibility, vulnerability, hazard and risk mapping" (2016-17) funded by the EUR-OPA Major Hazards Agreement of the Council of Europe (responsible: M. Soldati). We acknowledge the contribution of Timothy Barrows in CRE dating at the University of Exeter.

\section{REFERENCES}

[1] N. Baldassini and A. Di Stefano, "Stratigraphic features of the Maltese Archipelago: a synthesis”, Natural Hazards, vol. 86, no. 2, pp. 203-231, 2017.

[2] S. Devoto, E. Forte, M. Mantovani, A. Mocnik, A. Pasuto, D. Piacentini, and M. Soldati, "Integrated monitoring of lateral spreading phenomena along the north-west coast of the Island of Malta”, in Landslide Science and Practice, Vol. 2, C. Margottini, P. Canuti, and K. Sassa, Eds. Springer-Verlag, Berlin Heidelberg, 2013, pp. 235-241.

[3] M. Mantovani, S. Devoto, E. Forte, A. Mocnik, A. Pasuto, D. Piacentini, and M. Soldati, "A multidisciplinary approach for rock spreading and block sliding investigation in the north-western coast of Malta”, Landslides, vol. 10, no. 5, pp. 611-622, 2013.

[4] S. Devoto, S. Biolchi, V. M. Bruschi, S. Furlani, M. Mantovani, D. Piacentini, A. Pasuto, and M. Soldati, M., "Geomorphological map of the NW Coast of the Island of Malta (Mediterranean Sea)", Journal of Maps, vol. 8, no. 1, pp. 33-40, 2012.

[5] F. Foglini, M. Prampolini, A. Micallef, L. Angeletti, V. Vandelli, A. Deidun, M. Soldati, and M. Taviani, "Late Quaternary coastal landscape morphology and evolution of the Maltese Islands (Mediterranean Sea) reconstructed from high resolution seafloor data”, in Geology and Archaeology: Submerged landscapes of the continental shelf, J. Harff, G. Bailey, and F. Lüth, Eds. Geological Society, London, Special Publications, 2016, 411, pp. 77-95.

[6] M. Prampolini, F. Foglini, S. Biolchi, S. Devoto, S. Angelini, and M. Soldati, "Integrated geomorphological map of emerged and submerged areas of northern Malta and Comino (central Mediterranean Sea)”, Journal of Maps, 2017, in press. 
[7] S. Devoto, M. Mantovani, A. Pasuto, D. Piacentini, and M. Soldati "Long-term monitorning to support landslide inventory maps: the case of north-western coast of the Island of Malta”, in Engineering Geology for Society and Territory, Vol. 2, G. Lollino, D. Giordan, G.B. Crosta, J. Corominas, R. Azzam, J. Wasowski, and N. Sciarra, Eds. Springer International Publishing, Switzerland, 2015, pp. 1307-1310

[8] M. Soldati, T.T. Barrows, and M. Prampolini, "Landslides and sea level changes: evidence of the complex geomorphologica evolution of the NW coast of Malta from exposure dating using cosmogenic nuclides”, Rendiconti Online della Società Geologica Italiana, vol. 40, no. 1, p. 368, 2016.

[9] K. Lambeck, F. Antonioli, M. Anzidei, L. Ferranti, G. Leoni, and S. Silenzi, "Sea level change along the Italian coasts during Holocene and prediction for the future”, Quaternary International, vol. 232, pp. 250-257, 2011
[10] A. Micallef, F. Foglini, T. Le Bas, L. Angeletti, V. Maselli, A. Pasuto, and M. Taviani, "The submerged paleolandscape of the Maltese Islands: Morphology evolution and relation to Quaternary environmental change”, Marine Geology, vol. 335, pp. 129-147, 2013.

[11] D. Piacentini, S. Devoto, M. Mantovani, A. Pasuto, M. Prampolini, and M. Soldati "Landslide susceptibility modeling assisted by Persistent Scatterers Interferometry (PSI): an example from the northwestern coast of Malta”, Natural Hazards, vol. 78, no. 1, pp. 681-697, 2015

[12] M. Soldati, O. Maquaire, J.L. Zezere, D. Piacentini, and C. Lissak, "Coastline at Risk: Methods for Multi-Hazard Assessment", Journal of Coastal Research, Special Issue No. 61, pp. 335-339, 2011. 


\title{
The geomorphology of humanity
}

\author{
Paolo Tarolli \\ Department of Land, Environment, Agriculture and Forestry \\ University of Padova \\ Padova, Italy \\ paolo.tarolli@unipd.it
}

For millennia, natural processes such as tectonic uplift, volcanic, climate, erosion, sediment transport and deposition have shaped the Earth surface. The Earth science community also started to consider biota as a geomorphological agent that has a role in shaping the Earth surface, even if at a different scale and magnitude than that of other major forcings [1]. In the recent history, a different global force of geomorphic change has risen: humanity [2, $3,4,5,6]$. Human activities ranging from agriculture to mining, road networks, and urbanization are leaving their fingerprints on the landscapes as evident topographic signatures [4, 7] (Fig.1). These signatures have the capability to affect Earth surface processes. In this work, different landscapes, significantly characterized by such anthropogenic signatures, are analyzed.

At the end of this century, anthropogenic geomorphology will cover a large part of the Earth. The consequences on Earth surface processes (e.g. soil erosion and landslide related to surface water flow interception by roads, soil erosion and mass movements related to mining activities, runoff and soil erosion associated with land use changes and issues related to anthropogenic drainage systems) will be significant [4]. Our Society should find solutions to minimize such environmental criticalities providing a global inventory of the human topographic signatures [5] through a constant monitoring of the landscapes, and rethinking the land use planning.

\section{REFERENCES}

[1] W.E. Dietrich and J.T. Perron, "The search for a topographic signature of life”, Nature, vol. 439, pp. 411-418, 2006.

[2] S.J. Price, J.R. Ford, A.H. Cooper,and C. Neal, "Humans as major geological and geomorphological agents in the Anthropocene: the significance of artificial ground in Great Britain”. Phil. Trans. R. Soc. A, vol. 369, pp. 1056-1084, 2011.

[3] R.L. Hooke and J.F. Martin-Duque, "Land transformation by humans: A review”, GSA Today, vol. 22, pp. 4-10, 2012.

[4] P. Tarolli and G. Sofia, "Human topographic signatures and derived geomorphic processes across landscapes”, Geomorphology, vol. 255, pp. 140-161, 2016.

[5] P. Tarolli, G. Sofia, and E.C. Ellis, "Mapping the topographic fingerprints of humanity across Earth”, Eos, vol. 98, 2017. doi:10.1029/2017EO069637

[6] A.G. Brown, S. Tooth, J.E. Bullard, D.S.G. Thomas, R.C. Chiverrell, A.J. Plater, J. Murton, V.R. Thorndycraft, P. Tarolli, J. Rose, J. Wainwright, P. Downs, and R. Aalto, "The Geomorphology of the Anthropocene: emergence, status and implications”, Earth Surface Processes and Landforms, vol. 42, pp. 71-90, 2017.

[7] P. Tarolli, G. Sofia, and C. Wenfang, "The Geomorphology of the Human Age", Encyclopedia of the Anthropocene, 2017. doi:10.1016/B978-0-12-409548-9.10501-9

[8] P. Tarolli, F. Preti, and N. Romano, "Terraced landscapes: from an old best practice to a potential hazard for soil degradation due to land abandonment”, Anthropocene, vol. 6, pp. 10-25, 2014.

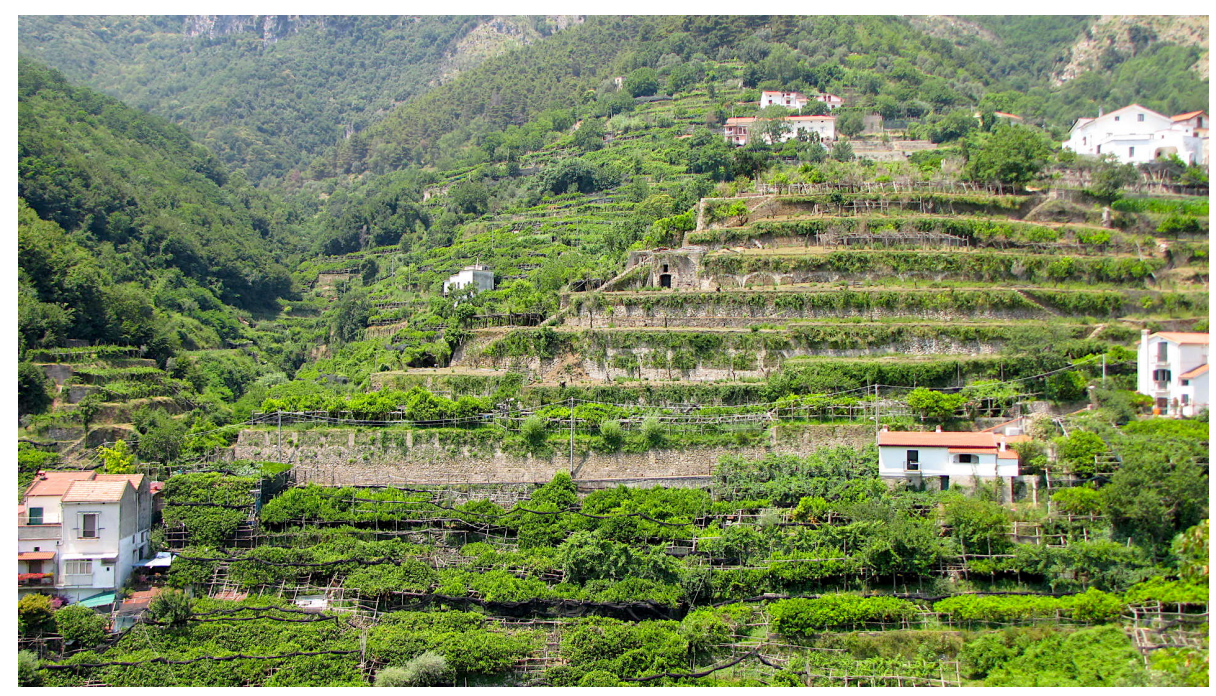

Fig. 1. Terraces near Amalfi Coast (Salerno, Italy) (photo by P. Tarolli). Agricultural terraces are among the most evident and extensive anthropogenic signatures on Earth [8]. 


\title{
Danube Delta Coastline Dynamics in the last 160 years
}

\author{
Florin Tătui, Alfred Vespremeanu-Stroe, Florin Zăinescu, Ștefan Cnstantinescu \\ Faculty of Geography \\ University of Bucharest \\ Bucharest, Romania \\ florin.tatui@geo.unibuc.ro
}

\begin{abstract}
Danube Delta coastline experienced variable dynamics in the last $\mathbf{1 6 0}$ years, depending on the factors and processes which had the leading role at different temporal and spatial scales. At centennial time-scales, shoreline evolution was highly influenced by the threefold decrease of Danube sediment discharge in the last century, while on multi-decadal scale, storminess (as a result of climate variability) was the driving factor for coastline changes. Overall, human influence superposed on the natural response of the coast to variability of climatic, hydrological and hydrodynamic (marine) factors. All these changes resulted in different shoreline morphology and configuration along Danube Delta coast.
\end{abstract}

Keywords - erosion/progradation; LST; river sediment discharge; storminess; climate variability

\section{INTRODUCTION}

Shorelines exhibit considerable variations of their position over a wide range of spatial and temporal scales. On sandy coasts, shoreline accretion and erosion are generally associated to low- and high-energy wave conditions.

Wave-dominated deltaic coasts depend on the balance between wave climate and sediment supply ([1], [2]), which controls the medium and long-term shoreline evolution. Interestingly, the common plan shapes of the wave-dominated lobes impose different wave exposures and longshore sediment transport magnitudes on the lobe flanks, characterized by ever changing aspects which make these sandy coasts some of the most mobile world coastlines.

The objective of this study is to examine and explain the factors which have driven the Danube Delta coastline dynamics at multi-annual to multi-decadal and centennial time-scales in the last 160 years.

\section{GENERAL DATA}

\section{A. Study Area}

The Danube Delta coast (both Romanian and Ukrainian sectors) consists of approximately $220 \mathrm{~km}$ of tideless, medium-energy low-lying sandy beaches interrupted by multiple river mouths and, sometimes, by engineering structures (Fig. 1). The Romanian Danube Delta coast consist of five littoral cells, most of them being dominated by erosion. Waves from the north-eastern directions are dominant in terms of both magnitude and frequency, inducing a strong net southward oriented longshore sediment transport (LST) on most coastal sectors along Danube Delta coast.

\section{B. Data \& Methods}

Our analysis is based on multiple shorelines extracted from historical and modern maps (since mid-19th century), recent medium to high resolution satellite images (since 1984), aerial photos (since 1969), GPS surveys (available after 1990) and LIDAR data (2011), which were comparatively analyzed by means of GIS techniques (Digital Shoreline Analysis System-DSAS; [3]).

\section{RESUlTS AND DISCUSSIONS}

Nowadays, more than half ( $55 \%$ ) of the Romanian Danube Delta shoreline is affected by erosion. The present coastline configuration is the result of the long-term evolution of this deltaic coast. In the last 160 years, shoreline evolution on different sectors of the Danube Delta was dominated by either accumulation or erosion. The accumulation sectors showed mean shoreline progradation rates varying from 10-25 m/year, for Sulina beach and Sf. Gheorghe secondary delta, to 40-70 m/year, along Chilia secondary delta. They are linked to various driving factors and processes as follows:

- active deltaic lobes (Chilia and Sf. Gheorghe secondary delta), in direct connection with high Danube sediment discharge;

- updrift beaches of natural river mouths (Sf. Gheorghe), dominated by accumulation induced by morphologic (mouth bar) and hydrodynamic (river plume) groin effect on the longshore sediment transport (LST);

- engineering structures (jetties and harbor dykes), inducing accumulation either updrift (Midia Harbor) or 
immediately downdrift (Sulina jetties, as a result of wave diffraction and formation of eddy-like counter-currents).

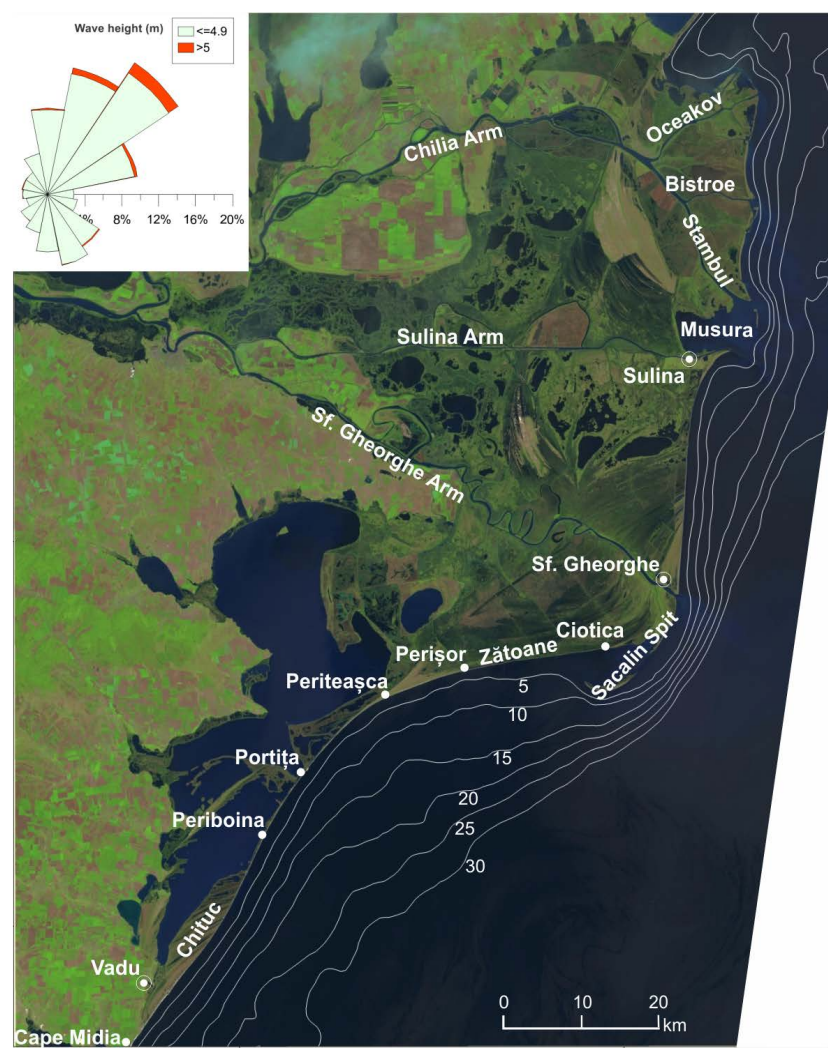

Fig. 1. Danube Delta coast (LANDSAT image from May 2013).

Contrary, the erosive areas registered mean shoreline retreating rates of maximum $20 \mathrm{~m}$ /year and are associated to:

- the boundary between two littoral cells (overlaid on the divergence zones of nearshore currents) and the updrift sectors of stable littoral cells (i.e. central part of Sulina-Sf. Gheorghe coast, Zătoane and Portiţa Periboina sectors);

- the long-term retreating deltaic lobes following their abandonment, which let protuberant coasts exposed to wave reworking (Sulina), whose erosion was intensified by the lack of longshore supplied sediments due to river jetties construction.

Depending on the temporal and spatial scales taken into consideration, different driving forces changed the leading role in the dynamics of Danube Delta shoreline in the last 160 years.

At centennial time-scale, the threefold decrease of Danube sediment discharge in the last century (especially after 1950, as a result of dams'construction in the Danube watershed - [4]) explains the significantly higher shoreline migration rates and area changes between 1856 and 1961/1979 in comparison with the subsequent period, especially along the accumulative sectors (Fig. 2). For the Chilia prograding lobe, this resulted in the decrease with more than $75 \%$ of the progradation rates and with approximately $90 \%$ of the corresponding area change rates, marking its transition, since mid-20th century, from fluvial-dominated morphology to wave-influenced aspect and behavior ([5]). This resulted in a change of coastline configuration from a crenulated shoreline (in $19^{\text {th }}$ century and the beginning of $20^{\text {th }}$ century) to progressive shoreline straightening (1935 - 1980) and the development of spits and barrier islands (after 1980) - [6] .

Also, since the beginning of the 20th century, the asymmetric Sf. Gheorghe lobe experienced dramatic changes of its millennial prograding pattern expressed by the complete cessation of the updrift coastal progradation and the prevalence of erosion in front of the river mouth, whose sediments are feeding far-positioned downdrift depocentres. These changes are reflected by the recent (1930-present) river mouth dynamics, characterized by cessation of its long-term seaward expansion in favor of downdrift migration, indicating the transition of the Sf. Gheorghe mouth from an asymmetric to a deflected waveinfluenced delta morphology.

The erosive sectors presented a much lower variability in terms of both shoreline retreat and erosional surface rates between the two analyzed time intervals (Fig. 2).

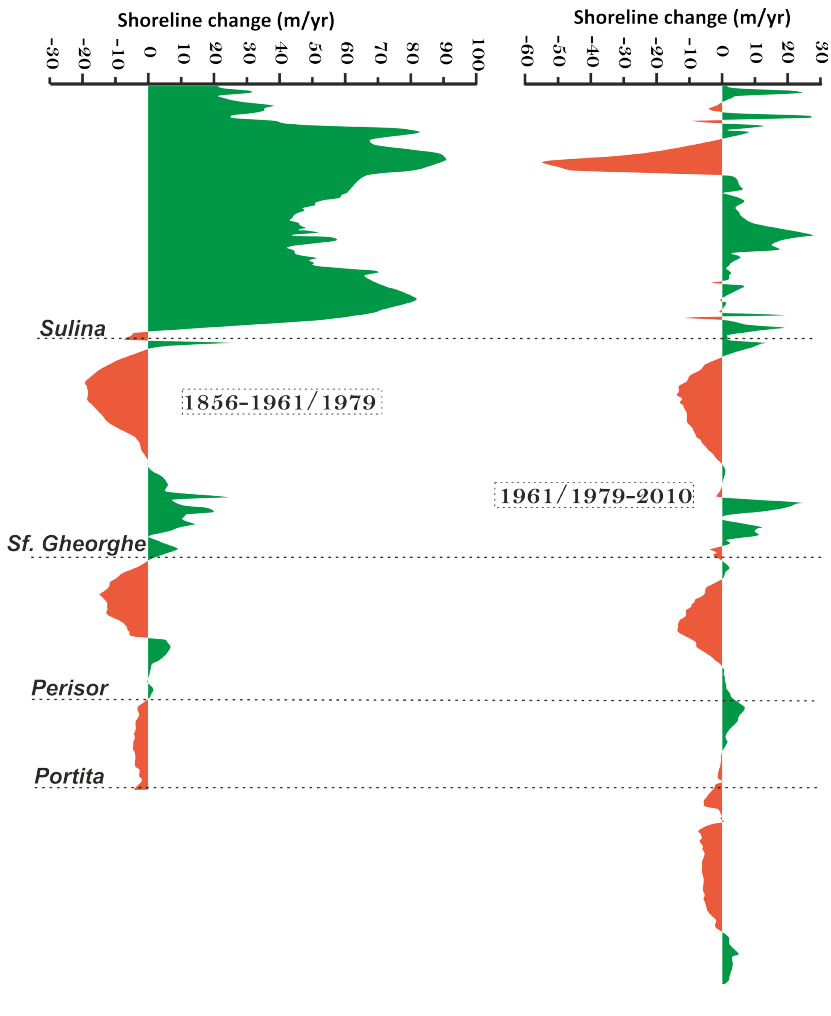

Fig. 2. Different shoreline changes/behaviour between 1856-1961/1979 and 1961/1979-2010 time intervals.

At multi-decadal scale, different modes of climate variability (e.g. North Atlantic Oscillation) control the storminess variations along the Danube Delta coast. Hence, active storminess during 1961-1979 time interval determined very high shoreline dynamics, with two-three times higher shoreline migration rates than afterwards, when a decrease in storminess favored less dynamic coastlines (on both prograding and erosive sectors) - [7]

At inter-annual scale, waterline mobility is influenced by storm regime and river floods.

Nowadays, coastal engineering structures play a very important role in shoreline behavior. For example, Sulina jetties (which are currently developing approximately $9 \mathrm{~km}$ offshore) interrupt the dominant southward directed longshore drift, altering nearshore circulation and inducing high accumulation rates updrift (Musura Bay) or immediately downdrift (Sulina beach), whilst an increasing coastal erosion occurs for large areas downdrift. 


\section{CONCLUSIONS}

In the past 160 years of evolution, Danube Delta coastline experienced significant morphodynamic variability related to different driving forces which changed the leading role between them depending on the considered temporal and spatial scales.

At centennial time-scale, the threefold decrease of Danube sediment discharge in the last century (especially after 1950, as a result of dams'construction in the Danube watershed) explains the significantly higher shoreline migration rates and area changes between 1856 and $1961 / 1979$ in comparison with the subsequent period, especially along the accumulative sectors of secondary deltas.

At multi-decadal scale, different modes of climate variability (e.g. North Atlantic Oscillation) control the storminess variations and, ultimately, the coastal processes intensity along the Danube Delta coast.

Our findings should support the sustainable coastal management and planning, providing a better understanding of past and present coastal processes along the Danube Delta coast.

\section{ACKNOWLEDGMENT}

This study was financed by the Romanian National Authority for Scientific Research (CNCS-UEFISCDI) and European Union (EU) under ERA.NET RUS-Plus grant no. 42/2016 (BS STEMA) awarded to AVS.

\section{REFERENCES}

[1] J.M. Coleman and L.D. Wright, "Modern river deltas; variability of processes and sand bodies”, in Deltas, models for exploration, M.L. Broussard, Ed. Houston Geological Society, 1975, pp. 99-149.

[2] J.P. Bhattacharya and L. Giosan, "Wave-influenced deltas: geomorphological implications for facies reconstructions", Sedimentology, vol. 50, pp. 187-210, 2003.

[3] E.R. Thieler, E.A. Himmelstoss, J.L. Zichichi and A. Ergul, "Digital shoreline analysis system (DSAS) version 4.0-an ArcGIS extension for calculating shoreline change”. U.S. Geological Survey Open-File Report 2008-1278, 2009.

[4] L. Preoteasa, A. Vespremeanu-Stroe, A., F. Tătui, F. Zăinescu, A. Gabor-Timar and I. Cîrdan, "The evolution of an asymmetric deltaic lobe (Sf. Gheorghe, Danube) in association with cyclic development of the river-mouth bar: Long-term pattern and present adaptations to human-induced sediment depletion", Geomorphology, vol. 253, pp. 59-73, 2016.

[5] A. Vespremeanu-Stroe, A., F. Tătui, S. Constantinescu and F. Zăinescu, "Danube Delta Coastline Evolution (1856-2010)”, in Landform Dynamics and Evolution in Romania, M. Rădoane and A. Vespremeanu-Stroe, Eds. Springer International Publishing, 2017, pp. 551-564.

[6] A. Vespremeanu-Stroe and L. Preoteasa, "Morphology and the cyclic evolution of Danube Delta spits”, in Sand and gravel spits, G. Randazzo, A. Cooper and D. Jackson J., Eds. Springer International Publishing, 2015, pp. 327-339.

[7] A. Vespremeanu-Stroe, S. Constantinescu, F. Tătui and L. Giosan, "Multi-decadal evolution and North Atlantic Oscillation influences on the dynamics of the Danube delta shoreline”, Journal of Coastal Research, vol. 50, pp. 157-162, 2007. 


\title{
Creating an analysis model in order to identify solutions for sustainable development of ski areas in Romania
}

\author{
Mădălina Teodor, Robert Dobre, Laurențiu Ilie, Gabriel Stănoiu \\ Geomorphology - Pedology - Geomatics Department \\ Faculty of Geography, University of Bucharest \\ Bucharest, Romania
}

\begin{abstract}
The aim of this study is to analyze and assess the ski areas in Romania. To achieve this project were analyzed 92 resorts from Romanian. In this analysis were taken into account both geographical (position, accessibility, the ski slopes disposition in correlation with the slopes aspect, the slopes that influence the diversity of the ski areas, the ski areas visibility on the internet) and socio-economic factors (the services provided by the ski areas administrators, related tourism services, the state of the ski slopes, the types of the existing tourist facilities).
\end{abstract}

Keywords_-ski; develompent; suitable areas; efficienty

\section{INTRODUCTION}

For the study were made field analyze for all ski resort. Field analysis was combined with laboratory analysis by using GIS techniques. In order to identify the most complex ski areas in Romania were calculated several relevant indices. They were weighted and placed in a formula in order to achieve a ranking of functionality ski areas in Romania [1], [2].

\section{STUDY AREA}

The analysis was performed for all ski areas identified in Romanian Carpathians. We identified $256.6 \mathrm{~km}$ of ski slopes relate to the 266 ski slopes (111 easy slopes, 114 medium slopes, 40 difficult slopes). Cableway facility is composed by 5 lifts, 8 gondolas, 30 chair lifts, 140 ski lifts, 8 baby-ski and 5 conveyors.

The distribution ski areas map in the counties based on the number ski area, indicates the presence of 44 ski areas in Harghita county, 33 ski areas in Prahova County, 29 in Hunedoara county, 26 ski areas in the county of Maramures. Conversely, the fewest ski areas are recorded in Iasi, Bacau, Arges, Bacau, Gorj, Iaşi (1 ski area), Bihor and Bistrita Nasaud (by 3 ski areas), Neamt Mures (4 ski areas).

\section{Methodology}

In order to identify the most complex ski areas in Romania were calculated several relevant indices [2]. They were weighted and placed in a formula in order to achieve a ranking of functionality ski areas in Romania.

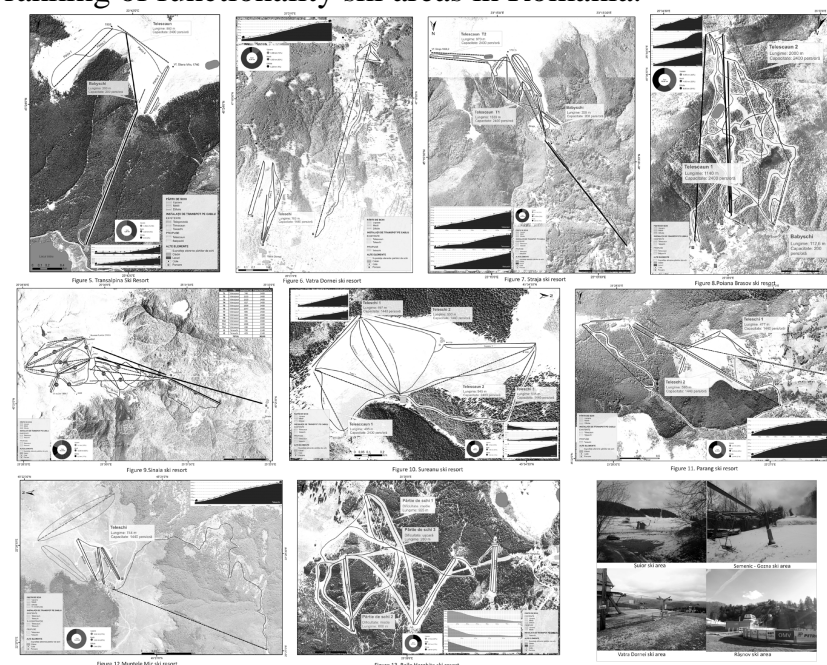

Fig. 1. Ski areas develpement proposed maps

Length index - is calculated by adding the lengths of all ski slopes in each area according to the formula: $\mathrm{Il}=$ Elp.

The rate of return is the ratio of the sum of all the slopes of a ski area and the amount of lift installations lengths. To calculate the rate of return was applied the formula (where $\mathrm{Rr}=$ return ski area, $\sum \mathrm{lp}=$ Sum of slopes lengths in the ski area, $\sum$ lp $=$ Sum of cable transport lengths area):

$$
R r=\frac{\sum l p}{\sum l t} \geq 1
$$

Transport index of ski areas indicates the maximum transport capacity of all lift facilities of a ski area. This index is calculated by summing the transport coefficients depending on the type of transport facilities in each ski area by applying the formula [2]: $\mathrm{Ct}=\sum \mathrm{It}$ where $\mathrm{Ct}=$ transport capacity and It = transport index.

The formula used to calculate the functionality of ski areas took into account three indicators (sum of lengths the ski slopes in every ski area with a share of $20 \%$, the 
rate of return was granted a share of $40 \%$ and the transport capacity using all facilities cableway of the resort - 40\%):

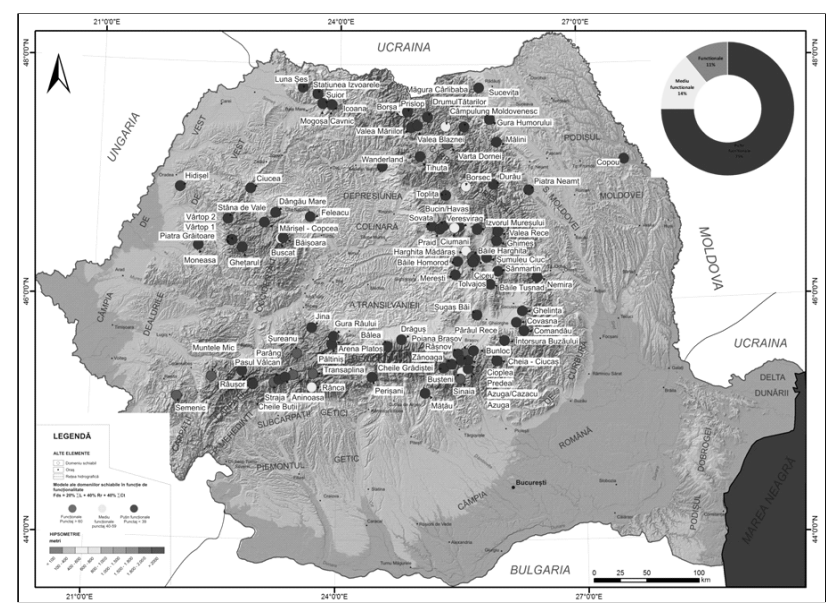

Fig. 2. Romanian ski areas location based on the functionality ski areas final score

TABLE II. SKI AREAS CLASSIFICATION DEPENDING ON FUNCTIONALITY

\begin{tabular}{|c|c|c|c|c|c|c|c|c|}
\hline Ski area & $\begin{array}{c}\text { Lengt } \\
h \\
(\mathrm{~m}) \\
\end{array}$ & $\begin{array}{c}\text { Lengt } \\
\text { h } \\
\text { score }\end{array}$ & $\begin{array}{c}\text { Cable } \\
\text { way } \\
(\mathrm{m}) \\
\end{array}$ & $\begin{array}{c}\text { Rate } \\
\text { of } \\
\text { retur } \\
n\end{array}$ & $\begin{array}{c}\text { Rate } \\
\text { of } \\
\text { retur } \\
n \\
\text { score } \\
\end{array}$ & $\begin{array}{c}\text { Capa } \\
\text { city } \\
\text { factor } \\
\text { (pers/ } \\
\text { h) }\end{array}$ & $\begin{array}{c}\text { Capa } \\
\text { city } \\
\text { factor } \\
\text { score }\end{array}$ & $\begin{array}{c}\text { Fi } \\
\text { nal } \\
\text { sco } \\
\text { re } \\
\end{array}$ \\
\hline Semenic & 10415 & 20 & 2950 & 3,53 & 40 & 36 & 40 & $\begin{array}{c}10 \\
0 \\
\end{array}$ \\
\hline Sinaia & 19878 & 20 & 9895 & 2,01 & 20 & 100 & 40 & 80 \\
\hline Straja & 20014 & 20 & 7651 & 2,62 & 20 & 80 & 40 & 80 \\
\hline Șureanu & 9410 & 20 & 1830 & 5,14 & 40 & 24 & 20 & 80 \\
\hline $\begin{array}{l}\text { Poiana } \\
\text { Brașov } \\
\end{array}$ & 22060 & 20 & 11412 & 1,93 & 10 & 98 & 40 & 70 \\
\hline Parâng & 9420 & 20 & 7170 & 1,31 & 10 & 54 & 40 & 70 \\
\hline $\begin{array}{c}\text { Băile } \\
\text { Harghita }\end{array}$ & 4759 & 10 & 1920 & 2,48 & 20 & 30 & 40 & 70 \\
\hline $\begin{array}{c}\text { Transalp } \\
\text { ina Ski } \\
\text { Resort }\end{array}$ & 6092 & 10 & 5346 & 1,14 & 10 & 72 & 40 & 60 \\
\hline $\begin{array}{c}\text { Vatra } \\
\text { Dornei }\end{array}$ & 6799 & 10 & 5756 & 1,18 & 10 & 38 & 40 & 60 \\
\hline $\begin{array}{c}\text { Muntele } \\
\text { Mic }\end{array}$ & 4652 & 10 & 3130 & 1,49 & 10 & 30 & 40 & 60 \\
\hline
\end{tabular}

For calculating the employment rate to establish a model of sustainable development it is necessary to calculate the optimum number of skiers on a ski slope. To determine the optimum number of skiers who may find themselves simultaneously on a ski slope was considered a square of $12 \mathrm{~m}$. The area ski areas were divided by the area of a square (144 square kilometres) to obtain the number of squares covering ski area.

We applied the next formula in order to determine the optimum number of skiers who can be simultaneously on the slope, knowing the number of squares covering the surface of the ski area:

$$
\mathbf{O}=2 \mathbf{P}+2
$$

Where: $\mathrm{O}=$ the optimum number of skiers at a time on the slope, $\mathrm{P}=$ the number of squares covering the surface of the ski area.
The optimal rate of occupancy of a ski slope indicates that is the ratio between the optimum number of skiers that ski simultaneously on a ski slope without bothering each other and the maximum number of skiers on the facility cableway may transport. To determine the optimal rate of occupancy the next formula was applied:

$$
R o=\frac{2 P+2}{\sum I t * 100}=\frac{2 P+2}{C t * 100}=\frac{o}{C c}
$$

Comfort factor (CcF) was calculated by applying the formula:

$$
\mathrm{Ccf}=\sum \mathrm{It} * 100-(2 \mathrm{P}+2)=\mathrm{Ct} * 100-(2 \mathrm{P}+2)=\mathrm{Cc}-\mathrm{O} \text { (4). }
$$

\section{RESULTS AND CONCLUSIONS}

To optimize the functionality of ski areas were identified some solutions to increase profit ski areas. It is noted that most major ski areas in the country have a low capacity cable transport facilities. This is transposed in the comfort of skiers who often queue to be able to reach the top of the ski slopes while round skiing surface is utilized to the maximum.

Depending on the occupancy rate (Ro) and the comfort factor (CCF) calculated for the ten ski areas were proposed following development maps:

The advantages of this analysis are numerous. It is noticed: the incretion of the resort visibility in the country, increasing the attractiveness and the competitiveness of the ski areas. Also, it is noticed the need to satisfy the requirements of a wider range of skiers, practicing smart tourism, attracting tourists from further afield, foreign tourists or the possibility of using the new infrastructure for practicing various mountain activities (mountain biking, hiking, recreation) for at the resorts situated at the end of the ranking [4].

From the analysis achieved in the field, we observed that the improvement of the provided services and the proper management of the ski area determines tourist's loyalty and thus increase their number.

Looking at the major European mountain resorts there is a better use of the ski area, sound management and integrated management of tourist facilities and infrastructure used by skiers. It wants to implement a comparable system in the Romanian Carpathian area.

In conclusion, by calculating all these indices for the ski areas (index transmission rate of return, occupancy, rate of transport), there was a need to develop cableway facilities in $90 \%$ of case studies analysed (Semenic, Sinaia, Straja, Șureanu, Poiana Brașov, Parâng, Transalpina Ski Resort, Vatra Dornei, Muntele Mic). Thus, using analysis (done on the field and working with GIS techniques) was observed the cableway inefficiency (identification of overcrowding at the starting stations starting stations and low density of skiers on the ski slopes), which have a capacity maximum carrying less than the number of skiers, especially on weekends or during holidays.

\section{REFERENCES}

[1] M. Teodor and R. Dobre, "Relief suitability for developing a macro ski area between Predeal and Azuga Resorts", Revista de Geomorfologie, vol. 17, pp. 95-106, 2015. 
[2] M. Teodor, "Proiectarea, dezvoltarea și managementul domeniilor schiabile din România”, teză de doctorat, 2016. (in Romanian)

[3] M. Teodor, I. Laurențiu, and R. Dobre, "Using GIS techniques to create the catalog of Romanian ski resorts", Analele Universități din București, seria Geografie, Nr. LXV, pp. 81-92, 2016.
[4] M. Voiculescu, F. Popescu, T. M. Oance, M. Olaru, and A. Onaca, "Features of ski area from the Romanian Banat", Forum geografic. Studii și cercetări de geografie și protecția mediului, vol. 10, no. 1, pp. 58-69. doi: 10.5775/fg.2067-4635.2011.019.i 


\title{
Cave morphology provides evidence of polyphase tectonics - an example from the Isverna karst system, South Carpathians
}

\author{
Laura Tîrlă \\ Faculty of Geography \\ University of Bucharest \\ Bucharest, Romania \\ tirla@geo.unibuc.ro
}

\author{
Virgil Drăguşin, Marius Vlaicu, Ionuț Mirea \\ Emil Racoviță Institute of Speleology \\ Romanian Academy \\ Bucharest, Romania
}

\author{
Daniela Dimofte, Relu-Dumitru Roban \\ Faculty of Geology and Geophysics \\ University of Bucharest \\ Bucharest, Romania
}

\begin{abstract}
Passage morphology and well-preserved kinematic indicators in a limestone-mélange contact cave from the South Carpathians provide evidence of thrusting mechanisms that occurred during the Late Cretaceous nappe emplacement. Large-scale normal faults occurred during the Eocene to Oligocene orogen-parallel extension, were deformed during the Late Miocene dextral strike-slip movements, which shaped a typical Riedel geometry across the Isverna area. Comparative orientation analysis of structural and geomorphological features indicates that karstification processes were directed along the NE-SWoriented normal faults, subsequently dissected by NW-SEoriented R'-shears. Where conditions were favorable, minor synthetic P-fractures inherited the normal fault planes. This study outlines the role of karst and caves in general and contact caves in particular in providing information on the mechanisms that controlled the polyphase tectonic evolution of an orogen area.
\end{abstract}

Keywords- karst; contact cave; thrust fault; structural analysis; Riedel fractures; tectonic geomorphology; South Carpathians

\section{INTRODUCTION}

Well-developed cave systems in the European orogenic wedges are related to the limestone-siliciclastite contact karst. This lithologic context is frequently linked to thinskinned thrust tectonics, commonly found in the accretionary wedges of the European alpine orogens [1]. The aquifers consist in porous limestone juxtaposed on clayey or clay-matrix formations of very low permeability.

Cave geometry in a karst system can be correlated with local and regional fault mechanisms. Caves may provide useful and novel evidences on the small- to large-scale tectonics, otherwise inaccessible from the surface, e.g. [2] and references therein. Conversely, tectonic facets such as fault sides or décollements (i.e., a type of thrust fault) which provided the path for cave-forming processes are able to provide new insights on speleogenesis. A particular geological setting for cave development can be found in the SW South Carpathians, where the Danubian and Severin nappes complexes are exposed. Ascunsă Cave [3] developed on the Cerna Nappe décollement and preserves structural, mineralogical, and geomorphic records of the deformation mechanisms.

We present here new evidences on thin-skinned thrust tectonics inferred from speleomorphology of the Ascunsă Cave, part of the active Isverna karst system (Mehedinți Mountains). Cave morphology and microtectonic records provided original information on the kinematic mechanism of the Cerna Nappe during its emplacement. Comparative analysis of joints, fractures, faults and cave passages revealed structural and geomorphic relationships that recorded the polyphase tectonic activity of the SW Carpathians. We demonstrate the way in which the development of karst conduits and interconnected surface landforms was directed along the normal faults and the Riedel shears that intersect across the Isverna hydrostructure.

\section{Lithologic AND STRUCTURAL SETTING}

The Isverna karst system is located in Mehedinti Mountains (SW South Carpathians), at elevations between $400 \mathrm{~m}$ and $1200 \mathrm{~m}$. It has developed into the uppermost cover nappe outcropping in the Danubian window - the Cerna Nappe. Its litho-stratigraphic units are: (a) 150-200 m-thick Urgonian limestones at the base, of BarremianAptian age; (2) Cenomanian-Middle Turonian thin-bedded marls and sandstones (Nadanova Beds); and (3) Upper Turonian-Maastrichtian tectonic mélange (s.l.) at the top. It overthrusts the Coșuștea Nappe, comprising siliciclastic sequences and mélange [4]. The latter consist in chaotically disposed 'blocks-in-matrix'-type fabric (or bim 
rocks), involving tectonic, sedimentary and gravitational forming processes [5]. The Urgonian limestones are karstified, all the conduits joining to a single common resurgence: Isverna Cave, at $450 \mathrm{~m}$ a.s.l. [6]. Ascunsă Cave is located at $1080 \mathrm{~m}$ a.s.l., where a small creek has deepened into the overthrust limestone and reached the underlying mélange. The cave entrance is located at the limestone-mélange contact. The rich aquifer facilitates water infiltration and organized flow along an extensive system of joints, fractures, bedding planes and solution cavities [7].

The Isverna hydro-structure is entirely comprised between the Obârșia Cloșani-Brebina (N) and IsvernaPonoarele (S) dextral strike-slip faults, hereafter referred to as the OCB and IP faults, respectively. They meet the NESW-oriented Cerna-Jiu fault system to the west.

\section{METHODOLOGY}

Structural analysis relied on examining the sense of shear and a comparative orientation study. Two types of Riedel shears were used: the microshears visible on the cave walls related to limestone sheet overthrust movement, and the fracture sets developed across the Isverna hydrostructure.

Cave survey and geomorphological mapping of the surface karst were used to obtain the structural data - faults and fractures $(\mathrm{n}=186)$ from an area of about $38 \mathrm{~km}^{2}$. We analyzed the type of faults and Riedel fractures according to their orientations and position with respect to principal displacements: the orogen-parallel normal faults, the major synthetic R and antithetic R' shears, and the minor synthetic P-fractures. For the strike-slip system, the direction of the maximum compressive stress $\left(\sigma_{1}\right)$ was inferred from fracture geometry, according to Anderson's theory of faulting.

Comparative orientation analysis between the fault and fracture system and the segments of Ascunsă and Isverna caves (38 and 123 segments, respectively) was combined with microtectonic measurements on randomly distributed joint sets across the entire Isverna hydro-structure $(n=759$ joints). Orientations were plotted on rose diagrams as nonpolar frequency lines organized into 10-degree bins. We performed the survey of Ascunsă Cave using a Leica Disto X310 laser range finder fitted with electronic compass and clinometer. We focused on the passage morphometry and its relationship to the thrust fault and the strike-slip shear system. Cave and surface karst survey was followed by data integration into a GIS environment.

\section{RESULTS}

\section{A. Structural mineral fabrics as kinematic indicators}

The 1-5 mm-thin laminae of the argillaceous matrix are oriented parallel to the limestone ceiling and exposed throughout the sides of the main passage. Where present, microshears display a Riedel-type arrangement indicating the sense of shear towards WNW.

A giant slickenside forms the cave ceiling at $\sim 25 \mathrm{~m}$ from the entrance. Well-preserved mineral and mechanical lineations were found both on the ceiling and the opposite

This study was financially supported by the IFA-CEA C4-08 (FREem) project slickensides consisting in detached limestone slabs. Position of the calcite slickenfibers is $292 / 25$, showing the direction of movement of the limestone edge over the mélange, which is also towards WNW.

\section{B. Evidence from speleomorphology}

Cave passages consist in alternating large chambers (up to $20 \mathrm{~m}$ in width and $10 \mathrm{~m}$ in height in the Great Chamber) and very narrow phreatic tubes $(\sim 0.5 \mathrm{~m}$ in width), with interposed passages of small to intermediate size (2-3 $\mathrm{m}$ in width and height). The cave currently reaches the maximum depth of $-132.2 \mathrm{~m}$, with further exploration possibilities.

The chambers have a planar ceiling dipping under various angles $\left(25^{\circ}-55^{\circ}\right)$, an indicator for the typical ramps-and-flats morphology of thrust faults. The ceiling is well-decorated with stalactites and locally with shields. Many types of speleothems cover the uneven floor, having a chaotic arrangement. Phreatic tubes were carved mostly or entirely into the overlying limestone beds and walls preserve different-sized scallops, small cupolas formed by evorsion and ceiling channels. The longitudinal profile of the Ascunsă Cave shows the current dip of the deformed décollement. The general fault dip inferred from the cave dip ranges between $20^{\circ}-25^{\circ}$, with the steep breaks formed both into the ceiling and the floor indicating the dropped blocks of the overlying limestone bedrock.

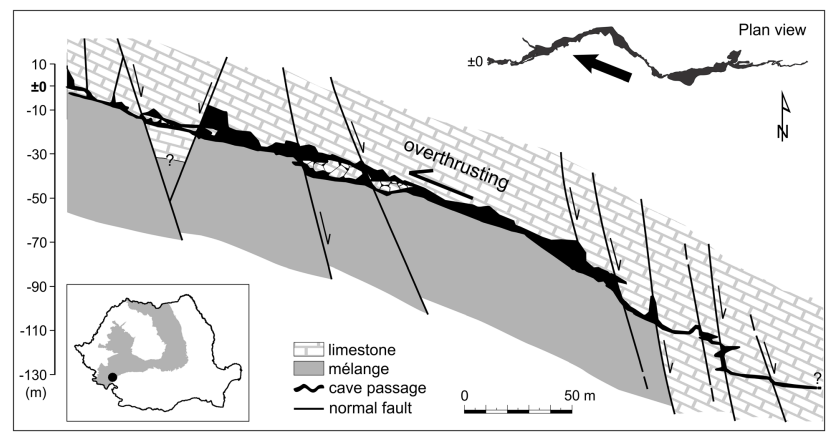

Fig. 1 Longitudinal profile of the Ascunsă Cave, adapted to typical ramps-and-flats structure of the thrust fault. The direction of movement of the limestone sheet during the Late Cretaceous nappe emplacement is shown by the black arrow in the plan view. The normal fault system is much younger and related to Early Tertiary orogen-parallel extension.

\section{Orientation analysis of joint sets, faults, fractures and cave passages}

Manually-extracted fractures from the strike-slip shear zone form the characteristic Riedel sets (Fig. 2). Preferred orientations are: E-W for the major strike-slip faults and minor parallel Y-fractures; ESE-WNW for the major synthetic R shears; NW-SE for the major antithetic R' shears; ENE-WSW for the minor synthetic P-fractures; and NNE-SSW for the deformed R' shears. However, we identified numerous short fractures striking on a NE-SW direction, which is not typical of a Riedel arrangement. Their probable origin will be discussed below.

Joint orientations differ considerably from the situation described above. Most joints $(n=235)$ are $\mathrm{W}$-E-oriented, corresponding to the major strike-slip movement. Another four preferred orientations are still noticeable: N-S, NE- 
SW, ENE-WSW and WNW-ESE. All of them have comparable samples in size (50-65 joints) and correspond to synthetic and antithetic fracture systems.

There is a high correlation between the fracture and cave passage orientations, which fall into two general directions: NW-SE and NE-SW (to ENE-WSW). Ascunsă Cave developed mostly along the ENE-WSW-oriented fractures (347 m, namely 75\% of its total length, which is $691.5 \mathrm{~m}$ [3]) and less along the NW-SE (103 m, meaning $15 \%$ of its length). In case of Isverna Cave, NE-SWoriented passages account for $1.91 \mathrm{~km}$ (50\%), W-Eoriented segments cumulate $1 \mathrm{~km}(25 \%)$, and those NWSE-oriented account for $0.68 \mathrm{~km}(17 \%)$. Its total measured length reaches $\sim 3.9 \mathrm{~km}[6]$.

Geomorphic relationships between the cave system and the exokarst were also driven by the structural network. Tens of sinkholes can be found on the less inclined surfaces of the limestone bedrock, spatially distributed along the $\mathrm{R}$ ' and $\mathrm{P}$ fractures. Their diameter ranges between 20-50 m, rarely exceeding $150 \mathrm{~m}$, and depths between 5-10 m.

\section{DISCUSSION}

The cave formed by removal of the argillaceous matrix through underground flow in an unconfined aquifer. Differential response of the limestone and bim rocks to water action under both phreatic and vadose conditions has resulted in extremely narrow or low passages alternating with large chambers. Formation of the great chambers was primarily controlled by the fault and fracture intersections. The narrow tubes correspond to minor tensile fractures developed into the dropped limestone hangingwalls. Scallops, cupolas and ceiling channels are typical evidence of an earlier phreatic flow phase. The cave continuously deepens along the ramps-and-flats contact between the mélange and the limestone cover.

The WNW-trending calcite slickenfibers preserved inside the cave $\left(292 / 25^{\circ}\right)$ certainly indicate the sense of displacement of the Cerna Nappe. This assumption is strengthened by the shear sense analysis of the Riedel microshears developed at the limestone-mélange contact.

Fault and fracture geometry indicates a structural arrangement typical to a dextral strike-slip shear zone [8], comprised between the OCB and the IP faults. Joint orientations reflect the general displacement trend of the strike-slip zone, corresponding to a W-E direction. Cave passages and surface karst landforms developed mainly along two preferred orientations: NE-SW, and NW-SE. These would normally correspond to R' shears and Pfractures, only that the latter are usually minor fractures unable to direct karstification at such scale without an extra-backing. The structural support seems to have been provided by an earlier fault system that pre-dates the strike-slip movements. Field and orientation analysis of several presumable P-fractures indicated that these took over the remnants of some older normal faults, intersected and displaced by the younger R' shears. Reconstruction of these large-scale faults (Fig. 2) shows their parallelism with the Cerna-Jiu master fault, striking NE-SW and located northwestward from the study area.

At Isverna Cave, located near the IP Fault, the synthetic $\mathrm{R}$ and conjugate $\mathrm{R}$ ' shears controlled the development of southern passages. Towards north, passages developed within the innermost displacement zone were directed mainly along the deformed normal faults and P-fractures.

We inferred the type of faults and fractures mainly from karst geomorphology in relation to the polyphase tectonic evolution of the South Carpathians, as follows:

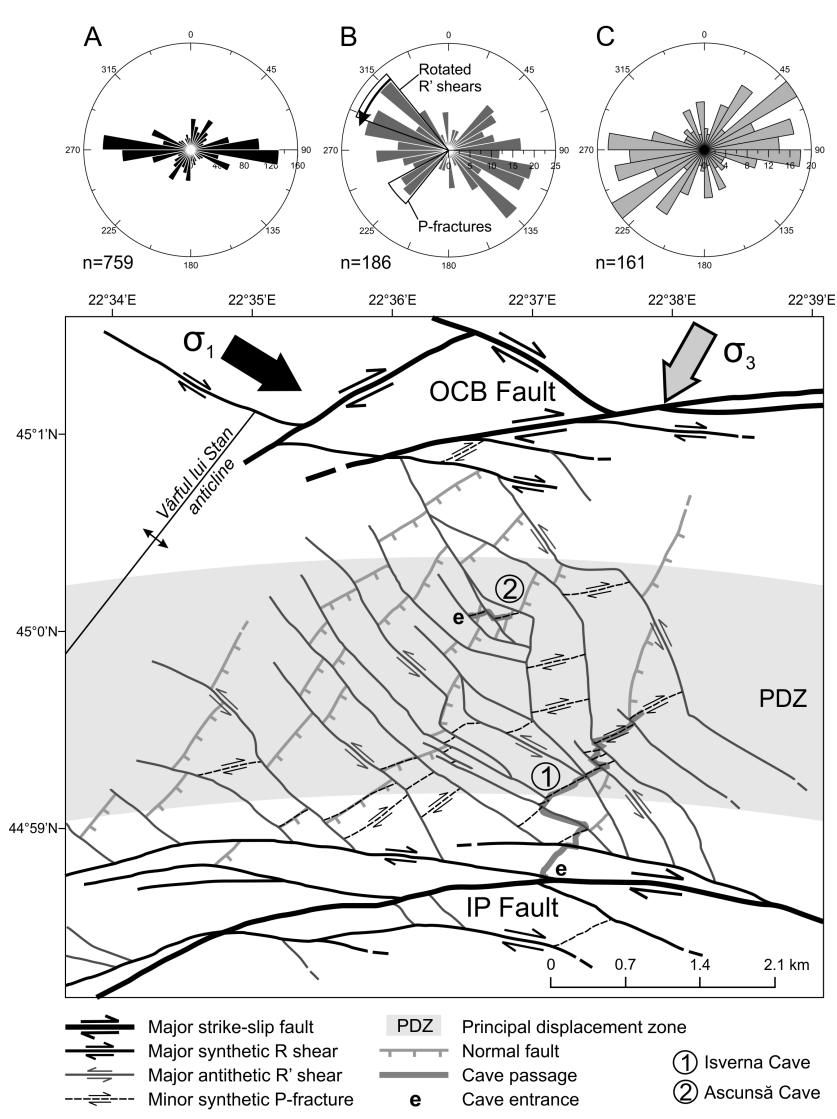

Fig. 2. Strike-slip tectonics and cave development in the Mehedinți Mts, showing comparative orientations for joints (A), faults and fractures (B) and cave passages (C). Isverna Cave survey data provided by Z. Gyurka, 2000 (unpublished material)

- The limestone bedrock forms the basal layer of the Cerna Nappe, emplaced during the Intra-Senonian tectogenesis (Late Cretaceous) by overthrusting the argillaceous ductile matrix of the Coșuștea Nappe mélange. Ascunsă Cave is a typical contact cave developed along the décollement.

- Eocene-Oligocene orogen-parallel extension produced large-scale normal faults in the South Carpathians. A number of faults parallel to Cerna fault cut across the Isverna hydro-structure. Tilted block faulting is not excluded. Numerous karst landforms formed along these segmented faults: sinkholes, potholes, karst valleys, and caves.

The Late Miocene tectonic phase determined the formation of W-E-oriented transcurrent faults and the related Riedel arrays and splays [9], preparing the framework for valley development and cave inception. Geomorphic diversity is particularly rich within a band comprised between the OCB and the IP faults, called the principal displacement zone (PDZ). The zig-zag pattern of the internal damage zone occurred at a later stage of the shear-zone evolution [10]. The direction of the principal 
compressive stress record $\left(\sigma_{1}\right)$ is WNW-ESE, and has changed over time due to the rotational character of the strike-slip movement. The principal minimum stress $\left(\sigma_{3}\right)$ is tensile and perpendicular on $\sigma_{1}$ (Fig. 2), and the intermediate stress $\left(\sigma_{2}\right)$ is vertical.

\section{CONCLUSIONS}

This study presents new data on the speleomorphology and development of interconnected underground conduits in the contact karst from the South Carpathians under specific lithotectonic settings.

At Ascunsă Cave, walls and ceiling provided mineralogical, mechanical and morphological evidence of the tectonic activity during the nappe emplacement and the post-dating extensional regime. Calcite slickenfibers grown on limestone slickensides and Riedel microshears show that the direction of the nappe movement was ESEWNW. The chambers formed at shear intersections mainly by mélange removal and underground collapses, whereas the narrow passages were incepted and developed along subsidiary fractures under phreatic conditions. These tubes are morphological indicators for normal faulting, as they developed only inside the dropped limestone hangingwalls.

Development of the Isverna karst system is under the primary control of the Obârșia Cloșani-Brebina and Isverna-Ponoarele dextral strike-slip faults, on the one hand, and the NE-SW-oriented normal faults related to a pre-dating orogen-parallel extension, on the other. The Riedel shears are pathways for water infiltration from the epikarst zone and organized flow at greater depths. Karst conduits developed along the R'-shears and normal faults, striking NW-SE and NE-SW to ENE-WSW, respectively. The P-fractures partly inherited the normal fault system, highly dissected and deformed by the subsequent strikeslip movements. Quaternary mountain uplift may have reactivated them. In parallel, surface karst landforms follow the same orientation pattern, having been developed along the segmented normal faults and major antithetic R' shears.

This study conducted towards a better understanding of the tectonic control exerted by the Late Cretaceous thin-skinned thrusting, orogen-parallel extension and subsequent Miocene to Quaternary deformations, acting as drivers of the karstification processes in the SW South Carpathians. We also outlined the role of contact caves in providing more evidence on fault kinematics than any other surface landforms or outcrops in mid-latitude environments.

\section{ACKNOWLEDGMENT}

We are grateful to $\mathrm{C}$. Dinu for improving remarks regarding tectonic mechanisms. We kindly thank E. Isverceanu and his family for their permanent support during the field work.

\section{REFERENCES}

[1] T. McCann, The Geology of Central Europe: Mesozoic and Cenozoic. London: Geological Society of London, 2008

[2] S. Shanov and K. Kostov, Dynamic Tectonics and Karst. Berlin Heidelberg: Springer-Verlag, 2015

[3] V. Drăgușin, M. Vlaicu, and E. Isverceanu, "Mehedinți Mountains The Cave from Mohilii Creek", in Caves and Karst Systems of Romania, B. P. Onac and G. Ponta, Eds. Berlin: Springer (in press)

[4] A. Seghedi and G. Oaie, "Sedimentology and petrography of sandstones in cover nappes in the central South Carpathians: constraints for geotectonic setting”, in Geology of the Djerdap area. International Symposium Geology, A. Grubic and T. Berza, Eds. Orșova, 1997, pp. 277-279.

[5] A. Festa, G. A. Pini, Y. Dilek, and G. Codegone, "Mélanges and mélange-forming processes: a historical overview and new concepts”, International Geology Review, vol. 52, no. 1, pp. 10-12, 2010.

[6] M. Baciu, G. Mogyorosi, V. Drăgușin, Z. Gyurka and S Storozynski, "Mehedinți Mountains: Isverna Cave", in Caves and Karst Systems of Romania, B. P. Onac and G. Ponta, Eds. Berlin: Springer (in press)

[7] G. Ponta, "Geology and dynamics of underground waters in Cerna Valley/Băile Herculane (Romania)", Carbonates and Evaporites, vol. 28, no. 1, pp. 31-39, 2013.

[8] H. Fossen, Structural Geology. Cambridge: Cambridge University Press, 2010.

[9] L. Mațenco and S. Schmid, "Exhumation of the Danubian nappes system (South Carpathians) during the Early Tertiary: inferences from kinematic and paleostress analysis at the Getic/Danubian nappes contact”, Tectonophysics, vol. 314, pp. 401-422, 1999.

[10] Y. Katz, R. Weinberger and A. Aydin. "Geometry and kinematic evolution of Riedel shear structures, Capitol Reef National Park, Utah”, J Structural Geol, vol. 26, pp. 491-501, 2004. 


\section{Considerations regarding the dynamic of the present geomorphological processes developed on the sector of

\author{
subsequent valley of the Prut river \\ Criva (Republic of Moldova)
} between Horodiştea (Romania) and}

\author{
Alin Prisăcariu \\ “Dimitrie Cantemir” College, \\ Darabani, Romania
}

\author{
Georgiana Văculișteanu \\ Department of Geography, Geography and Geology \\ Faculty \\ Alexandru Ioan Cuza University of Iaşi \\ Iași, Romania
}

\begin{abstract}
The terrain of the analyzed region brings to attention a series of shaping factors which have done nothing else but to "give birth" to new landforms. Under lithological aspect, the Plateau of Moldova spreads out on the territories of the three states: Romania, Republic of Moldova and Ukraine, presenting the same features which favour the evolution of the slope processes. This study has got the role of observing the differences between the two slopes of the Prut River, the right one which appears as an imposing cuesta, and the left one which overlays on a reverse of cuesta. More exactly, it will be tried the establishing of some correlations between the structural terrain with the associated processes and the petrographic one represented by the pseudo karstic terrain.
\end{abstract}

Keywords- cuesta; reverse of cuesta; pseudo karst; structural terrain; sculptural terrain; subsequent valley

\section{INTRODUCTION}

Terminologically speaking, the structural terrain from the surface of the Plain of Moldova and especially the one of the analyzed area, is basically non-existent, in fact existing one of sculptural particularity resulted through the selective erosion under the influence of the external shaping factors.

The subsequent valleys (Fig. 1) are characterized by their perpendicular layout on the direction of the layers fall, emphasizing an asymmetrical profile. The sector of subsequent valley, within the Romanian perimeter, between Oroftiana and Radauti Prut, on the Ukrainian one, between Novoselytsia (Noua Sulita) and Criva, and on the Moldavian one between Criva and Lipcani, surprises through the terrain of cuesta, very clearly bounded in the Romanian shore and by the processes of ravine and landslides which contributed mostly to the successive modification of the border between those three states. All this geomorphological aggregate spreads out on an area of approximately $45 \mathrm{~km}$.

\section{The GEOLOGY OF THE REgION}

„The Prut River valley crosses the Darabany Mamalyga Rise, an uplifted area”(Andreychouk, 1988, 2007) where the gypsum substrat has thickness of $24-26$ $\mathrm{m}$. From lithological point of view, the sector overlays on a loamy-marnos complex with some grezo-sandy intercalations of quaternary age, Sarmatian and Badenian. On both sides in substrat can be found a reserve of gypsum, laid down in intercalations with the clay. This fact is shown, on the right shore, by the mining operations of this material from Ivancauti, Paltinis commune and on the left shore is more obvious through the "Emil Racovita" cave. The gypsum is of Badenian age and shows up on certain sectors under the shape of some arches.The Karst from the Prut area is younger and the groundwater circulation is influenced, the water from the fountains is not drinking. (Andreychouk, Ridush, 2009).

\section{The PRESENT GeOMORPHOLOGICAL PROCESSES}

\section{A. The areolar erosion}

This is present on the vast majority of the slopes, basically being precursory to the other geomorphological processes. It is characteristic to the slopes with inclinations of 2-60. As remainings of this process we can give example o series of small ditches, results of the drippings, or areas where can be observed large whitish surfaces, the saltings. This relatively simple process leads, by acting in time, to a silting-up of the slope, which can generate early glacises. (Băcăuanu, 1980). 


\section{B. The torrential erosion}

Involves a leaking of an organized type, which shapes many trenches, ravines (Fig.2) and even streams. The last ones present a large development on the right slope, having a catchment area that can reach kilometers (1 - 10 square $\mathrm{km}$ ) and lengths up to $7 \mathrm{~km}$ on certain sectors, right along Horodistea locality (Mihăilă and Prisăcariu, 2004). have the characteristic to unfold in a prismatic shape (Băcăuanu, 1968), being, moreover, very easily erodible. These processes can be observed on a wide alignment, starting from the west of Oroftiana, very closely to the Ukrainian border, and which continues in the most of the cornices from this alignment, especially in those found along the localities Baranca, Bajura, Teioasa, Horodistea, Cuzlau and Radauti Prut. A large frequence is also shown

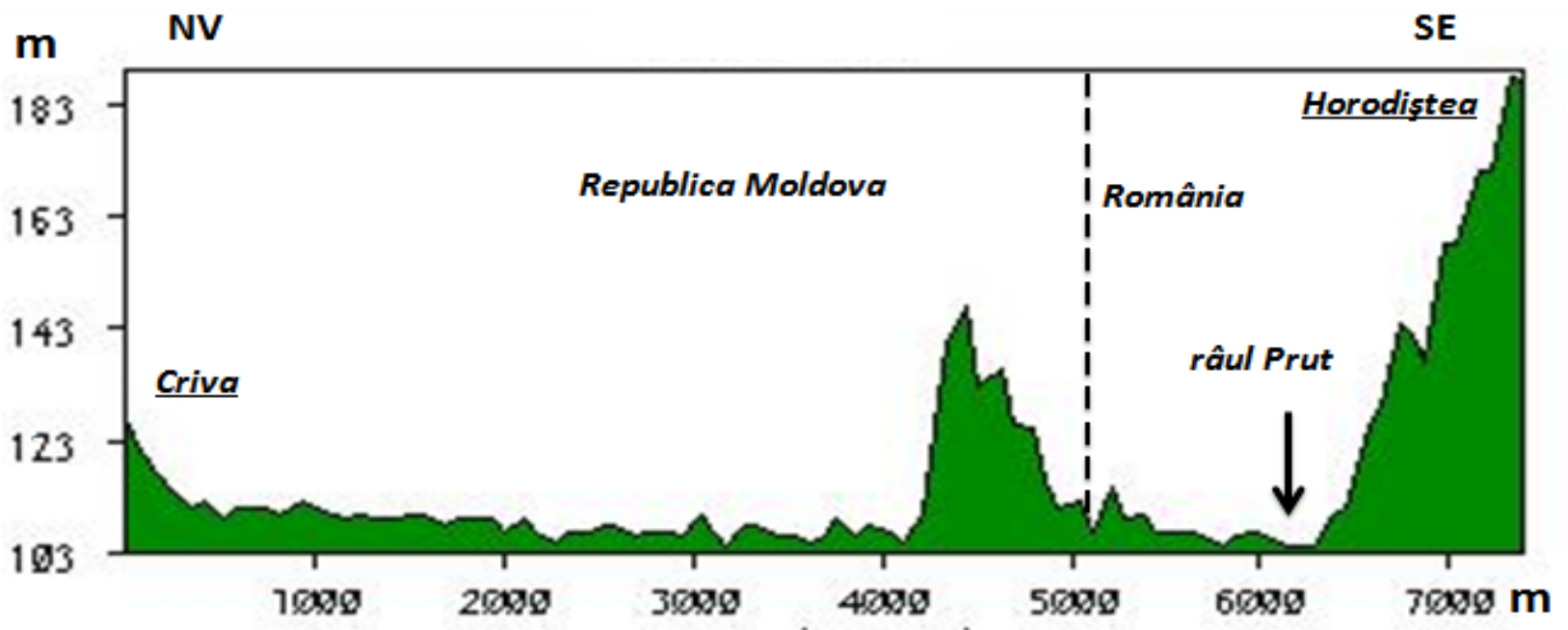

Fig. 1. Transversal profile in the subsequent Prut valley (between Criva and Horodiştea)

These organisms of erosion fall perpendicularly on the subsequent valley, generating the obsequent valleys of the region. They are young forms, found in full evolution and amaze through a huge alluvial cone which can spread up on tens of meters. The most relevant bodies of erosion can be found along the localities Bajura and Baranca, in the Hills Cetatuia Rotunda, Movila Bortoasa, Movila Iezunie, Dealul Mare and Dealul Holmului. The same situation is found in the North - the West of the locality Paltinis, in Dl. Paltinisului, Dl. Ivancauti, Dl. Cuzlau and Dl. Sloboziei. All these enroll to the cuestiform slope from the right side of the River Prut.

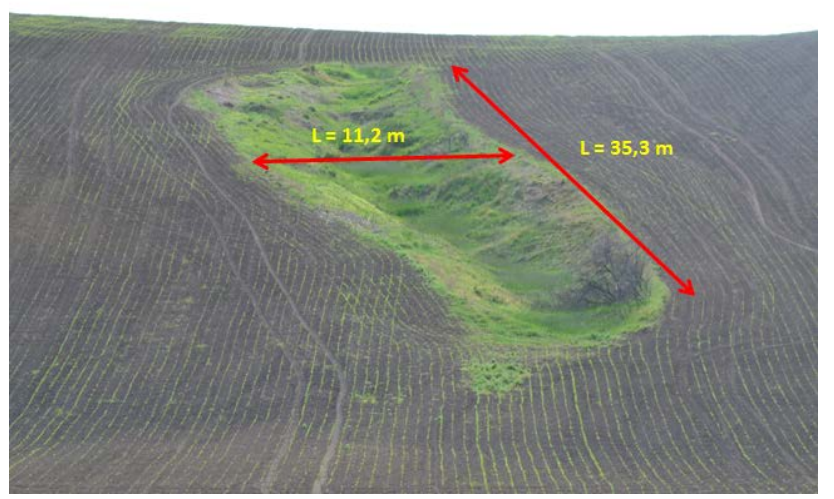

Fig. 2. Ravine, NV of Horodiştea

\section{The crumblings}

They show a relative frequency, being found mostly in the slopes of the main erosion bodies. The amplitude of this process is due mainly to the factors related to the lithological structure, such as the one of the clays which in the shores of the slopes of the valleys of obsequent kind.

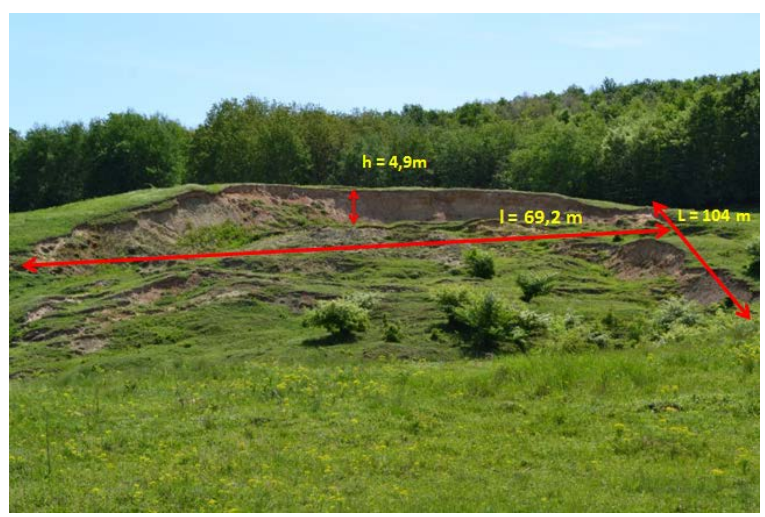

Fig. 3. Landslide NV of Păltiniş

\section{The landslides}

Affect strongly the landscape, also causing the decrease of the agricultural potential of the region had into view.

Those are mainly of mixt type (Fig.3 and 4), presenting a mixture of mounds, waves and steps, or even nests (Bojoi, 2000). Often, between the landslides waves the water stays, generating ponds which will favour the process afterwards. The cornices have heights and lengths that reach even hundreds of meters on certain alignments. The sliding bed has got here and there thicknesses of 10 $20 \mathrm{~m}$. Another relevant factor is the sliding velocity, which presents a kind of variability depending on declivity and also on the moistening degree. On certain slope sectors there is implemented a stabilization by planting some curtains of trees, but, even though, over $75 \%$ from them have got an active status.

The distribution of landslides in Moldavian Plateau is a direct consequence of the normaly contributin of natural 
factors. These ar spreaded along the cuesta fronts. ( Mărgărint and Niculiţă, 2017)

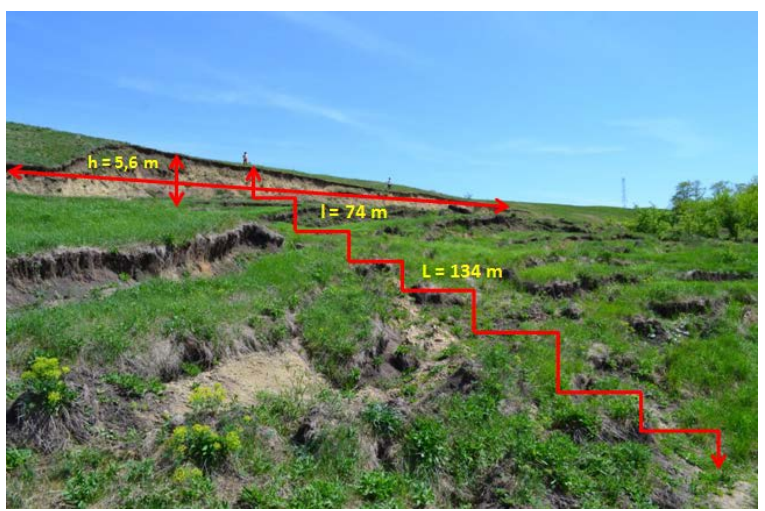

Fig. 4. Landslide NE of Horodiştea

\section{E. The suffosion}

Is the process which can be considered as precursory to the formation of the subsequent pseudo karstic terrain (Bleahu, 1974) Funnels of suffusion can be found in the north of Ivancauti and continue on certain alignments up to Radauti Prut or spread out to the north to the region analyzed in this study, correspondent to the Republic of Moldova. The pseudosuffusional processes are obvious at the upper part of the slopes, at the contact with the interfluves. These processes develops themselves mainly on loessial deposits.

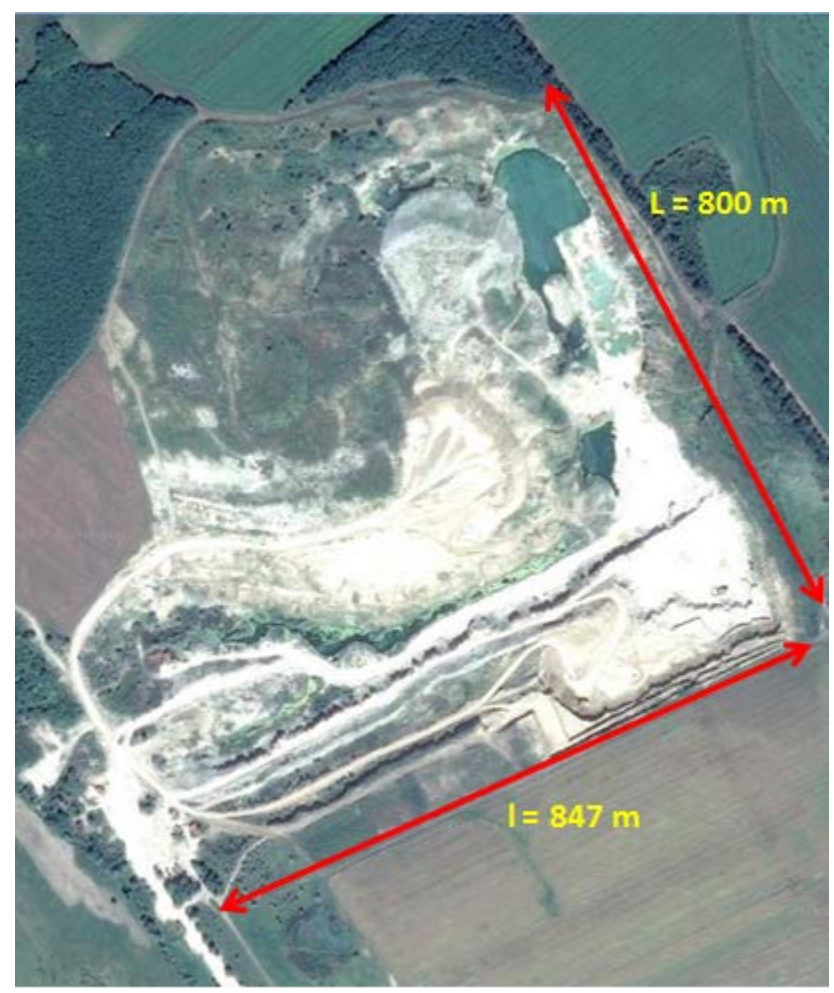

Fig. 5. Criva landscape (Google Earth).

\section{F. The pseudo karst}

"Emil Racovita" cave from Criva, county Briceni, Republic of Moldova, enrolls itself amongst the most important from Europe, being the third longest. From geomorphological point of view, there can be mentioned certain processes of surface reunified by the ones that have a subaerial evolution. The precipitation, dissolution, alteration or even the dripping being the main processes generating new forms of terrain. (Eslava et al., 2000) This cave is made up from gypsum and becomes amazing through its dimension.

It has got over 20 lakes inside, with variable dimensions. An aspect of similar importance is represented by the clay deposited on the internal walls, transported and deposited by the water course which had various fluctuations, this obviously determining different thicknesses, and especially a distinguished colouring. Its genesis is due to the erosion exercised by water, on certain sectors taking place crumblings that can block the galleries. A special feature is the sedimentation of some sectors and namely, the speleal sedimentation.

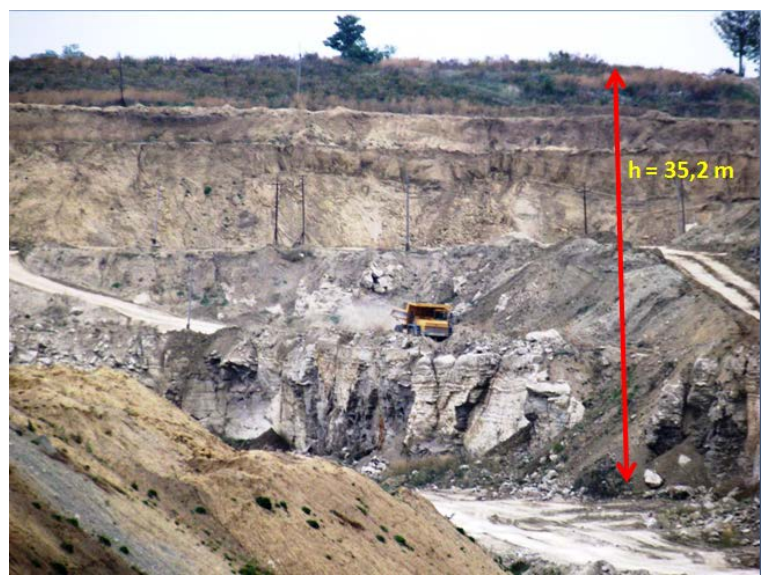

Fig. 6. Exploitation of gips resources - Criva

\section{CONCLUSIONS}

This study has got as its purpose the analysing in parallel of the two slopes of the Prut River, with the desire of underlining both the differences and the similarities. The right slope becomes original through the amplitude of the geomorphological processes, while the left one amazes through the development of a karstic terrain on gypsum. It is also impressive the difference of morphometric type between those two, apart from that morphogenetic. Thus, the structural terrain represented through the wide cuestas from the northern frame of Ibanesti Ridge, more exactly the cuestiform slope found along the locality analyzed, namely Horodistea (the northernmost point of Romania 48014'41'N) enrolls itself in the terrain through continuous shaping and subsequent generation of new and ample organisms of erosion and processes of slope. The Criva region, although poor in processes of slope, has got a real geomorphological "laboratory" (Figs 4 and 5) in the underground.

\section{REFERENCES}

[1] N. Andreychouk, Zoloushka Cave. Sosnowiec - Simpferopol, Russia, 2007.

[2] V. Andreychouk, B. Ridush, "Karstogenesis at the Prut river valley (western Ukraine, Prut area)", HipogeneSpeleogenesis and Karst Hidrogeology of Artesian basins, Ukrainian Institute of Speleology and Karstology, 2009.

[3] V. Băcăuanu, Câmpia Moldovei. Studiu geomorfologic, Edit. Acad. R.S.R., Bucureşti, 1968. (in Romanian)

[4] V. Băcăuanu, N. Barbu, M. Pantazică, Al. Ungureanu, and D. Chiriac, Podişul Moldovei - natură, om, economie, Editura Ştiinţifică şi Enciclopedică, Bucureşti, 1980. (in Romanian) 
[5] M. Bleahu, Morfologia carstică, Edit.Ştiinţifică, București, 1974 (in Romanian)

[6] I. Bojoi., România - Geografie fizică, Edit. Universităţii „Al.I.Cuza”, Iaşi, 2000. (in Romanian)

[7] J. Eslava, S. Bahamoa, and M. Romero, Clasificacion Climatica de los Karst. Meteorol. Colomb. 2:67-72. ISSN 0124- 6984.Bogota, D.C. - Colombia, 2000.

[8] D. Mihăilă and A. Prisăcariu, Câteva considerații asupra dinamicii proceselor geomorfologice actuale, pe versantul drept al văii
Prutului Între Oroftiana şi Rădăuţi Prut, Analele Universităţii „SStefancel Mare” Suceava, Secţiunea Geografie, vol. 13, pp. 33-38, 2004. (in Romanian)

[9] M.C. Mărgărint and M. Niculiță, "Landslide type and pattern in Moldavian Plateau, NE Romania", in Landform Dynamics and Evolution in Romania, M. Rădoane and A. Vespremeanu-Stroe, Eds. Springer, 2017, pp. 271-304. doi:10.1007/978-3-319-325897_12 


\title{
An approach to investigate the effects of climate change on landslide hazard at a national scale (Romania)
}

\author{
Marta Jurchescu, Dana Micu, Mihaela Sima, \\ Dan Bălteanu, Carmen Dragotă, Mihai Micu \\ Institute of Geography, Romanian Academy (IGAR) \\ Bucharest, Romania \\ marta_jurchescu@yahoo.com
}

\author{
Roxana Bojariu, Alexandru Dumitrescu \\ National Meteorological Administration (ANM) \\ Bucharest, Romania \\ bojariu@meteoromania.ro
}

\author{
Francisc Senzaconi \\ General Inspectorate for Emergency Situations (IGSU) \\ Bucharest, Romania \\ senzacof@mai.gov.ro
}

\begin{abstract}
It is widely recognized that climate change is affecting slope stability. However, there is still a great knowledge gap on landslide-climate interaction, while in data-scarce regions, like Romania, it is even less clear how landslide occurrence probability will evolve in response to climate change. The present study proposes a methodological framework for assessing the potential effects of climate change on landslide hazard at a national scale, under current (1961-2015) and future climate (2021-2050). The research approach for developing landslide hazard scenarios relies on the historical landslide inventory of the General Inspectorate for Emergency Situations (IGSU) (20052015), updated observational meteorological data and EUROCORDEX projections of six GCM-RCM runs under two new IPCC scenarios (RCP4.5 and RCP8.5). Precipitation observation and projection data are analyzed in close relation to the landslide events reported within the historical landslide inventory, in order to develop national rainfall-induced landslide hazard scenarios. Maps displaying projected climate change impacts upon landslide hazard patterns and levels are constructed. Future climate-driven evolution trends on landslide occurrences are identified and discussed. Their understanding is expected to support landslide risk management at both national and regional scales. The study was conducted in the framework of the RORISK “Disaster Risk Evaluation at National Level” project, aimed to support the fulfillment of the EU ex-ante conditionality 5.1, co-financed under the European Social Fund through the Operational Program Administrative Capacity 2014 - 2020 and coordinated by IGSU.
\end{abstract}

Keywords-landslide hazard; climate change impact; national scale; extreme climate indices; Romania

\section{INTRODUCTION}

It is generally acknowledged that climate change has implications on slope stability and landslide hazard and that this influence can manifest itself at various spatial and

This study was developed in the framework of the RO-RISK project (“Disaster Risk Evaluation at National Level”, SIPOCA code: 30, 2016), coordinated by the Romanian General Inspectorate for Emergency Situations (IGSU) and co-financed by the European Social Fund through the Operational Program for Administrative Capacity (POCA). temporal scales [e.g. 1, 2, 3]. Over the recent years, studies devoted to this topic have been increasing continuously, however at a rate which is lower than the one of the total landslide literature [4]. A series of aspects regarding the location, extent, magnitude or the course of the induced changes remain unclear [2, 4]. Hence, there is a continuing need to understand how climate change will affect landslide occurrence and associated hazards and risks.

Precipitation is one of the most common trigger of landslides [5, 6], but landslide-climate interactions have a great specificity, which generally relies on local physicalgeographical settings. Although it is recognized that Romania represents one of the landslide hotspots on the European map $^{[1]}$ and that landslides are mainly triggered by heavy rainfall or rainfall overlapping snowmelt, there were only very few attempts to relate landslide occurrences in Romania to climate and particularly rainfall. The studies were usually restricted to single sites or areas of small extents and selected rainfall events and only a few implied spatial analyses [a review in $7 ; 8$ ]. A first effort to understand the impact of a changing climate on the evolution of landslide hazard at regional level has been done in the frame of the FP7 ECLISE project $^{[2]}$ [9]. However, a nation-wide overview on the expected effects of climate change on landslide hazard and risk on the Romanian territory is still lacking.

The RO-RISK (Disaster Risk Evaluation at National Level) project was undertaken in 2016, being coordinated by the General Inspectorate for Emergency Situations (IGSU) and co-financed by the EU through the European Social Fund in the frame of the Operational Program Administrative Capacity 2014 - 2020. Focusing on assessing the specific hazards and risks occurring on the Romanian territory, the project was

\footnotetext{
${ }^{1}$ http://www.changes-itn.eu

${ }^{2}$ http://www.eclise-project.eu
} 
aimed at strengthening risk prevention and management in the country. It provided, among others, the framework for assessing landslide hazard and risk at the national level. The current paper presents some preliminary results achieved within the RO-RISK project regarding the development of a methodological framework for evaluating the potential impacts of climate change on landslide hazard at a national level, by utilizing future climate projections and a landslide hazard scenario design.

\section{Climate DAta ANALysis}

Gridded precipitation information provided by the National Meteorological Administration (ANM), derived from both meteorological observation records (1961-2015) and climate projections (2021-2050), were used to analyze past periods of landslide occurrence and to model precipitation-driven landslide hazard at a national scale. The landslide preparing/triggering role of precipitation was expressed by means of six precipitation extremes indices - 10year and 100-year return values of 3-day precipitation, wet spell length and seasonal rainfall. These were selected from a more extended list of precipitation extreme indices computed for different return periods (5, 10, 30, 50, 100 and 1000 years), in order to comply with the project's requirements and because they were considered suitable for landslide occurrence. The selected precipitation extreme indices were used to develop national landslide hazard scenarios, under both current and future climatic conditions. Information on future extreme precipitation was derived from the projections of a selection of six EURO-CORDEX GCM-RCM simulations (Table I) available at a horizontal resolution of $12.5 \mathrm{~km}$ (and downscaled at $1 \mathrm{~km}$ ), most reliable in reproducing the current climatic conditions [10]. The selected six models performed under IPCC emission scenarios RCP4.5 and RCP8.5. From this selection, the projections of two GCM-RCM runs have been particularly considered when analyzing landslide hazard under a wetter (IPSL-INERIS-WRF331F) and a drier (KNMIRACMO22E) future climate.

TABLE I. SELECTED EURO-CORDEX CLIMATE MODELS FOR ASSESSING FUTURE LANDSLDIE HAZARD IN ROMANIA [10]

\begin{tabular}{|c|c|c|c|}
\hline \multirow[t]{2}{*}{ No. } & \multicolumn{3}{|c|}{ EURO-CORDEX climate projections } \\
\hline & Regional climate model centers & $\begin{array}{l}\text { Regional } \\
\text { climate model } \\
(\mathrm{RCM})\end{array}$ & $\begin{array}{c}\text { Global } \\
\text { climate model } \\
(G C M)\end{array}$ \\
\hline 1 & $\begin{array}{ll}\text { CLMcom } & \text { (CLMcom } \\
\text { Consortium) } & \\
\end{array}$ & CLM 4-8-17 & $\begin{array}{l}\text { MPI-ESM- } \\
\text { LR }\end{array}$ \\
\hline 2 & $\begin{array}{l}\text { DMI (Dansih Meteorological } \\
\text { Institute) }\end{array}$ & HIRHAM5 & $\begin{array}{l}\text { ICHEC-EC- } \\
\text { EARTH }\end{array}$ \\
\hline 3 & $\begin{array}{l}\text { IPSL-INERIS (Laboratoire } \\
\text { des Sciences du Climat et de } \\
\text { l'Environnement, IPSL, } \\
\text { CEA/CNRS/UVSQ - Institut } \\
\text { National de l'Environnement } \\
\text { Industriel et des Risques) }\end{array}$ & WRF 331F & $\begin{array}{c}\text { IPSL- } \\
\text { CM5A-MR }\end{array}$ \\
\hline 4 & $\begin{array}{l}\text { KNMI (Royal Netherlands } \\
\text { Meteorological Institute) }\end{array}$ & $\begin{array}{l}\text { RACMO } \\
22 \mathrm{E}\end{array}$ & $\begin{array}{l}\text { ICHEC-EC- } \\
\text { EARTH }\end{array}$ \\
\hline 5 & $\begin{array}{l}\text { MPI-CSC (Max-Plank } \\
\text { Institute for Meteorology - } \\
\text { Climate Service Center) }\end{array}$ & REMO 2009 & $\begin{array}{l}\text { MPI-ESM- } \\
\text { LR }\end{array}$ \\
\hline 6 & $\begin{array}{lr}\text { SMHI } & \text { (Swedish } \\
\text { Meteorological } & \text { and }\end{array}$ & RCA4 & $\begin{array}{l}\text { ICHEC-EC- } \\
\text { EARTH }\end{array}$ \\
\hline
\end{tabular}

\begin{tabular}{|l|l|c|c|}
\hline \multirow{2}{*}{ No. } & \multicolumn{3}{|c|}{ EURO-CORDEX climate projections } \\
\cline { 2 - 4 } & Regional climate model centers & $\begin{array}{c}\text { Regional } \\
\text { climate model } \\
\text { (RCM) }\end{array}$ & $\begin{array}{c}\text { Global } \\
\text { climate model } \\
\text { (GCM) }\end{array}$ \\
\hline & Hydrological Institute) & & \\
\hline
\end{tabular}

\section{Assessing the EFFect of Climate Change ON} LANDLSIDE OCCURRENCES

A nation-wide database of recent historical damaging landslides, integrated and provided by IGSU, was used to investigate the relation between landslide occurrences and climate. The information was recorded by the civil protection county inspectorates and covers the 2005-2015 time interval. The database comprises over 3700 records distributed across 31 counties. However, the data is believed to have a heterogeneous character in terms of location and temporal accuracies and completeness.

The recent historical landslide data enabled to retrieve the rainfall indicator values (seasonal rainfall, intervals of consecutive wet days, 3-day precipitation) corresponding to landslide occurrences. In order to remove possible biases affecting this relationship, mainly due to the vertical zonation of climatic parameters as well as to the different local climatic influences present on the Romanian territory, rainfall variables were normalized with the mean annual precipitation and the rainy-day-normal. The analysis of past events was aimed at establishing a relation between the normalized rainfall values and the extent of the geomorphic response in terms of the number of slope failures. The triggering effect of precipitation has been shown to vary with terrain predisposing conditions, i.e. for landslides to initiate in less susceptible regions higher rainfall quantities are needed than those associated to landsliding at the most susceptible slopes. Therefore, a susceptibility zonation of the Romanian territory was first required in order to separate among areas having different geological, topographic and land-use conditions [11].

This type of analysis, accounting for regional and temporal variability of the main factors involved in hazard analysis (spatial probability, intensity of the trigger, response magnitude), allowed to maximize the use of the rather reduced volume of landslide data considered both accurate and complete and limited to the territories of only a few counties. Therefore, a relationship established on a limited area of the country could be extrapolated to the rest of the country's territory by considering the differences induced by morphostructural, lithological and meteorological settings.

Hazard scenarios were built by overlaying the slide susceptibility map with several other maps displaying the triggering potential of the selected rainfall variables. The triggering potential was achieved by normalizing the climate parameter maps in the same way as for investigating past climate-landslide relations. The overlay procedure was controlled by means of semi-quantitative hazard matrices (susceptibility $x$ triggering potential).

The main limitations of the present research are caused by the quality of the landslide database, in terms of spatial and temporal incompleteness and heterogeneity of registration accuracies. In this context, knowledge derived on the climate- 
landslide relation was not regarded as having any statistical significance. It was merely used to modulate the expert-based hazard scenario matrices.

\section{PRELIMINARY RESUltS AND CONCLUSIONS}

Analyzing the impact of climate on landslide hazard is the most appropriate way when aiming to understand climate effects on landslide occurrence at regional/national scales. This study resulted in the construction of several national rainfall-induced landslide hazard maps. Comparisons between reference and future maps depicting landslide hazard in response to different extreme climate indices revealed some trends to be attributed to climate change. Spatial distribution of landslide hazard is mainly dictated by terrain attributes, especially lithology, and thus most affected are the hilly and plateau regions built of Neogene deposits and the mountainous regions developed on Cretaceous and Paleogene flysch. However, variations in hazard magnitude across these regions for a particular analyzed frequency are expected to be due to variations in the triggering factor.

Future change in seasonal rainfall is expected to induce, under both RCPs, slight increases of landslide activity mainly in the Eastern Carpathians, the Moldavian Subcarpathians and the northern part of the Moldavian Tableland, in case of the 10 -year return period, and extensive increases particularly in the western hilly and plateau areas, in case of the 100-year return period. Decreases in the number of landslides are also possible in the south-western part of Romania. Landslide hazard triggered by short-term, 3-days precipitation indicates an increase in the number of landslides affecting different parts of the Transylvanian area, the Subcarpathian hills and the Moldavian plateau in case of a 10-year recurrence period. When considering a 1/100years frequency, landslide hazard is expected to intensify under the future evolution of highintensity and short-duration precipitation and extend towards the north-eastern part of the country as well as towards the Eastern and the Curvature Carpathians, according to both RCPs. As for future variations in the length of wet intervals associated to a $1 / 10$ years frequency, these are expected to result in more abundant landslide occurrences in the Eastern Carpathians, and possibly in the Apuseni Mountains, parts of the Transylvanian Plateau and the Eastern part of the country (i.e. the Moldavian Plateau and the Moldavian Subcarpathians). Decreases in the landslide activity are also possible, e.g. in areas of the Moldavian Plateau or in the south-western part of the country.

Generally, if considering one trigger proxy as simulated by one single model, landslide hazard increases seem to be more extensive under RCP8.5 than under RCP4.5.

As is the case of any climate-landslide study, several types of epistemic and aleatory uncertainties also affect the current approach and they are related to the main steps of the study: assessment of landslide susceptibility, determination of climate-landslide interactions and relationships, elaboration of landslide hazard maps, future climate modeling and climate data processing, construction of future climate-driven landslide hazard scenarios.
In the context of an undisputable climate warming, expected to affect landslides, this paper proposes a conceptual framework to address the effects of climate change on landslide hazard at a national scale. It provides a first evaluation on the future climate-landslides relation for the national territory of Romania, which, at the same time, represents one of Europe's hotspot areas in terms of landslides. The developed approach allows users to gain a general and rapid appraisal of the projected future climate impacts on landslide occurrence at the national level.

However, given the high uncertainties affecting climatelandslide investigation frameworks, care is recommended when interpreting the expected variations in landslide hazard driven by projected climate change. Future work will aim both at reducing as much as possible existing uncertainties - e.g. by improving the quality of the various input data used and by a more in-depth analysis of the climate-landslides relationship as the basis for understanding future climate impacts - and at quantifying and communicating those uncertainties which will remain inevitable.

\section{ACKNOWLEDGMENT}

The authors wish to thank the IGSU institution, for the good coordination of the RO-RISK project and their continuous support, as well as the other partner institutions involved in the landslide research: the Technical University of Civil Engineering (UTCB), the National Institute for Research and Development in Constructions, Urban Planning and Sustainable Spatial Development (URBAN-INCERC) and the National Institute for Earth's Physics (NIEP). They also express their appreciation to the entire team of personnel involved in the different parts of the study.

\section{REFERENCES}

[1] R.C. Sidle and H.Ochiai, "Landslides: processes, prediction, and land use”. Water Resour. Monogr., vol. 18. Washington DC: AGU, 2006, 312 pp.

[2] M.J. Crozier, "Deciphering the effect of climate change on landslide activity: a review”, Geomorph., vol. 124, pp. 260-267, 2010.

[3] J.A. Coe and J.W. Godt, "Review of approaches for assessing the impact of climate change on landslide hazards", in Landslides and Engineered Slopes, Protecting Society Through Improved Understanding: Proceedings 11th International and 2nd North American Symposium on Landslides and Engineered Slopes, E. Eberhardt, C. Froese, A.K. Turner, S. Leroueil, Eds. Banff, CA: Taylor \& Francis Group, June 2012, pp. 371-377.

[4] S.L. Gariano and F. Guzzetti, „Landslides in a changing climate”, EarthSci. Rev., vol. 162, pp. 227-252, 2016.

[5] M. Crozier, "Landslides: causes, consequences and environment". London: Croom Helm, 1986, 252 pp.

[6] J. Corominas, "Landslides and climate”, CD-Rom. Cardiff, UK., 33 pp., 2001 [Keynote Lectures, 8th Intern. Symp. on Landsl., 2000]

[7] M. Micu, M. Jurchescu, I. Șandric, M.C. Mărgărint, Z. Chițu, D. Micu, R. Ciurean, V. Ilinca, and M. Vasile, "Mass Movements", in Landform Dynamics and Evolution in Romania, M. Rădoane and A. VespremeanuStroe, Eds., Springer, 2017, pp. 765-820.

[8] Z. Chiţu, T. Bogaard, A. Busuioc, S. Burcea, I. Țandric, and M.-J. Adler "Identifying hydrological pre-conditions and rainfall triggers of slope failures at catchment scale for 2014 storm events in the Ialomita Subcarpathians, Romania”, Landslides, vol. 14, pp. 419-434, 2017. 
[9] M. Jurchescu et al., unpublished.

[10] R. Bojariu et al., Schimbările climatice - de la bazele fizice la riscuri și adaptare. București: Printech, 2015, 200 pp. (in Romanian)
[11] D. Bălteanu et al., unpublished. 
Part III - Fieldtrips 



\title{
Hadâmbu sector of Iași cuesta escarpment - recent mass movement processes and deforestation
}

\author{
Mihai Ciprian Mărgărint, Mihai Niculiță, Silviu Doru \\ Department of Geography, Faculty of Geography and Geology \\ Alexandru Ioan Cuza University of Iaşi \\ Iaşi, Romania \\ mihai.niculita@uaic.ro, margarint.ciprian@yahoo.com
}

\section{INTRODUCTION}

The Moldavian Plateau is one of the most representative hilly area and one of the regions most affected by mass movement processes from Romanian. A recent regional historical landslide inventory [1] showed that the general pattern of landslide distribution emphasizes a repetitive model along cuesta scarp slopes. This pattern is related to the lithology and landforms as preconditioning factors. The lithology of the area is dominated by caprocks of limestones, sandstones, and volcanic consolidated tuffs over friable clayey and sandy strata intercalations [1].

The contact between the Central Moldavian Plateau and the Jijia Hills, known as Iaşi cuesta escarpment exhibit the mentioned landform, lithologic and structural pattern, being one of the areas of the Moldavian Plateau where the landslide density is the highest [1]. At the edge of the Central Moldavian Plateau the Upper Bessarabian limestone and sandstone layers known as Repedea Limestone Formation, overlay the Medium Bessarabian clayey and sandy layers known as Cryptomactra Clays Formation [2, 3].

\section{LANDSLIDES FROM HADÂMBU SECTOR}

In the Hadâmbu sector of the Iaşi cuesta escarpment the old landslides were reactivated by recent deforestation and slope cutting for road construction (Figs 1 and 2). This sector illustrates better the effect of land use and anthropic preparatory factors. The landslide reactivations were triggered by heavy rainfalls which overlapped with the snowmelt, and in general happened during March-April interval.

In the last few years, these dense reactivations of old landslides created major dysfunctions for the local communities, despite major investments in road repair.

For the road sector that climb this part of Iaşi Cuesta (between Hadâmbu village and Hadâmbu Monastery DC49), in 2009 around 2 million of RON were invested for the rehabilitation of the damages induced by previous reactivations. Five years later, the reactivation of the old landslide affected again the road after a spring rainy period. The same situation was recorded in March this year a few kilometers to the west in the Voineşti sector of Iaşi cuesta escarpment.

The deforestation along this sector (Figs 3 and 4) happened between 1890 and 1920 .

\section{CONCLUSIONS}

Considering the presented situation we argue that by continuing to invest only in the road infrastructure after landslide induced damages, the history will repeat, especially if future rainy period will emerge. The only chance to provide a long term solution is to study in depth the hydrogeological conditions of the site and to invest in technical drainage infrastructure and reforestation.

\section{ACKNOWLEDGMENT}

We are grateful to Prut-Bârlad Water Administration who provided us with the LIDAR data. We have used the computational facilities given by the infrastructure provided through the POSCCE-O 2.2.1, SMIS-CSNR 13984-901, No. 257/28.09.2010 Project, CERNESIM (L4).

\section{REFERENCES}

[1] M.C. Mărgărint and M. Niculiţă, "Landslide type and pattern in Moldavian Plateau, NE Romania”, in Landform Dynamics and Evolution in Romania, M. Rădoane and A. Vespremeanu-Stroe, Eds., Springer, 2017, pp. 271-304. doi:10.1007/978-3-319-32589-7_12

[2] M Brânzilă, Geologia părţii sudice a Câmpiei Moldovei. Iaşi: Editura Corson, 1999. (in Romanian)

[3] L. Ionesi, B. Ionesi, V. Roşca, A. Lungu, and V. Ionesi, Sarmatianul mediu și superior de pe Platforma Moldovenească. București: Editura Academiei Române, 2005. (in Romanian) 


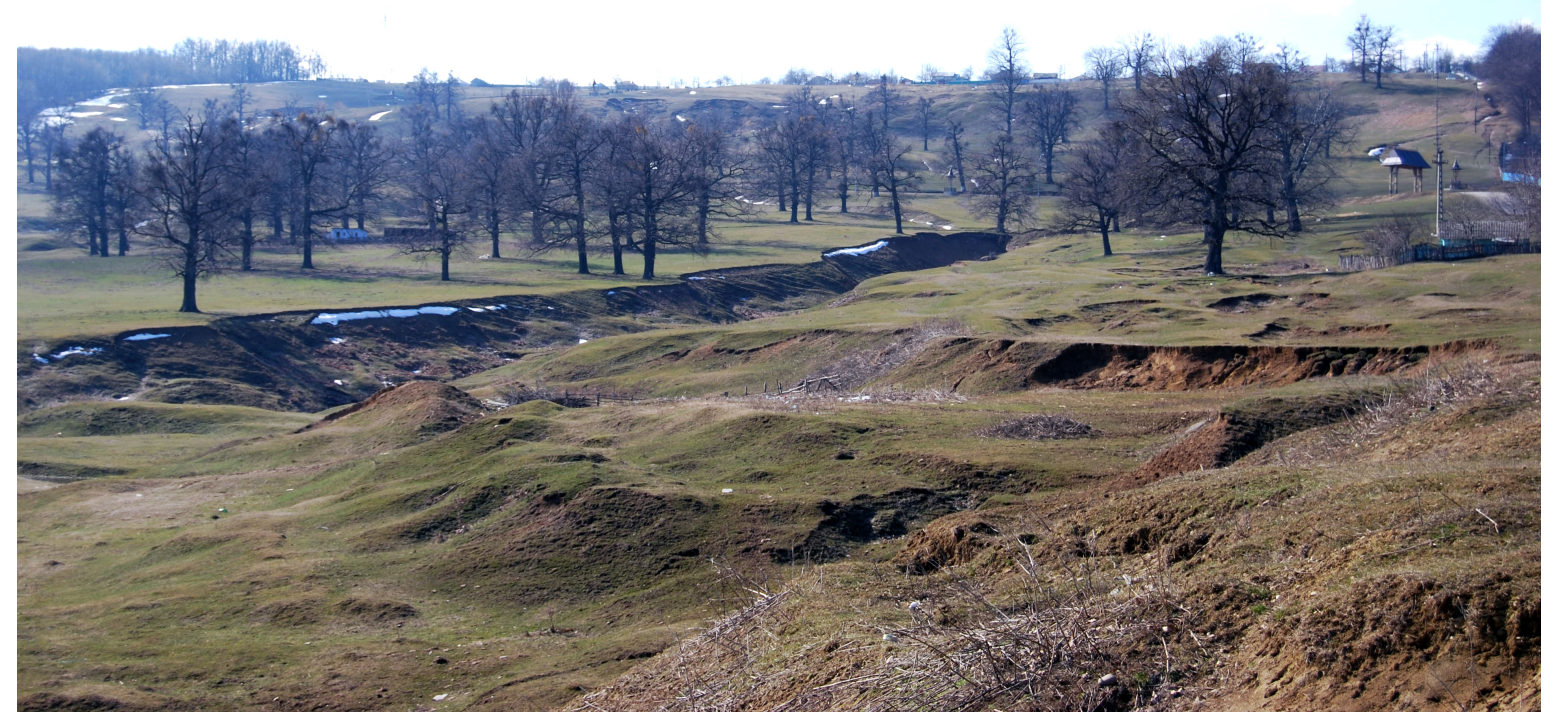

Fig. 1. General view on the deforested slope between Hadâmbu village and Hadâmbu Monastery.

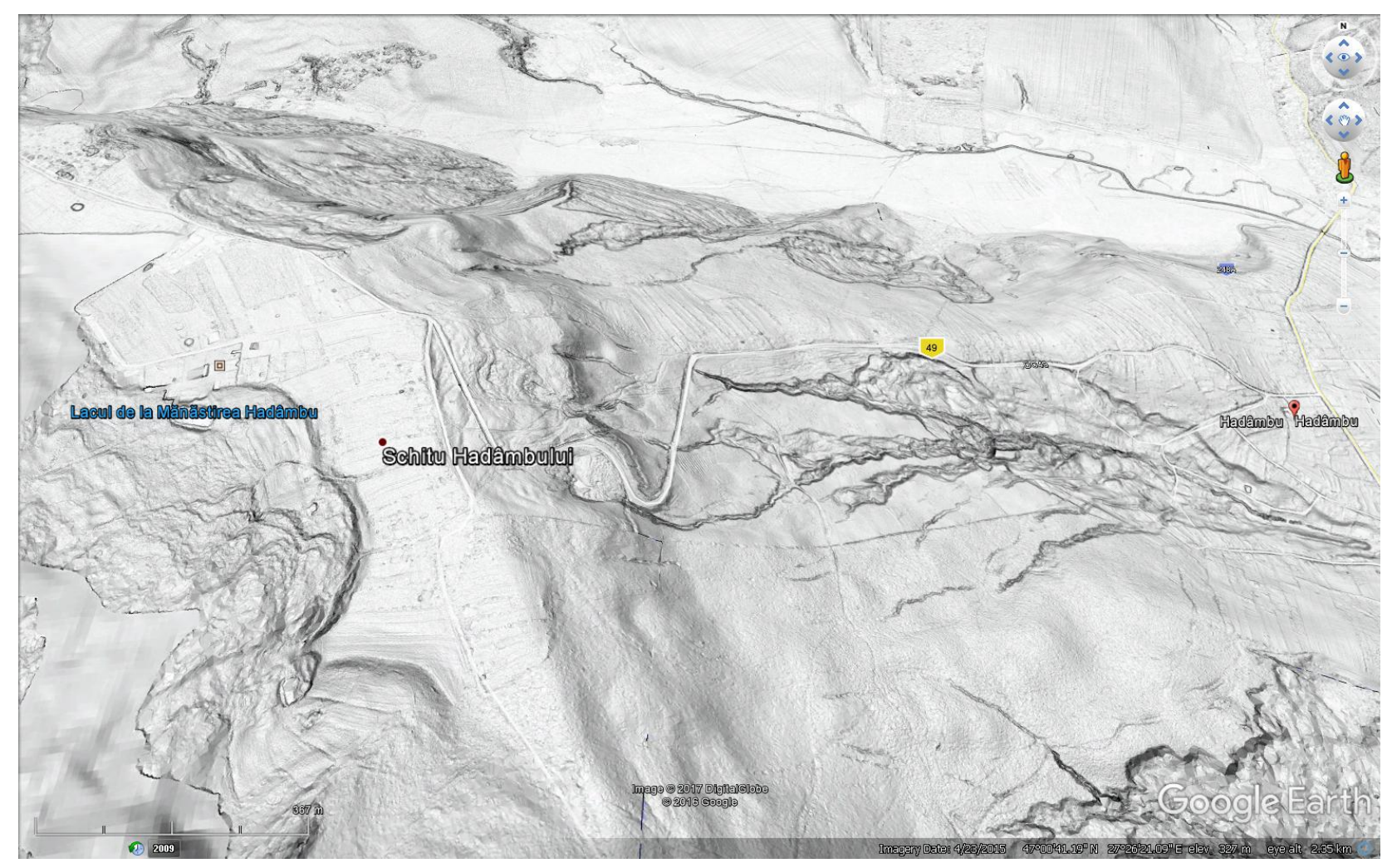

Fig. 2. LiDAR shading image of the slope between Hadâmbu village and Hadâmbu Monastery. 


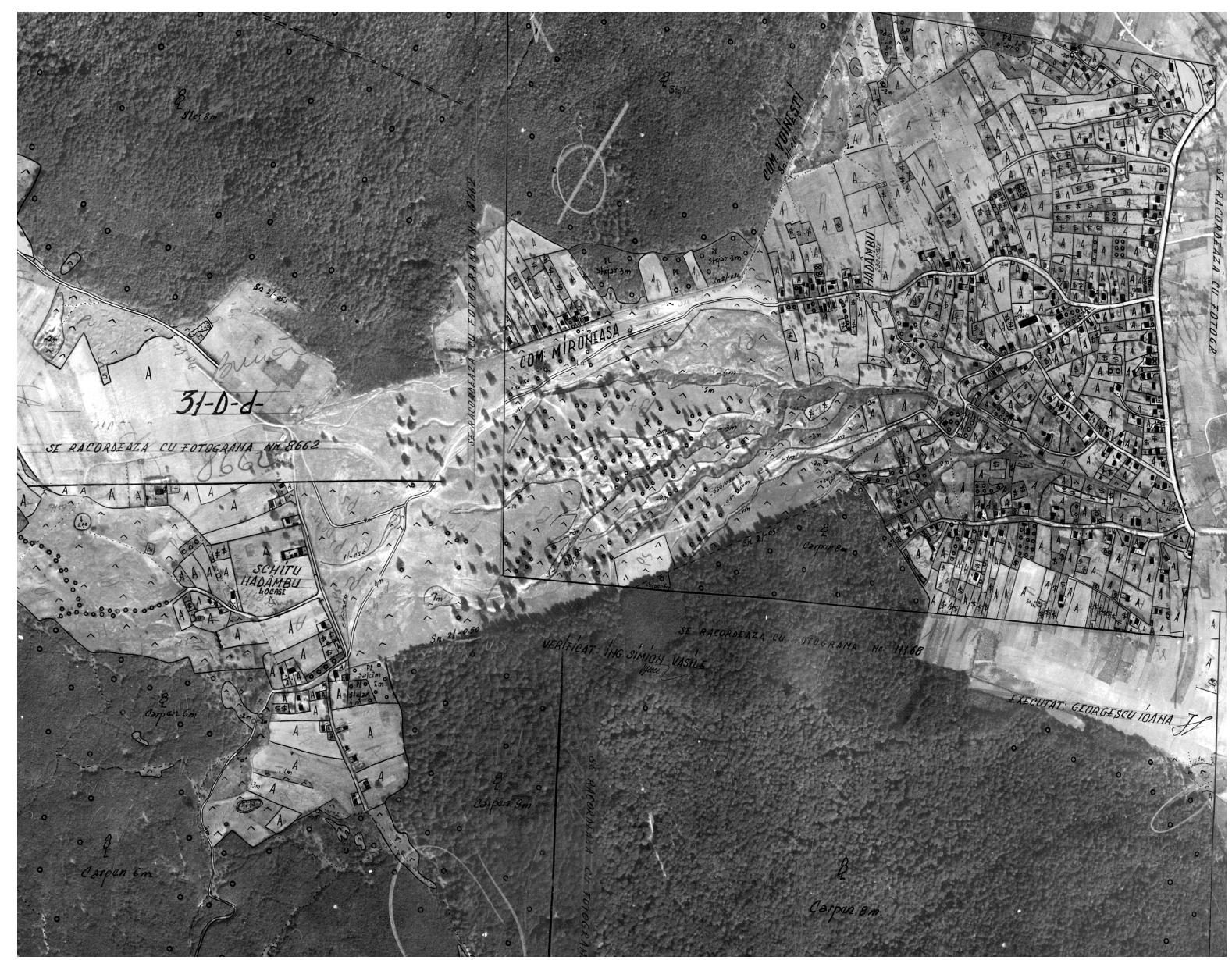

Fig. 3. Aerial image of the slope between Hadâmbu village and Hadâmbu Monastery (1971).

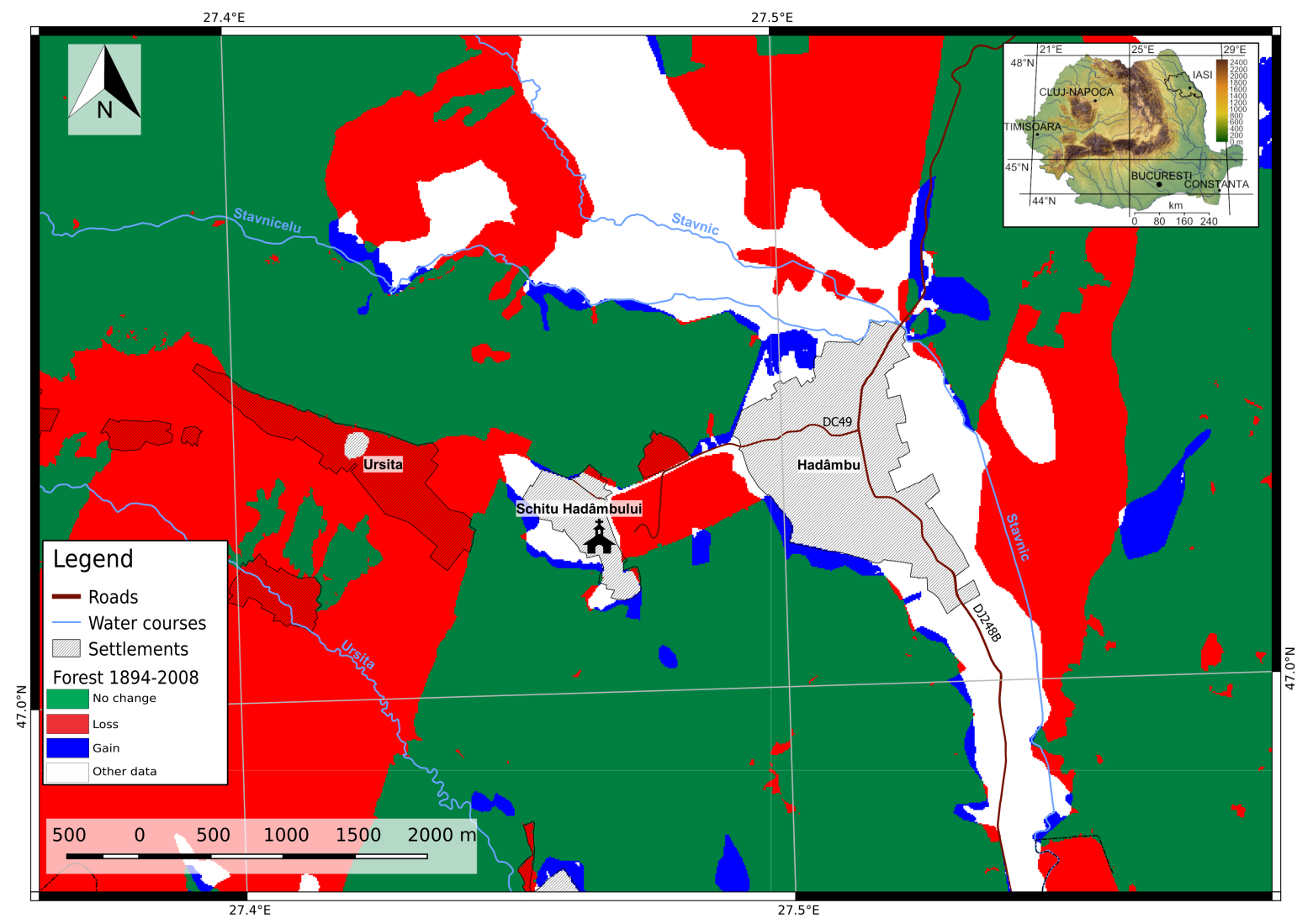

Fig. 4. Forest evolution around Hadâmbu village according to topographic sources (Moldavian Atlas 1:50 000 - 1890, Army Plans 1:20 000 - 1920, Ist and IInd ed. of 1:25 000 topographic maps - 1960 and 1984, aerial imagery - 2008). 


\section{Relict landslides, fluvial landforms and threatened geoheritage - Costești village}

\author{
Mihai Niculiță, Mihai Ciprian Mărgărint \\ Department of Geography, Faculty of Geography and \\ Geology \\ Alexandru Ioan Cuza University of Iaşi \\ Iaşi, Romania \\ mihai.niculita@uaic.ro,margarint.ciprian@yahoo.com
}

\author{
Ionuţ Cristea \\ Department of Geography \\ Faculty of Geography and History \\ Ştefan cel Mare University of Suceava \\ icristea@atlas.usv.ro
}

\section{INTRODUCTION}

The Moldavian Plateau is a landslide prone region located in North-Eastern and Eastern Romania, the general morphostructural setting of this area consisting of a monocline with cuesta landforms [1]. In the study area, the landslides are characterized by a strong temporal and spatial clustering, being influenced by the morphostructural setting and by the stratified layered rocks. The majority of the hillslopes affected by landslides are characterized by the presence of large old, relict landslides whose morphological signature is degraded by erosion and by younger landslides, the majority of them generating the retreat of the scarps in a retrogressive manner.

The topological relations between several large landslides and archaeological sites for nine selected settlements in the Moldavian Plateau, situated on ridges and hillslopes were studied by [2]. Landslides and archaeological sites were mapped using high resolution LiDAR DEMs and extensive field validation activities were performed for stratigraphic and morphologic recognition, of the landslides, deposits and archaeologic sites relations.

The investigated complex landslides are associated with chalcolithic settlements which are in topologic relations that prove the pre-chalcolitic age of the landslide initiation. While it is clear that post chalcolithic evolution of these landslides involved reactivations and retrogressive patterns, [3] argue that the initial landslide events were triggered in an period when the climatic conditions were completely different than the chalcolithic times, and even, a certain amount of time has passed, since the chalcolithic population used the landslide scarps as defensive measure of protection. The single period that could have the climatic characteristic to generate such big magnitude landslide events is the Upper Pleistocene and its boundary with the Holocene, when the changing climatic conditions could be the trigger for landslides. Giving this context, we state the need of absolute dating, in order to better frame the temporal extension of the landslide activity trough the Upper Pleistocene to Lower Holocene.

\section{CosteșTi Geoheritage Site}

Costeşti - Cier site (Figs 1, 2 and 3) is located in the Bahluieț floodplain on a relict landslide deposit, that comes from failures of both sides of the valley, that possibly blocked the Bahluiet river and nowadays is eroded by Bahluieț river, the morphology being of a terrace remnant. The oldest levels of population of the site is Cucuteni A (6550-5650 y BP). The landslide deposit is covered by a loamy deposit, which is a terrace deposit, overlayed by a paleosoil, and the archaeological remains (Figs 3b and 4). Such a sequence not only is evidence that the landslide is older than the settlement, but older than the Bahluiet, river incision and the loamy floodplain deposition event, which in turn occurred before the formation of a $\sim 30 \mathrm{~cm}$ thick soil. Since the initial failure, the landslide evolved in a retrogressive manner (Fig. 1).

The stratigraphy of the site was interpreted using a 2D ERT scan and the bank stratigraphic section (Figs 3b and 4).

The geoheritage site status was argued by [4] and the actual state of the site represents a typical case of geoheritage sites at risk, in the last 80 years half of the initial site being eroded by the Bahluieț river (according to aerial imagery and local information).

\section{ACKNOWLEDGMENT}

We are grateful to Prut-Bârlad Water Administration who provided us with the LIDAR data. We have used the computational facilities given by the infrastructure provided through the POSCCE-O 2.2.1, SMIS-CSNR 13984-901, No. 257/28.09.2010 Project, CERNESIM (L4).

\section{REFERENCES}

[1] M.C. Mărgărint and M. Niculiţă, "Landslide type and pattern in Moldavian Plateau, NE Romania”, in Landform Dynamics and Evolution in Romania, M. Rădoane and A. Vespremeanu-Stroe, Eds., Springer, 2017, pp. 271-304. doi:10.1007/978-3-319-32589-7_12

[2] M. Niculiță., M.C. Mărgărint, and M. Santangelo, “Archaeological evidence for Holocene landslide activity in the Eastern Carpathian lowland”, Quaternary International, vol. 415, pp. 175-189, 2016.

[3] M. Niculiță., M.C. Mărgărint, and M. Santangelo, "Pleistocene landslides in the Moldavian Plateau, Eastern Romania”, Georeview, vol. 
[4] M. Niculiță. and M.C. Mărgărint, "Landslides and fortified settlements as valuable geoheritage sites in the Moldavian Plateau, NorthEastern Romania, Geoheritage (submitted).

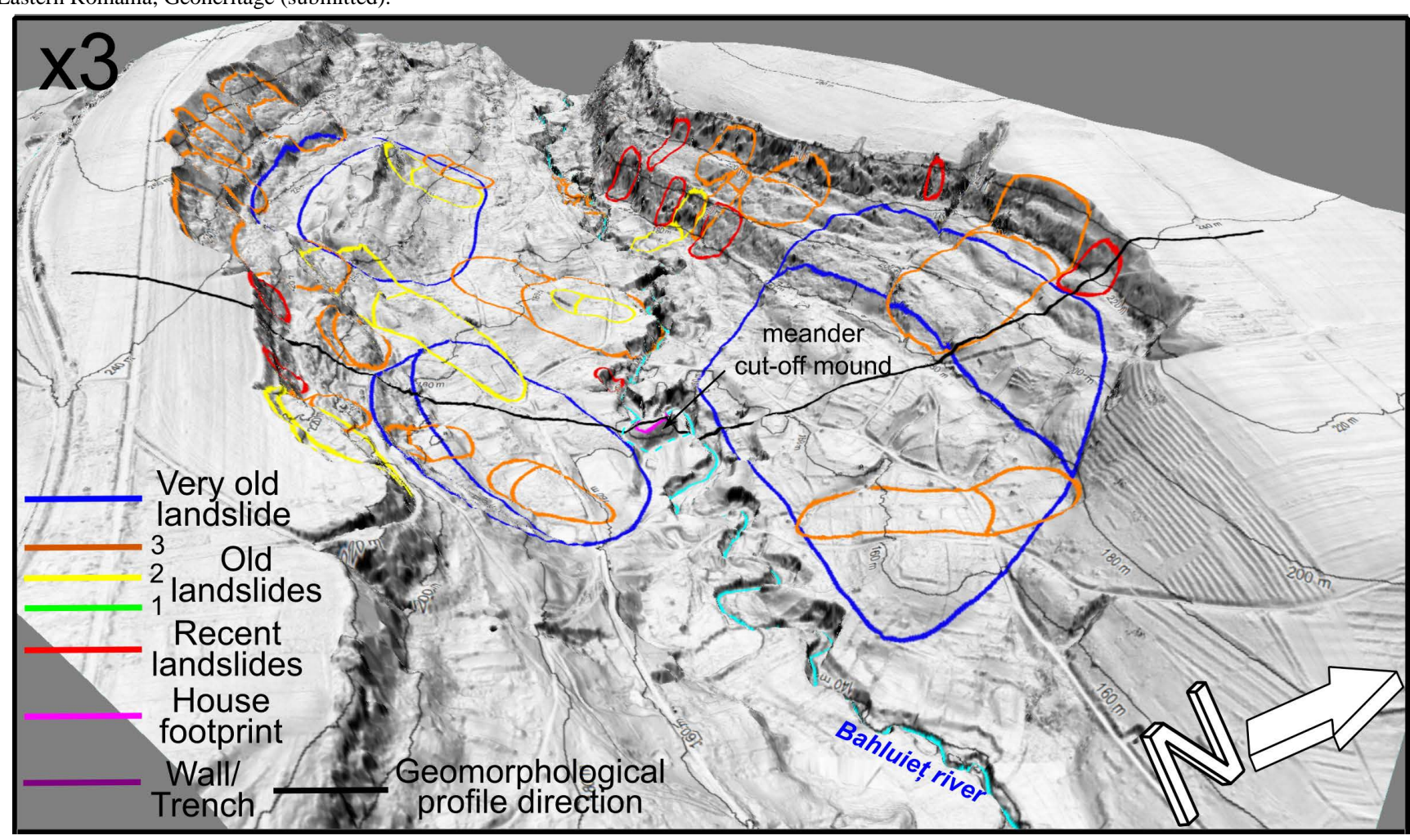

Fig. 1. 3D view of the Costeşti geoheritage site [3]: LiDAR shaded image and the landslide inventory from [1].

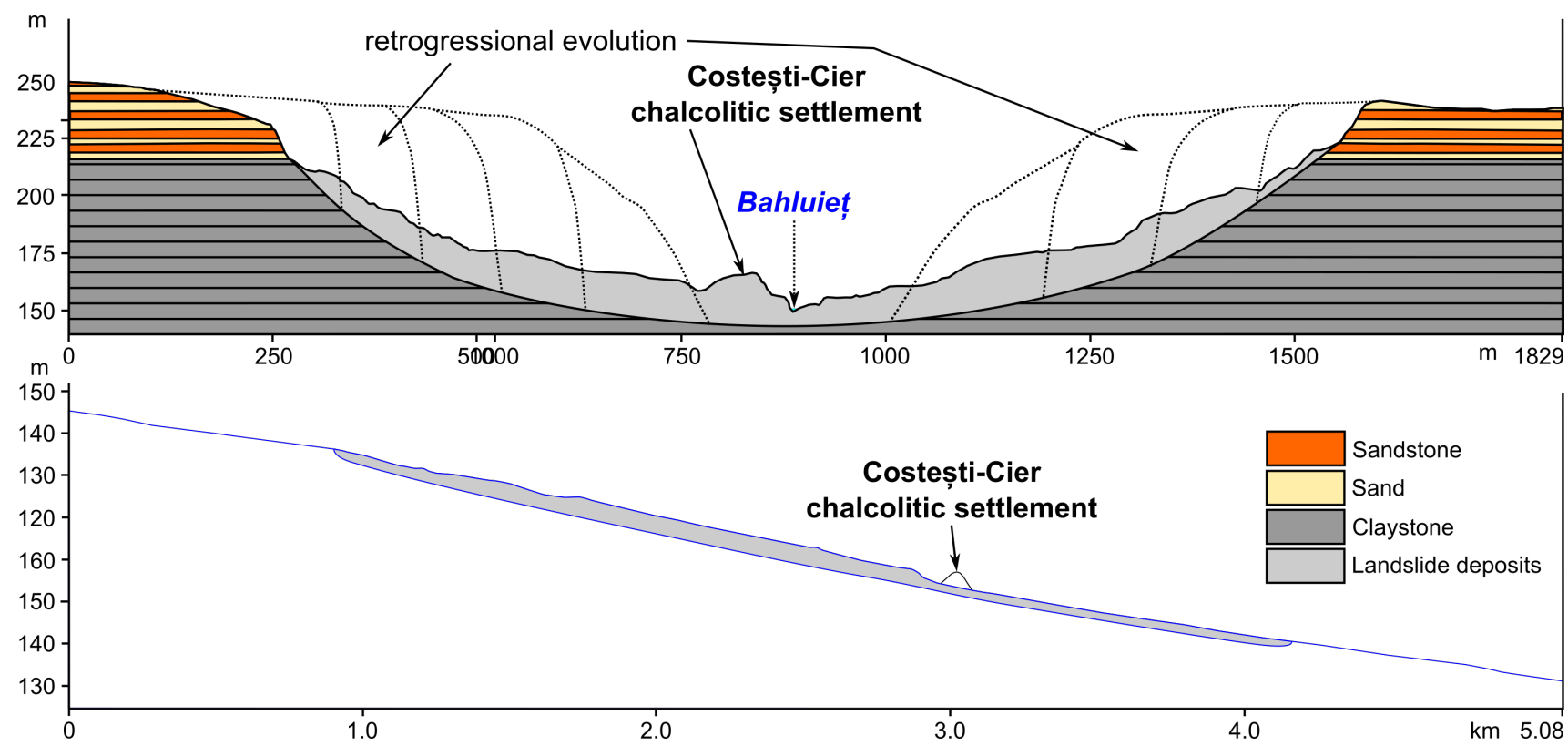

Fig. 2. Geomorphological interpretation of the Costeşti geoheritage site retrogressive mass movement model [2]. 


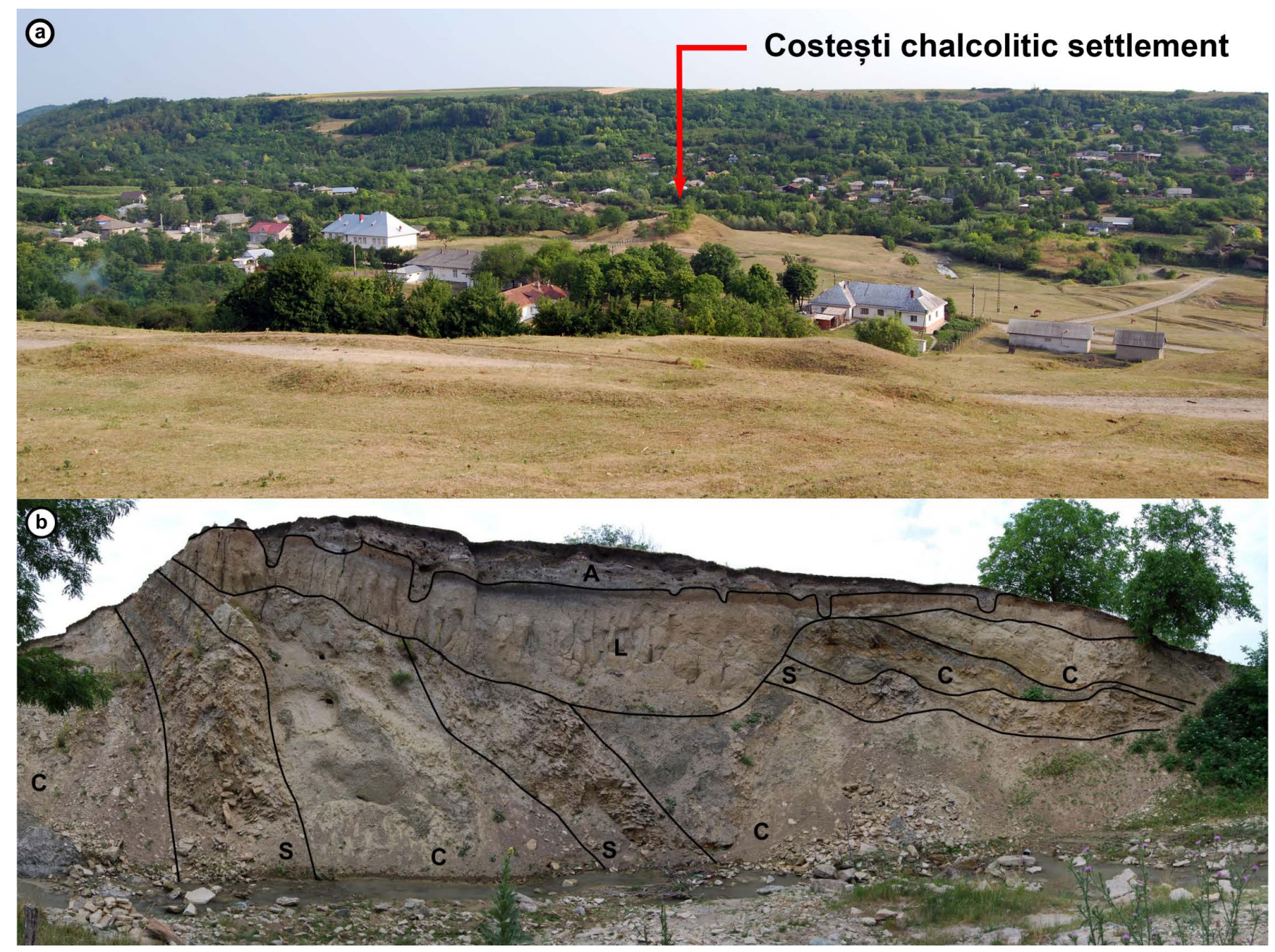

Fig. 3. Costeşti geoheritage site perspective view (a) and stratigraphic section along Bahluieţ bank [1]: A - archaeological deposit, L - loamy terrace deposit, S - sandstone layer, C - clay layer.

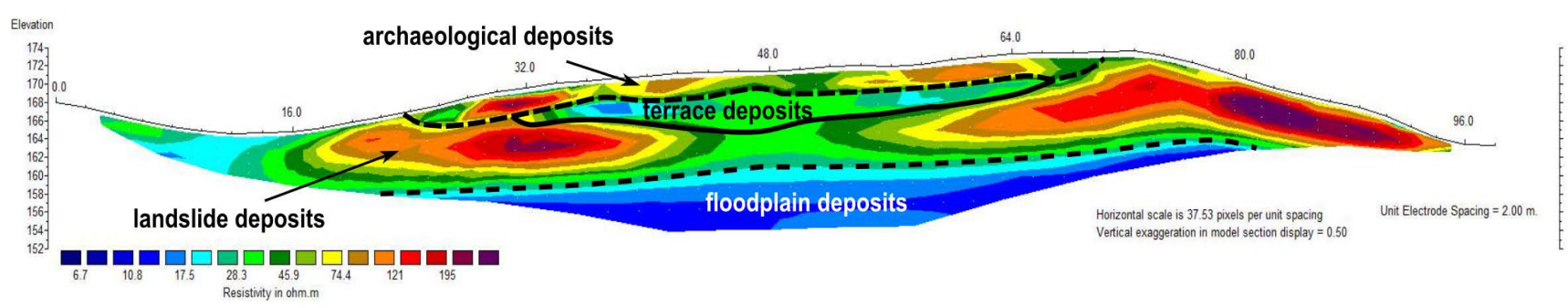

Fig. 4. Costeşti geoheritage site stratigraphy interpreted from 2D ERT. 


\section{Relict landslides, gullies and geoheritage sites - Băiceni village}

\author{
Mihai Niculiță, Mihai Ciprian Mărgărint \\ Department of Geography, Faculty of Geography and \\ Geology \\ Alexandru Ioan Cuza University of Iaşi \\ Iaşi, Romania \\ mihai.niculita@uaic.ro,margarint.ciprian@yahoo.com
}

\author{
Ionuț Cristea \\ Department of Geography \\ Faculty of Geography and History \\ Ştefan cel Mare University of Suceava \\ icristea@atlas.usv.ro
}

\section{BĂICENI GEOHERITAEGE SITE}

Cucuteni - Cetăţuia site is located at the edge of the Laiu plateau, on a promontory cut by a gully, and is bounded on north, east and south sides by deep-seated landslide scarps [1]. The main inhabitation of the settlement is attributed to Cucuteni A. This settlement is related to the Băiceni Dâmbul Morii settlement, located downstream, at the base of the hillslope, on the relict landslide deposits, between Recea and Morii rivers (Fig. 1). The site was populated in the Cucuteni $\mathrm{A}$ and $\mathrm{AB}$ phases. The complex landslides that affect the north, west and south hillslopes are retrogressive landslides which generated the slide of the sandstone layer over the underlying claystones and sands (Fig. 2).

\section{BĂICENI LANDSLIDE}

The complex landslide from Băiceni village is a relict landslide with a Lower Holocene or Upper Pleistocene age [2]. The genesis of the landslide is related to the retrogressive model of slope evolution [Fig. 2] identified by $[1,2,3]$, and used by the chalcolithic populations to establish their settlements [1].

The landslide body is covered by layers of buried paleosoils (Fig. 3 a, b) which show intense hillslope evolution and argue the old age of the initial movement.

The stratigraphy of the landslide toe, which cover the floodplain deposits of the Băiceni valley, was interpreted using a 2D ERT scan (Fig. 4). [4].

The Băiceni landslide was argued as a geoheritage site by

\section{MORII GULLY}

The Băiceni landslide is incised by two streams, which evolved (Fig. 1, 2) through regressive erosion. In the last 100 years their channel heads evolved as gullies, the Morii gully showing continuous activity from the ' 70 (Fig. 5, 6) [5].

\section{ACKNOWLEDGMENT}

We are grateful to Prut-Bârlad Water Administration who provided us with the LIDAR data. We have used the computational facilities given by the infrastructure provided through the POSCCE-O 2.2.1, SMIS-CSNR 13984-901, No. 257/28.09.2010 Project, CERNESIM (L4).

\section{REFERENCES}

[1] M. Niculiță., M.C. Mărgărint, and M. Santangelo, "Archaeological evidence for Holocene landslide activity in the Eastern Carpathian lowland”, Quaternary International, vol. 415, pp. 175-189, 2016.

[2] M. Niculiță., M.C. Mărgărint, and M. Santangelo, "Pleistocene landslides in the Moldavian Plateau, Eastern Romania", Georeview, vol. 26, $\quad$ no. 2 , $\quad$ pp. 2016. http://dx.doi.org/10.4316/GEOREVIEW.2016.0.0.341

[3] M.C. Mărgărint and M. Niculiță, "Landslide type and pattern in Moldavian Plateau, NE Romania", in Landform Dynamics and Evolution in Romania, M. Rădoane and A. Vespremeanu-Stroe, Eds. Springer, 2017, pp. 271-304. doi:10.1007/978-3-319-32589-7_12

[4] M. Niculiță. and M.C. Mărgărint, "Landslides and fortified settlements as valuable geoheritage sites in the Moldavian Plateau, NorthEastern Romania, Geoheritage (submitted).

[5] Gh. Romanescu, and I.C. Nicu, "Risk maps for gully erosion processes affecting archaeological sites in Moldavia, Romania", Zeitschrift für Geomorphologie, vol. 58, no. 4, pp. 509-523, 2014. 


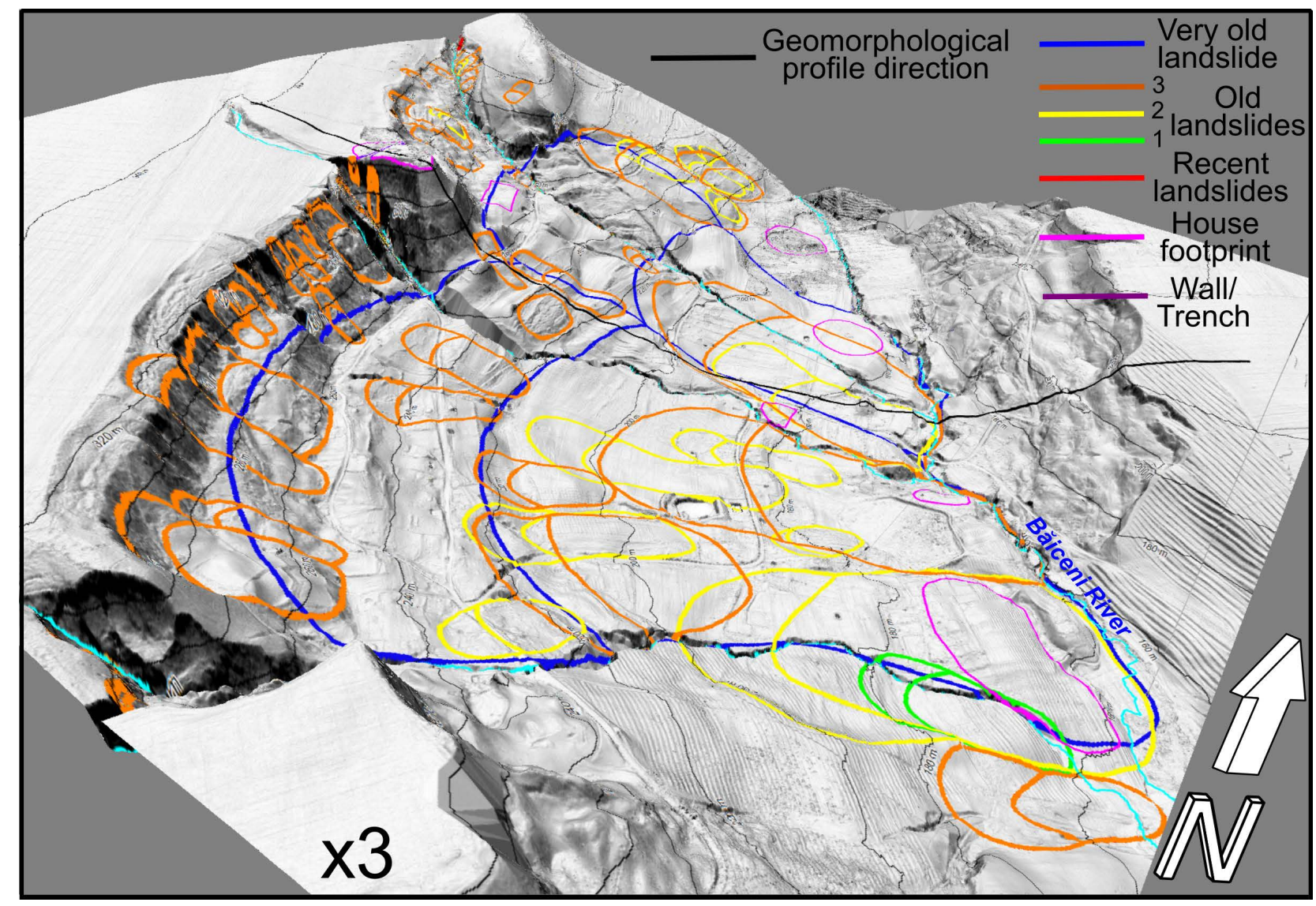

Fig. 1. 3D view of the Băiceni geoheritage site [3]: LiDAR shaded image and the landslide inventory from [1]
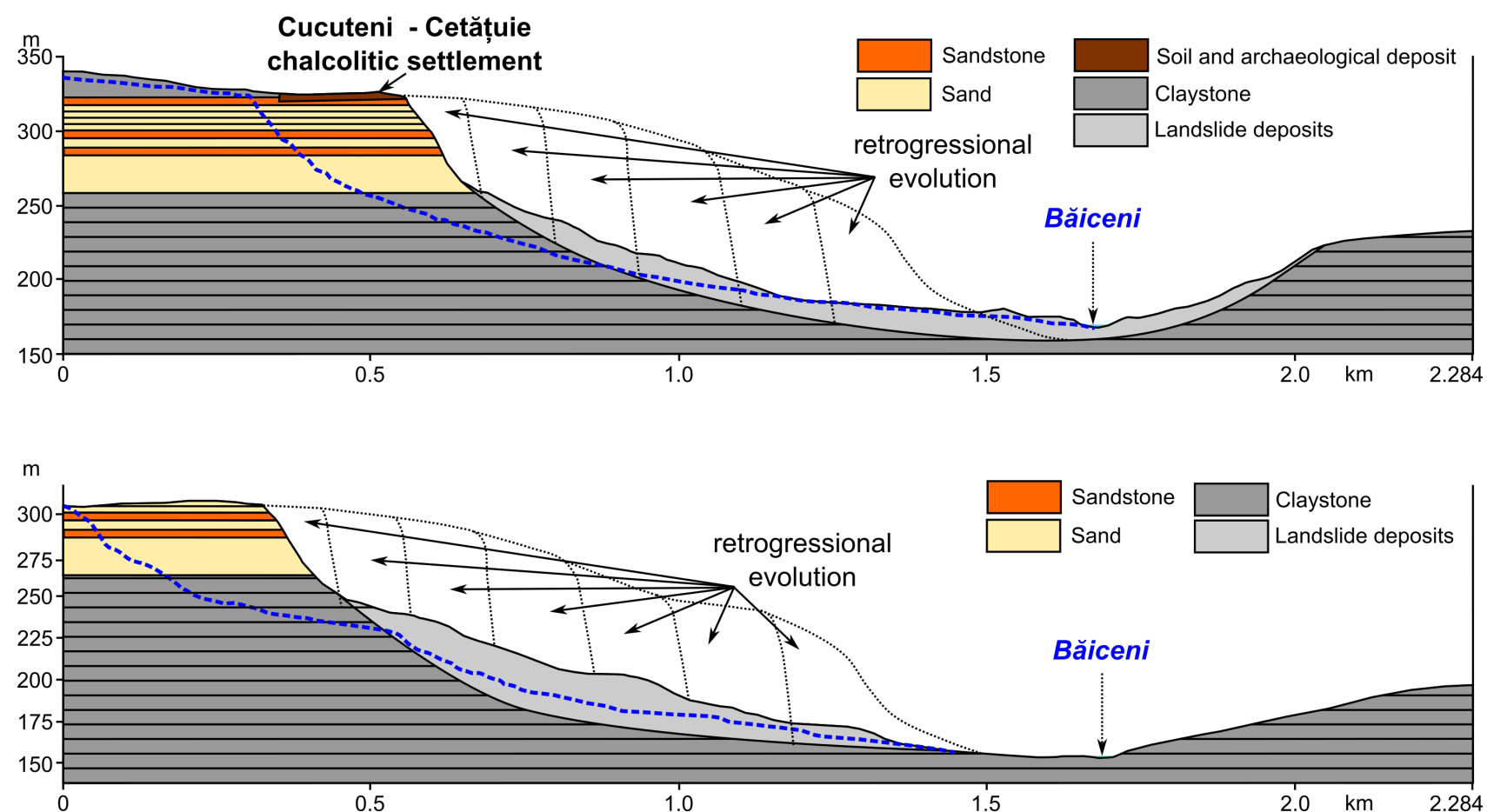

Fig. 2. Geomorphological interpretation of the Băiceni geoheritage site retrogressive mass movement model [2]. 

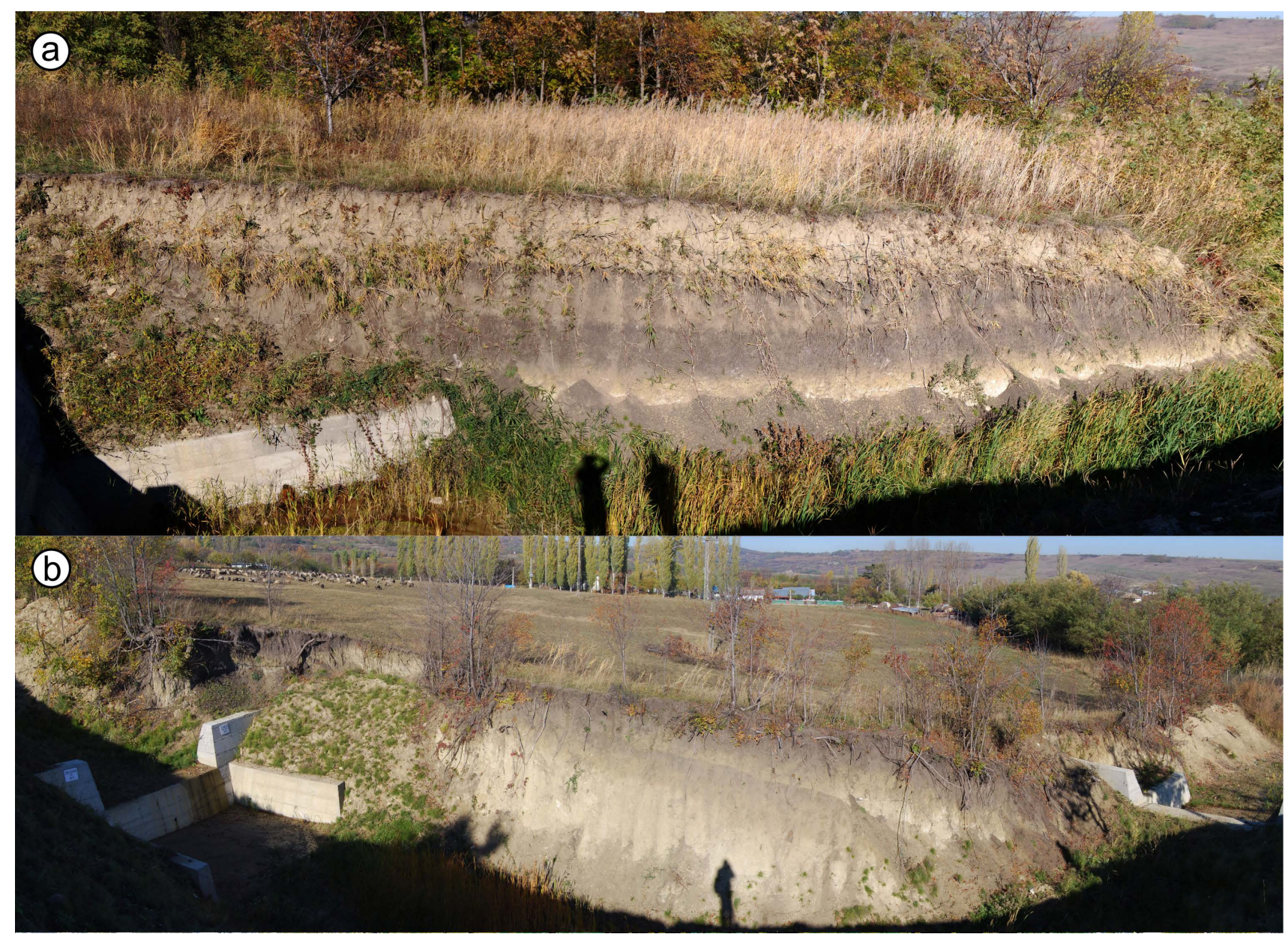

Fig. 3. Stratigraphy of the Băiceni landslide body cover, revealed in the Morii river bank showing buried soils (the location of the photos is shown in Fig. 1 - red a and b)

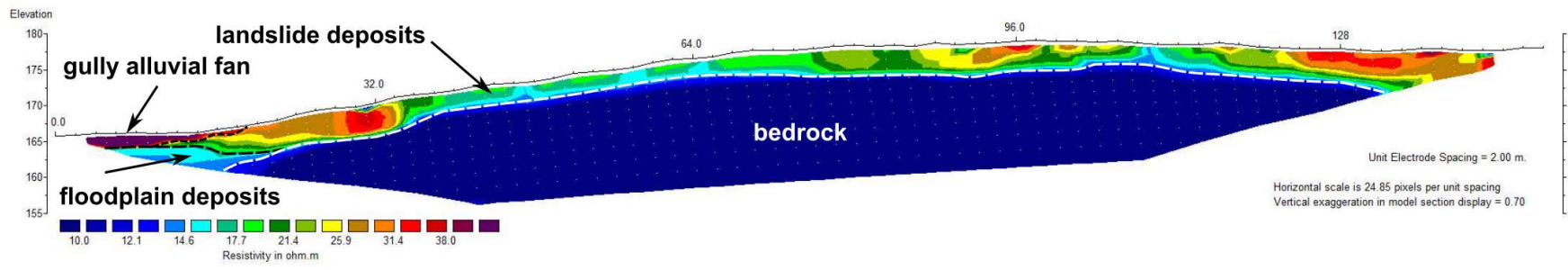

Fig. 4. Băiceni geoheritage site stratigraphy interpreted from 2D ERT. 


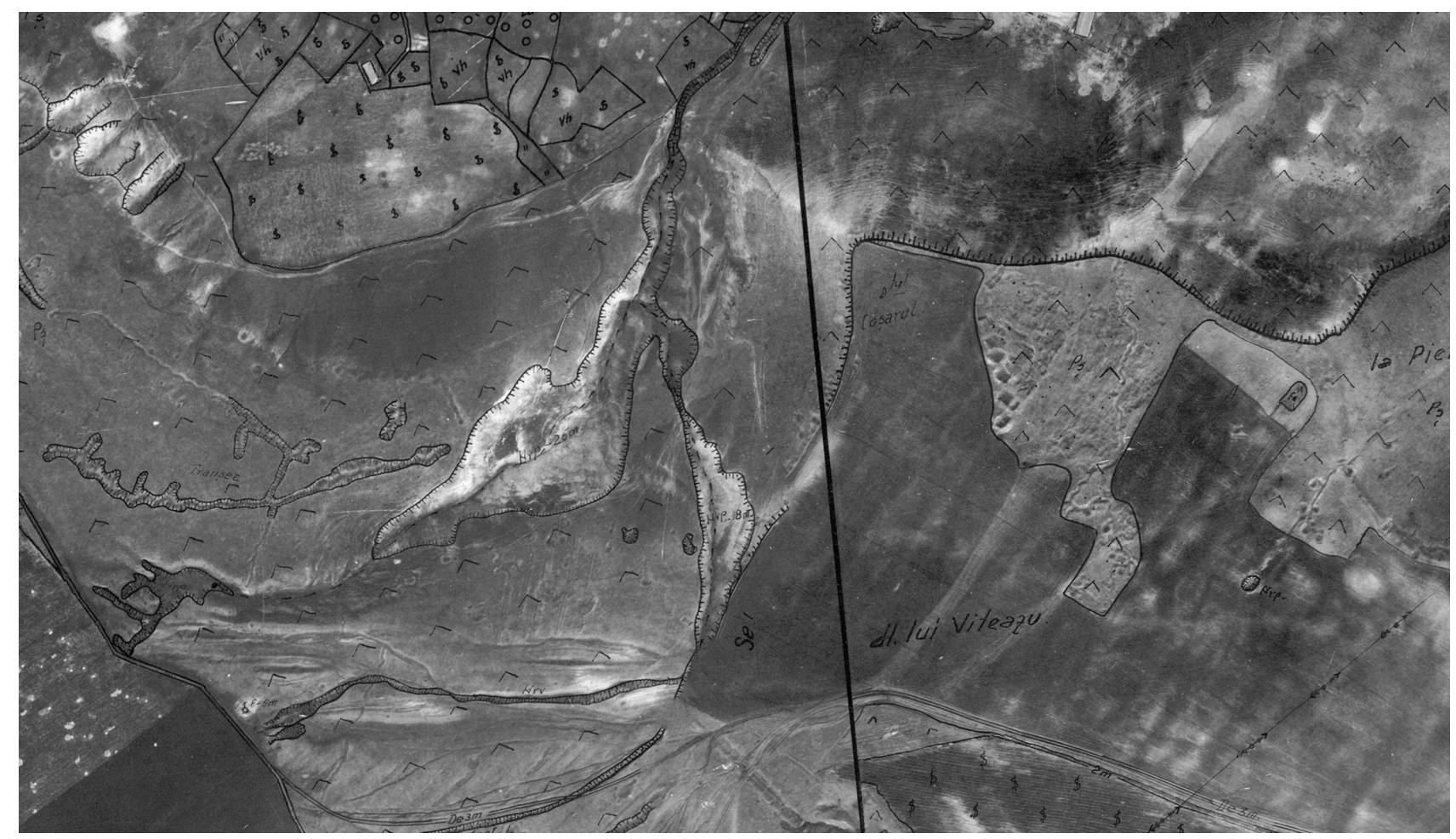

Fig. 5. Aerial image of the Morii gully (1971).

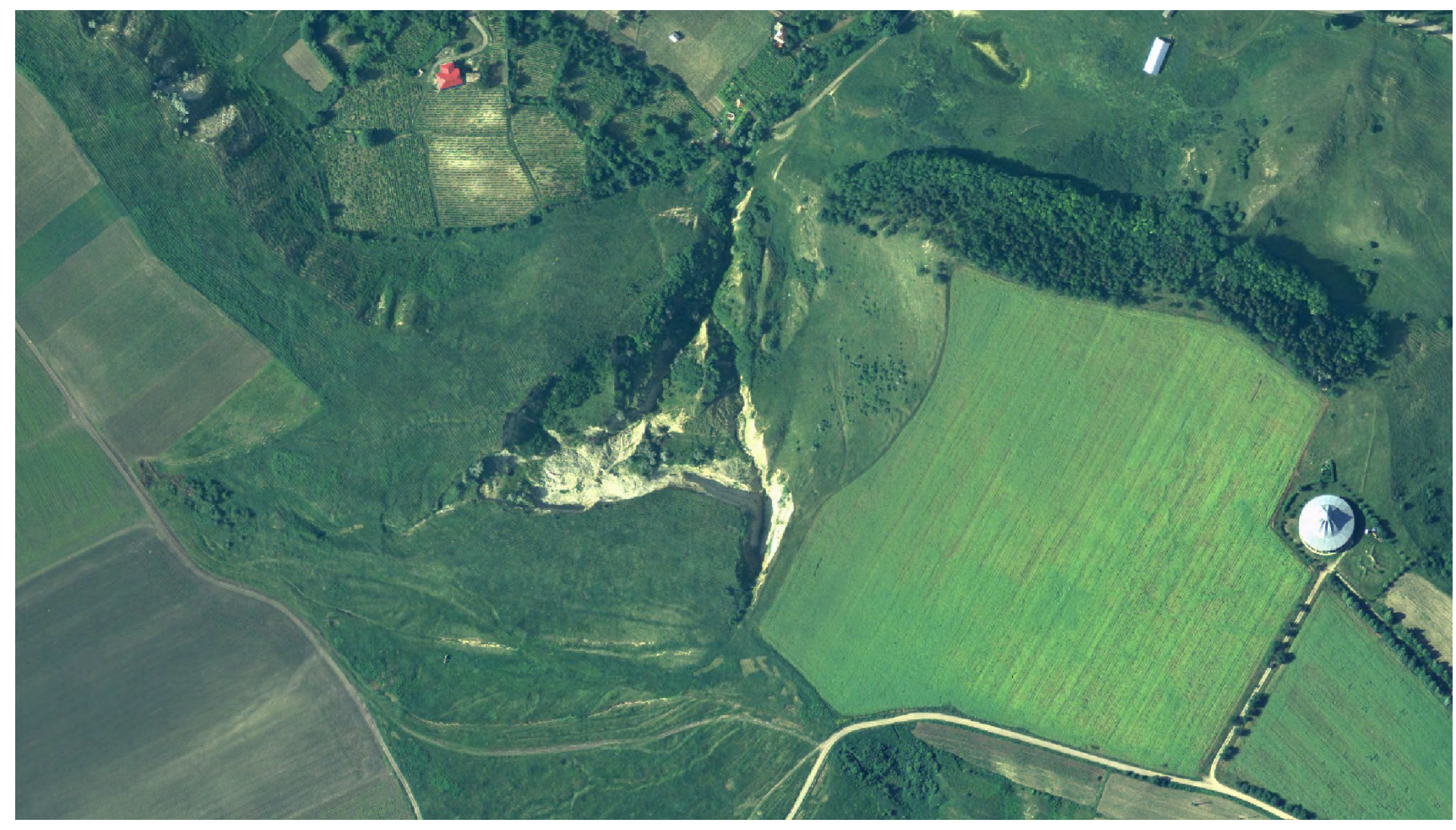

Fig. 6. Aerial image of the Morii gully (2008). 


\section{Old anthropic dams, lacustrine deposits, and gullies from Șoldănești village}

\author{
Mihai Ciprian Mărgărint, Mihai Niculiță, Silviu Doru, \\ Nicușor Necula \\ Department of Geography, Faculty of Geography and \\ Geology \\ Alexandru Ioan Cuza University of Iaşi \\ Iaşi, Romania \\ mihai.niculita@uaic.ro,margarint.ciprian@yahoo.com
}

\author{
Ionuț Cristea \\ Department of Geography \\ Faculty of Geography and History \\ Ştefan cel Mare University of Suceava \\ icristea@atlas.usv.ro
}

\section{INTRODUCTION}

A particular environmental feature of the northern part of Moldavian Plateau (NE Romania) is the large number of anthropic lakes along river courses [1, 2, 3]. Even more, due to climatic, hydrological, hydrogeological and geomorphological settings and human activities (dominated by an extensive agriculture) this characteristic was mentioned and mapped in written records and cartographic representations in many historical stages of the mentioned region humanization. The need for water supply have forced the inhabitants to build dams of various sizes along the entire river network. Over the time, many dams were abandoned, while others have been relocated with an impressive dynamic at historical time scale.

Due to their filling with sediments, many of them were abandoned during the time. Nowadays they represent a very specific anthropic fingerprint along almost every fluvial valley in this region. Recently LIDAR shading imagery allow us many possibilities to map every landforms associated with these old lakes: abandoned dams, lacustrine sediments, gullies, lacustrine terraces, alluvial fans etc.

For this field trip we selected a small hydrographic basin (Rogojeni), located in the center of Jijia catchment, in Şoldăneşti village, Botoşani County, where seven reservoirs (one active in the present and six abandoned) are present.

\section{II. ŞOLDĂNEŞTI RESERVOIRS}

Until nowadays, the spatial distribution of these historical generations of lakes was available only for certain periods (the case of historical maps) being characterized by numerous localization uncertainties and incompleteness. Analyzing recent high resolution LiDAR DEM images, we have performed an accurate inventory of abandoned dams. Using generating contour function of Global Mapper v.15.0 package, we have reconstructed an approximately spatial extension of corresponding lakes. Some of them have been recognized on old maps (topographic map form 1894, 1940, 1960, 1984), while many others have been identified and mapped for the first time in this work. Alongside this new cartographic representations and the possibilities to assess the dynamic this environmental factor, this historical inventory of old dams represent a useful database of lacustrine deposits of the studied region.

The reconstruction of the anthropic lakes network has many geoscientific relevance, concerning:

- paleoenvironmental reconstructions, by studying lacustrine sediments with multiproxy various analyses (particle size, pollen, phytolith, magnetic susceptibility, geochemistry, organic matter, and lead-210 and radiocarbon dating) available nowadays;

- anthropocene (recent) evolution and assessment of human activities on the environment, like erosion rate, agricultural practices, crop structure, related with representative hydro-meteorological past events.

\section{III. ŞOLDĂNEŞTI RESERVOIRS BOTTOM GULLIES}

The Northeastern Romania lowland is well known for its reservoir construction history and sedimentation all over the last 500 years. These reservoirs were in general small (under 1 million $\mathrm{m}^{3}$ ), shallow (4-5 $\mathrm{m}$ in depth, but with water levels of up to $3 \mathrm{~m}$ ) and frequently dry during the summer or winter. This anthropic intervention created a concentration of flow at high water discharges in the spillway area, which allowed the evolution of gullies on the flat lacustrine bottom.

From the six abandoned reservoirs located in the upper Rogojeni catchment, two present bottom reservoir gullies. These gullies are presented in Figs 1, 2 and 3. In Fig. 4 there are illustrated cross-section trough the reservoir bottom and through gully channels, while in Fig. 5 ERT scan are shown to illustrate the depth of reservoir sediment which are shown in Fig. 6.

\section{CONCLUSIONS}

The identification and mapping with a high spatial precision of the abandoned dams constitute important element in paleogeographic reconstruction, at least for the last centuries, due to sedimentary archives behind these dams. Future research of these valuable archive can improve the knowledge of environmental evolution and anthropic impact at regional scale. 
New technologies like ERT scanning complete the classical ones in validation of the topographical reconstruction of the landforms using high resolution DEM's.

Many other applications of the LIDAR DEMs will be used for assessing and mapping other anthropic landforms which were difficult to map until the present.

The erosional presented patterns are related to the potential of the reservoir bottoms to become erosional hot spots, showing the potential of the acceleration of erosional processes, with theirs negative consequences.

\section{ACKNOWLEDGMENT}

We are grateful to Prut-Bârlad Water Administration who provided us with the LIDAR data. We have used the computational facilities given by the infrastructure provided
$26.92^{\circ} \mathrm{E}$ through the POSCCE-O 2.2.1, SMIS-CSNR 13984-901, No. 257/28.09.2010 Project, CERNESIM (L4).

\section{REFERENCES}

[1] M.C. Mărgărint and M. Niculiță, "Using high resolution LIDAR DEM to reconstruct historical network of lakes and wetlands in the Northern part of the Moldavian Plateau, NE Romania”, Georeview, vol. 26, no. 2, pp. 59, 2016. http://dx.doi.org/10.4316/GEOREVIEW.2016.0.0.336

[2] M. Niculiță, M.C. Mărgărint, and P. Tarolli, "Historical reservoir construction: potential hotspot of anthropogenic induced sediments in lowland Northeastern Romania”, Geophysical Research Abstracts, vol. 19, EGU2017-11922-1, 2017.

[3] M.C. Mărgărint, M. Niculiță, A. Nemeth, and I. Cristea, "Topographic and depositional signature of old anthropic lakes in northern part of the Moldavian Plateau (NE Romania)", Geophysical Research Abstracts, vol. 19, EGU2017-12206-1, 2017.

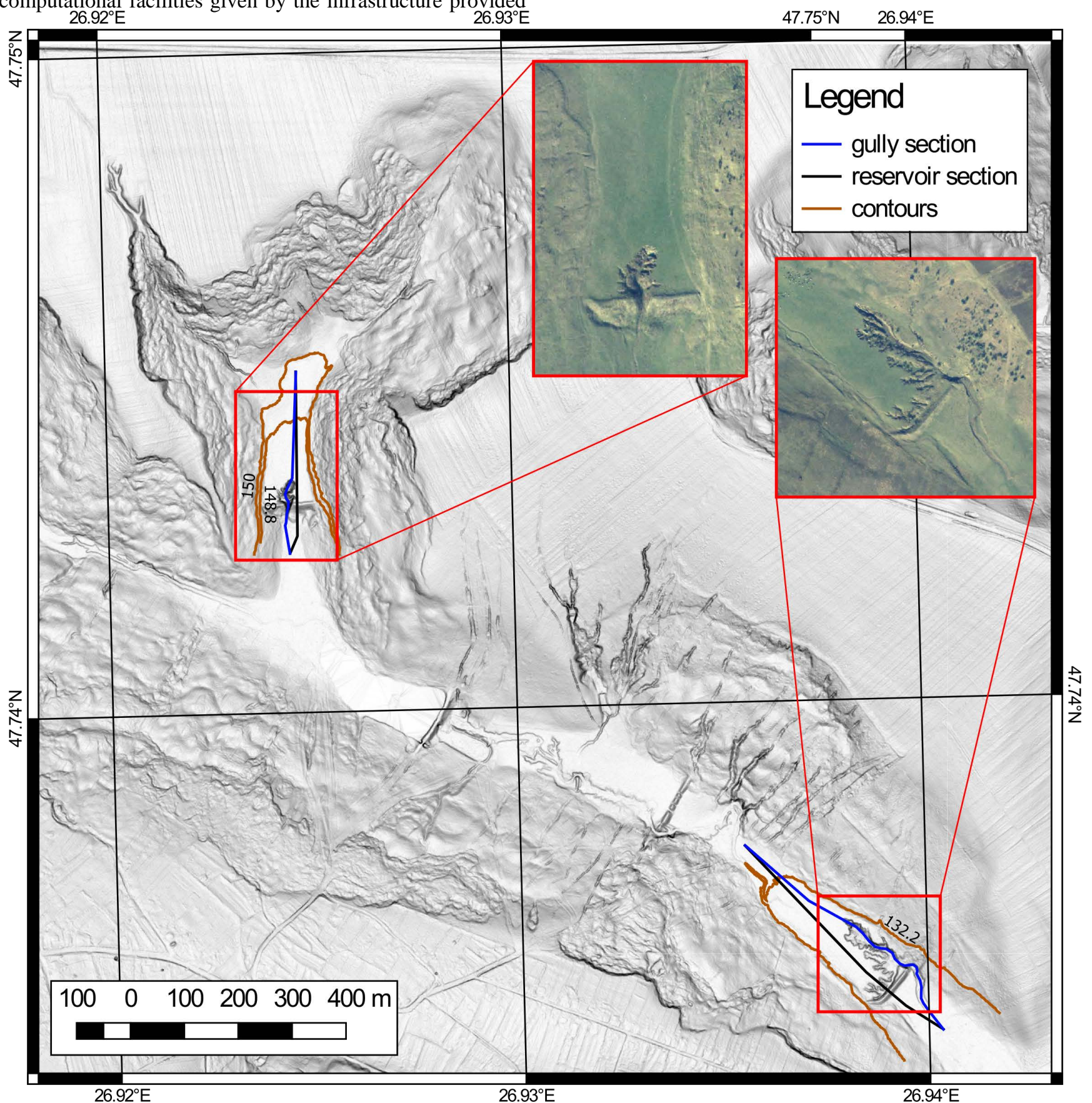

Fig. 1. Overview of the Șoldănești reservoirs, dams and gullies on LiDAR shading 


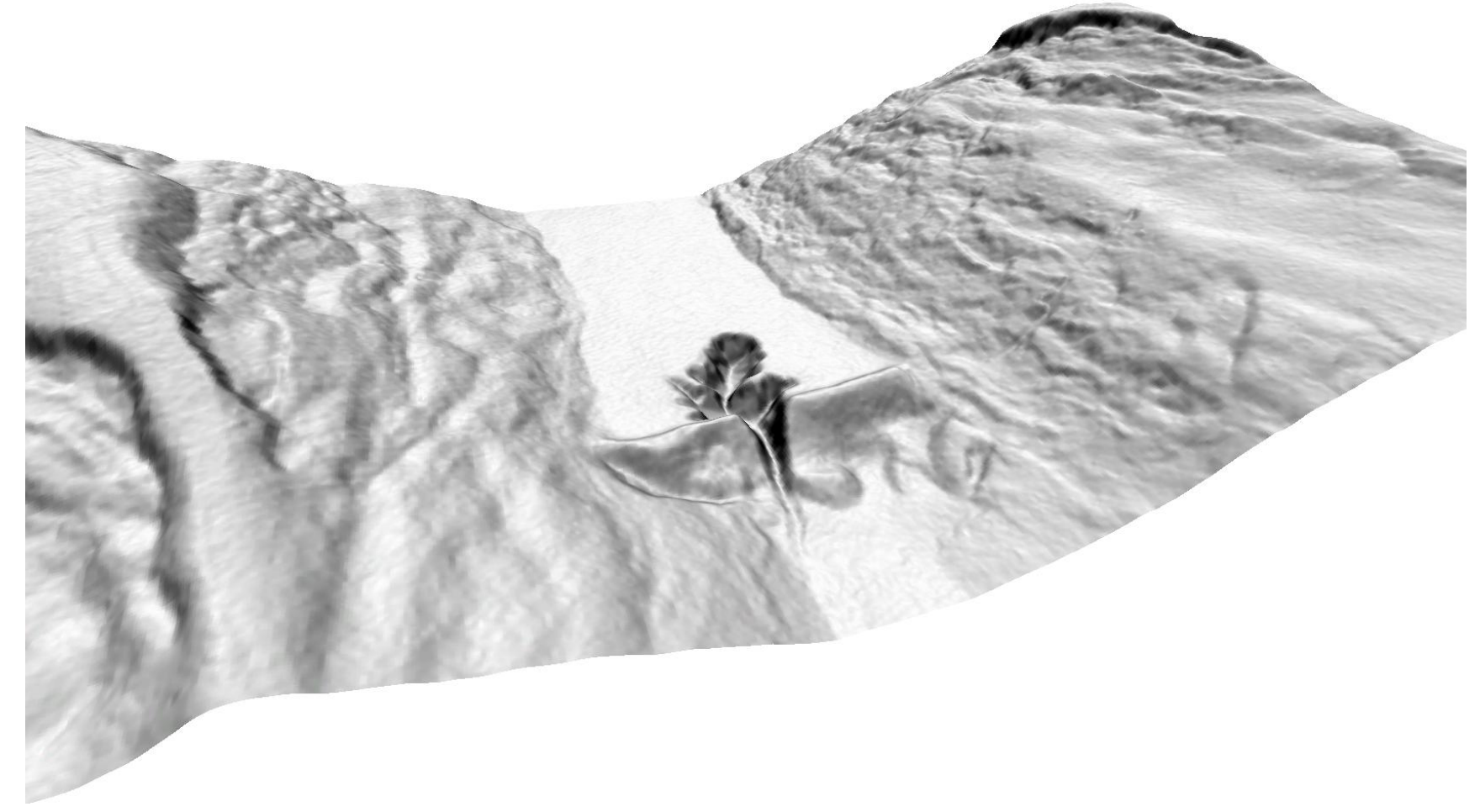

Fig. 2. 3D view of LiDAR shading for the northern gully and reservoir.

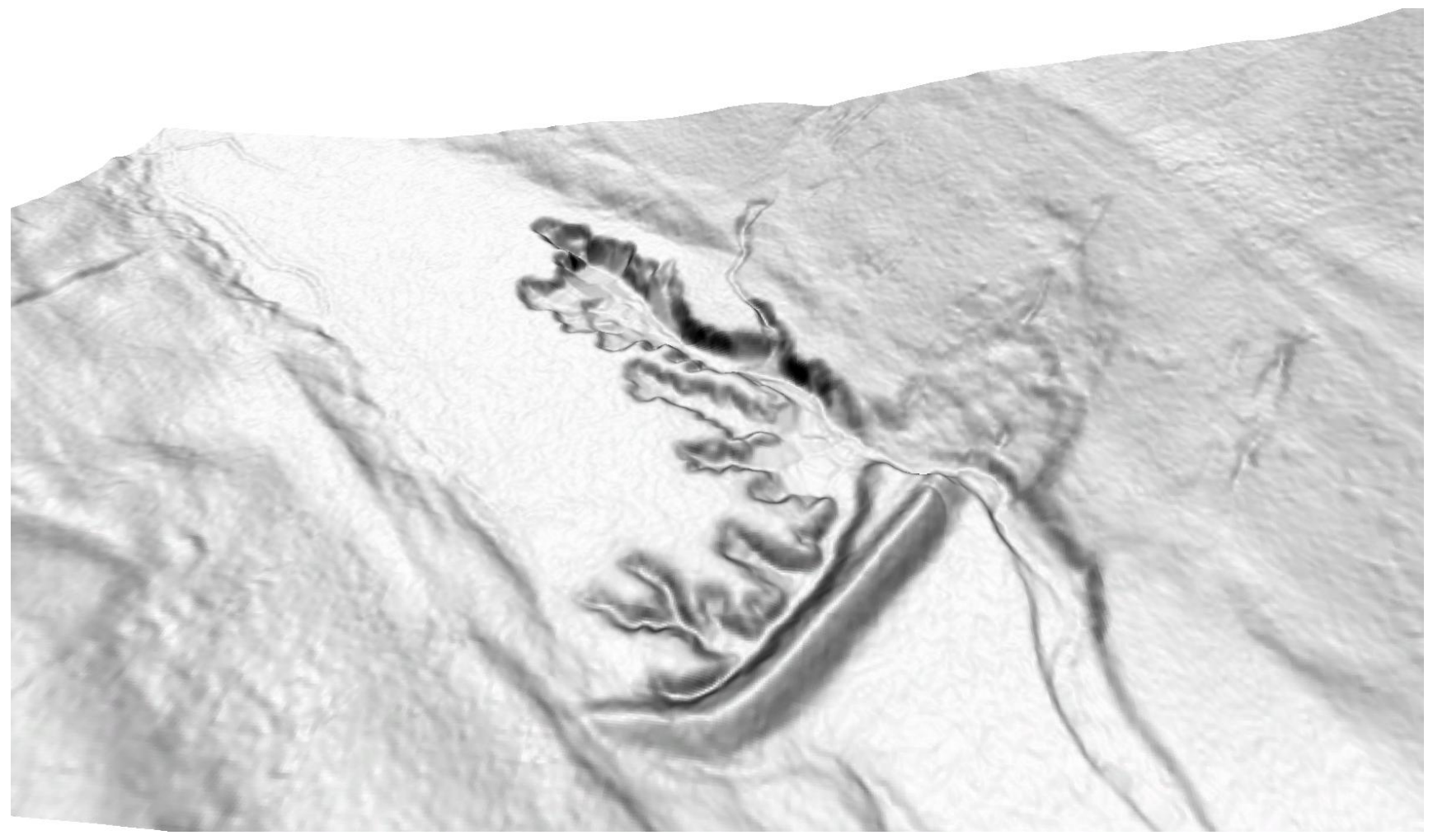

Fig. 3. 3D view of LiDAR shading for the southern gully and reservoir. 

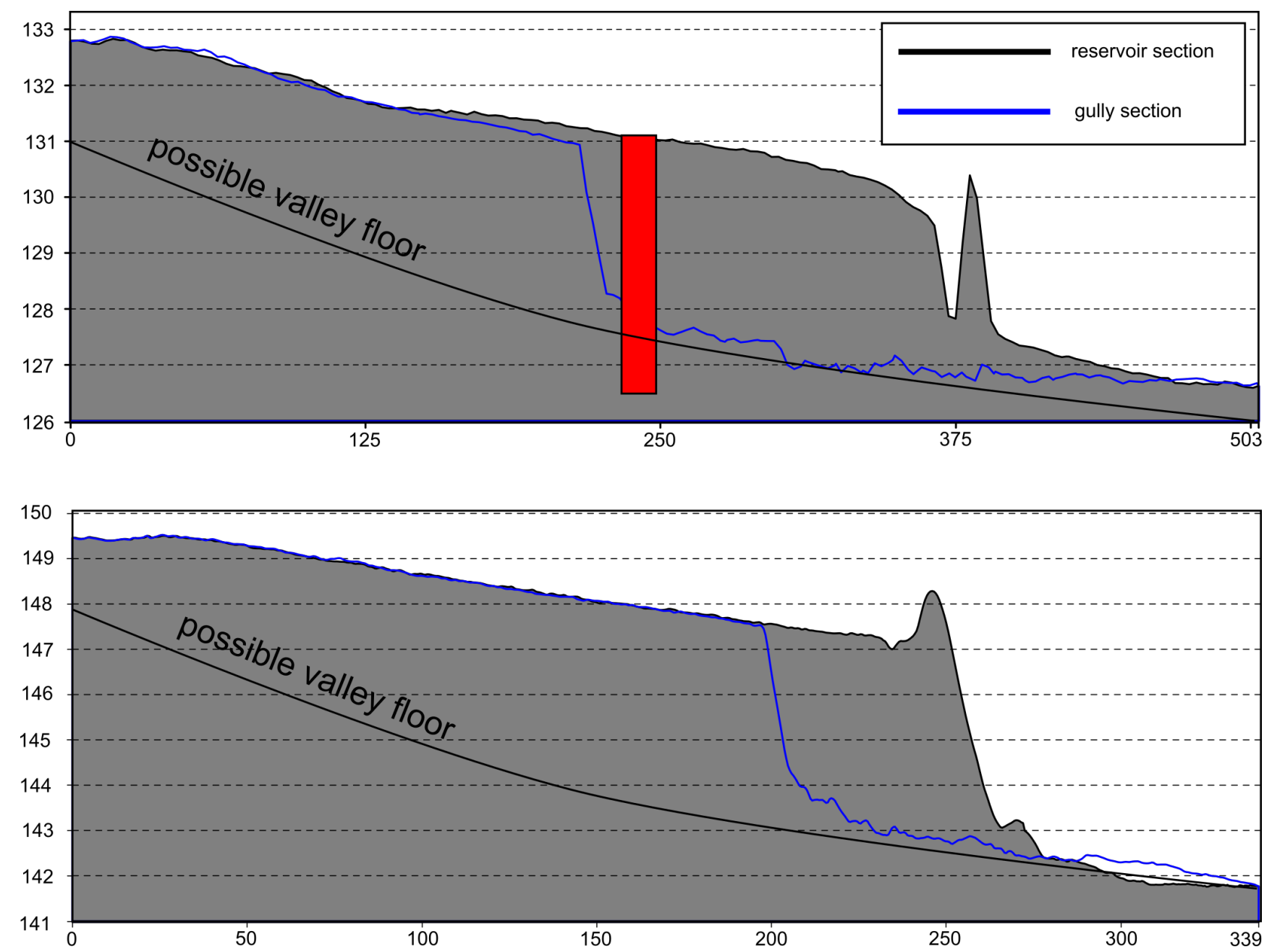

Fig. 4. Topographic section through the reservoirs (black line) and trough the bottom gullies (blue line) (upper section is for the southern gully, bottom section is for the northern gully).

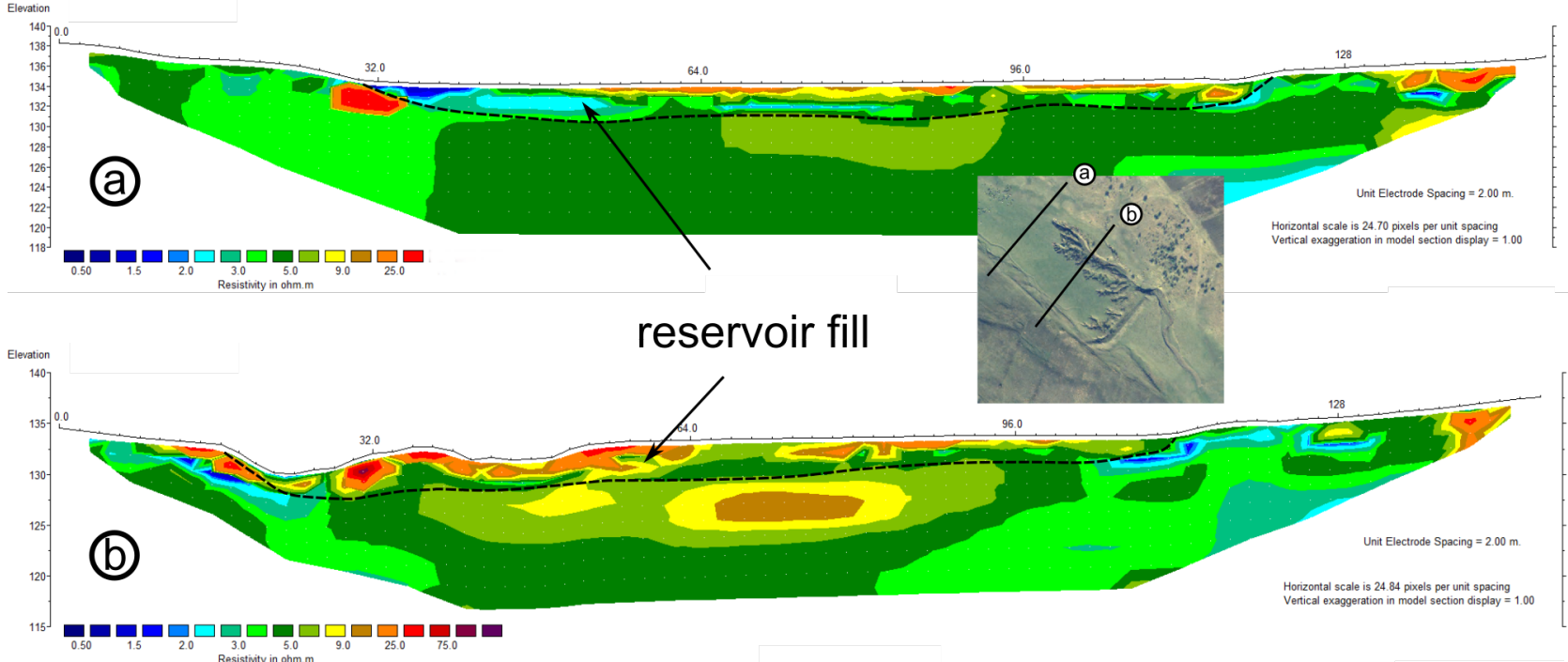

Fig. 5. Southern reservoir stratigraphy interpreted from 2D ERT scans. 


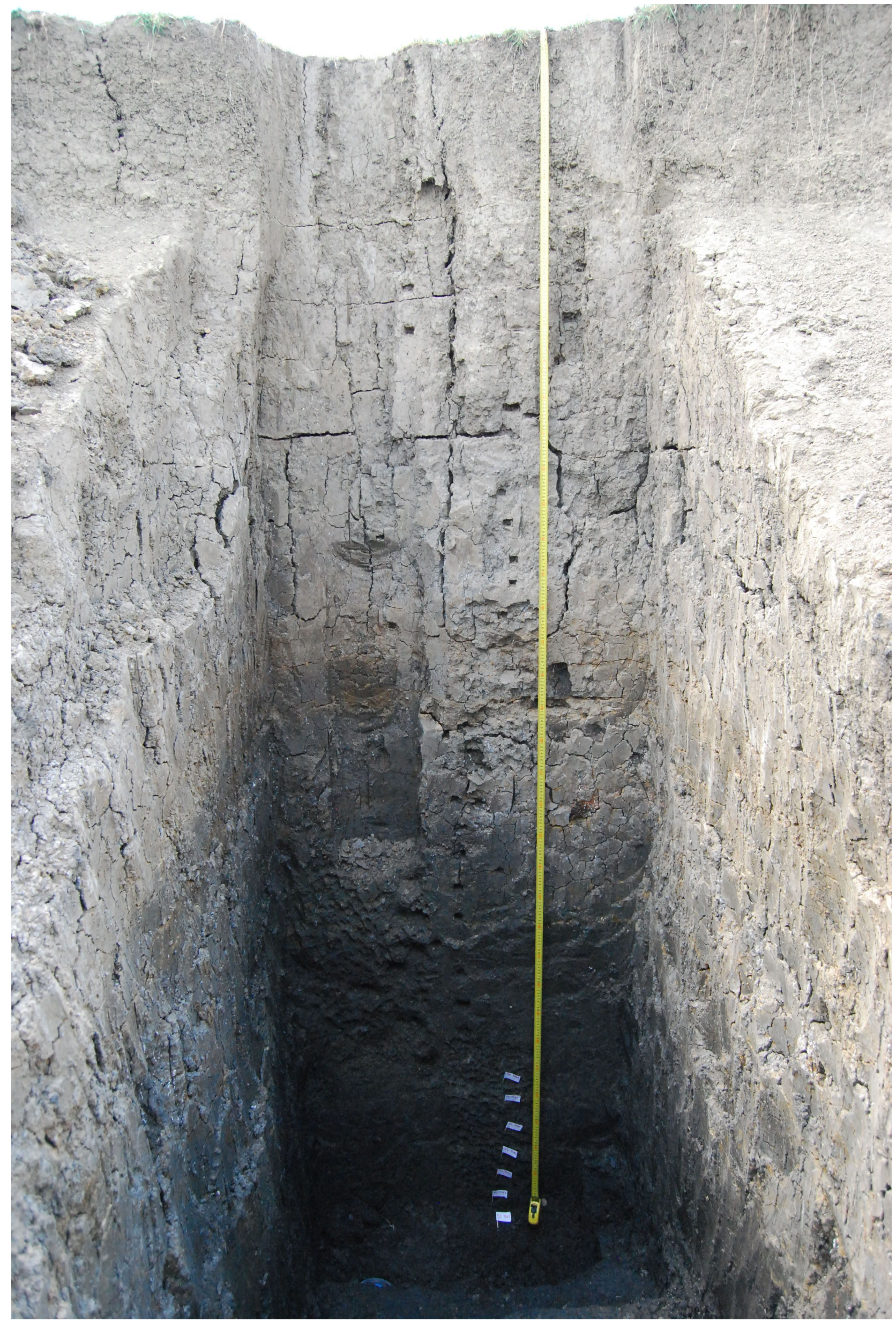

Fig. 6. Sediment column of the southern reservoir (the location and depth of the column is indicated in Fig. 4). 


\title{
Degraded agricultural terraces, landslides and gullies from Libertatea village
}

\author{
Mihai Niculiță, Mihai Ciprian Mărgărint \\ Department of Geography, Faculty of Geography and Geology \\ Alexandru Ioan Cuza University of Iaşi \\ Iaşi, Romania \\ mihai.niculita@uaic.ro,margarint.ciprian@yahoo.com
}

Terraced landscapes of Romania are the result of recent modifications of agricultural landscapes, being characterized mainly by agro-terraces (as land use) and earth terraces (as construction material) [1]. While some references of preroman (Cotofeni Culture - 3000 BP and Iron Age Dacia) and roman agricultural terraces are cited in the archaeological literature, the majority of the agricultural terraces of Romania were built during the Austro-Hungarian conquest of Transylvania in the 19th century or after the World Second War, during the communist regime (1960-1980). Nowadays the terracing is done on small areas in the same approach as during the communist regime [2].

The main purpose of the terraces was to create a flat surface were crops can be grown in good conditions, and to reduce the soil erosion, by decreasing the slope and the length of the hillslope. Water conservation was also targeted, the decrease of slope increasing the water retention in soils, on the terrace benches.

The 19th century terraces are mainly bench terraces, while the 20th century terraces are mainly broad-base terraces for hillslopes with slope under $15-20 \%$ and bench terraces for hillslopes over 15-20\%.

Degradation by the lack of maintenance and change of land use are one of the most important challenges regarding the terraced landscapes of Romania [3].

Soil erosion, landsliding and gullying will affect these lands, since the land use and the maintenance are the single measures that can reduce them (in the absence of stone walls and drainage systems).

The mapping of the terraced areas is a must in order to better assess the state of these lands and to be able to propose measures to reduce the degradation of soils and landscapes $[4,5]$.
The Chișcata upper catchment (locally known as Hârtopul Lupăriei) from the territory of Libertatea and Călărași villages is a representative area for the situation of Romanian abandoned terraced landscapes (Fig. 1), where soil erosion, gully erosion and landslides (Fig. 2, 3, 4) have a continuous dynamic.

\section{ACKNOWLEDGMENT}

We are grateful to Prut-Bârlad Water Administration who provided us with the LIDAR data. We have used the computational facilities given by the infrastructure provided through the POSCCE-O 2.2.1, SMIS-CSNR 13984-901, No. 257/28.09.2010 Project, CERNESIM (L4).

\section{REFERENCES}

[1] M. Niculiță, “Terraced landscapes of Romania”, $3^{\text {rd }}$ World Meeting on Terraced Landscapes, 6-15 October 2016, Venice-Padua.

[2] C.M. Mărgărint, M. Niculiță, and P. Tarolli, "Types and evolution stages of the agricultural terraces in the northern part of the Moldavian Plateau (NE Romania) based on their geomorphometric characteristics", $3^{\text {rd }}$ World Meeting on Terraced Landscapes, 6-15 October 2016, VenicePadua.

[3] C.M. Mărgărint, M. Santangelo, M. Niculiță, and F. Bucci, "Spatiotemporal relation between landslide occurrence and abandoned or not maintained agricultural terraces in the Moldavian Plateau, NE Romania”, Geophysical Research Abstracts, vol. 18, EGU2016-9495-1, 2016.

[4] P. Tarolli and G. Sofia, "Human topographic signatures and derived geomorphic processes across landscapes", Geomorphology, vol. 255, pp. 140-161, 2016.

[5] P. Tarolli, G. Sofia, S. Calligaro, M. Prosdocimi, F. Preti, and G. Dalla Fontana, "Vineyards in terraced landscapes: new opportunities from Lidar data”, Land Degradation and Development, vol. 26, no. 1, pp. 92102, 2015 


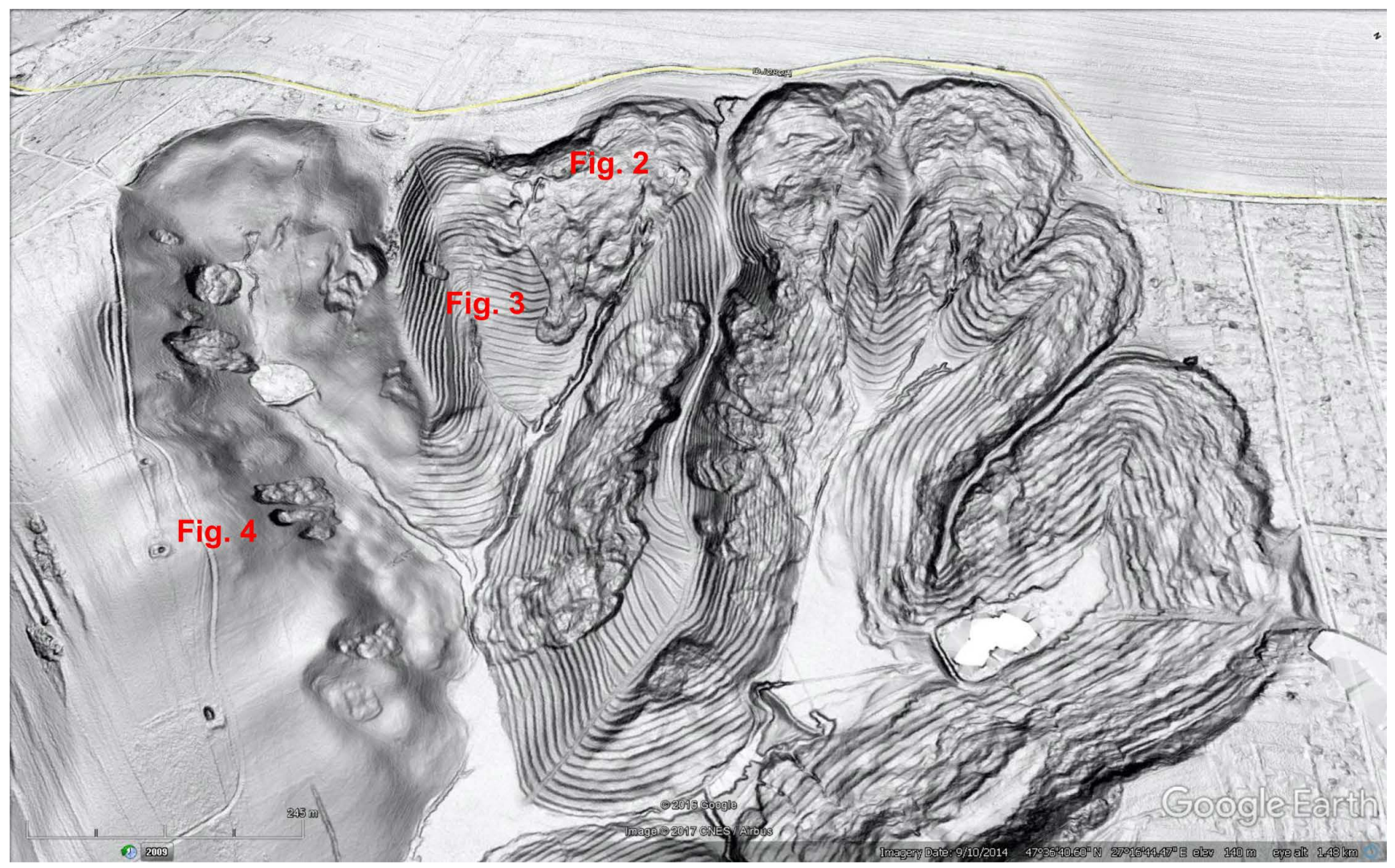

Fig. 1. The Lupăriei Hârtop from Libertatea and Călăraşi villages: shaded LiDAR view.

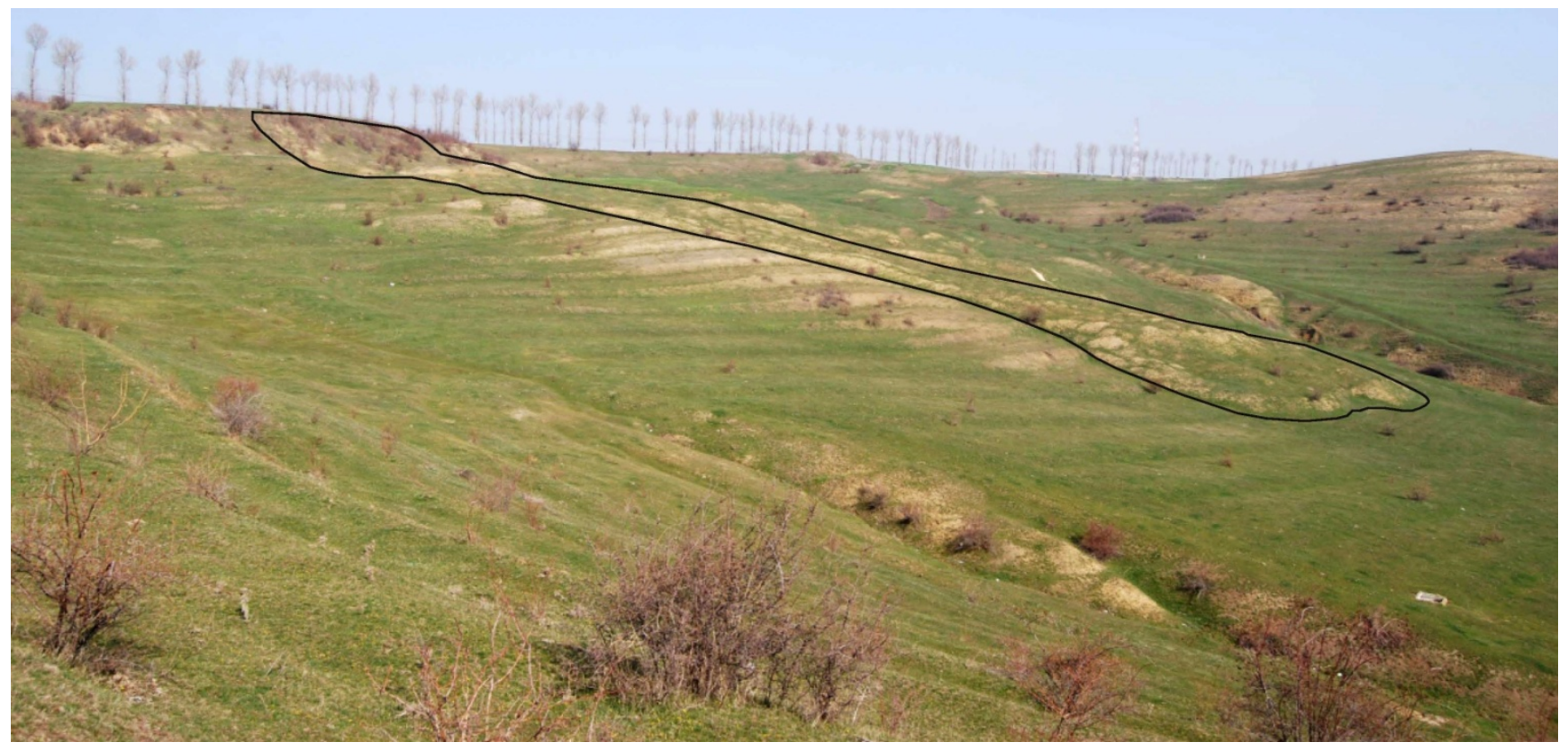

Fig. 2. A flow from the Lupăriei Hârtop. 


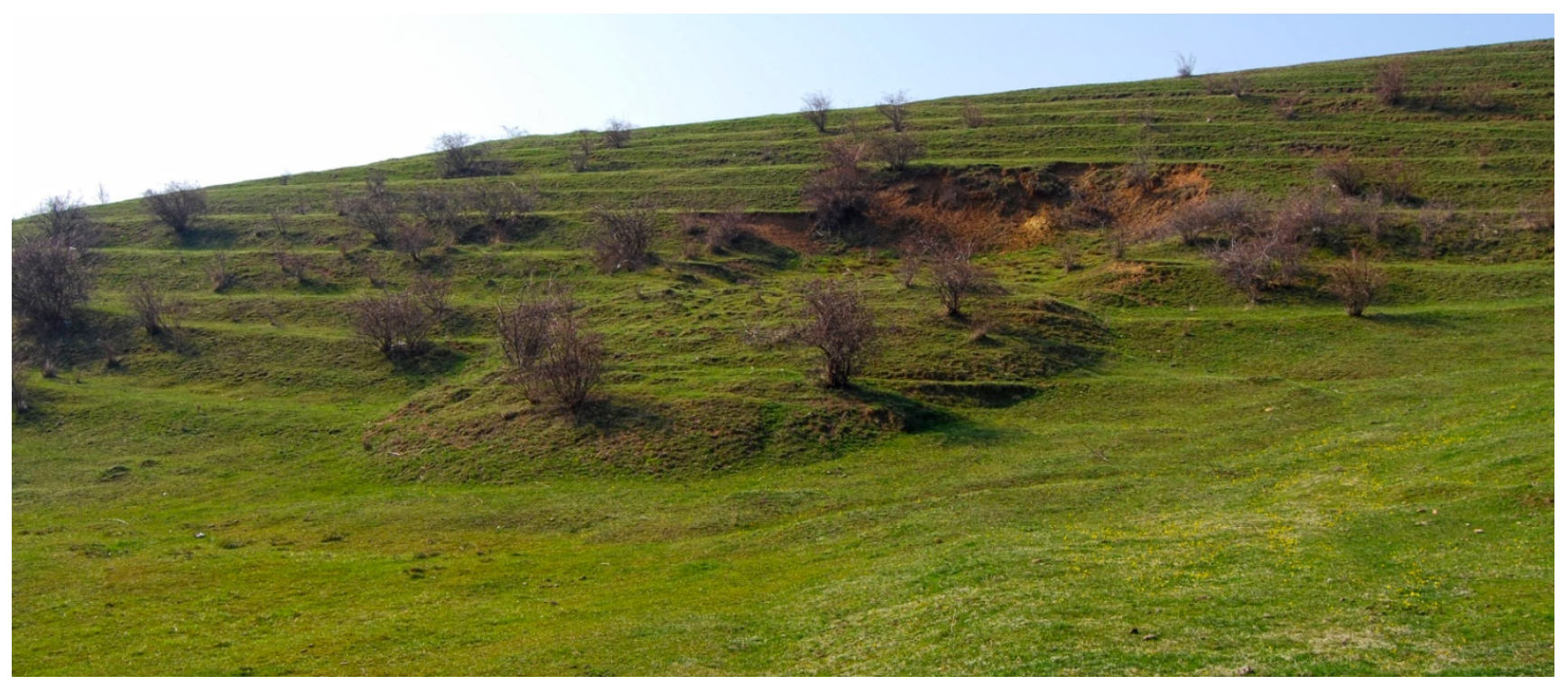

Fig. 3. A translational landslide from the Lupăriei Hârtop.

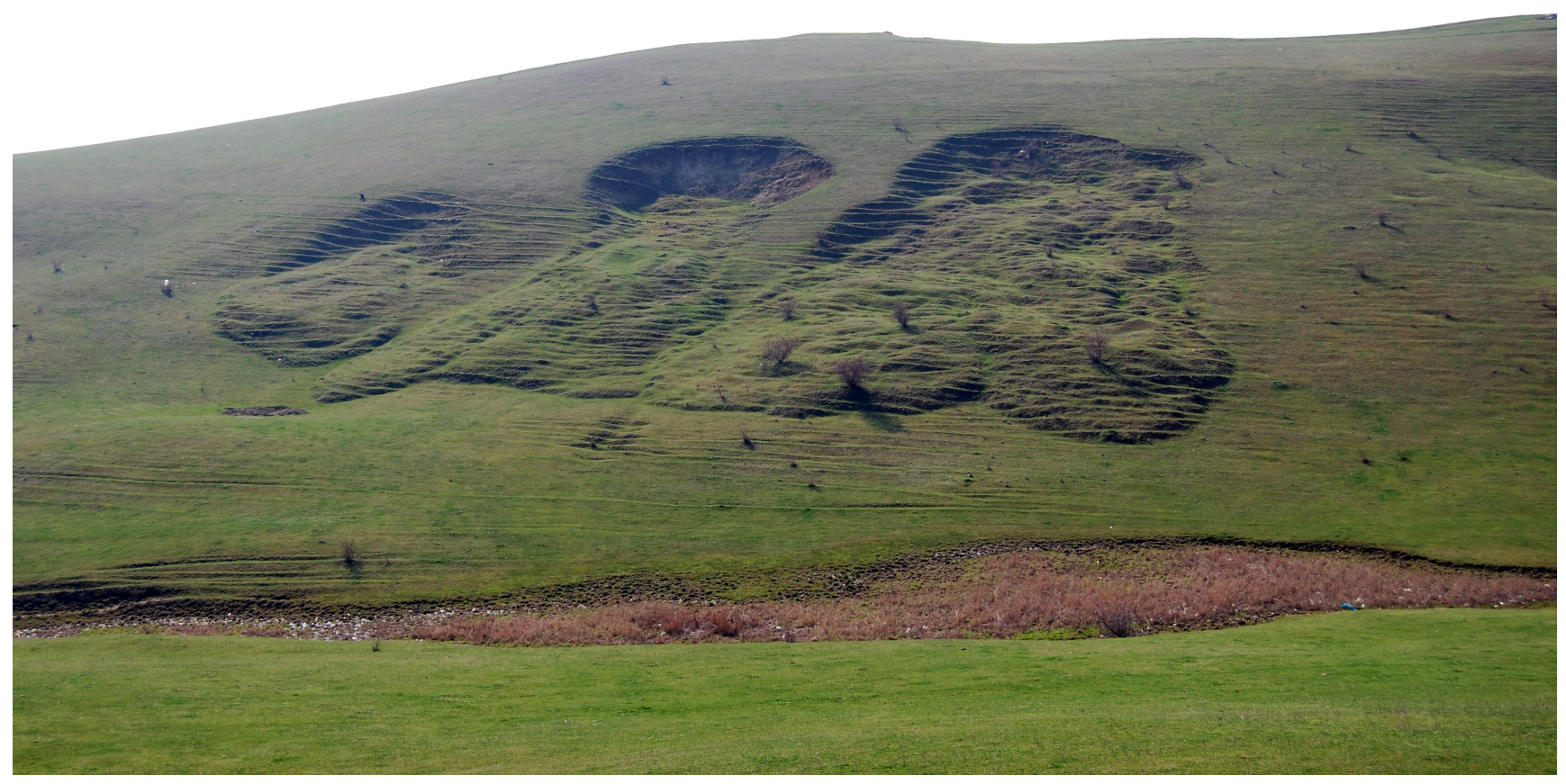

Fig. 4. Translational slides and flow-slides from the Lupăriei Hârtop. 


\title{
Berza- Santa Mare complex landslide
}

\author{
Mihai Niculiță, Mihai Ciprian Mărgărint \\ Department of Geography, Geography and Geology Faculty \\ Alexandru Ioan Cuza University of Iaşi \\ Iaşi, Romania \\ mihai.niculita@uaic.ro,margarint.ciprian@yahoo.com
}

Remarkable for the Moldavian Plateau is the large extension of landslides which cannot be attributed to a single genetic mechanism [1]. In many cases, a single type of movement is impossible to be assigned to a slope mass delimited and mapped in a polygonal manner. For these situations, [2] introduced the term of complex landslides, which can be detailed using a composite terminology [3].

This is the case of an impressive landslide located along the Prut Valley, in between Santa Mare and Berza localities, on a sector of more than $8 \mathrm{~km}$.

The different types of movements can be recognized through the abundance of a large variety of micromorphologic details of landslides (secondary scarps, lateral cracks, various roughness, micro-depressions, mounds). This morphological complexity is related to a long-term evolution. Generally, a fresh morphology is associated with the translational slides and flows and this issue emphasizes a clear differentiation between present and past processes and created landforms [4, 5]. A large part of this complex landslides, but also some event-based landslides are more wide than long, and this is due to the structural cuesta landforms. The evolution of this landslide seems to be close with a particular landform from Transylvanian Plateau, called "glimee" slides. Further detailed analyses are needed in order to better understand the mechanisms of the entire area of the landslide (more than $6 \mathrm{~km}^{2}$ ) and the recent evolution of theirs fresh parts.

This is the last our stop of the field trip, and we have chosen this point, a valuable geomorphologic lookout point, in order to think, discuss and to find future directions in the research of landforms of the Moldavian Plateau.

\section{ACKNOWLEDGMENT}

We are grateful to Prut-Bârlad Water Administration who provided us with the LIDAR data. We have used the computational facilities given by the infrastructure provided through the POSCCE-O 2.2.1, SMIS-CSNR 13984-901, No. 257/28.09.2010 Project, CERNESIM (L4).

\section{REFERENCES}

[1] M.C. Mărgărint and M. Niculiţă, "Landslide type and pattern in Moldavian Plateau, NE Romania”, in Landform Dynamics and Evolution in Romania, M. Rădoane and A. Vespremeanu-Stroe, Eds., Springer, 2017, pp. 271-304. doi:10.1007/978-3-319-32589-7_12

[2] D.J. Varnes, "Slope movement types and processes" in Landslides, analysis and control, R.L. Schuster and R.J. Krizek, Eds. Special Report 176: Transportation Research Board. National Academy of Sciences, Washington, DC, pp 11-33, 1978.

[3] O. Hungr, S. Leroueil, and L. Picarelli, "The Varnes classification of landslide types, an update”, Landslides, vol. 11, pp. 167-194, 2014.

[4] R. Dikau and K.-H. Schmidt, "Mass movements in South, West and Central Germany-objectives and main results of the MABIS project”, Z Geomorphol Suppl, vol. 125, pp. 1-12, 2001.

[5] B Damm and B. Terhorst, "A model slope formation related to landslide activity in the Eastern Prealps, Austria”, Geomorphology, vol. 122, pp. 338-350, 2010. 


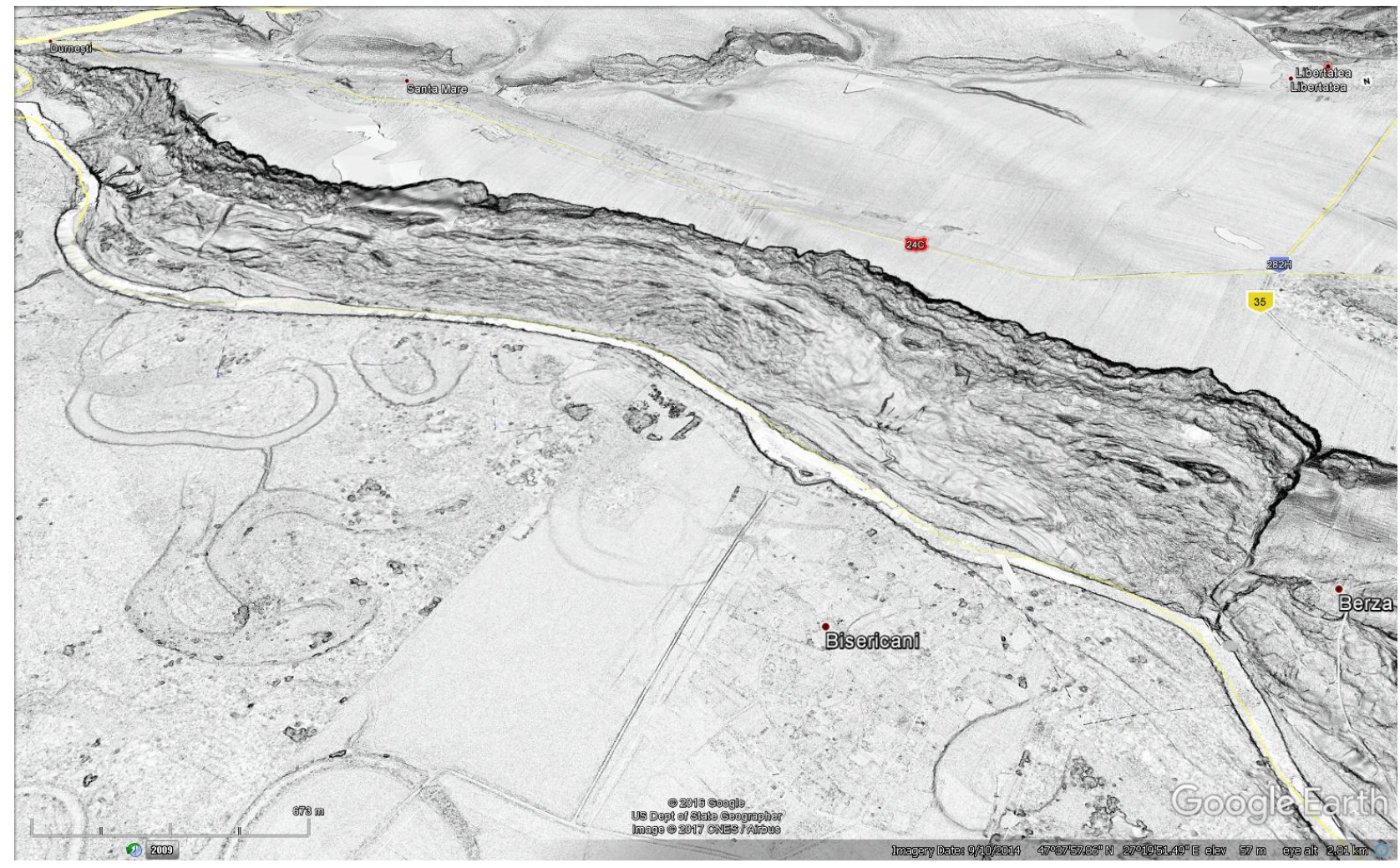

Fig. 1. Perspective view of LiDAR shading for the Santa Mare - Berza complex landslide.

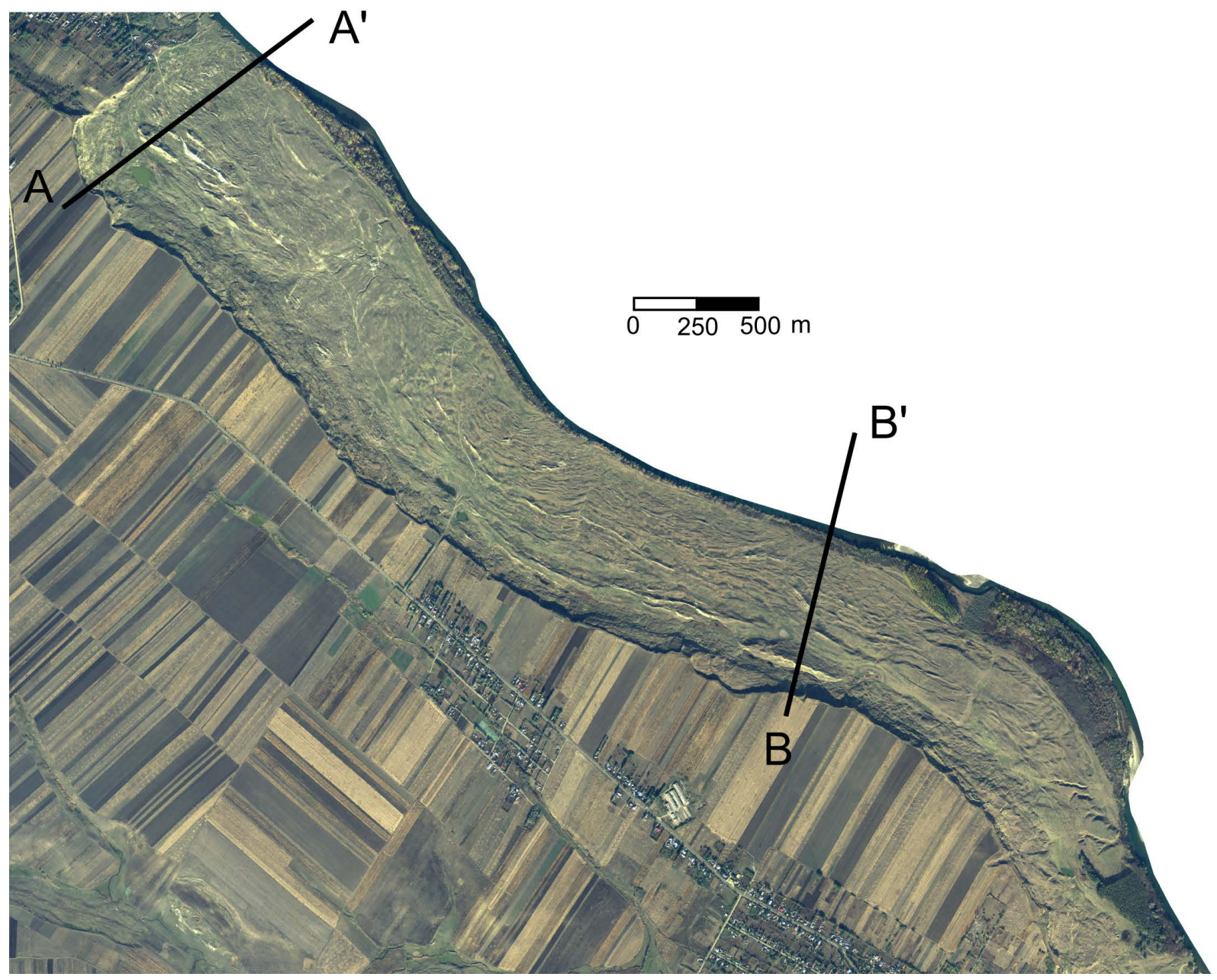

Fig. 2. Aerial image of the Santa Mare - Berza complex landslide (2008) and location of topographic sections from Fig. 3. 


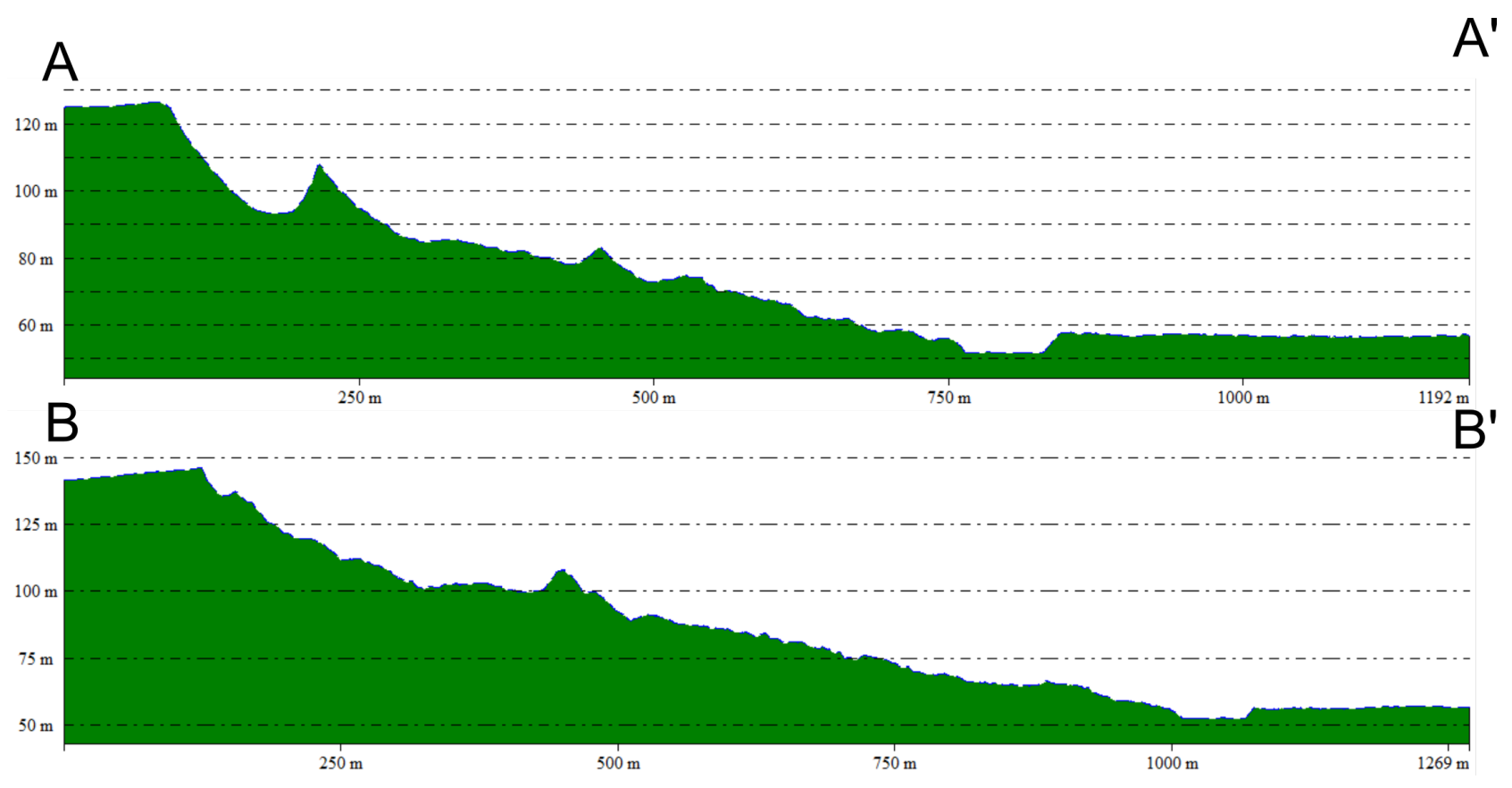

Fig. 3. Topographic sections trough the Santa Mare - Berza complex landslide (for the locations of the sections see Fig. 2). 

Annex: Fieldtrips map

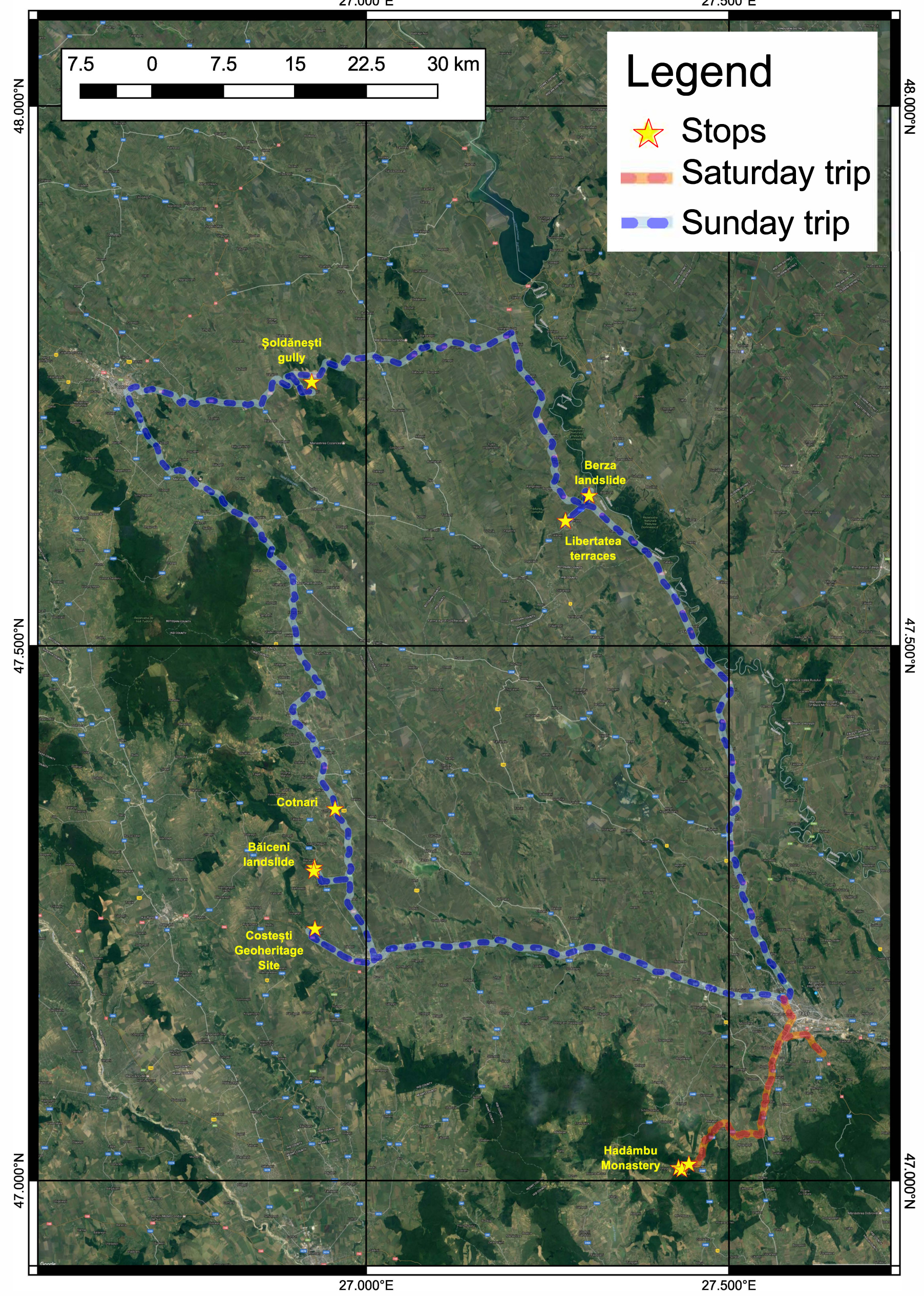




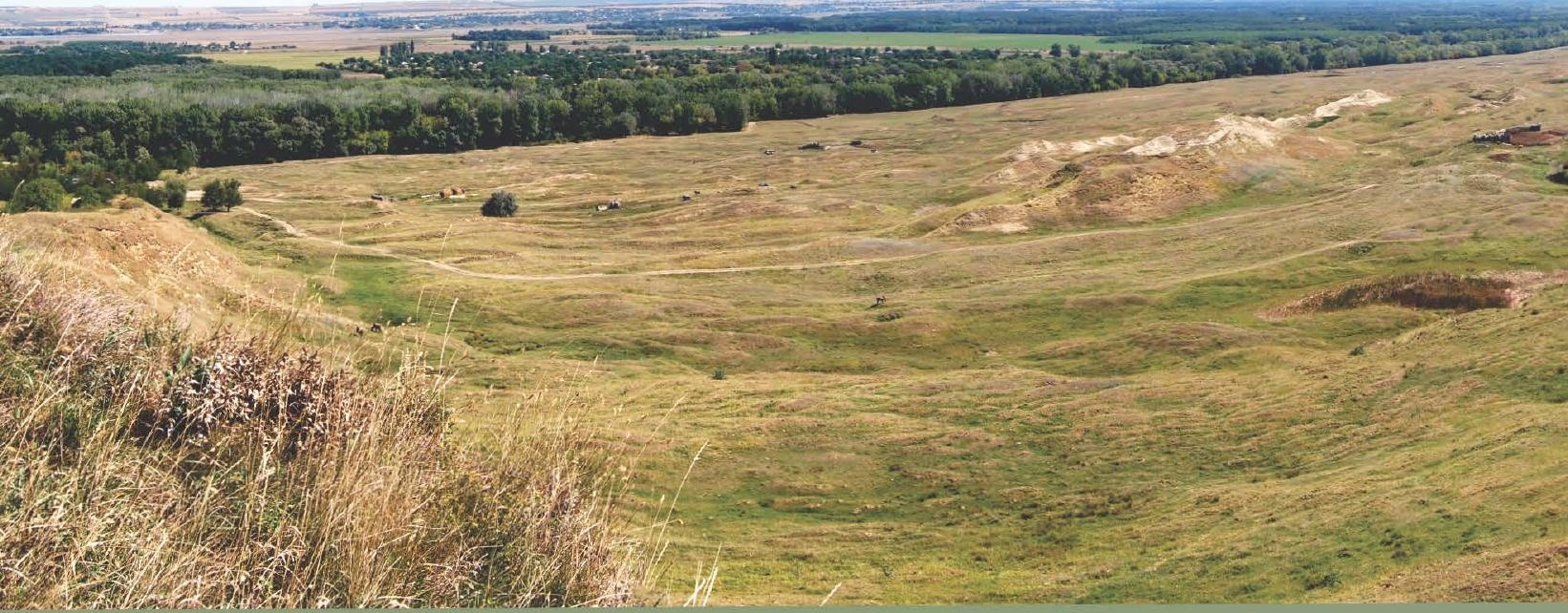

ISSN $2559-3021$

ISSN-L $2559-3021$ 